UNIVERSIDADE DE SÃO PAULO

ESCOLA DE ENFERMAGEM

\title{
O DESENVOLVIMENTO DE COMPETÊNCIAS PARA A DOCÊNCIA \\ SEGUNDO A VIVÊNCIA DE DOCENTES DE UM CURSO DE GRADUAÇÃO
}

EM ENFERMAGEM

INAHIÁ PINHEL 
INAHIÁ PINHEL

\section{O DESENVOLVIMENTO DE COMPETÊNCIAS PARA A DOCÊNCIA SEGUNDO A VIVÊNCIA DE DOCENTES DE UM CURSO DE GRADUAÇÃO}

EM ENFERMAGEM

Tese apresentada ao Programa Interunidades de Pós-Graduação em Enfermagem da Escola de Enfermagem da Universidade de São Paulo, para obtenção do título de Doutor em Enfermagem.

Orientadora: Prof ${ }^{a}$. Dr ${ }^{a}$ Paulina Kurcgant 


\section{Catalogação na Publicação \\ Biblioteca "Wanda de Aguiar Horta" \\ Escola de Enfermagem da Universidade de São Paulo}

Pinhel, Inahiá

O desenvolvimento de competências para a docência segundo a vivência de docentes de um curso de graduação em enfermagem. / Inahiá Pinhel. - São Paulo: I. Pinhel, 2006.

$173 \mathrm{p}$.

Tese (Doutorado) - Programa Interunidades de Doutoramento em Enfermagem dos Campi de São Paulo e Ribeirão Preto da USP.

Orientadora: $\operatorname{Prof}^{\mathrm{a}}$ Dr $^{\mathrm{a}}$ Paulina Kurcgant

1. Ensino Superior (Enfermagem) 2. Competência Profissional

3. Docente em Enfermagem. I.Título. 


\section{RESUMO}

Este estudo versa sobre o desenvolvimento de competências para a docência segundo a vivência de docentes de um curso de graduação em enfermagem. Busca conhecer quando e como docentes de um curso de graduação de Enfermagem desenvolvem competências para a docência; identificar os conhecimentos e as habilidades desenvolvidas pelos docentes na construção de competências para o ensino de Enfermagem e identificar como intervir nesse processo, por meio da reflexão sobre a profissão docente. Realizada com a metodologia da pesquisa-ação, esta pesquisa social, busca a confirmação de 3 hipóteses iniciais formuladas pela pesquisadora, objetivando comprovar se o perfil atual do professor enfatiza as qualidades pessoais que invadem a construção das competências docentes; se este perfil sofre a influência dos valores vigentes na sociedade e se as estruturas das Instituições de Ensino Superior (IES) influenciam e determinam a trajetória e a capacitação profissional do docente. Face às hipóteses e objetivos, a pesquisa foi realizada em dois momentos sucessivos, iniciando com entrevistas individuais com as docentes cujas falas, foram analisadas pelo método da análise de conteúdo, segundo a técnica de análise temática, que conforme Minayo (1996) consiste em descobrir os núcleos de sentido que compõem uma comunicação. Desta análise resultou um relatório síntese, adotado como texto disparador para o momento seguinte, que foi a realização de um grupo focal, constituído por 6 docentes integrantes do corpo docente do curso de Enfermagem, lócus da pesquisa. Os dados coligidos no grupo focal foram analisados conforme a metodologia da hermenêutica dialética, segundo determinantes estruturais, particulares e singulares, sob a ótica do materialismo histórico-dialético, possibilitando captar os sentidos e conceitos dos sujeitos com relação ao tema da pesquisa. Os resultados referendam as hipóteses formuladas e apontam para o estabelecimento de um novo modo de pensar e de agir no contexto da educação em enfermagem, visando a melhoria no atendimento das demandas sociais, referindo-se à construção das competências ético-sociais, envolvendo a capacidade de colaboração e cooperação com o outro (estudantes, usuários, docentes e demais profissionais), estabelecendo relações humanas participativas e construtivas, assumindo a responsabilidade de ser um agente transformador social sob a égide da ética, especialmente a ética no cuidado, respeitando a autonomia, a diversidade e a responsabilidade nas relações com o outro. Estas relações possibilitaram o desenvolvimento de competências da esfera sócioeducativa, envolvendo a comunicação, autonomia intelectual, capacidade auto-reflexiva e de autocrítica. As condições da unidade de ensino proporcionaram o desenvolvimento de competências técnico-científicas, relacionadas à aquisição, construção e domínio dos saberes necessários para a realização das atividades nas áreas da enfermagem e do ensino em enfermagem. As competências docentes não foram construídas em um momento temporal específico, mas sim, ao longo das trajetórias pessoais e profissionais, no cotidiano das docentes, expandido para além da sua área técnica de formação, invadindo os espaços sociais das relações interpessoais, tanto na sociedade, quanto nas instituições de ensino. As falas captadas mostraram grande sintonia na direção de um conjunto de fatores intervenientes, demonstrando a influência do processo histórico e dos determinantes sociais, que por sua vez, moldam as estruturas das unidades de ensino, estabelecendo as relações com as competências. Com relação às habilidades, foram desenvolvidas as referentes às relações interpessoais e de interação professor-aluno; de planejamento das ações e de uso de novas estratégias e metodologias de ensino que possibilitaram o aprimoramento da visão educacional e as voltadas para a construção da autonomia intelectual, tanto do aluno quanto do próprio docente. Para uma nova conformação do processo de ensinoaprendizagem, concluiu-se ser necessário não só aos novos enfermeiros, mas também aos atuais e aos futuros enfermeiros-professores, desenvolverem competências que os possibilitem a pensar e agir com ética e ousadia.

Palavras-chave: Competências docentes; Ensino em Enfermagem; Educação em Enfermagem. 


\begin{abstract}
This study broaches the development of abilities for the teaching following lecturer's experiences with a nursing graduating study. It seeks to know when and how lecturers of nursing graduating colleges develop their teaching abilities; to identify the knowledge and the skills developed by the lecturers in the process of building abilities for Nursing teaching and identify how to interfere in this process, through the reflection over the profession of a teacher. Accomplished with the research-action methodology, this social research, intends to corroborate three initial hypothesis proposed by the researcher, yet intending to confirm if the present profile of a teacher emphasizes the personal qualities that brake in the process of building teaching abilities; if this profile is under the influence of the society's present values and if the structures of the Universities/Colleges (IES) do interfere and determine the professional path and training of the lecturer. In the view of the hypothesis and objectives, the research was made at two successive moments, starting with individual interviews of the teachers whose speech was analyzed through the method of subject analysis, following the technique of thematic analysis, that accordingly with Minayo (1996) consists in finding the signification cores that compose a communication. From this analysis came a synthetic report, adopted as base text for the following moment, which was to build a focal group composed by six lecturers from the teaching staff of a Nursing Graduating course, locus of the research. The data collected in the focal group was analyzed accordingly with the methodology of dialectic hermeneutic, following structural determinants, singular and particular, under the historicdialectic materialism scope, allowing, thus, to collect the subject's senses and concepts related to the research's theme. The results countersign the previous hypothesis and point to the establishment of a new way of thinking and acting in the nursing educational context, intending to improve the assistance to social demands, referring to the process of building ethic-social abilities, involving the capacity of collaboration and cooperation with others (students, users, lecturers and other professionals), establishing constructive and participative human relations, taking the responsibility of being an agent of social transformation, supported by ethics, specially ethics related to the care, respecting the autonomy, the diversity and the responsibility in the relations with others. These relations allowed the development of abilities under the social-educational scope, involving the communication, intellectual autonomy, self reflective and self critical capabilities. The conditions of the educational facility allowed the development of technical-scientific abilities, related to the acquisition, assembling and control of the knowledge needed for the accomplishment of the activities of the nursing educational and practical field. The teaching abilities were not built in a specific temporal moment, but instead, they were built in the course of personal and professional paths, over the teachers daily work, expanding to beyond their formal educational area, trespassing the social fields of interpersonal relations, as much in society, as in the teaching facilities (IES). The speeches recorded have shown great tuning on the direction of a conjunct of intervenient factors, showing the influence of the historical process and the social determinants, those that shape the educational facilities' structures, establishing the relations with the abilities. As for the abilities, those related to interpersonal relations and teacher-student interaction were developed; also, action planning and those related to using new teaching strategies and methodologies that allowed the improvement of the educational view, and those related to building an intellectual autonomy, as much for the student, as for the teacher himself. For a new conformation of the teaching-learning process, we have concluded that it is necessary for the new nurse-teacher, as much as for the present and those yet to come, to develop abilities that allow them to think and act ethically, and with audacity.
\end{abstract}

Keywords: Teaching Abilities; Teaching in nursing; Education in nursing. 
Dedico este trabalho

Aos bravos professores, de todos os tempos. 


\section{Agradecimentos}

À Prof. Dra. Paulina Kurcgant, brava educadora, cujo sopro nos torna leves, permitindo ir além. Obrigada por estar ao meu lado e me conduzir, uma vez mais, a um instante de desenvolvimento profissional e pessoal nesta minha existência.

Aos meus pais Vicente Pinhel e Evanyr Gigliotti Pinhel, exemplos de educadores, pela irradiação de amor e paciência, sempre presentes;

À minha família, pela força e incentivo que sempre me dedicaram;

Ao querido tio Alcy e sua admirável biblioteca que me fez voltar no tempo e compreender tantas coisas;

Ao Rogério, Silvia e Sueli, grandes amigos, que souberam me estender as mãos nos momentos difíceis: minha eterna gratidão;

Ao José Carlos e Gabriela, amigos e companheiros de trabalho, por possibilitar um tempo a mais, tão valioso na realização deste estudo;

Aos amigos Mário, Célia, Marisa e Lígia, cujos laços de amor incondicional os fizeram sempre presentes;

Aos amigos que chegaram para ficar, Poli e Jamil, pelas irradiações de força e vitória;

Aos funcionários da Escola de Enfermagem da Universidade de São Paulo, pelo acolhimento de seus alunos;

À Nê, que acompanhou o desenrolar deste trabalho com suas orações: EU SOU muito grata;

Às professoras que contribuíram neste estudo, com o precioso relato de suas vivências, permitindome a construção dos resultados deste trabalho.

Aos meus alunos, razão de ser, este meu novo caminhar. 


\section{SUMÁRIO}

\section{I- INTRODUÇÃO}

1.1 - A motivação para o estudo

1.2 - 0 objeto do estudo

1.3 - As competências docentes

1.4 - A finalidade da pesquisa

1.5 - Os objetivos do estudo

II - COMPETÊNCIAS E SUA TRAJETÓRIA NA EDUCAÇÃO

III - A TRAJETÓRIA DA EDUCAÇÃO BRASILEIRA 49

IV - A TRAJETÓRIA HISTÓRICA DA EDUCAÇÃO NA ENFERMAGEM

V- PERCURSO METODOLÓGICO

5.1 - A Escolha da Metodologia

5.2 - A Pesquisa-ação 91

5.3 - 0 ambiente da pesquisa

5.3.1 - Breve histórico do ensino católico superior no Brasil 96

5.3.2 - O lócus do estudo 98

5.4 - Os sujeitos da pesquisa 98

5.5 - A preservação dos aspectos éticos da pesquisa $\quad 100$

5.6 - A coleta de dados $\quad 100$

5.7 - A análise dos dados 101

5.7.1 - Análise de conteúdo 101

$\begin{array}{ll}5.7 .2 \text { - Grupo focal } & 104\end{array}$

5.7.3 - Hermenêutica-dialética 106

VI - APRESENTAÇÃO DOS RESULTADOS

6.1 - As entrevistas: a análise de conteúdo 113

6.1.1 - Síntese das entrevistas $\quad 113$

6.1.2 - Relatório Síntese 132

6.2 - 0 grupo focal: a hermenêutica-dialética 134

6.2.1 - A análise das falas: a hermenêutica-dialética 135

6.2.2 - Determinantes estruturais $\quad 139$

6.2.3 - Determinantes particulares 144

6.2.4 - Determinantes singulares 151

VII - ALGUMAS CONCLUSÕES E NOVOS CAMINHOS 161

VIII - REFERÊNCIAS BIBLIOGRÁFICAS 169

ANEXOS 


\section{I - INTRODUÇÃO}

\section{1 - A Motivação para o Estudo}

As considerações sobre o significado "competência" representaram ponto de partida para reflexões ao longo de minha carreira profissional, especialmente com relação ao desafio de refletir sobre o "ser" e o "fazer competente" do professor.

Inicialmente como enfermeira voltada para o cuidado, busquei intensamente, o conhecimento e as habilidades que me tornassem capacitada para o processo de trabalho assistencial e, posteriormente, como gerente de Serviço, procurei ser capaz de gerenciar pessoas. Estes fatos levaram-me a refletir sobre o que julgava "ser uma profissional competente".

Em nova etapa profissional, assumindo o papel de professora de Enfermagem em uma Instituição de Ensino particular, vivenciando o processo de trabalho educacional, vivi um período de adaptação permeado por sentimentos de dúvidas, imobilidade e medos, percebendo melhor o significado de competência que permeava, de forma subjacente, as novas experiências profissionais.

Assim, os questionamentos referentes ao entendimento de como um profissional, com conhecimento em uma determinada área, desenvolvem a capacidade de mobilizar esse conhecimento para a ação, estavam presentes, notadamente, quando assumi a ministração de diferentes disciplinas.

$\mathrm{Na}$ tentativa de desempenhar bem este papel, ferramentas como a reflexão, a auto-avaliação e a disposição para mudança, sempre se mantiveram presentes em minha trajetória profissional. Entretanto, na esfera da Educação assim como em outras, os questionamentos e as reflexões individuais não foram suficientes, obrigando-me ao envolvimento e à troca coletiva com outros docentes em 
discussões que permeavam esse processo de trabalho na busca de respostas mais consensuais.

O corpo docente dos cursos de Enfermagem é, em grande parte, constituído por profissionais oriundos da área assistencial, levados, posteriormente, ao ensino, de maneira similar à minha vida profissional, tendo que enfrentar a nova realidade que se apresenta com situações complexas, sem ter tido, muitas vezes, a oportunidade de desenvolver competências para a docência.

É esta situação específica, ou seja, conhecer como se dá a formação de competências para a docência que nos estimulou a desenvolver a presente pesquisa.

\section{2 - O Objeto de Estudo}

Ora, se é verdade que a boa escola é imprescindível para o desenvolvimento do indivíduo e da sociedade, é certo também que são indispensáveis bons professores, pois sem eles não há escola. A preocupação a respeito de qual a melhor formação para os jovens na sociedade atual, de qual a estrutura mais adequada do sistema de ensino, de qual a ideal relação pedagógica professor/aluno, está diretamente ligada a esta outra questão relativa às competências que deve ter um bom professor. (GOERGEN,1998,p.14)

A sociedade contemporânea, com a velocidade das inovações tecnológicas e mudanças sociais, vem experimentando transformações substanciais no sistema produtivo e conseqüentemente, no perfil comportamental das pessoas.

O sucesso econômico decorrente da primeira revolução Industrial, pautada em abordagens mecanicistas, com a substituição da força física do homem pela energia das máquinas, cedeu espaço para a ocorrência da segunda revolução industrial, agora com ênfase nas capacidades intelectuais e nas chamadas competências humanas.

O resultado da associação entre o desenvolvimento da microeletrônica e a expansão tecnológica e industrial e ainda, entre a química fina, propiciou uma reorganização do mundo produtivo capitalista, que apresenta certas tendências referenciadas como flexibilização da produção e reestruturação das ocupações, interação de setores da produção, multifuncionalidade e polivalência dos trabaIhadores, valorização dos saberes dos trabalhadores não ligados ao trabalho prescrito ou ao conhecimento formalizado (Ramos, 2002). Ademais, foram criadas 
condições para a instalação da chamada "era do conhecimento", tendo como paradigma a valorização da informação, fazendo com que a economia se volte para a busca de profissionais classificados como "competentes", "habilidosos", "criativos" e "portadores de conhecimentos relevantes".

O mundo da educação não se encontra fora deste contexto e sofre reflexos das transformações ocorridas nos processos de trabalho de tal forma que 0 ensino, como atividade profissional, tem se revelado com uma dimensão ampla e complexa, envolvendo articulações com os aspectos políticos, econômicos, sociais, tanto em âmbito local como nacional e internacional.

Os objetivos para esta nova conformação da educação, voltada para a reelaboração dos conhecimentos existentes, para a produção de novos conhecimentos e com a disposição para apreensão das habilidades necessárias, envolvem profundas modificações na interação professor-aluno e ainda, segundo Faria (2003, p.9),

deverão expressar ações como a reflexão crítica, a curiosidade científica, a criatividade e a investigação, tendo por base a realidade dos educandos, tendo um professor a responsabilidade de articular metodologias de ensino caracterizadas por uma variedade de atividades estimuladoras da criatividade dos alunos.

Assim, nestes tempos de profundas transformações, as preocupações dos educadores sobre as questões epistemológicas ligadas à melhoria da formação dos jovens e à estrutura mais adequada do sistema de ensino, além da relação pedagógica professor/aluno desejável, estão diretamente ligadas a outro questionamento fundamental: quais as competências que deve ter um bom professor na atualidade?

Perpassada pelo senso comum, a noção ou o entendimento de competência ${ }^{1}$ é associada ao sucesso, à autoridade de um indivíduo sobre determinado assunto e ainda ao seu "status quo" pessoal ou na sociedade onde está inserido. Inicialmente, subjacente ao processo cultural, econômico e principalmente político somente mais recentemente, explicitada e merecedora de estudos mais aprofundados, competência passou a ser compreendida como um conceito que permeia o processo educacional como um todo, passando a ter grande influência sobre o papel profissional docente.

\footnotetext{
${ }^{1}$ Derivando do latim competentia, etimologicamente competência possui vários significados, entre os quais a faculdade concedida por lei a um funcionário, juiz ou tribunal para apreciar e julgar certos pleitos ou questões (...) qualidade de quem é capaz de apreciar e resolver certo assunto, fazer determinada coisa; capacidade, habilidade, aptidão, idoneidade; (...) conhecimento lingüístico, parcialmente inato e parcialmente adquirido, que permite a um indivíduo falar e compreender a sua língua. Cf. Ferreira (2001)
} 
O termo competência vem sendo enfaticamente empregado no intuito de associar o conhecimento teórico à prática, tendo como centro, o indivíduo capaz de tal realização, ou seja, o professor, que articula os "saberes docentes" e suas competências, em um processo de desenvolvimento pessoal e profissional, tendo como pano de fundo as conformações sócio-econômicas e culturais.

Zarifian (1999) apud Ramos (2002, p.66), entende que competência seja a "capacidade que os trabalhadores têm de enfrentar situações e acontecimentos próprios de um campo profissional, com iniciativa e responsabilidade, guiados por uma inteligência prática que está ocorrendo e coordenando-se com outros atores para mobilizar suas próprias capacidades", relacionando-a portanto, à interação social e ao caráter coletivo da sua esfera de ação.

$\mathrm{Na}$ esfera educacional, conforme Perrenoud (2002,p.32), a competência requerida na atualidade é

o domínio dos conteúdos com suficiente fluência e distância para construí-los em situações abertas e tarefas complexas, aproveitando ocasiões, partindo dos interesses dos alunos, explorando os acontecimentos, em suma, favorecendo a apropriação ativa e a transferência dos saberes, sem passar necessariamente por sua exposição metódica, na ordem proposta por um sumário.

Morin, Kern (1993) reconhecem a complexidade da atividade docente e pregam a construção de competências, que transcendem o conceito cartesiano aquisição de habilidades ou de simples desenvolvimento de conhecimentos técnicos, que repercutem apenas na generalização do trabalho parcelar sem iniciativa, sem responsabilidade e sem interesse.

Parafraseando Paulo Freire (1983), a educação somente é possível para o homem "porque este é inacabado e sabe-se inacabado, portanto, implica uma busca realizada por um sujeito - o próprio homem, que não pode ser objeto dela e sim o sujeito da sua própria educação".

Assim, a educação é um sistemático e intencional processo de interação com a realidade por meio do relacionamento humano baseado no trabalho com 0 conhecimento, realizado sob a mediação do professor, com a finalidade de colaborar com a formação do estudante em sua totalidade. $O$ docente, a partir e com a utilização de suas competências, conforme Vasconcellos (2001, p.51) busca

\footnotetext{
${ }^{2}$ Pode-se definir saber docente como um saber plural, formado pelo amálgama, mais ou menos coerente, de saberes oriundos da formação profissional e de saberes disciplinares, curriculares e experienciais. Cf. Tardif (2002).
} 
proporcionar condições que possibilitem a produção de sentido, que é uma construção do sujeito da ação pedagógica: o estudante.

A produção do sentido não é uma construção isolada, é uma produção histórica realizada em um contexto histórico e coletivo, a partir das "relações que se dão não apenas com os outros, mas se dão no mundo, com o mundo e pelo mundo" (FREIRE, 1983, p.30).

O professor, ao se entender como parceiro privilegiado neste processo de criação e transformação, trabalha com as relações que o sujeito (aluno) faz com o objeto (ou situação) e com sua existência, tanto passada (experiências, representações prévias), quanto presente (situação de conhecimento) e futura (expectativas, desejos e aspirações), conforme Vasconcellos (2001, p.51), que afirma ainda:

Ser professor, na acepção mais genuína, é ser capaz de fazer o outro aprender, se desenvolver criticamente. Como a aprendizagem é um processo ativo, não vai se dar, portanto, se não houver articulação da proposta de trabalho com a existência do aluno, mas também do professor, pois se não estiver acreditando, se não estiver vendo sentido naquilo, como poderá provocar no aluno o desejo de conhecer?

Pela legislação vigente, o ensino superior no Brasil é regulado pela Lei de Diretrizes e Bases $^{3}$, sendo a autorização de funcionamento dos cursos realizada a partir de Resoluções da Câmara de Educação Superior do Conselho Nacional de Educação contendo as Diretrizes Curriculares Nacionais - DCN, especificamente para cada carreira profissional.

Estes documentos recomendam os elementos de fundamentação essencial em cada área do saber ou profissão, com o objetivo de desenvolver, no estudante, a competência do processo intelectual e profissional autônomo e duradouro, permitindo a continuidade do processo de formação acadêmica e/ou profissional.

Na área do ensino de Enfermagem, a Resolução no 03/2001 cita, em vários trechos de seus itens, a formação geral e especifica dos egressos / profissionais e tem por objetivo, dotar o profissional de conhecimentos para o exercício das competências e habilidades específicas, estabelecendo que o perfil do formando deve ter como base, uma formação generalista, humanista, crítica e reflexiva. Nas competências e habilidades previstas, identifica-se a proposta de que,

\footnotetext{
${ }^{3}$ Lei no 9.394 de 20/12/1996.

${ }^{4}$ Resolução CNE/CNS n 03 de 7 de Novembro de 2001, publicada no Diário Oficial da União - DOU em 9/11/2001, Seção I,p.37, em atendimento ao disposto na Lei no 9.394 de 20/12/1996 (Lei de Diretrizes e Bases - LDB). (ANEXO 6).
} 
para a atenção à saúde, o profissional deve estar apto a utilizar estratégias como tomada de decisão, comunicação, liderança, instrumentos administrativos e de educação permanente, como meios para o gerenciamento dos processos de trabalho em enfermagem, devendo ainda, possuir competências e habilidades específicas na dimensão técnico-científica, ético-política e sócio-educativa, atendendo às necessidades de saúde, com ênfase no Sistema Único de Saúde (SUS), assegurando a integralidade da atenção e a qualidade e humanização do atendimento.

As enfáticas referências às competências e habilidades apresentadas nas recomendações e itens da Resolução CNE/CNE no 03/2001, nos levam a entender ser relevante a compreensão e apreensão do conceito de competência docente por parte dos enfermeiros que exercem estas funções, em função da sua implicação na formação dos futuros profissionais de enfermagem.

\section{3 - As competências docentes}

Por ser um conceito polissêmico, tanto na esfera do trabalho quanto na da educação, competência tem vários significados, entre os quais a qualidade de quem é capaz de apreciar e resolver certo assunto, de fazer determinada coisa ou possuir uma capacidade, habilidade ou aptidão, ou seja, de maneira geral, a noção de competência se apresenta sempre associada a ação.

É importante destacar que a noção de competência não é nova, mas seu uso tem sido difundido nos discursos sociais e científicos mais recentemente, tendo sido apropriado pelo mundo do trabalho, que o relaciona ao conceito de qualidade. Por estar relacionado à ação, o conceito de competência deve ser avaliado em função de uma determinada situação posta, pois, conforme Stroobants (2002, p.39),

\footnotetext{
A palavra competência é, aliás, bem mais rica do que o uso que dela se faz atualmente, já que designa simultaneamente o direito e a capacidade de conhecer. Para conhecer os meios de compreender a maneira como as competências se diferenciam, é necessário considerá-las como produtos de processos e não mais como pontos de partida, encarando esses processos como seqüências de "habilitações". Será competente aquele que está habilitado a tornar-se hábil em um domínio de conhecimento.
}

Para Ferreti (1997) apud Ramos (2002, p.40) segundo a lógica capitalista, a noção de competência representa apenas uma atualização do conceito de quali- 
ficação, enquanto para Frigotto (1995) apud Ramos (2002, p.40), o conceito pode representar o rejuvenescimento da "teoria do capital humano" e uma metamorfose do conceito da qualificação na sua conotação produtivista, ou seja, voltado para a elevação da exploração do trabalhador por parte do capital.

Por outro lado, Ramos (2002) defende a tese que a noção de competência seja definida como sendo um deslocamento conceitual da qualificação à competência. Para tanto, toma a qualificação como conceito central na relação trabaIho-educação e discute o conceito de competência como mais objetivo por ter ordenado, historicamente, as relações sociais de trabalho e educativas, frente à materialidade do mundo produtivo. Segundo a autora,

\begin{abstract}
essa centralidade tende a ser ocupada, contemporaneamente, não mais pelo conceito de qualificação, mas pela noção de competência que, aos poucos constitui-se como conceito socialmente concreto. Não obstante, a noção de competência não substitui ou supera o conceito de qualificação. Antes, ela o nega e o afirma simultaneamente, por negar algumas de suas dimensões e afirmar outras. (op.cit., p.41)
\end{abstract}

Referindo-se ao mundo do trabalho, a autora analisa que a dimensão conceitual da qualificação se remete à formação e ao diploma, frequentemente perseguido como interface entre a formação e o emprego, na acepção que este garantiria uma qualificação, um status, uma remuneração. Mas, questiona, isto garantiria a competência?

Segundo ela, o exercício da competência não existe sem que haja profundidade dos conhecimentos que possam ser disponibilizados e mobilizados pelo sujeito para superar determinada situação. Os conhecimentos e saberes não se limitam ao nível de sua aplicabilidade, mas, justamente porque implicam em um exercício reflexivo, pressupõe-se que o sujeito mobilize o conjunto de valores, aprendizagens e habilidades em favor das situações. Assim, entende a autora,

conquanto a qualificação remeta-se ao homem em suas condições históricas de produção da existência, construindo-se como conceito históricoconcreto de mediação da relação trabalho-educação, a competência, por abstrair essas múltiplas determinações da atividade humana, pode resgatar uma compreensão essencialista do trabalho, cujo centro, ao invés de ser o posto de trabalho, desloca-se para o sujeito abstraído das relações sociais. (op.cit:;68)

Por sua vez, Berger (1998, p.8; 2000, p.5) afirma entender por competência, cognitivo, sócio-afetivo ou psicomotor que, mobilizadas e associadas a 
saberes teóricos ou experiências, geram habilidades, ou seja, um saberfazer.

Na mesma direção, documento do Ministério da Educação e Cultura (Brasil, MEC; 2000) define competências como sendo

as modalidades estruturais de inteligência, ou melhor, as ações e operações que utilizamos para estabelecer relações com e entre objetos, situações, fenômenos e pessoas que desejamos conhecer. As habilidades decorrem das competências adquiridas e referem-se ao plano imediato do 'saber-fazer'. Por meio das ações e operações, as habilidades aperfeiçoam-se e articulam-se, possibilitando nova reorganização das competências.

Conforme Ramos (2002, p.182), em termos dos conteúdos concretos do trabalho, Zafirian (1999) identifica a competência de processo (relativa ao deslocamento da atenção do trabalhador da conduta individual das máquinas, para os processos de trabalho), a competência técnico-performativa (relativa ao desenvolvimento de uma visão de gestão do trabalho), a competência sobre a organização (que possibilita e é resultante da anterior, permitindo a reelaboração de objetivos a partir de parâmetros e princípios da organização produtiva), a competência de serviço (implica o trabalhador perguntar-se sobre os impactos provocados direta ou indiretamente por seus atos profissionais nas vidas dos usuários, ou a utilidade dos serviços para os usuários finais) e a competência social (saber-ser ou comportamentos e atitudes do trabalhador, sua autonomia, responsabilidade e capacidade de comunicação com o ambiente social)

Por sua vez, Bunk (1994) apud Ramos (2002, p.187), apresenta o conceito de competência de ação, que seria composta pela competência técnica (domínio de conhecimentos e destrezas necessários para a realização eficiente e profissional de tarefas em uma área de trabalho), a competência metódica (relacionada à capacidade de reação adequada face à tarefas laborais e desvios surgidos, descobrindo autonomamente as vias de solução, transferindo de forma sensata as experiências colhidas para outros problemas de trabalho), a competência social (envolve a colaboração e cooperação com outras pessoas, referindo às relações humanas), a competência participativa (relacionada à co-organização do trabalho de forma construtiva do trabalho e do ambiente de trabalho, capacidade de organizar e decidir de forma atuante, assumindo responsabilidades).

Ainda segundo Ramos (2002, p.187), Valle (1999) entende competência como "uma forma de interpretar o mundo", classificando-a em três dimensões: competências técnicas (que permitem interpretar os processos físicos e organiza- 
cionais), competências subjetivas (que permitem interpretar as relações pessoais e interpessoais) e as competências sociais (que permitem interpretar o que ocorre no mercado, no espaço público).

No ambiente da educação, Perrenoud (1999, p.8; 2000, p.15) refere competência docente como sendo uma "capacidade de agir eficazmente em um determinado tipo de situação, apoiada em conhecimentos, mas sem limitar-se a eles," possibilitando que o professor ponha "em ação e em sinergia, vários recursos cognitivos complementares, entre os quais estão os conhecimentos." Segundo o autor complementa, é a competência docente que permite ao professor enfrentar um ou mais tipos de situações, realizando operações mentais complexas voltadas para a determinação e realização de uma ação relativamente adaptada para a situação vivenciada.

Sob esta ótica, a competência docente está associada não apenas aos saberes (conhecimentos) que o professor precisa ter, mas também intimamente ligada às capacidades e habilidades que, em situações complexas e principalmente em tempo real, permitem eclodir esquemas de pensamento que possibilitem a mobilização, a orquestração e a sistematização de recursos pertinentes para a aplicação destes saberes, lembrando que, conforme Tardif $(2002$, p.18) afirma,

o saber dos professores é plural, composto e heterogêneo, porque envolve, no próprio exercício do trabalho, conhecimentos e um saber-fazer bastante diversos, provenientes de fontes variáveis e, provavelmente, de natureza diferente.

Assim, com base nos pressupostos e conceitos dos autores visitados, depreende-se que competência docente é uma categoria complexa de atividades mental e intelectual que reúne a capacidade e a habilidade do educador em mobilizar conhecimentos e recursos para resolver situações complexas em tempo real, isto é, que ocorrem, a cada momento, na vida profissional. 


\section{4 - A finalidade da pesquisa}

O percurso histórico do ensino em Enfermagem indica o comprometimento, especialmente dos seus docentes, na formação de futuros profissionais, observando-se que o processo evolutivo da profissão enfermagem no Brasil vem sendo dirigido pelas escolas e pelos modelos de currículo mínimo obrigatório, este legalmente determinado. A evolução do currículo para o preparo de enfermeiros, segundo Saupe (1998), "inicia-se com um enfoque generalista e comunitário e vai se adaptando às políticas de saúde emergentes e ao modelo de privatização dos serviços de saúde."

Nimtz (2003) entende que, paralelamente à regulamentação da profissão e ao estabelecimento do currículo que norteia a formação do enfermeiro, estão as questões relacionadas à capacitação pedagógica dos docentes de enfermagem, constituindo-se uma situação inquietante, na medida em que o crescimento significativo dos cursos de graduação em enfermagem provocou a transformação de profissionais de enfermagem em docentes destes cursos, muitos dos quais sem qualquer tipo de preparo para esta atividade.

Diante do cenário decorrente do avanço tecnológico da comunicação e do novo mapa do mundo, frente à globalização, o profissionalismo deixa de ser um diferencial competitivo e passa a ser uma questão de sobrevivência, exigindo que o docente se volte, cada vez mais, para o desenvolvimento de competências, pois na atual sociedade da informação, conforme Shinyashiki (1997), ao mesmo tempo em que a tecnologia elimina muitos empregos, os postos remanescentes e os criados demandam cada vez mais profissionais dotados de competências, habilidades e conhecimentos.

A volatilidade dos conhecimentos resulta em que muitas profissões passam por uma crise crescente no que se refere à confiança, pois muitos profissionais são chamados a desempenhar tarefas para as quais não foram capacitados. O corpo de conhecimentos que o profissional adquire, não está associado ao conhecimento profissional com características próprias de situações da prática, tanto profissional quanto docente, ou seja, com situações que geram instabilidade, complexidade, incerteza, conflito de valores, observando que estas características não são resolvidas com o emprego de conhecimentos especializados e de tarefas bem definidas. 
Diante do exposto, foram delineadas as hipóteses ${ }^{5}$ que fundamentam este estudo, as quais, conforme Minayo (1996) representam afirmações provisórias a respeito de determinado fenômeno em estudo, servindo de caminho e balizas no confronto com a realidade empírica:

- O perfil atual do professor enfatiza as qualidades pessoais que invadem a construção das competências docentes.

- O perfil do professor sofre influência dos valores vigentes na sociedade.

- As estruturas das Instituições de Ensino Superior (IES) influenciam e determinam a trajetória e a capacitação profissional do docente.

Estas razões e hipóteses levaram-me a realizar a presente pesquisa, voltada para o entendimento do processo de construção de competências dos docentes dos cursos de graduação em Enfermagem.

\section{5 - Os objetivos do estudo}

Esta pesquisa tem como objetivos:

- Conhecer quando e como os docentes do ensino superior de Enfermagem desenvolvem competências para a docência;

- Identificar os conhecimentos e as habilidades que foram desenvolvidas, pelos docentes, na construção de competências para o ensino de Enfermagem;

- Intervir nesse processo, por meio da reflexão sobre a prática docente, por eles explicitada.

\footnotetext{
${ }^{5}$ Hipótese é uma proposição que se admite a priori, independentemente do fato de ser verdadeira ou falsa, mas unicamente a título de um princípio a partir do qual se pode deduzir um determinado conjunto de conseqüências, ou seja, trata-se de uma suposição ou uma conjectura, pela qual a imaginação antecipa o conhecimento, com o fim de explicar ou prever a possível realização de um fato e deduzir-lhe as conseqüências. Sob a ótica filosófica, hipótese é entendida como uma proposição (ou conjunto de proposições) antecipada provisoriamente como explicação de fatos, fenômenos naturais, e que deve ser ulteriormente verificada pela dedução ou pela experiência, com vasta explicação científica, metódica e organizada, mas ainda não provada.
} 



\section{II - COMPETÊNCIAS E SUA TRAJETÓRIA NA EDUCAÇÃO}

Partindo do pressuposto que competência é um conjunto de características do professor, a busca do significado de competência de professores universitários conduz, necessariamente, a uma revisão histórica do processo educacional para resgate da importância deste conceito ${ }^{6}$. Como sabemos, a prática da educação é antiga e anterior ao próprio pensamento pedagógico, pois este surge como necessidade de sistematização a partir de reflexões sobre a prática educacional.

Considerando a natureza social do homem, a educação primitiva era marcada por rituais de iniciação, sendo, portanto de natureza prática, baseada na imitação e oralidade, fundamentada na visão animista cuja crença consistia no fato que todas as coisas possuíam uma alma, semelhante à do homem.

Segundo Gadotti (1999), educar na comunidade primitiva era tarefa confiada à toda comunidade, em função da vida para a vida, onde o aprender era ação, ou seja, para a criança aprender a usar o arco, caçava. Assim, os conhecimentos foram sendo transmitidos de geração em geração, em um processo histórico e cultural, sem que haja, neste estágio de desenvolvimento, comprovação da existência ou referência às competências, apenas às habilidades de enfrentamento do homem com relação às forças da natureza.

A educação, considerada um legado cultural de um povo, passou aos poucos das mãos da família para fora dela na medida em que as sociedades foram se tornando mais complexas. O ensino doméstico, no qual muitas vezes os fiIhos recebiam dos pais os segredos de um ofício, foi gradativamente, sendo substituído pela universalização e formalização do ensino laico.

Este movimento possibilitou o surgimento da função do professor que, com o passar dos séculos se tornaria, cada vez mais, diretamente responsável

\footnotetext{
${ }^{6}$ Conforme proposto inicialmente, nosso estudo está relacionado com professores do curso de graduação em Enfermagem de uma IES localizada no interior do Estado de São Paulo.
} 
pela educação formal das gerações mais jovens, observando-se, ainda, o distanciamento mantido pelo Estado com relação a estas funções, adstritas ainda ao âmbito familiar.

Em quase todas as civilizações marcadas pela influência religiosa, os professores eram sacerdotes que também transmitiam a essência da cultura local, e segundo também Gadotti (1999, p.23),

\begin{abstract}
A educação primitiva era única, igual para todos; com a divisão social do trabalho aparece também a desigualdade das educações: uma para os exploradores e outra para os explorados, uma parte para os ricos e outra para os pobres [...] A educação sistemática surgiu no momento em que a educação primitiva foi perdendo pouco a pouco o seu caráter unitário e integral entre a formação e a vida, o ensino e a comunidade.
\end{abstract}

No Oriente, o Taoísmo é considerado a doutrina pedagógica mais antiga, (seguida pelo budismo, hinduísmo e o judaísmo), estabelecendo como princípios básicos uma vida pacífica, tranqüila, firmados em valores da tradição, da nãoviolência, ligando-se à religião, e tendo como mentor Lao Tsé que viveu por volta do século VI a.C.

Com base nos princípios do Taoísmo, Confúcio (551 - 479 a.C.) estabeleceu um sistema moral que exaltava a tradição e o culto aos mortos, logo transformado em religião do Estado, situação em que se manteve na China até a Revolução Cultural, promovida por Mao Tsé Tung no final do século XX.

No confucionismo, continua Gadotti (1999), a educação chinesa tradicional visava reproduzir o sistema de hierarquia, obediência e subserviência ao poder dos mandarins. No entanto, conforme Hubert (1967, p.187), "o ensino de Confúcio dirige-se precisamente ao Príncipe ou aos detentores de autoridade, e de modo nenhum às massas ou ao ser humano em geral".

Ainda para este autor, a irradiação da personalidade de Confúcio se deve mais a uma fé nas virtudes humanas, na firmeza de vontade, na vivacidade dos sentimentos e acima de tudo, na força de seu apego às tradições e às velhas virtudes da China do que propriamente à sua excepcional capacidade dialética.

Já no mundo ocidental, continua Hubert (op.cit.), a prática educativa considerada mais antiga, vem da Grécia Antiga, e remonta a mais de 2.500 anos, observando-se também que a pedagogia nasceu na Grécia simultaneamente ao mundo oriental, como aspecto essencial da filosofia. A posição geográfica da Grécia facilitava o comércio entre o Oriente e Ocidente, servindo de berço para a cultura, a civilização e a educação ocidental. Com uma visão universal e questio- 
namentos sobre "o que é o homem", os gregos iniciaram a formulação do pensamento filosófico.

Tentando responder às questões filosóficas surgidas, duas importantes cidades gregas - Esparta e Atenas iniciaram uma rivalidade. Por um lado, os espartanos acreditavam que o homem deveria ser em primeiro lugar, o resultado de seu culto ao corpo e, portanto, ser forte, desenvolvido em todos os sentidos e eficaz em todas as suas ações. Já para os atenienses, a virtude principal do homem deveria ser a luta por sua liberdade e para isto precisava ser racional, falar bem, saber argumentar e defender seus direitos, ou seja, o ideal de homem educado era o orador.

Entretanto, estes ideais circulavam apenas entre os homens livres, aqueles que não tinham problemas de ordem material, com o comércio ou com as guerras, sendo, portanto, um privilégio de poucos, havendo um homem livre para cada dezessete escravos. A marca da educação grega residia na importância de que o ensino estimulasse a competição e as virtudes guerreiras, para assegurar a supremacia militar sobre as classes dominadas e sobre as regiões conquistadas. Uns poucos eram ensinados a governar e o homem bem educado tinha que ser capaz de mandar e de ser obedecido, demonstrando que a liberdade e a igualdade ainda não eram conceitos concretos, pois a liberdade de ensino e o diálogo existiam somente entre os homens livres e assim,

a educação do homem integral consistia na formação do corpo pela ginástica, na da mente pela filosofia e pelas ciências, e na moral e dos sentimentos pela música e pelas artes. Gadotti (1999, p.30)

Nesta época, o ensino era dividido em três etapas, sendo os ensinamentos da escola primária compostos da leitura do alfabeto, a escrita e a contagem. Os estudos secundários consistiam na educação física, na educação artística, nos estudos literários (estudo das obras clássicas, gramática e redação) e científicos, estes englobando a matemática, a geometria, a aritmética e a astronomia. $O$ ensino superior concentrava-se no estudo da retórica e da filosofia, não sendo incluída a formação para o trabalho na cultura aristocrática grega.

A cultura grega teve enorme contribuição para a educação, a partir da influência de seus eminentes filósofos, especialmente Sócrates (470-399 a.C.). O mundo ocidental permaneceu fiel até os dias de hoje, à importância que Sócrates deu ao conhecimento e à cultura do espírito, sendo considerado o educador do 
Ocidente. Para Hubert (1967, p.196), Sócrates propôs uma doutrina, compreendendo três pontos fundamentais:

\begin{abstract}
Sócrates descobriu o conceito; empregou sua invenção, qual nova chave, para abrir os mistérios da ação moral; no júbilo da descoberta, empreendeu comunicá-la a todos os homens, pois cuidava fosse de sua essência o valer para todos. E é por isso que ela está na origem do universalismo espiritual, e tem alcance pedagógico, social, humano, acima de qualquer medida.
\end{abstract}

Para Sócrates, a função do ser consciente é conhecer-se a si mesmo. A conclusão suprema, ou seja, desenvolver esta função está na arte de compreender e associar, corretamente, os conceitos na formação do juízo e no desenvolvimento da inteligência reflexiva.

Esta é, sem dúvida, uma das primeiras referências sobre uma das competências fundamentais da atividade docente, que é a produção de sentido, na medida em que ajuda o aprendiz ter acesso à cultura, desenvolver sua capacidade reflexiva, estimulá-lo à criação e ao desenvolvimento da consciência do "ser", conforme Vasconcelos (2001, p.50). Nesta direção, continua o autor, o professor desempenha papel decisivo no estabelecimento da competência relacional entre o objeto (ou situação) com a existência, tanto passada (experiências, representações prévias), quanto presente (situação do conhecimento) e futura (aspirações, desejos, expectativas) dos alunos com os quais trabalha.

Para Platão (428-347 a.C.), discípulo de Sócrates, a única coisa que o homem pode levar para a eternidade é a educação e esta só é possível com o cumprimento da tarefa que consiste em

retirar o olho do espírito enterrado no grosseiro pantanal do mundo aparente, em constante mutação, e fazê-lo olhar para a luz do verdadeiro ser, do divino; passar gradativamente da percepção ilusória dos sentidos para a contemplação da realidade pura e sem falsidade. Gadotti (1999, p.35)

Aristóteles (384-322 a.C.), eminente filósofo, foi discípulo de Platão e é considerado o criador do pensamento lógico, acreditava que as idéias estavam nas coisas mesmas, ou seja, na sua própria essência, e o fazia de forma realista assim como realista era a sua concepção educacional, quando considerava que o desenvolvimento espiritual do homem se constitui em três fatores determinantes: disposição inata, hábito e ensino. Assim, o homem torna-se propício às medidas educacionais condicionantes, podendo tornar-se o ser mais distinto ou podendo 
tornar-se o pior de todos; o ser humano aprende fazendo e se torna correto, agindo corretamente.

É importante destacar os fatores apontados como a disposição inata, também denominada de motivação, que pode ser compreendida como a propensão "natural do ser humano em envolver seu interesse individual e exercitar suas capacidades, buscando e alcançando desafios ótimos, sendo importante propulsor da aprendizagem, adaptação e crescimento nas competências que caracterizam o desenvolvimento humano." (GUIMARÃES, 2001, p.37)

No entanto, embora forte e persistente, essa orientação motivacional é muito vulnerável às forças ambientais, razão pela qual emerge o fator representado pelo hábito, ou seja, é necessário que haja a exercitação constante de uma determinada competência para que o hábito se estabeleça e seja introjetada pelo indivíduo, e o envolvimento em uma atividade, por razões intrínsecas, gera maior satisfação, possibilitando facilitar a aprendizagem e o desempenho. Para tanto, 0 indivíduo deve ser estimulado por meio do ensino, a desenvolver, continuadamente, suas competências, demonstrando que segundo Aristóteles, a atividade fundamental da alma é teorética ${ }^{7}$ e $\operatorname{cog}$ oscitiva ${ }^{8}$, dependendo da prática ativa, privilegiando a educação e o ensino como sendo fundamentais para o desenvolvimento.

Já em Roma, a educação romana em época arcaica era reduzida à simples transferência de técnicas tradicionais necessárias à prática da agricultura e ao ofício das armas, embora se ensinasse à criança ler, escrever e contar, sendo considerada inferior à helênica, uma vez que eminentemente reprodutivista e utilitarista em sua essência. Nesta época, apenas os filhos das famílias nobres eram instruídos nos assuntos de guerra, na agricultura e na política, também ressaltando os aspectos das divisões das castas.

A cultura não foi o foco de interesse em Roma até meados do Século III quando, tendo dominado especialmente a região helenizada da Península Itálica, estando o império romano já no caminho das novas conquistas territoriais, percebeu-se que algo faltava à sua glória que a igualasse aos povos que vencera nesse domínio. Hubert (1967) refere que como resposta a esta evidência, os conquistadores começaram a admitir a escola desses povos, devendo-se a expansão do

\footnotetext{
${ }^{7}$ que envolve o hábito de contemplar e desenvolve raciocínio especulativo [N.A.]

${ }^{8}$ que tem o poder ou a capacidade de conhecer. [N.A.]
} 
ensino romano à vinda de professores gregos para Roma e às necessidades de uma sociedade opulenta e refinada.

A partir de então, os estudos romanos passaram a ser essencialmente humanistas e pretendiam universalizar a sua humanitas (cultura geral que transcende os interesses locais e nacionais), sendo este objetivo atingido, posteriormente, com o advento do cristianismo. Pode ser notado que os conceitos fundamentais do pensamento aristotélico e da cultura helênica foram absorvidos e praticados na forma estabelecida no ensino romano, no qual, segundo Gadotti (1999, p.42),

A humanitas era dada na escola do "gramático" que seguia as seguintes fases:

- ditado de um fragmento do texto, a título de exercício ortográfico;

- memorização do fragmento;

- tradução do verso em prosa e vice-versa;

- expressão de uma mesma idéia em diversas construções;

- análise das palavras e frases;

- composição literária.

O sistema de ensino representou um fator decisivo para a completa dominação dos povos dos novos territórios anexados ao Império Romano, razão pela qual o latim sendo imposto às províncias conquistadas pelos romanos, observando-se que novamente, estes ensinamentos eram direcionados para as elites romanas, permanecendo os escravos sem instrução e responsáveis pela produção material da existência das elites. Em sua época áurea, Roma possuía um sistema de educação com três graus de ensino: escolas que ministravam a educação elementar, denominadas ludi-magister; escolas do gramático, que correspondiam ao ensino secundário de hoje, e os estabelecimentos de ensino superior, nos quais eram iniciados os ensinos da retórica, seguidos do Direito e da Filosofia.

A enorme extensão do império requeria escolas que preparassem administradores, uma vez que os soldados eram preparados nas batalhas e nos numerosos quartéis. Desta maneira, pela primeira vez na história, o Estado assumia a educação, montando sua própria estrutura. Foram treinados para vigiar as escolas os supervisores-professores, cujo regimento era similar ao dos militares, que ensinavam, segundo Gadotti (1999, p.44),

Direitos e deveres, eis o que ensinavam os romanos:

- direito do pai sobre os filhos (pater potestas)

- direito do marido sobre a esposa (manus)

- direito do senhor sobre os escravos (potestas dominica)

- direito de um homem livre sobre um outro que a lei lhe dava por contrato ou por condenação judiciária (manus capere) 
- direito sobre a propriedade (dominium).

Os deveres decorriam desses direitos (...), a educação romana era utilitária e militarista, organizada pela disciplina e justiça.

Pelo poder de dominação e conseqüente subalternidade, o império romano foi conservado por muitos anos, fenômeno este chamado de "romanização", cuja obra foi terminada pelo cristianismo nos anos seguintes (id.ibid).

O que vimos até aqui, foi um movimento histórico permeado por influências culturais, de dominação e de poder político que parecem ser o pano de fundo no desenrolar da história. Entretanto, vale retomar como, neste período considerado Antigüidade, era visto o professor.

Inicialmente, na clara divisão de classes sociais entre nobreza e escravos, o conhecimento valorizado referia-se à estratégias de guerra e artes militares, sendo outros assuntos considerados de menor importância.

Neste contexto, segundo Marrou (1975, p.229), "quanto ao próprio mestre, temos a surpresa de descobrir quão pouco caso a sociedade antiga fazia dessa função docente que a nossa considera, ou pretende considerar, com respeito e honra". Ainda para este autor, o oficio de professor segue durante toda a Antigüidade sendo um ofício humilde e bastante desprezado, chegando a ponto de ser referência sobre alguém de quem não se tivesse notícias por um tempo: "ou morreu, ou é instrutor em alguma parte".

Com exceção das grandes cidades como Mileto ou Teos, onde as escolas se tornaram públicas e os professores eram eleitos pela assembléia dos cidadãos, participando da dignidade similar à do magistrado público, ser professor tinha um sentido comercial e de subserviência, pois era o professor que saía em busca de conseguir alunos e ainda tinha que pedir pagamento pelos ensinamentos, atitude que para a época, era considerada desonrosa aos olhos da aristocracia. $O$ ofício de professor também não era considerado, pois não requeria qualificação especial, ou seja, não há em parte alguma, neste período, uma formação profissional específica. Ao eleger um professor, não era exigido do candidato nenhum título e os eleitores faziam as escolhas baseando-se nos que demonstravam maior capacidade em ocupar-se com crianças e apesar de não se exigir nenhuma garantia, saber ler era considerado tecnicamente suficiente para ensinar e do ponto de vista moral, eram considerados o caráter e a honorabilidade.

O mestre das primeiras letras era encarregado apenas de ensinar a ler, o que era considerado de menor importância. Dessa forma, o mestre provia a inteli- 
gência da criança, mas não o educava, demonstrando que nesta época, a essência da educação era a formação moral, do caráter e do modo de vida.

Conforme destaca Hubert (1967), a associação que fazemos da conduta moral no ensino primário e que nos parece natural nos dias de hoje, é herança da Idade Média, mais precisamente da escola monástica, que recuperou a importância e a dignidade do ofício docente.

Embora o ofício de professor tenha sido considerado menor no passado, é certo que, por seus discípulos, sempre houve sentimentos de admiração e respeito para com seu mestre, especialmente no ensino filosófico, que era organizado de três formas: uma na qual o ensino era oficializado no centro da escola, na forma de confrarias, fundadas por mestres cujos ensinamentos eram transmitidos de geração em geração, perpetuando-os. Outra forma eram os mestres que ensinavam por conta própria isolados em suas cidades, havendo ainda, a dos filósofos errantes que, ao ar livre, se dirigem aos ouvintes. Estes últimos, segundo Marrou (1975, p.230), 'terão eles contribuído para despertar vocações; mas, salvo exceções, não promoveram ensino regular e completo de filosofia".

Como vimos, anteriormente, o Império Romano dominava não só um continente terreno como toda a cultura nele existente, modificando, lentamente, o cenário da situação de como eram vistos os instrutores, que passaram a ser alvo de um olhar um pouco mais condescendente quanto à sua valorização, posto que foi solicitada a vinda de inúmeros professores competentes ${ }^{9}$ para ensinar em Roma (id.ibid).

As influências da cultura greco-romana nas suas instituições e também em outras instituições do mundo ocidental foram limitadas com a decadência do Império Romano e com as invasões "bárbaras", cedendo lugar à Igreja Cristã, com uma força espiritual sobrepondo-se à antiga cultura, preservando-a, entretanto com uma condição: submetendo-a ao seu crivo ideológico.

Gadotti (1999) afirma que a fé cristã e as doutrinas greco-romanas seguiram conciliadas ${ }^{10}$ do século I ao VII d.C. por inúmeras escolas catequéticas espa-

\footnotetext{
${ }^{9}$ Um episódio curioso neste período é a primeira perseguição escolar em que as vitimas são os cristãos. Por uma lei de 17 de junho de 362, o ensino era interditado aos cristãos pelo imperador Juliano. 0 texto da lei falava em submeter o exercício da profissão pedagógica à autorização prévia das municipalidades e à sanção imperial, no intuito de assegurar a competência e a moralidade do pessoal docente. Anexo a esta Lei, em uma circular, o imperador Juliano deixava explícito o que era para ser entendido como moralidade. Dessa forma, os cristãos explicavam Homero e Hesíodo, sem acreditar nos deuses que estes poetas punham em cena. Assim, ensinavam algo em que não acreditavam e eram obrigados a renunciar ou deixar o ensino. Cf.GADOTTI, 1999.

${ }^{10} \mathrm{O}$ termo indica compartilhamento, entretanto, a Igreja teve que admitir a cultura antiga conservando o caráter sacerdotal e por outro lado um acordo imposto pelas necessidades da vida e uma oposição entre a doutrina cristã e a cultura pagã. Durante este período acima citado, a cultura antiga foi praticamente extinta do mundo ocidental.
} 
Ihadas pelo império e nos séculos seguintes, surgiu a centralização do ensino por parte do Estado Cristão.

A igreja cristã, com o poder de Cristo e a máxima "Eu Sou o caminho, a verdade e a vida... todo o poder me foi dado", se sobrepôs às culturas anteriores, até então pautadas no heroísmo, no aristocratismo e na vida terrena.

Sob a perspectiva da pedagogia, Cristo pode ser considerado um grande educador e bastante popular, utilizando seus conhecimentos em caminhadas pela Palestina que, transformados em parábolas, constituíram a base de seus ensinamentos ligados à vida. Ele tinha como característica o domínio da linguagem erudita e a facilidade de comunicar-se com os mais humildes, sendo esta uma habilidade que contribuiu muito para o sucesso da igreja e de seus representantes.

Posteriormente, São Paulo buscou universalizar o cristianismo, unindo gregos e romanos e mais tarde, num período compreendido entre 150 a 430 d.C., Clemente de Alexandria, Orígenes, São Gregório, São Basílio, São João Crisóstomo, São Jerônimo e Santo Agostinho determinaram, para a nova religião, a necessidade e a prescrição de um corpo de doutrinas, dogmas, culto e disciplina. Com isto, criaram uma educação para o povo, a educação denominada catequética, e outra para o clérigo, que era humanista e filosófico-teológica, ou seja, foram estabelecidas duas formas de educação, com conteúdos e destinações distintas.

A educação medieval se organizou na idéia central de que a religião era tudo para o homem. Neste período os conteúdos ensinados partiam de determinados talentos intelectuais, dando um significado de ornamento estético ao cidadão, ou ainda de instrumentos úteis para a vida. Segundo Durkheim,

\footnotetext{
O Cristianismo, ao contrário, teve mui presto a percepção de que, sob a condição particular da inteligência e da sensibilidade, jaz em cada um de nós, um estado profundo que cumpre atingir, se se quiser fazer verdadeiramente obra de educador, exercer ação duradoura, produzir, enfim certa atitude da alma, certo habitus do ser moral. (apud Hubert; 1967, p.27)
}

Os estudos medievais eram baseados em determinadas obras e uma delas, o De originibus de Beda, 'o Venerável' (672-735) sob o pretexto de buscar a origem das palavras, tornou-se um resumo de toda a ciência pré-medieval, pois ia das palavras às coisas, passando por todas as disciplinas humanas, desde a gramática, medicina, jurisprudência, história natural, até a teologia. Estas disciplinas se dividiam entre o trivium (gramática, dialética, e retórica) e o quadrivium (aritmética, geometria, astronomia e música) e compreendiam os estudos medievais. Entretanto, as educações monástica e eclesiástica medieval foram deterio- 
rando, fazendo com que os períodos compreendidos entre os anos de 600 e 850 fossem considerados os mais obscuros da Idade Média.

No decorrer dos séculos VIII e IX, as atuações de dois grandes monarcas, Carlos Magno e Alfredo, 'o Grande', preocupados não só com a educação dos eclesiásticos, mas também com a educação do povo e da nobreza, foram importantes para a resignificação do ensino e da educação.

Após unificar quase toda a Europa, Carlos Magno constatou deficiências na cultura eclesiástica e secular. Buscando sua transformação, inicia em seu próprio palácio uma escola freqüentada por ele próprio, sua família e alguns nobres selecionados para o Serviço da Igreja e do Estado, seguindo a tradição Merovíngia $^{11}$ Carlos Magno colocou Alcuíno, considerado uma iminente figura e que fora educado no mosteiro de York, como mestre e responsável pelos ensinamentos, e os trabalhos ali desenvolvidos englobavam toda a sorte de assuntos, desde as mais elementares até as humanistas em latim e grego, ensinando também poesia, aritmética, astronomia e teologia. O monarca tomava parte ativa no ensino, por meio de discussões e diálogos.

Além das criações palatinas, no intuito de elevar a educação do povo, Carlos Magno baixou "Proclamações" e "Editos". Com o primeiro, expedido no ano de 787 e após constatar o estado de ignorância dos membros da igreja e dos Mosteiros, exortou-os não só a não descuidar do estudo das letras, mas também a estudar com humildade e seriedade para que pudessem ser capazes de penetrar fácil e corretamente nas escrituras sagradas, explicitando ainda que "para essa obra hão de ser escolhidos homens que tenham vontade e capacidade de aprender e desejo de ensinar aos outros” (LUZURIAGA, 1969, p.82), representando a recuperação parcial dos conceitos aristotélicos sobre os fatores determinantes para o desenvolvimento espiritual do homem: disposição inata, hábito e ensino, ou seja, as competências e habilidades dos estudiosos e professores.

Posteriormente, outras proclamações foram baixadas, instituindo escolas em todas as paróquias onde as crianças pudessem aprender a ler e escrever, sendo trazidos mestres de Roma e instituídos funcionários para servirem de inspetores de ensino.

Por sua vez, continua o autor, Alfredo 'o Grande' realizou na Inglaterra trabalho similar, trazendo sábios e educadores de fora, com intenção de elevar o

\footnotetext{
${ }^{11}$ Obra de A. Thierry; foi considerado um modelo de ensinamento da narrativa dos tempos de um período da história da França.
} 
nível cultural, preparando assim o terreno, para o futuro aparecimento das universidades.

Por volta do século $X$ e, sobretudo no século $X I$, o movimento intelectual do Islã atingiu seu apogeu. Estudiosos passam a comentar, traduzir e interpretar Aristóteles, dominando as ciências exatas e experimentais, completando as obras dos algebristas e aritméticos, dos astrônomos, dos médicos e aclarando o saber antigo. Essas idéias partem da Síria, do Egito, da Sicília, da Espanha e sobrepujam o pensamento do Ocidente, que se encontrava, então, preso às noções inconsistentes e confusas dos últimos enciclopedistas latinos. Este movimento se introduz em todas as escolas no século XII, tornando-o povoado de efervescentes idéias e de doutrinas.

Sob influência da cultura oriental arábica, surge nos meados do Século XII a primeira universidade européia, a Escola de Medicina de Salerno, na Itália, surgindo ainda neste mesmo século, a Universidade de Bolonha, dedicada especialmente ao estudo de Direito. No século XIII, voltada para a cultura ocidental, é implantada na França a Escola Catedral de Notre Dame, modelo para as demais universidades européias, que ao final do século $\mathrm{XV}$, já totalizavam cerca de oitenta unidades.

O nascimento bem como as formas de organização das universidades eram variadas, sendo que muitas surgiam da autoridade e atração de um determinado mestre, enquanto outras eram fundadas por Papas e outras ainda, por ordem do príncipe ou ainda eram criadas por ambos os poderes.

Quanto à organização, eram sociedades ou agrupamentos de mestres, ou corporações de estudantes ou ainda corporações constituídas de mestres e estudantes. Independentemente da forma como eram criadas ou organizadas, o certo é que após algum tempo, recebiam privilégios dos Papas e dos reis.

Estes privilégios eram variados, englobando imunidade e isenção de impostos; direito de greve ou mudanças de estudo quando ocorria algum descontentamento; de jurisdição interna para julgar seus membros e o direito de conceder graus ou licença para ensinar. Segundo Luzuriaga (1969, p.85),

as universidades surgem como 'studium generale' e depois como 'universitas studiorum', expressões nas quais a palavra universidade não significa a enciclopédia dos estudos, mas seu caráter geral, para todos os estudantes, fossem de que país fossem. (grifos do autor) 
Embora de um modo geral as universidades fossem autônomas com relação ao poder do governo e consideradas verdadeiras repúblicas, eram subordinadas ao Estado e à Igreja. Podiam eleger seus reitores, autoridades, nomeavam os professores e concediam três graus: Bacharel (baccalarius) era o primeiro grau e consistia numa espécie de aprendiz de professor; licenciatura (licentia) era o segundo grau, que capacitava o professor para ensinar, e o terceiro grau eram os de mestre ou doutor. Esta característica seria em muitos casos, tempos adiante, suprimida, graças à assumpção pelo Estado das funções de organização dos sistemas educacionais.

O conteúdo ensinado nas universidades baseava-se na lectio que era a exposição e análise de textos, nas quaestiones que eram a argumentação, e nas disputationes que eram as discussões de temas sugeridos pelo mestre, observando ainda o autor que as universidades,

[...] culturalmente representaram o ápice da sabedoria da época até a Renascença, época na qual começam a declinar por ater-se às tradições escolásticas e não admitir senão mui tardiamente as ciências novas (id.ibid.).

Neste mesmo sentido, Gadotti (1999, p.56) cita que "o que se constatou é que o saber universitário aos poucos foi se elitizando, guardado em Academias, submetido à censura da Igreja e burocratizado pelas Cortes".

Ainda no Século XIV, Henrique II de Castela (provavelmente em 1370) e posteriormente confirmada pelos Reis Carlos V, por Filipe II e Filipe III, o Poder Real interveio, ao publicar a primeira disposição regulamentadora sobre o exercício dos professores ou mestres, na qual eram concedidos diversos privilégios a eles, sendo proibindo a prática do ensino a quem não fosse examinado previamente, instituindo ainda fiscais para inspecionar o ensino, representando, portanto, os primórdios da regulação do Estado sobre a educação.

No final do século XIV e até o século XVI, tem início um período de renovação do pensamento humano chamado espírito da Renascença, que se manifestou, primeiramente, na Itália por circunstâncias diversas como: rejeição às disciplinas medievais; viagens a regiões distantes; descobrimento do novo mundo; relações com o Oriente; intensidade da vida municipal e emancipação filosófica dos espíritos. Todos estes acontecimentos foram influências que se associaram para suscitar o hábito da comparação, o senso do relativo, o desenvolvimento do espírito crítico e do espírito científico, favorecendo a autonomia do indivíduo. 
A Renascença não se constituiu em mais um movimento erudito ou literário, mas sim em uma forma de vida nova, alicerçada na personalidade humana livre e na realidade presente. Assim, a Renascença rompe com uma visão devota, contemplativa e triste, característica da Idade Média, cedendo lugar à uma concepção alegre e prazerosa da existência humana. (LUZURIAGA 1969, p.93)

Neste período, o pensamento pedagógico se caracterizou pela revalorização da cultura greco-romana que praticamente fora ignorada na Idade Média. Segundo Gadotti (1999, p.61), "essa nova mentalidade influenciou a educação, tornando-a mais prática, incluindo a cultura do corpo e procurando substituir processos mecânicos por métodos mais agradáveis".

Para Luzuriaga (1969, p.94), pedagogicamente, a Renascença exprime principalmente:

1. Redescobrimento da personalidade humana livre, independente de toda consideração religiosa ou política.

2. Criação da educação humanista, baseado no novo ponto de vista, no conhecimento de Grécia e Roma.

3. Formação do homem culto, ilustrado, fundada nas idéias de Platão e de Quintiliano, então descobertas.

4. Formação do cortesão instruído e urbano, em contraposição ao cavaleiro medieval, de pouca ilustração e caráter rural.

5. Cultivo da individualidade, da personalidade total e não só da religiosa e mística.

6. Desenvolvimento do espírito de liberdade e da crítica, ante a autoridade e a disciplina anteriores.

7. Estudo atraente e ameno, contra o imposto e dogmático da Idade Média.

8. Cultivo das matérias realistas e científicas, ainda que com predomínio das literárias e lingüísticas.

9. Consideração da vida física, corporal e estética, com especial cuidado da urbanidade e das boas maneiras.

10.Posto se trate essencialmente duma educação de minorias, o desenvolvimento das invenções técnicas, como a imprensa, facilita a difusão da cultura e da educação das massas.

11.Na organização escolar surge novo tipo de instituição educativa, o Colégio humanista ou escola secundária, baseado no estudo do latim e do grego.

A Renascença se expandiu no século XV da Itália por toda a Europa, sendo prontamente acolhida e rapidamente difundida especialmente na Alemanha e França, adquirindo um caráter intelectual e escolar maior nestes países do que na própria Itália. Dessa forma, afirma Gadotti (1969, p.62), caracterizada pelo individualismo liberal, pelo aristocratismo e elitismo, a educação renascentista não conseguiu atingir as massas populares, preparando a formação do homem burguês. 
Como parte do movimento humanista da Renascença, surgiu na Alemanha, no século XVI a reforma religiosa protestante (1520-1564) que se rebelou contra a Igreja, por esta ter-se desviado de suas antigas crenças ${ }^{12}$.

Lutero $^{13}$, doutor em Teologia e comentador da Bíblia, assim como outros, não tinha a pretensão de se separar da Igreja Católica. Entretanto, ao fazer um protesto em nome da fé cristã contra a "venda" de indulgências em 1517, foi combatido pelos legados do Papa. Posteriormente, Lutero publicou dois violentos manifestos contra os católicos, queimou o decreto que o condenava e ainda se recusou a uma retratação. Foi a coragem de sua atitude e a qualidade de sua fé que levaram a Alemanha e outros países a serem seus seguidores, contra a Igreja Católica Tradicional.

Este movimento da Reforma, que viria influenciar também a educação, desencadeou, no campo social, um outro movimento: a revolta dos camponeses contra os seus senhores. O homem experienciava neste período, o Humanismo e a Reforma, havendo, conforme aponta Luzuriaga (1969, p.108), pontos convergentes e divergentes entre estes movimentos.

Humanismo e Reforma, entretanto, convergiam ao buscar inspiração na vida espiritual, no interior do homem salientavam a personalidade autônoma, a individualidade livre, fosse ela intelectual, religiosa e, ainda, possuíam um sentido crítico quanto à total autoridade dogmática.

No entanto, divergiam no sentido que o Humanismo possuía uma marca intelectual e estética, envolvendo a aristocracia e, portanto, uma minoria da população, enquanto na Reforma prevalecia o aspecto ético e religioso e era considerado, sobretudo um movimento social e popular dando origem à educação pública que se organizava não apenas no grau médio, aumentando a atuação dos colégios humanistas, mas também e pela primeira vez, com a escola primária pública.

\footnotetext{
${ }^{12} \mathrm{O}$ cristianismo dá origem ao catolicismo, pregando o amor incondicional e a fé. Aos poucos a Igreja Católica se estabelece como organização, dominando o continente europeu, impondo regras em nome de Deus, distanciando-se assim de seus princípios primevos. Cf. Gadotti (1969).

${ }^{13}$ Martim Lutero nasceu em Eisleben, Alemanha, no dia 10 de novembro de 1483, ordenando-se monge católico em 1507. Estudioso da bíblia, traduziu-a para 0 alemão para que todos tivessem acesso às escrituras já que, até então, encontravam-se somente em latim, permitindo a todos um conhecimento que durante muito tempo foi guardado somente pela igreja. Analisando os pensamentos bíblicos importantes que estavam à margem da vida da igreja naquele momento, descobriu que para ganhar o perdão de Deus ninguém precisava castigar-se ou fazer boas obras, mas somente ter fé em Deus. Decidiu tornar públicos seus pensamentos por meio de 95 teses que foram fixadas na porta da igreja do castelo de Wittenberg, no dia 31 de outubro de 1517, acreditando que a Igreja precisava ser renovada a partir do Evangelho de Jesus Cristo. Foi excomungado em 1521 pelo Papa Leão X. No ano de 1525 casou-se com a monja Katharina von Bora, com quem teve seis filhos. O Movimento da Reforma espalhou-se pela Europa e em 1530 os líderes protestantes escreveram a "Confissão de Augsburg", resumindo os elementos doutrinários fundamentais do luteranismo. Em 18 de fevereiro de 1546, aos 62 anos, Martim Lutero faleceu. Finalmente, em 1555, o Imperador reconheceu a existência de duas diferentes confissões na Alemanha: a Católica e a Luterana.
} 
A Reforma proporcionou, à educação, o emprego dos idiomas vernáculos nacionais, em vez do latim, que era exclusivo no ensino anterior, sendo este fato, neste período, um marco decisivo para a educação.

No ensino médio, houve a criação dos Colégios Humanistas, que com a inspiração cristã e no sentido da Reforma, continuaram a ministrar o ensino das humanidades clássicas. Com a expansão da Reforma protestante na Europa, mostra Luzuriaga (1969), a Igreja foi obrigada a ceder espaço, mas foram empregadas duas maneiras de intervenção: a luta direta e a reforma interna da própria Igreja, dando origem ao movimento chamado Contra-Reforma e que duraria por volta de dois séculos.

A reforma religiosa tocou, diretamente, os aspectos políticos e econômicos, gerando um período intenso de guerra cruel em toda a Europa, adotando inicialmente o aspecto de luta político-religiosa entre os estados católicos e os estados protestantes, que ao seu final perdeu o cunho religioso, limitando-se ao político. Diante deste cenário e analisando os acontecimentos, os dirigentes católicos mais esclarecidos retornaram sobre o próprio sentido das doutrinas católicocristãs, agora com o objetivo de manter os valores morais e religiosos, livres, para conservar somente o poder moral e espiritual da fé e da organização religiosa da Igreja. Assim,

a contra-reforma assumiu o aspecto de luta pacífica, reivindicatória da pureza e da originalidade cristã das doutrinas católicas romanas. Para tal fim, foram utilizados muitos dos próprios meios protestantes, entre os quais a educação. (LAROUSSE, 1998, p.2197)

A pretensão da Contra-Reforma, segundo Luzuriaga (1969, p.117), era "volver, de certo modo, à situação anterior ao Humanismo, no sentido de suprimir o espírito crítico da razão e submeter a religião aos ditames da autoridade eclesiástica." Para tal missão, os dirigentes eclesiásticos da Igreja Católica Romana criaram inicialmente os tribunais da "Inquisição"14 e posteriormente, dois órgãos de ação: a Companhia de Jesus (1534), e o Concílio de Trento (1545-1563), que,

\footnotetext{
${ }^{14} \mathrm{~A}$ Inquisição foi criada e dirigida pela Igreja Católica Romana no século XIII, em plena Idade Média, sendo composta por tribunais que julgavam todos aqueles considerados como ameaça às suas doutrinas. Todos os suspeitos eram perseguidos e julgados, sendo os considerados culpados levados a penas severas, variando da prisão temporária ou perpétua até a morte em fogueiras em praça pública. Com o passar do tempo, esta forma de julgamento foi ganhando cada vez mais força e tomando conta de países europeus (Portugal França, Itália e Espanha) com exceção da Inglaterra, onde não houve o firmamento destes tribunais, tornando-se muito poderoso, o que atraiu interesses políticos diversos, possibilitando perseguições a nobres e judeus na Espanha do século $\mathrm{XV}$. Milhares de pessoas foram torturadas ou queimadas vivas por acusações que, muitas vezes, eram injustas e infundadas. Com poderes cada vez maior nas mãos, o Grande Inquisidor chegou a desafiar reis, nobres, burgueses e outras importantes personalidades da sociedade da época, perseguindo os "hereges" até o início do século XIX. No Brasil, embora os tribunais tenham sido instalados na época colonial, não apresentaram a mesma força política como na Europa, tendo sido julgados, principalmente no Nordeste, alguns casos de heresias e comportamento de brasileiros e judeus.
} 
embora distantes no tempo, coincidiam nos objetivos político-ideológicos de expansão e manutenção da sua área de influência.

O grande poder de dominação do Concílio de Trento constituiu-se na criação do Índex Librorum Prohibitorum, um índice de livros proibidos aos católicos, conforme interpretação do Papa. No tocante à Educação, foram mantidas as recomendações aos bispos e autoridades eclesiásticas voltadas à criação de escolas e à execução de melhorias nas já existentes em catedrais e mosteiros, além da fundação do ensino secundário com a introdução da disciplina de gramática e com a instrução de que fosse gratuita aos clérigos e estudantes mais pobres. ${ }^{15}$

Entretanto, afirma Luzuriaga (1969), o instrumento principal da ContraReforma foi a Companhia de Jesus, fundada em 1534 por Inácio de Loyola ${ }^{16}$ e reconhecida pelo Papa em 1540, que foi considerada, durante muito tempo a organização mais poderosa que a Igreja possuiu para a educação, com certa influência ainda hoje. Inicialmente criada com o propósito de pregação, confissão e catequização, a Companhia de Jesus exerceu significativa influência ideológica, psicológica e religiosa entre os adultos a partir dos chamados "exercícios espirituais" que consistiam a sua principal faculdade.

O objetivo primeiro era combater as heresias protestantes, substituindo os meios materiais da luta armada e inquisitorial, de triste história, pela pregação e pelo debate dos valores espirituais da Igreja. Paralelamente, o segundo objetivo consistia na conversão dos pagãos que habitavam os novos mundos descobertos por portugueses e espanhóis que, seguramente, se colonizados, reforçariam o poder espiritual do papado. Assim, a Educação, tão necessária para este fim posto que necessitasse da preparação de líderes, foi paulatinamente ocupando espaço, vindo a se tornar na maior e mais importante atividade da Companhia, que era composta de membros de uma Ordem religiosa com estatutos e autoridades próprias e segundo Luzuriaga (1969, p.119),

\footnotetext{
${ }^{15}$ O Concílio de Trento, convocado pelo papa Paulo III, foi iniciado em 1.545 e perdurou até 1.563 , observando-se que suas determinações fortaleceram o catolicismo e orientaram a Igreja Católica até meados do século XX, reafirmando e mantendo todos os principais dogmas do catolicismo: a salvação da alma se dá por meio da fé e das boas obras; o poder do papa; o celibato clerical, e os sete sacramentos (eucaristia, batismo, penitência, confirmação da ordem sacerdotal, matrimônio e extrema-unção). Também determinou a criação de seminários para a formação de sacerdotes e realçou a importância da missa para relembrar o sacrifício de Cristo, considerando criminoso o lucro proveniente da venda de indulgências. É interessante que o Index Librorum Prohibitorum foi extinto apenas em 1965, por determinação do papa João XXII.

${ }^{16}$ Filho de família numerosa da nobreza rural com o nome de Iñigo López de Oñaz y Loyola, nasceu em 1491 no castelo de Loyola, província basca de Guipúzcoa ao norte da Espanha e, sendo ferido em batalha aos 30 anos, converteu-se ao catolicismo em 1527. Durante a convalescença, latiniza seu nome para Inácio e funda a Ordem dos Jesuítas, cujos princípios de obediência total ao Papa e votos de pobreza persistem até a atualidade. Faleceu em Roma em Julho de 1556 e foi canonizado em 1622, pelo Papa Gregório XV.
} 
A Companhia tem caráter sumamente empreendedor e combativo. Sua mesma designação de Companhia já indica o caráter de milícia, assim como a organização, disciplina e espírito de obediência, tudo para a maior glória de Deus (Omnia ad Majorem Dei Gloriam, ou abreviadamente, A.M.D.G). Dependem os membros de um Geral e em cada nação, de um Provincial, embora submetidos à autoridade do Papa.

Para orientar a prática da educação jesuítica, foi escrito o Ratio atque Institutio Studiorum ${ }^{17}$ que, após vários anos de aplicação e consultas, foi aprovado em 1599, cujos princípios fundamentais influenciaram todos os sistemas de educação que vieram a seguir, permanecendo ainda hoje subjacente em grande parte das escolas convencionais em três dos passos básicos de uma aula: preleção do conteúdo pelo professor, levantamento de dúvidas dos alunos e exercícios para fixação, cabendo ao aluno a memorização para a prova. (ANASTASIOU, 2003, p.18)

Este regimento continha os planos, programas e métodos da educação católica e seu conteúdo abrangia a formação, em latim e grego, em filosofia e teologia. Seu método, que era predominantemente verbal, consistia em lição ou preleção, explicação, repetição, composição, memorização e competição ou emulação, ou seja, método ainda claramente utilizado no ensino reprodutivista tradicional. Esta última característica servia de base para a disciplina e fomentada individualmente, de forma que cada aluno possuía um adversário para competir, ou coletivamente, dividindo-se a classe em grupos igualmente adversários. A emulação também podia ocorrer entre escolas, por meio de exames, debates, etc., com o intuito de despertar o sentimento de competição e de amor-próprio, contudo, vinha acompanhada do sentido negativo, representado pela obediência e submissão mais completas, conservadas por uma constante vigilância que os próprios alunos faziam entre si, por meio de denúncias, comportamento este que cedia lugar a acusações e espionagens, consideradas impróprias na educação moral sadia (LUZURIAGA, 1969, p.119).

Para evitar qualquer forma de independência pessoal, tudo era previamente elaborado na educação jesuítica, incluindo a posição das mãos e o modo de levantar os olhos, conforme Gadotti (1999, p.65), contrariando frontalmente os ensinamentos a respeito da autonomia do educando, pois conforme Paulo Freire (1996, p.59), "o respeito à autonomia e à dignidade de cada um é um imperativo

\footnotetext{
${ }^{17}$ Cf. próximo capítulo.
} 
ético e não um favor que podemos ou não conceder uns aos outros." Para o autor,

O professor que desrespeita a curiosidade do educando, o seu gosto estético, a sua inquietude, a sua linguagem, mais precisamente, a sua sintaxe; o professor que ironiza o aluno, que o minimiza, que manda que "ele se ponha no seu lugar" ao mais tênue sinal de rebeldia legítima, tanto quanto o professor que se exime do cumprimento do seu dever de ensinar, de estar respeitosamente presente à experiência formadora do educando, transgride os princípios fundamentalmente éticos de nossa experiência. (p.60)

A educação dos jesuítas era voltada para a formação do homem cristão com base na doutrina da Igreja Católica e para tanto, empregava idéias e métodos humanistas, como os idiomas clássicos, mas de um modo geral não tinha o espírito dos humanistas, do sentido humano, da independência de pensamento, da função crítica, investigadora, livre de qualquer imposição e com isto, conservava o tradicional e o antigo.

Os aspectos restritivos que marcaram a educação jesuítica caracterizando uma limitação do ensino foram a aplicação de matérias exclusivamente clássicas e religiosas com marcas distanciadas da vida real presente, negligenciando as matérias de caráter realista e científico, e a história ensinada - que era a clássica e não a nacional, e o latim como a língua adotada e não o vernáculo. Outros aspectos igualmente restritivos eram as normas e regras impostas e a vigilância e denúncia de faltas que induziam os alunos ao caráter de desconfiança e individualismo. O que se constatava era a falta de independência intelectual, senso crítico e pessoal, posto que "tudo" já se encontrava pronto e descoberto, restando, aos alunos, receber passivamente os conteúdos. Em que pese alguns alunos serem brilhantes nas formas de expressão, na eloqüência e na redação, o conteúdo era sempre imposto e, conforme descrito por Freire (1987), funcionando o ensino nos moldes do "ensino bancário".

Entretanto, três aspectos podem ser considerados de grande relevância e contribuição para a educação advinda dos jesuítas, relativos à seleção dos professores, ao tratamento individualizado aos alunos e a educação integral.

O cuidado na seleção e preparação dos mestres, escolhidos pelas condições de caráter especiais e por serem pessoas que se acreditavam com maiores aptidões para o ensino, passando, posteriormente, por preparação intensa, possibilitou que os jesuítas tivessem mestres eminentes e em quantidade considerável, representando uma iniciativa interessante no sentido da qualificação dos docentes. 
Outro aspecto relevante, embora de conotação dúbia, era o tratamento individual dispensado aos alunos, pois estes eram estudados, conheciam-lhes o caráter e as condições intelectuais, sendo ainda destinado a cada aluno, um trato psicológico. O que era levado em consideração eram os dotes e aptidões pessoais e nem tanto o saber que possuíam, mas, por outro lado, suas fraquezas e deficiências puderam ser exploradas pelos mestres visando obter a completa submissão e dominação ideológica dos alunos, restringindo sua autonomia pessoal de todas as formas. Finalmente, a educação não enfatizava apenas o aspecto intelectual, mas era de certa forma, integral: física, estética e moral (LUZURIAGA, 1969, p.121). Sobre a educação jesuítica, destaca Hubert (1967, p.52),

[...] à ela é que se deve o que há de formalismo e de estreiteza, de maneirismo literário e de convencionalismo moral, de vã confiança, enfim, na superioridade desses pseudovalores, na formação da burguesia francesa até nossos dias. Porque a Universidade imperial mais não fez, a este respeito, que retomar-lhe e perpetuar-Ihe a obra, em proveito da mesma classe, com os mesmos fins, e pelos mesmos processos.

Outras ordens religiosas com o mesmo objetivo de pregação e educação tiveram início no século XVI, como as Ursulinas, a Congregação de Jesus, a Congregação da Doutrina Cristã, as Irmãs de Nossa Senhora e a Congregação das Escolas Pias, que, entretanto se desenvolveram durante o século XVII.

Segundo Luzuriaga (1969, p.125), o século XVII constitui "uma fase de transição entre o Humanismo e a Reforma, e a llustração e o Despotismo esclarecido do século XVIII" com características próprias relativas à educação e assim, os aspectos religiosos tanto da Reforma Protestante quanto da Contra-Reforma Católica tornaram-se cada vez mais evidentes, emergindo desses movimentos dois caminhos: um dogmático e fechado, e outro de cunho mais íntimo e piedoso.

Nos países protestantes houve o desenvolvimento da intervenção do Estado na educação, cuja legislação escolar era mais ampla e compreensiva e as novas idéias filosóficas da corrente idealista e da corrente empirista foram lentamente sendo aceitas. As idéias científicas, iniciadas no século anterior (Kepler, Galileu) começaram a ter repercussão e igualmente começaram a ser aceitas e esses movimentos filosóficos e científicos desencadearam o nascimento de uma nova didática. Sobre este cenário em que se desenvolve a educação no século XVII, Dilthey apud Luzuriaga (1969, p.125-126) diz que:

No século XVII, com base numa ciência chegada à maturidade, preparada pelo Humanismo e pela Reforma, surge das necessidades sociais um sistema científico que oferecia princípios universais para a conduta da 
vida e direção da sociedade. De acordo com o movimento progressivo, é o antagonista do velho sistema metafísico-teológico, que então tratava de renovar-se nos países latinos, Espanha e Itália.

Nos países protestantes já havia sido iniciado no século XVI um movimento de intervenção das autoridades públicas na educação que se desenvolveu no século XVII com maior participação do Estado, enquanto nos países católicos a educação continuou sob o domínio das ordens religiosas, especialmente dos jesuítas. As novas ordens e instituições religiosas do século XVII, também de caráter educacional, divergiam das ordens anteriores, particularmente da dos jesuítas (id.ibid).

No decorrer deste século, o acesso à escola foi motivo de luta entre as camadas populares, pois a formação da classe trabalhadora era estimulada por intelectuais iluministas e pelas novas ordens religiosas segundo a premissa de que poderiam e deveriam ter um papel na mudança social. Assim, a formação pela educação, foi essencial para articular interesses e construir sua própria cultura de resistência ao modo de vida anterior. Segundo Gadotti (1999, p.76),

Os séculos XVI e XVII assistiram a ascensão de uma nova e poderosa classe que se opunha ao modo de produção feudal. Esse estrato da sociedade impulsionou, modificou e concentrou novos meios de produção. Iniciou o sistema de cooperação, precursor do trabalho em série do século XX. Dessa forma a produção deixou de se apresentar em atos isolados para se constituir num esforço coletivo.

Nesta época, dois modelos de educação com diferentes características foram exportados para as colônias: um, eminentemente real e público, foi implantado na América britânica, com base no modelo de escolas dominicais e protestantes, e o outro, de cunho religioso e privado, para a América espanhola e portuguesa, que eram as escolas católicas (id.ibid).

O Instituto dos Irmãos das Escolas Cristãs, fundado por Jean Baptiste de La Salle em 1684 na França, foi o primeiro que se propagou amplamente devido à eficácia do ensino e à preparação dos mestres. Quanto ao ensino, o objetivo específico era dar instrução elementar e religiosa às crianças das classes trabalhadoras, na língua vernácula. Posteriormente, buscou fazer, na escola primária, o que os jesuítas fizeram na escola secundária, organizando um currículo graduado em classes, com métodos adequados de disciplina, caracterizado por uma regulação gradativa de punições.

É importante destacar que quanto aos mestres, conforme Larousse (1998), frente à dificuldade de conseguir professores capacitados que conduzis- 
sem o plano de trabalho nas escolas, fundou-se em 1685 em Reims, na Europa, a primeira Escola Normal, com o título de Seminário de Professores, voltada para a formação de professores de crianças.

Outras instituições católicas foram as escolas de Port-Royal (datadas de 1637), e as dos Oratorianos (estes de 1611) cuja influência intelectual foi menos extensa, porém mais profunda que a dos jesuítas.

A educação de Port-Royal (dos jansenistas ${ }^{18}$ ), era dada em pequenas escolas, com um número limitado de alunos escolhidos, e segundo Hubert (1967, p.53) "com largueza de vista e nobreza moral incomparáveis", para que os professores pudessem lhes dar o atendimento devido. Tinha como característica uma educação devota, contemplativa e, sobretudo, mediada pelo afeto e simpatia. Em oposição aos jesuítas, este novo modelo de educação estabelecia faculdades sólidas, tais como o juízo e a razão, além da introdução da compreensão e do amor, em substituição da idéia da emulação pregada pelos jesuítas, suprimindo-a do ensino. Embora não aplicassem um ensino científico nem histórico, "os professores já são pelo menos, embebidos do espírito da filosofia cartesiana, e todos os seus métodos procedem da noção, mui cartesiana, da eminente dignidade do pensamento lógico"(id.ibid).

Já a congregação do Oratório, fundada em 1611, destacou-se pela busca do saber, pelo liberalismo intelectual e pela solidez de seu caráter moral, ensinando as letras clássicas, a história, a geografia, as ciências e a filosofia de Descartes, sendo o castigo e a recompensa ainda adotados para se obter a disciplina, porém com menor rigidez que os jesuítas. Diferentemente dos jesuítas, a Ordem do Oratório era eminentemente nacional (francesa) e a maior importância de sua existência foi a de substituir as escolas dos jesuítas quando estes foram expulsos da França em 1762, cuja influência permaneceu até a Revolução (LUZURIAGA, 1969, p.130).

A renovação esperada, após a expulsão dos jesuítas, pela história moderna e o advento das ciências positivistas, não ocorreram e ao contrário, ocupou um espaço modesto e sempre ameaçado. Houve dificuldade em substituir os pro-

\footnotetext{
${ }^{18} \mathrm{~A}$ doutrina chamada jansenismo originou-se da obra do teólogo e bispo holandês Cornélio Jansenius intitulada Augustinus em que ele expunha, sob o seu ponto de vista, as doutrinas de Santo Agostinho sobre a graça, o livre arbítrio e a predestinação; a vontade do homem depois da queda, nunca foi verdadeiramente livre interiormente, porque ele está submetido quer à ambição e à sensualidade, quer à graça, e que a graça da salvação não é concedida senão aos eleitos, porque Jesus Cristo só morreu por estes. Tal doutrina é contrária à professada pela Igreja Católica.
} 
fessores e ainda faltou competência aos órgãos a que foram confiadas às administrações dos colégios.

Entretanto, à expulsão dos jesuítas seguiu-se a publicação de inúmeros trabalhos na França, dedicados a educação, com propostas semelhantes de torná-la uma obra do Estado apropriada à índole do país. Dessa forma, implantou-se a idéia de que o ensino era eminentemente objeto nacional e função do Estado. Este mesmo pensamento espalhou-se por Portugal, Alemanha e Espanha, onde, independentemente do ensino ministrado pelas ordens religiosas, sempre existiu a participação das autoridades oficiais, dando lugar a um início de intervenção do Estado no ensino (HUBERT, 1967, p.58).

$\mathrm{Na}$ Espanha do século XVII, o fato mais importante foi a criação da Irmandade de São Cassiano, que constituiu a organização de uma sociedade de mestres em forma de grêmio para defesa dos associados. Conforme Luzuriaga (1969), os regulamentos aprovados em 1666 determinavam que os mestres fossem examinados e que os pretendentes haveriam de permanecer praticando o ofício durante dois anos com mestres aprovados. Na mesma época, surgem na Alemanha as obras e idéias de novos pensadores e estudiosos, que viriam a revolucionar a educação neste e nos séculos seguintes, entre os quais se destacam Comenius considerado o fundador da didática, e Locke, o grande educador.

Comenius ${ }^{19}$ teve sua maior contribuição no tocante ao método, e mesmo influenciado pela tradição humanista realista, conseguiu aperfeiçoá-la e estruturála de maneira insuperável, principalmente ao adotar postulados democráticos com relação à educação das massas.

Locke $^{20}$, por sua vez, com sua obra intitulada "Pensamentos sobre a educação", editada em 1692, aliada à anterior denominada "Ensaio sobre e entendimento humano", esta de 1690, foi não apenas um pedagogo teórico, mas acima de tudo, um educador, constituindo-se em um grande marco na educação. Atuou como preceptor e conselheiro de muitos amigos e mesmo sendo considerado eli-

\footnotetext{
${ }^{19}$ Jan Amos Comenius (1592-1679), cujo nome original era Komensky, nasceu em Nivnitz (Morávia), tendo autor de inúmeras obras, entre as quais se destaca a intitulada "Didactica Magna". Bispo profundamente ligado aos ideais democráticos da educação, por ser representante de uma seita considerada comunista em termos da igualdade cristã, com atitudes liberais em favor da emancipação das massas e da educação para todos, encontrou pouca simpatia entre a maior parte da aristocracia e dos governantes da época. Cf. Eby (1976).

${ }^{20}$ John Locke (1632-1704), médico inglês, embora sendo profundamente aristocrático em seus pontos de vista educacionais, contrapondo-se em grande parte aos ideais propostos por Comenius, destacou-se mais pela concepção psicológica e moral, influenciando 0 ensino e considerado por muitos como o pai do liberalismo moderno e das idéias que serviram de base à constituição política da França e dos Estados Unidos da América. Dizia que "a monarquia absoluta é, na realidade, incompatível com a sociedade civil e nenhuma forma de governo pode ser assim, e em um estado natural, todos os homens são livres, independentes e iguais", pregando ainda a separação da Igreja e do Estado, e a liberdade de consciência para todos os que crêem em Deus. Cf.Eby (1976).
} 
tista em muitas colocações, representou profunda modificação na educação, principalmente no tocante aos objetivos desta e ao estabelecer que a utilidade determinava o currículo, no sentido mais amplo e filosófico. No entanto, a teoria de educação para Locke, era caracteristicamente britânica, assemelhando-se a um humanismo esmaecido e prático para a aristocracia, e de formação profissional para as massas. (EBY, 1976, p.263)

O Pietismo alemão representou nesta época um movimento igualmente de suma importância, na medida em que se contrapôs às guerras, pregando o auto-exame, amor e sacrifício, entre outras virtudes, fortemente imbuído de características pacifistas e integradoras das sociedades, assumindo postura crítica com relação às escolas religiosas da época. Entre os principais representantes deste movimento, destaca-se Francke ${ }^{21}$, cujas obras e atividades na esfera da educação influenciaram os demais estudiosos da época, em especial, com relação à sua determinação de que os professores deveriam ser formados, previamente, em seminários específicos, antes de ingressarem nas escolas. Seus projetos e suas obras foram utilizados em inúmeros países, entre os quais a América do Norte. No entanto,

[...] conquanto Francke tivesse muito em comum com Comenius, é preciso notar que Ihe faltava a amplidão de interesse social e científico do grande morávio. Ambos educariam todas as crianças. Comenius as formaria juntas nas mesmas escolas, sem distinções de classes; mas Francke estabeleceu escolas especiais para as várias classes da sociedade. Comenius ensinaria tudo a todos. Francke ensinou religião a todos, mas diferenciou o currículo para preparar as várias camadas sociais (EBY, 1976, p.245).

A análise do desenvolvimento da educação nos períodos subseqüentes demonstra que a segunda metade do Século XVIII foi o período-chave para a história da educação e da profissão docente, pois essa foi a época em que em toda a Europa buscou-se delinear o perfil do professor ideal, de tal forma que em nenhum outro momento da história, ocorreram tantas modificações e profundos avanços na esfera educacional como neste século.

A grande preocupação dos reis, pensadores e políticos no decorrer do século XVIII, aponta Luzuriaga (1969), se voltava para a educação, o que leva este século a ser considerado o século pedagógico por excelência, durante o qual

\footnotetext{
${ }^{21}$ August Hermann Francke (1663-1727) nasceu em Lübeck, estudioso de largo espectro, foi professor na Universidade de Halle, como outros pietistas da época, não era obscurantista nem conservador comum, criou inúmeras escolas e orfanatos em várias cidades e em vários países, influenciando a educação cristã, estabelecendo estudos realistas e atividades extracurriculares. Cf. Eby (1976).
} 
se desenvolveram a educação pública estatal, iniciando-se, ainda, a educação nacional.

Tempo de grande ebulição e modificações políticas e sociais, foi seguido de fases de decadência em termos de ensino, pois em função das variações políticas, os professores tiveram sua liberdade tolhida em vários países. No mesmo período, surgem novos autores e pensadores nos países centrais da Europa, que passaram a ter grande influência sobre as sociedades, incluindo os chamados "reformadores educacionais" ingleses, que seguiam políticas semelhantes compostas pela alfabetização universal, ensino de disciplinas de forte conteúdo prático, aliadas à pesquisa científica, engenharia e preparo industrial. Entre outros, podem ser destacados Hartlib, como um dos principais reformadores, bem como seus colaboradores e seguidores, Dury e Milton ${ }^{22}$.

A partir de inúmeras indagações sobre como deveria ser o professor ideal e de que forma este se engajaria em uma estrutura formal de organização, teve início um movimento de secularização e estatização do Ensino. Os processos de produção, a partir da maneira como os homens concebiam o mundo, constituíram os processos educativos, só que agora, rigorosamente, controlados pelos novos Estados "docentes", ou seja, controladores da educação. Novamente, nos moldes do Império Romano, o Estado intervém diretamente e passa a controlar efetivamente o sistema educacional e mediante esta estratégia, as formas e os modelos escolares elaborados sob a tutela da Igreja foram estendidos, agora, com um corpo de professores selecionados pelas autoridades estatais que passaram a lhe dar vida, resultando na efetiva estatização do ensino, de tal forma que Nóvoa (1995, p.15) afirma que

O processo de estatização do ensino consistiu, sobretudo, na substituição de um corpo de professores religiosos (ou sob o controlo da Igreja) por um corpo de professores laicos (ou sob controlo do Estado), sem que, no entanto, tenha havido mudanças significativas nas motivações, nas normas e nos valores originais da profissão docente: o modelo do professor continua muito próximo do modelo do padre.

\footnotetext{
${ }^{22}$ Samuel Hartlib (1600-1670), escritor e comerciante muito ativo, foi o responsável por despertar o interesse do povo inglês com relação a Comenius, induzindo o parlamento inglês em convidá-lo para expor seus planos educacionais, visando a reforma do ensino inglês, foi responsável pela publicação da principal obra de John Dury (1596-1680), chamada "Escolas Reformadas", e incentivador de John Milton (1608-1674), grande poeta inglês, com quem escreveu o tratado intitulado "Da Educação", marco para as posteriores mudanças na educação em todos os países. Dury, por sua vez, era um clérigo puritano que combinava o ideal puritano de Bacon com os ideais pedagógicos de Comenius, acreditando que o ensino deveria ser adaptado à capacidade mental das crianças. Já Milton, humanista estrito no sentido lato, era um grande erudito, e defendeu a fundação de um sistema de academias que deveriam suplantar as escolas latinas então existentes, além de defender a tolerância religiosa, contribuindo enormemente para a reformulação do ensino, ao propor estrutura curricular ampla incluindo vários campos práticos e experimentais. Cf. Eby (1976).
} 
Frederico Guilherme I (1688-1740) inicia a implantação da obrigatoriedade escolar em um grande estado, no caso a Prússia (atualmente Alemanha), seguido de seu sucessor Frederico Guilherme II, 'o grande'(1712-1786), fazendo com que a separação da educação entre o Estado e a lgreja, fosse secularizada e estabelecida de forma sistemática, inclusive estabelecendo os princípios do funcionamento do ensino privado. Entre as principais modificações do ensino alemão destacam-se a obrigatoriedade escolar para todas as crianças entre cinco e treze (ou catorze) anos e principalmente, se torna obrigatória a preparação dos professores, vedando o ensino com pessoas leigas ou sem títulos correspondentes ao nível escolar, além de estabelecer em 1794, que

\begin{abstract}
as escolas e universidades são instituições do Estado, que tem por fim a instrução da juventude nos conhecimentos úteis e científicos. Todas as instituições escolares, públicas e privadas, estão submetidas à inspeção do Estado e se acham sujeitas, em qualquer tempo, aos exames e visitas de sua inspeção.. A ninguém pode ser negada a admissão à escola pública pela diferença da confissão religiosa. As crianças que devam ser educadas, pelas leis do Estado, em outra religião que não a ensinada em escola pública, não podem ser obrigadas ao ensino religioso dessa escola (LUZURIAGA, 1969, p.153).
\end{abstract}

Nos demais países-nações, especialmente na França, o ensino estatal inicia-se também no século XVIII, após o ocaso das escolas jesuíticas e na seqüência das grandes modificações políticas ocorridas nesta época, destacando-se a Revolução Francesa, a partir da qual a educação estatal, considerada então como sendo "do súdito", se transforma em educação nacional, voltada agora "para o cidadão". Enquanto aquela era a educação da obediência, intelectual e instrumental, dada com caráter de imposição, esta é a educação da liberdade, de caráter cívico e patriótico, exigida como direito do homem, nos moldes contemporâneos de uma educação efetivamente emancipatória.

Na Espanha e na América Espanhola, também no decorrer do século XVIII, o declínio da Companhia de Jesus fez com que o ensino fosse modificado, com os professores passando a ser nomeados a partir de concursos, criando-se novas instituições escolares, especialmente de caráter técnico e realista.

Todos estes acontecimentos marcaram profundamente as gerações seguintes de profissionais da área pedagógica, na medida em que ocorreu por um lado, a autonomia e independência dos docentes com relação aos párocos, já que então se encontravam sob a tutela dos Estados, que assumiam a responsabilidade sobre os sistemas educacionais. Por outro lado, conforme Nóvoa (1995), esta intervenção do Estado, na educação, provocou a homogeneização, além da unifi- 
cação e hierarquização em escala nacional de todos os grupos, representando o enquadramento estatal que instituiu os professores como corpo de profissionais e não como uma concepção corporativa do ofício. É importante destacar que os Estados passam a fornecer licença para lecionar, verdadeiro suporte legal e delimitador do campo profissional, criando exclusividade da ação, nesta área.

A criação desta licença (ou autorização) é um momento decisivo para o processo de profissionalização da atividade docente, uma vez que facilita a definição de um perfil de competências técnicas, que servirá ao recrutamento dos professores e ao delinear de uma carreira docente (NÓVOA, 1995, p.17).

Na América do Norte, inicialmente colônia inglesa e já independente, a educação inicialmente sofreu forte influência das idéias propostas por Francke ${ }^{23}$, principalmente nas regiões da Pensilvânia e Geórgia, fruto do movimento de expansão do ensino estabelecido por $\mathrm{Hecker}^{24}$ com base no pietismo alemão, especialmente com relação à formação específica dos professores, chegando até a exigir que os professores somente pudessem ser contratados após terem estudado em seu seminário.

Com o decorrer dos anos, no entanto, a educação na América do Norte perde o caráter eminentemente religioso, voltando-se mais para o ensino civil, fruto da implantação de modificações similares às ocorridas no Velho Continente, absorvendo os ideais revolucionários estabelecidos pela llustração Francesa, em contraponto ao conservadorismo britânico, tanto no governo quanto na esfera social e no pensamento.

É nesta época que Franklin ${ }^{25}$, influenciado por Locke, Dafoe e outros cientistas e economistas europeus e considerado um dos mais importantes reformadores da educação norte-americana, publica um panfleto intitulado "Projetos relativos à educação dos jovens em Pensilvânia" (1749), propondo a implantação de

\footnotetext{
${ }^{23}$ August Hermann Francke (1663-1727), educador prático cristão alemão, é considerado o chefe educacional do movimento pietista, movimento este surgido após a guerra dos trinta anos que devastou a região norte da Europa, cuja vertente doutrinária era representada por Philip Jacob Spener (1635-1705), acreditava que toda a degeneração e infelicidade humana residiam na negligência da genuína educação cristã na infância. Francke e seus seguidores eram incentivadores da formação específica do professor como condição necessária para que ele exercesse suas atividades, obrigando que eles fossem formados em suas escolas. Foi também um dos introdutores das atividades extra-curriculares nas escolas realistas, fornecendo equipamentos para cursos de mecânica, vidraria, gravação em cobre, entalhamento em madeira, entre outros, possibilitando a integração do ensino teórico com a prática. Suas idéias influenciaram a Prússia, Dinamarca e demais estados nações da época Cf.Eby (1976).

${ }^{24}$ Johann Julius Hecker (1707-1768) pastor e educador alemão, foi um dos responsáveis pela expansão das idéias pietistas propostas por Francke, com o qual estudara na Universidade de Halle, tendo papel decisivo na reforma da educação das crianças pobres em grandes cidades, com um ensino prático voltado para classes diferenciadas. Foi um dos precursores das idéias de Pestalozzi e Basedow, tendo seguido em muitos pontos, as propostas de Comenius e Semler. Cf.Eby (1976).

${ }^{25}$ Benjamim Franklin (1706-1790), cientista, autor, estadista e editor, foi um autodidata e ganhou reconhecimento internacional por suas obras, desempenhando papel fundamental no estabelecimento da República americana, era contrário ao sectarismo e contra o domínio eclesiástico nos negócios públicos. Em suas obras, demonstrava ser claramente a favor de uma educação voltada para a prática, e compartilhava das orientações realistas, influenciado pela escola pietista de Francke. Cf. Luzuriaga (1969).
} 
uma Academia na Filadélfia, voltada para o ensino de coisas práticas com cunho profissionalizante. Entre os principais aspectos das academias estavam a preocupação com o ensino da língua, literatura e oratória inglesas, a introdução de cursos científicos e o controle não sectário da instituição, que passa a ser dirigida por um conselho de curadores que se perpetuava. Este novo modelo de ensino foi expandido por toda a América do Norte, sendo considerada de caráter quase público, na medida em que eram seus dirigentes eleitos pela comunidade e pela igreja local.

Na mesma época, Rousseau ${ }^{26}$, considerado um dos precursores da escola ativa moderna por estabelecer que o princípio essencial da pedagogia seja 0 ensino com base na própria experiência, teve importância decisiva nas gerações seguintes de educadores e pensadores, entre os quais se destacam Kant, Basedow, Pestalozzi, Froebel, Schiller e Goethe, cujas obras apresentaram repercussões na educação e na pedagogia moderna, possibilitando as extraordinárias mudanças posteriores no ensino e na educação (HUBERT, 1967, p.258; EBY, 1976, p.327-341).

Basedow (1723-1790), teólogo e educador suíço, foi o criador do instituto pedagógico Philanthropiunum de Dessau, em 1774, voltado para a "formação de europeus como cidadãos do mundo e preparados para uma existência tão útil e feliz quão possível" (HUBERT,1967, p.258).

Johann Heinrich Pestalozzi (1746-1827), importante educador suíço nascido em Zurich, exerceu grande influência no pensamento educacional e foi um grande adepto da educação pública. Representou importante contribuição para a valorização do ideal do educador e contribuiu para a psicologização da educação, buscando fundamentá-la em postulados mais próximos da psicologia, de forma mais sistemática que Rousseau pretendia, pois considerava o renovar da educação como a verdadeira solução das questões sociais. Estas, segundo sua visão, "se situam não mais em plano filosófico e abstrato, mas no plano concreto e prático, no qual a própria existência o levara a encontrá-la." Acreditava acima de tudo, na inocência e bondade da natureza humana, pregando uma educação que associasse o trabalho manual à aquisição dos conhecimentos elementares, pois pos-

\footnotetext{
${ }^{26}$ Jean-Jaques Rousseau, nascido em 1712 em Genebra e falecido em Paris em 1778, não foi propriamente um educador, mas suas idéias influenciaram decisivamente a educação moderna, tendo sido um dos primeiros a considerar e expor claramente as diferenças entre as mentes das crianças e as dos adultos, em contradição às posturas anteriores, que consideravam a criança como um adulto pequeno. Outro ponto defendido por ele era que a educação deve preparar o homem para um destino instável e em um ambiente instável, pois a própria sociedade está sempre mudando e que a natureza humana está em processo de desenvolvimento (id.ibid).
} 
sibilitaria a retirada das pessoas da ignorância e da miséria. Segundo ele, "a escola é uma verdadeira sociedade, na qual o senso das responsabilidades e as normas de cooperação bastam para educar a criança, sem que seja preciso, para evitar os constrangimentos nocivos ou tudo quanto a emulação comporte de perigoso, isolar o aluno no individualismo. Mais ainda, o fator social intervém no plano da educação intelectual tanto quanto no domínio da moral. Para ele, o professor era comparado ao jardineiro que providenciava as condições para a planta crescer, pregando ainda que a educação sensorial é fundamental e os sentidos devem estar em contato direto com os objetos, pois a mente é ativa. Com Bell e Lancaster, Pestalozzi havia organizado uma espécie de ensino mútuo tal que os alunos se ajudavam uns aos outros em suas investigações. (HUBERT,1967, p.263; EBY,1976, p.384)

Froebel (1782-1852), alemão de nascimento, recebeu influência de Fichet, Schelling e Hegel, sendo considerado o seguidor maior de Pestalozzi e tinha como maior preocupação não apenas fazer com que seus alunos adquirissem conhecimentos positivos, mas suscitar-Ihes e encorajar-Ihes a atividade educacional, buscando, com sua iniciativa pessoal (motivacional), possibilitar o afloramento de suas competências e habilidades (HUBERT,1967, p.265; EBY,1976, p.444).

O século XIX foi marcado pela luta em se estabelecer a educação como um assunto do Estado, durante o qual não se reconheceu ainda o monopólio do Estado nessa instrução. Observa-se que a educação assume em cada país, as características e o caráter nacionalista, acentuando-se as diferenças nacionais. No entanto, constata-se que a educação pública fica amplamente garantida, sendo, na grande maioria dos países, exigido o título de professor para o exercício do ensino primário. Este período é caracterizado pela difusão de novas posturas e do estabelecimento de organizações educacionais mais modernas, tendo como ponto de partida a revisão efetuada por todos os países civilizados em seus programas e estruturas educacionais, de acordo com as propostas dos pensadores citados.

No final do século XVIII e início do XIX, houve grande desenvolvimento do sistema de ensino na América do Norte, destacando-se as realizadas após o término da Guerra Civil, com as modificações elaboradas, com clara influência das obras de Locke e de outros pensadores franceses, encabeçadas por Thomas Je- 
ferson $^{27}$, que propôs o estabelecimento de um sistema fundamentado na descentralização da educação com relação ao Estado Central e mesmo à Igreja, o que possibilitou a implantação de inúmeras escolas e universidades que, mesmo regidas sob leis estaduais, eram mantidas sob controle dos governos estaduais e locais e instituições particulares, sem a presença do governo federal.

De maneira similar, na Europa e demais países conhecidos, com a liderança exercida pela Alemanha, Grã-Bretanha França e Estados Unidos da América, a educação passa por grandes modificações estruturais, assumindo nítidos contornos nacionalistas. O ensino de línguas antigas, como grego e latim, é abandonado, com o inglês se transformando na língua internacional em substituição ao francês, e os currículos, em geral, são enriquecidos com conteúdos e estudos de caráter ativo, visando uma cultura mais ampla e informativa.

O modelo educacional mais adotado nesta época era o Prussiano, com forte influência dos pensadores alemães. Nestes anos dos primórdios da Revolução Industrial durante os quais as economias, até então agrárias, são profundamente transformadas pelos incrementos dos desenvolvimentos das maquinarias, as cidades vão gradativamente se tornando congestionadas pelo excesso de população e passam a apresentar novas conformações e infra-estruturas, voltadas para o atendimento das novas demandas sociais. Na segunda metade do século XIX, a situação social dos professores é percebida de forma ambígua, na medida em que são vistos de várias formas distintas:

não são burgueses, mas também não são povo; não devem ser intelectuais, mas também tem de possuir um bom acervo de conhecimentos; não são notáveis locais, mas têm uma influência importante nas comunidades; devem manter relações sociais com todos os grupos sociais, mas sem privilegiar nenhum deles; não podem ter uma vida miserável, mas devem evitar toda a ostentação; não exercem seu trabalho com independência, mas é útil que usufruam de alguma autonomia; etc. (NÓVOA, 1995, p.18).

No final do século XIX, eclode na Europa e na América, grande insatisfação com relação aos sistemas educacionais, devido à grande expansão dos conhecimentos, bem como à intensificação do conceito de nacionalismo e dos conflitos entre as várias correntes filosóficas, além do grande impacto causado pela teoria da evolução biológica, estabelecida por Charles Darwin. Esta teoria, refor-

\footnotetext{
${ }^{27}$ Thomas Jefferson (1743-1826) foi o $3^{0}$ Presidente dos estados Unidos da América (1801-1809), nascido perto de Charlottesvile, na Virgínia, se tornou advogado e político influente, considerado como uma das pessoas mais cultas de sua época e um dos maiores responsáveis pelo caráter democrático do modo de vida norte-americano. Foi fundador da Universidade da Virgínia, na qual todas as ciências deveriam ser ensinadas e no mais alto nível possível. Tendo dedicado sua vida ao serviço público, sempre sustentou que a educação popular é problema do Estado e vital para seu bem-estar. Cf. Eby (1976).
} 
çada pela de Herbert Spencer (1820-1903), que, mesmo sendo elaborada com base filosófica, provocou certa revolução do pensamento, além das palestras e do esforço pessoal do cientista Thomas H. Huxley (1825-1895).

Tido como um dos responsáveis pela introdução do estudo das ciências nas escolas, Huxley possibilitou a popularização do conhecimento científico, por intermédio de conferências proferidas a trabalhadores e sermões leigos populares, defendendo a idéia da necessidade de serem implantadas escolas em todos os níveis, o que representaria, nas suas palavras "uma escada da sarjeta até a Universidade" (EBY, 1976, p.510).

A partir deste, novas modificações se verificam no ensino, destacando-se Hall $^{28}$, pensador norte-americano, responsável pela introdução da Psicologia Genética, com grande influência na Educação, foi um dos maiores divulgadores da teoria da evolução de Darwin. Escreveu cerca de 400 obras, envolvendo os mais variados tópicos, desde o regime das creches, reconstrução do jardim da infância, reforma da escola dominical e principalmente, a reorganização das escolas normais para a formação de professores.

As escolas normais representam uma conquista importante do professorado, que não mais deixará de se bater pela dignificação e prestígio destes estabelecimentos: maiores exigências de entrada, prolongamento do currículo e melhoria do nível acadêmico são algumas das reivindicações inscritas nas lutas associativas dos séculos XIX e XX. As escolas normais estão na origem de uma verdadeira mutação sociológica do corpo docente: o "velho" mestre-escola é definitivamente substituído pelo "novo" professor de instrução primária (NÓVOA, 1995, p.18).

Já na transição do século XIX para o século XX, merecem especial destaque as inúmeras obras de Dewey ${ }^{29}$, que teve importância fundamental para a educação moderna em todos os países, tendo feito conferências no Japão, China, Rússia, Turquia, México, entre outros. Ao contrário do pensamento vigente em sua época, Dewey considerava que a educação era um processo e a escola uma

\footnotetext{
${ }^{28}$ Granvilel Stanley Hall (1844-1924), nascido em Massachusetts, estudou filosofia e teologia na Alemanha, sendo professor na Universidade de Harvard, onde recebeu o grau de Ph.D em 1878. Retornando para a Alemanha, especializou-se em várias áreas, entre as quais Psicologia, Teologia, Filosofia, Antropologia, Biologia, Fisiologia, Anatomia e Neurologia, o que demonstra sua formação inigualável e de alta complexidade. Foi o responsável pela criação da Psicologia Genética, realizando inúmeros estudos sobre a saúde e desenvolvimento físico e mental das crianças e adolescentes. No terreno do ensino, Hall discutiu que os métodos devem ser adaptados à matéria, e também, à psicologia de cada fase específica do ensino, devendo ser a educação do adolescente bem diferente daquela das crianças pré-adolescentes, por exemplo. Cf. Eby (1976).

${ }^{29}$ John Dewey (1859-1952), nasceu em Burlington, Vermont, estudou filosofia, recebendo na Universidade Jonhs Hopkins o grau de $\mathrm{PhD}$. em 1880. Especializou-se em História Política e das Instituições e foi professor nas Universidades de Michigan, Chicago e Colúmbia, onde foi Professor Emérito. Autor de inúmeras obras, entre as quais "A escola e a sociedade", e "Como pensamos", Dewey definiu educação como um "processo" e não um produto, ou seja, um processo de reconstrução ou reconstituição da experiência, dando-lhe um valor mais socializado, por aumento da eficiência individual. Até então, era entendido que a educação começava quando a criança entrava na escola e cessava quando dela saia, mas de acordo com esta nova visão de Dewey, a educação se inicia logo com o nascimento de uma criança, e continua ao longo de toda a sua vida, corrigindo o postulado então aceito que a educação ensinava para a vida, pois segundo ele, a educação é vida. Cf. Eby (1976).
} 
instituição essencial à sociedade e não apenas um recurso temporário, mas uma necessidade absoluta para socializar os indivíduos, fornecendo um ambiente social em que as atividades reais, vitais e significativas para a raça fossem simplificadas, purificadas e equilibradas.

Também foi significativa a contribuição de Dewey ao inovar e modificar a filosofia educacional, rebelando-se contra os currículos fragmentados e divididos em matérias, demonstrando que nada na natureza se assemelha ao regime de compartimentação e de conhecimentos estanques como estabelecido nos currículos tradicionais, afirmando que estas subdivisões foram realizadas pela lógica dos adultos, que dividiram o mundo em compartimentos abstratos de conhecimento. Sua filosofia pragmática, conhecida também por instrumentalismo e experimentalismo, prevaleceu por muitos anos em vários países, influenciando currículos, métodos de ensino e os aspectos sociais da educação, inclusive na Europa, Ásia e na América do Sul, e em especial, no Brasil do século XX. Para Dewey,

A educação não é, de modo algum, uma questão trivial que pode ser relegada a mulheres idosas e amas. É um processo social indispensável, um meio para continuidade e progresso ordenados da sociedade humana. Toda a educação deve realizar-se pela participação do indivíduo nas atividades e objetos da sociedade. É um processo pelo qual a civilização é preservada e levada avante em suas tentativas de se completar. A educação é, por conseguinte, a mais fecunda de todas as atividades da sociedade. (EBY, 1976, p.536)

Segundo sua teoria, que modificou radicalmente os processos educacionais a partir do século XX, a mente, em todos os seus aspectos - pensar, sentir, querer, é uma ferramenta ou um instrumento de grande eficiência com a qual o homem se elevou acima das demais criaturas da natureza. Sob esta lógica, o conhecimento não é algo à parte da mente, pois "as idéias são formas ou atividades da mente, que são desenvolvidas e retidas pelo indivíduo para auxiliá-lo a controlar os objetos do meio ambiente e evitar a dor ou proporcionar satisfação" (EBY, 1976, p.533).

Dewey preconizava que a educação era um processo decorrente da evolução das relações humanas e das sociedades como um todo (esta entendida como sendo uma união orgânica de indivíduos), pois a própria existência humana muda de instante a instante, novas situações são enfrentadas e para cada mudança nas condições ou no meio ambiente, novos problemas surgem, que por sua vez, exigem novas soluções dentro das novas condições. Para o autor, Dewey demonstrou que 
O objetivo da educação é encontrado dentro do próprio processo e não como um fim ulterior a ser atingido; ou melhor, pode-se dizer que o objetivo é sempre o fim ou propósito específico que está imediatamente diante da atenção e produz o pensamento e a atividade. A educação procede refazendo constantemente a experiência, e é esta reconstrução que constitui o seu valor e concretiza seu objetivo. Como um processo de revisão e reorganização contínua da experiência, a educação está sempre avançando para a atividade e revisão posteriores. (EBY, 1976, p.537)

Além das inovações de Dewey na esfera psico-social, muitos pensadores do final do século XIX e início do século XX tiveram influências significativas na educação, como Émile Durkheim (1858-1917) que tratou a educação no aspecto sociológico; Giovanni Gentile (1875-1944) nos aspectos filosófico e político; Georg Kerschensteiner (1859-1932) nos aspectos axiológico e cultural, bem como o biologista Aléxis Carrel (1873-1944) e o escritor e crítico Aldous Huxley (1894-1963), neto de Thomas Huxley. Também pode ser destacado Willian James (1842-1910) e seus trabalhos na esfera do aspecto psicológico na educação, para quem

a educação deve ser definida como a organização dos recursos dos seres humanos, isto é, organização dos hábitos adquiridos e das tendências à ação. Noutros termos, dado que cada impressão é seguida de uma reação, a educação consiste em produzir reações mais complexas, ou reações substitutivas no lugar das reações inatas primitivas (HUBERT, 1967, p.310).

Contemporâneo de Dewey e dos demais autores e estudiosos citados, Piaget $^{30}$, embora não fosse um educador, representou uma das mais significativas influências na educação ao desenvolver inúmeros estudos científicos na esfera da psicologia do desenvolvimento e a teoria cognitiva, que veio a ser chamada de epistemologia genética. Essencialmente, Piaget mostrou que ao se observar, cuidadosamente, a maneira com que o conhecimento se desenvolve nas crianças, pode-se entender melhor a natureza do conhecimento humano, que evolui, progressivamente, por meio de estruturas de raciocínio, substituindo umas às outras por meio de estágios, ou seja, a lógica e as formas de pensar de uma criança, são completamente diferentes da lógica dos adultos. Esta descoberta levou-o a recomendar que os adultos e professores adotassem uma abordagem educacional diferente no trato com as crianças, modificando a teoria pedagógica tradicional que,

\footnotetext{
${ }^{30}$ Jean Piaget nasceu em Neuchâtel, Suiça em 1896 e faleceu em 1980. Mesmo sendo biólogo de formação, após obter o título de Doutor em Biologia, em 1918 Piaget foi para Zurich, onde trabalhou como psicólogo experimental, tendo freqüentado aulas lecionadas por Jung e trabalhado como psiquiatra em uma clínica, experiências que tiveram profundas influencias em seu trabalho posterior, quando passou a combinar a psicologia experimental - que é um estudo formal e sistemático - com métodos informais de psicologia: entrevistas, conversas e análises de pacientes. Com isto, se transformou em um eminente psicólogo e filósofo, tendo escrito mais de cinqüenta livros e monografias e publicado centenas de artigos. Estudou a evolução do pensamento até a adolescência, procurando entender os mecanismos mentais que o indivíduo utiliza para captar o mundo. Como epistemólogo, investigou o processo de construção do conhecimento, sendo que nos últimos anos de sua vida centrou seus estudos no pensamento lógicomatemático.
} 
até então, afirmava que a mente de uma criança é vazia, esperando ser preenchida por conhecimento.

$\mathrm{Na}$ visão de Piaget, as crianças são as próprias construtoras ativas do conhecimento, constantemente criando e testando suas teorias sobre o mundo, e, apesar da teoria do conhecimento construída por Piaget não ter intenção pedagógica, ofereceu aos educadores, importantes princípios para orientar sua prática. Ressaltou a importância das competências docentes para o exercício desta profissão, reforçando a idéia de que estas competências, devem respeitar as condições dos alunos, possibilitando um aprendizado humanizado a partir das produções de sentido estabelecidas no processo educacional.

A passagem do final do século XIX para o século XX ainda foi extremamente profícua no desenvolvimento de novas teorias na área da educação, fazendo com que os professores passassem por significativas modificações em suas práticas pedagógicas. Impulsionado pela revolução industrial, houve grande deslocamento de contingentes populacionais da área rural para a área urbana das cidades, provocando elevação da demanda de serviços e de infraestrutura, para as quais elas não estavam preparadas. Além disso, a mudança do paradigma da produção impôs a necessidade de escolarização dos novos trabalhadores, mesmo que em níveis elementares, para fazer frente aos novos aparatos mecanizados, o que repercutiu no aumento do número de escolas em todos os países em processo de industrialização. Este "tumulto" ocasionou grande inquietude no pensamento pedagógico da época, devido às profundas divergências entre as doutrinas educacionais vigentes e os novos pensamentos e conceitos, reforçados pelas transformações sociais que repercutiram em uma renovação pedagógica radical.

Com efeito, a educação antiga, baseada nas relações sociais de outrora, estava adaptada à uma estrutura social que separava, claramente, o ensino para as classes nobres, voltado para o comando, relegando o ensino de massas a condições inferiores e voltada, apenas, para a domesticação das massas, ou seja, para obediência e execução. A educação,

durante longos séculos, na verdade, mal se ocupou da última, e deixou as coisas entregues à transmissão empírica das práticas profissionais. A revolução científica e tecnológica, por um lado e, por outro lado, a revolução política, subverteram esse estado de coisas. O problema reside hoje em conceber um sistema de educação válido para todo um povo e capaz de preparar o homem, a um tempo para sua tarefa técnica e para a sua tarefa cívica (HUBERT, 1967, p.359). 
As divergências entre as doutrinas pedagógicas culminaram no movimento voltado para o desenvolvimento da escola de massas, chamado Educação Nova, que resultou na profissionalização do professorado acompanhada de políticas de normatização e de controle estatal, fortemente disciplinante, para os professores, transformando-os em agentes dos novos projetos sociais e políticos da modernidade (NÓVOA, 1995, p.22). No entanto, estas modificações não implicaram na modificação do processo e das práticas de ensino, nas quais foram mantidas e, até de certa forma, ampliadas as diretrizes emanadas em 1599 pela Ratio atque Institutio Studiorum e a cientificidade na educação.

Neste sentido, o conjunto de processos que envolveu a estatização, a profissionalização e a cientificação, desenvolveu uma estrutura de ensino que perdurou até a década de 60 do século passado, quando suas principais teses passaram a ser contestadas por novos movimentos críticos. Na medida em que a expansão do ensino não conduziu à sua democratização, mas ao contrário, criou novas formas de discriminação e exclusão social, os professores passaram a ser vistos como sendo apenas responsáveis pela manutenção de um ensino fundamentado na reprodução, fazendo com que a profissão docente mergulhasse em nova crise de identidade que perdura até a atualidade, principalmente em decorrência da racionalização do ensino e da proletarização da profissão docente. Segundo Nóvoa (1998, p.27),

A racionalização do ensino e a proletarização do professorado são dois momentos de um mesmo processo de controle externo da profissão docente, de um processo que tem na retórica da privatização do ensino que implica um controle dos professores pelos "clientes" - a sua face mais visível nos dias de hoje.

A proletarização está relacionada à crescente intensificação do trabalho docente pelo acúmulo de tarefas diárias e pela sobrecarga permanente de atividades, aliadas à introdução de sistemas administrativos de avaliação externa e interna, decorrentes da lógica economicista que analisa esta profissão, apenas sob critérios tecnicistas e de produtividade.

Estas condições fazem com que as competências dos docentes estacionem, deixem de ser recuperadas, reconstruídas, ressaltadas e mesmo revaloradas, provocando a ausência de estímulos extrínsecos para realimentar o crescimento do professor em seu processo educacional, uma vez que ele não é apenas ator, mas igualmente sujeito da ação pedagógica, transformando-o de educador 
em um "transferidor de conhecimentos". No entanto, conforme colocado por Paulo Freire (1998, p.46),

Se somos educadores, somos políticos. Se somos educadores e portanto políticos, temos de ter certeza com relação à nossa opção. Enquanto educadores, o nosso sonho não é pedagógico, mas político. As formas de trabalhar - os métodos, etc. - têm muito de pedagógico, mas são eminentemente políticos.(...) Uma das grandes invenções das mulheres e dos homens, ao longo da história, foi exatamente transformar a vida em existência, e a existência não se faria jamais sem a linguagem, sem produção de conhecimento, sem transformação. Mas jamais com a transferência de conhecimento. Conhecimento não se transfere, se discute.

Canário (2000) coloca que no decorrer do século XX, a educação pode ser vista sob a ótica de três modelos de educação, sendo a primeira denominada de "escola da certeza", que perdurou até a metade do século, seguido da "escola das promessas", englobando o período entre o final da $2^{2}$ Guerra Mundial até o final dos anos 60, e a atual, que pode ser denominada de "escola das incertezas". Enquanto a escola das certezas era responsável pela formação do cidadão nacional (época em que as nações-estado estavam em desenvolvimento e o sistema de produção capitalista estava aliado à justiça social mais presente), sendo vista como socialmente justa em um mundo injusto, a escola das promessas passou a ser encarada como injusta em um mundo injusto, prometendo que a educação seria capaz de proporcionar elevação social e distribuir equitativamente entre seus participantes as melhorias ocorridas. No final dos anos 70 , em decorrência da falência do sistema de produção gerada pela mundialização e os problemas surgidos desta situação, foi instalada a sensação crescente das incertezas, com a escola vista injusta em um mundo injusto e sem possibilidade de modificação, contribuindo para o acirramento das diferenças sociais mais gritantes. 



\section{III - A TRAJETÓRIA DA EDUCAÇÃO BRASILEIRA}

Conforme visto no capítulo anterior, a Europa nos séculos XV e XVI vivenciou momentos de profundas revoluções ${ }^{31}$, desencadeando o evento das grandes navegações que levaram ao descobrimento do Novo Mundo e de novo caminho para as Índias.

O descobrimento do Brasil surgiu, portanto, da necessidade de atender às demandas do novo modo de produção e de trabalho, fornecendo matéria-prima e ainda garantindo um posicionamento político e econômico de Portugal junto aos países europeus. A questão educacional apareceria como pano de fundo no sentido de possibilitar a reprodução do que já existia e ainda para impor e manter a cultura européia.

Eby (1976, p.197), referindo-se aos primórdios educacionais no Novo Mundo, afirma que "era natural que os colonizadores do Novo Mundo desejassem estabelecer nas colônias o tipo de educação que consideravam melhor no Velho." Segundo Romanelli (2002, p.21),

no colonialismo, iniciado na Idade Moderna, as trocas culturais se fizeram das mais diferentes formas. No que toca o Novo Mundo, elas foram aniqüiladoras das culturas indígenas (...) O que em verdade ocorreu foi uma transferência pura e simples dos padrões culturais europeus para as terras das Américas.

Neste mesmo sentido, Paiva (2003, p.44) relata que os colonizadores portugueses possuíam uma única visão de sociedade, que era a sua própria e a usavam como modelo para se relacionar com as demais culturas. Ainda segundo o

\footnotetext{
${ }^{31}$ Entre os fatos relevantes passados na Europa, estão a Reforma Protestante; o Renascimento dos antigos padrões de cultura greco-romanas e novos campos de exploração para as ciências; a formação dos Estados Nacionais, das monarquias absolutas que, substituindo pelo poder central a força dos senhores feudais, constituiu os Estados modernos; o desenvolvimento constante do capitalismo por meio da difusão do grande comércio que se manifestou pela fundação de numerosas casas de negócios. Houve o desenvolvimento das indústrias principalmente extrativas e metalúrgicas, a fundação de mercados novos, modificando o regime de trabalho, agora, livre da influência dos patrões, portanto o trabalho passa a ser por conta própria e risco do trabalhador. Larousse (1998).
} 
mesmo autor, "a sociedade portuguesa tinha uma estrutura rígida, centrada na hierarquia, fundada na religião", na qual "a hierarquia e religião eram consideradas princípios inadiáveis em qualquer situação."

Tobias (1986, p.26), referindo-se à história da educação no Brasil, afirma que

O Brasil, país virgem e de indígenas, para poder dispor de uma História da Educação, tem que lançar raízes muito mais longe do que o Rio de Janeiro, ou São Paulo, ou Bahia. O historiador e o pensador têm, de um lado, que mergulhar sertão adentro e, de outro lado, que olhar a Europa de 1500, o único mundo civilizado e culto, o único mundo de gente, de então, sendo o restante do universo considerado bárbaro.

Por outro lado, o índio brasileiro até o descobrimento do Brasil, vivia conforme sua cultura, inclusive com relação à educação que era empírica e transmitida através das gerações, pois "a escola era o mato; muito mais importantes as lições do exemplo do que as palavras." (id,ibid).

A cultura européia era considerada super-refinada, impregnada de certos mitos, os quais influenciaram profundamente a educação dos primeiros brancos que vieram viver na colônia. Segundo o mesmo autor, "desses diversos mitos, o de super-homem europeu e o do homem-inferior, índio ou negro, marcaram indelevelmente a vida e a educação do Brasil." (idem, p.29)

Nestes primeiros momentos de colonização, o único comportamento possível para atingir os objetivos propostos (descobrir e transportar para Portugal as riquezas naturais, especialmente ouro, madeira e outros insumos) foi a imposição. Dessa forma, desde a "descoberta" do Brasil e por volta dos cem anos seguintes, os portugueses viveram em guerra contra os nativos, com a intenção de tomarIhes as terras e extrair-Ihes as riquezas naturais e para tanto, sujeitando os nativos ao trabalho escravo.

Neste período, as ameaças para os colonizadores eram constantes sob dois pontos de vista: o da segurança, e o da cultura, uma vez que o número de nativos era em número muito maior que o de portugueses ${ }^{32}$.

A educação aparece na história do Brasil, a partir da chegada dos jesuítas, que vêm para a então colônia com a missão de cumprir o mandato real de conversão dos índios e dar apoio religioso aos colonos, preservando, de certa forma, a cultura portuguesa.

\footnotetext{
${ }^{32} \mathrm{Cf}$. TOBIAS (1986) e PAIVA (2003).
} 
A primeira expedição jesuítica enviada de Portugal ao Brasil chegou em 1549 em companhia do Governador Geral Tomé de Souza aportando em Salvador, quando, de pronto, foi providenciada a fundação do Colégio da Bahia ${ }^{33}$ para possibilitar a continuidade dos estudos dos familiares portugueses. Com a vinda de outras expedições, os jesuítas se espalharam ao longo da costa litorânea do Brasil.

Sob o ponto de vista da cultura, o Brasil era visto pelos jesuítas como "terras virgens", prontas para o trabalho educacional e catequético. Os índios e filhos dos primeiros portugueses foram "educados" livres, pois ali não existiam os preconceitos filosóficos, as idéias heréticas, nem as lutas com outras ordens religiosas. Sob a ótica pedagógica, o ensino praticado pelos jesuítas era voltado para dar rudimentos de leitura e escrita a naturais e colonos, bem como para o ensino profissional restrito, isto é, somente eram permitidas aulas dos ofícios de tecelão, ferreiro, sapateiro, pedreiro, evitando-se com isso, o desenvolvimento da colônia.

Em 1552, o Brasil contava com as primeiras escolas de ensino elementar em São Salvador, Espírito Santo e São Vicente, contudo muitas eram as dificuldades em outras partes do país e o cenário da educação era precário e desolador. Segundo Tobias (1986, p.44), isto acontecia "tanto por falta de professores, de prédios escolares, de móveis e de um mínimo de conforto quanto por causa do ambiente, dos pais e parentes, em geral sem cultura e desprovidos de compreensão para o papel do educador e para a importância da educação". Esta precariedade de condições, continua o autor, foi relatada pelo Padre Anchieta em carta enviada a Inácio de Loyola, descrevendo que:

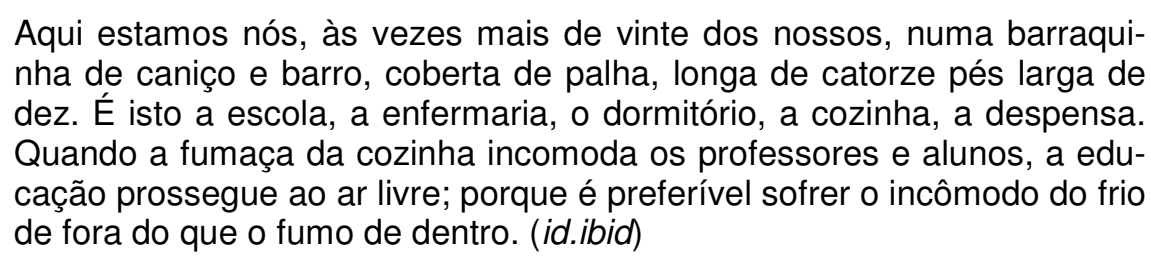

Conforme o autor, como neste período a remuneração dos jesuítas era feita diretamente pela Coroa Real Portuguesa, o magistério oficial da educação brasileira era gratuito e estava sob domínio dos padres da Companhia de Jesus nos seus três graus: ensino popular, ensino médio e ensino superior, com exceção da formação de padres nos seminários, que eram remunerados.

\footnotetext{
${ }^{33}$ Colégio é considerado aqui na acepção de residência ou casa de jesuítas.
} 
Tanto no Brasil como na Europa, os jesuítas seguiam as normas padronizadas na Ratio atqe Studiorum, ${ }^{34}$ porém adaptadas ao nosso país, tendo como exemplo, a inclusão da língua tupi-guarani no currículo, para facilitar a catequese dos índios. No entanto, destaca Cunha (1989), ao contrário da Espanha, que instalou universidades nas colônias americanas no século XVI, Portugal proibiu estas instituições no Brasil Colônia, fornecendo bolsas para alguns filhos de colonos na Universidade de Coimbra.

A educação cristã pelos jesuítas tinha como finalidade preparar missionários e padres para esta Ordem. Inicialmente os subsídios que recebiam os jesuítas eram para sua própria sustentação e para a formação daqueles que, no futuro, os substituíssem. Entretanto, esta primeira parte de educação brasileira, pelos jesuítas, compreende dois períodos distintos, sendo o primeiro, representado pelo Padre Manuel da Nóbrega, que defendia o ensino cristão, universalizador e de espírito democrático, estendendo-se até 1580. O segundo período da educação, iniciado após a morte do Padre Manuel da Nóbrega em 1570, derivou das imposições e determinações das autoridades jesuíticas da Metrópole e foi caracterizada por ser segregadora do índio e do pobre.

Referindo-se aos índios, Leite apud Tobias (1986, p.47), afirma que "a princípio se julgou serem tão aptos como os naturais das Índias Orientais e do Japão, donde chegavam a Portugal, informações maravilhosas". Tratava-se de uma comparação entre as culturas Orientais e do Japão com a do Brasil, sendo esta última considerada um ambiente inculto. O mesmo autor, na obra citada conclui que: "O desnível de cultura entre os habitantes das cidades do Oriente e os fiIhos das florestas do Brasil tornava impossível a imediata elevação destes a estudos superiores e a chefes e guias de cristãos" .

Assim, depois de Nóbrega, os índios e mais tarde os negros, os pobres e os pardos foram alijados e segregados do direito e dos benefícios da escola brasileira, não podendo estudar latim nem se tornarem padres. Este acontecimento é considerado "o primeiro grande triunfo da aristocratização no ensino do Brasil" (TOBIAS, 1986, p.48). Os alunos que freqüentavam os colégios eram filhos de

\footnotetext{
${ }^{34}$ A Ratio Studiorum atqe Institutio Societatis constituia-se em um conjunto de regras e planos que deveriam ser observados pelos componentes da Companhia de Jesus, englobando inúmeras ações e atitudes (tais como a fixação da divisão de classes por sexo, regime de atividades pedagógicas, normas administrativas, modos de vestir, posturas de mãos, ênfase à oralidade, competição, emulação), que teve elaboração demorada, tendo sido consagrada somente em 1599. É muito importante destacar que este modelo de escola transformou completamente a educação e persiste até hoje, tendo sido apropriado e "renovado" pelo sistema de produção capitalista como elemento de docilização e reprodução ao fixar tempos específicos para o desenvolvimento de tarefas, estabelecer profunda estratificação curricular e preconizar repetição continuada para a transmissão de saberes já constituídos, e concentrando um maior número de alunos na mesma sala, finalizando por provocar a pauperização do professor. Cf. França (1952).
} 
senhores de engenho, de funcionários públicos, de criadores de gado e de oficiais mecânicos, caracterizando-se o caráter discricionário desta época da nossa educação.

Outros dois acontecimentos de relevância no país conduzem à transformação da educação democrática e brasileira em elitizante e metropolitana: o ensino profissionalizante criado e desenvolvido por Nóbrega foi suprimido (e a este respeito surgiu a vergonha e a mentalidade de que os cursos profissionalizante e técnico eram para gente inferior e escrava). Outro acontecimento foi que, todos os imóveis pertencentes às Confrarias passaram para o nome e mãos da Companhia de Jesus armando-se um esquema que, posteriormente, seria fundamental para o jogo político que mudaria o rumo da educação no Brasil, pelas mãos do Marquês de Pombal.

Nesta época, o direito à educação cabia apenas a um limitado número de pessoas que pertenciam à classe dominante e ainda assim, eram excluídos os fiIhos primogênitos (que assumiam os negócios da família) e as mulheres (em números bem menores), que recebiam os ensinamentos rudimentares na própria casa.

Os objetivos práticos das ações dos jesuítas foram pouco a pouco se concretizando, ou seja, a catequese da população indígena por meio de escolas elementares para "curumins", a criação de centros missionários junto aos indígenas e a fundação dos Colégios para exercício dos futuros sacerdotes que deveriam servir a Ordem, cujo conteúdo eram o ensino das ciências humanas, as letras e as ciências teológicas. Cabe ressaltar que os Colégios selecionavam apenas os homens pertencentes à camada dominante da sociedade brasileira.

Segundo Romanelli (2002, p.37), “a parte da população escolar que não seguia a carreira eclesiástica encaminhava-se para a Europa, a fim de completar os estudos, principalmente na universidade de Coimbra, de onde deviam voltar letrados".

A educação jesuítica não contribuiu com modificações estruturais na vida social e política do Brasil na época, pois, imbuídos do espírito da contra-reforma, eram avessos aos estudos das ciências e da liberdade do pensamento. Assim, cuidaram de ministrar a cultura geral básica, sem qualificação para o trabalho, porém adeptos da rígida disciplina e do princípio da autoridade. 
$\mathrm{Na}$ construção da sociedade nascente, entretanto a instrução em si não possuía grande representação, pois não se exigia preparo para as atividades produtivas pela sua administração e tampouco da mão de obra.

Para Romanelli (op.cit, p.34), "o ensino, assim, foi conservado à margem, sem utilidade prática visível para uma economia fundada na agricultura rudimentar e no trabalho escravo."

A educação jesuítica estava organizada da seguinte forma: o curso elementar, constituído pelo ensino das primeiras letras que compreendia ler escrever e contar, e da doutrina religiosa; com duração de um ano. O curso de humanidades compreendia o ensino de gramática, retórica e das humanidades; tinha a duração de dois anos e era ensinado em latim. Como já foi citado o tupi-guarani substituiu o grego e o hebraico, previstos na Ratio Studiorum.

O curso de artes $^{35}$ que também era conhecido como curso de ciências naturais ou de filosofia, tinha a duração de três anos e conferia os graus de bacharel e licenciado com um mesmo conteúdo, compreendendo o ensino de lógica, física, matemática, ética e metafísica. A diferença entre os graus, segundo Cunha (1986), "estava no número de pessoas que compunham a banca examinadora: três para bacharéis e cinco para os licenciados, estes os que pretendiam exercer o magistério" ${ }^{36}$

O curso de teologia conferia o grau de doutor e tinha a duração de quatro anos, com duas matérias essenciais: a teologia moral que se ocupava das questões éticas do cotidiano e a teologia especulativa, que consistia no estudo do dogma católico.

O objetivo inicial dos jesuítas, a catequese, foi sendo gradativamente substituído em grau de importância, para a educação da elite. Azevedo (apud Romanelli, 2002, p.36) afirma que

já não era somente pela propriedade da terra e pelo número de escravos que se media a importância ou se avaliava a situação social dos colonos: os graus de bacharel e os de mestre em artes (dados pelos colégios)

\footnotetext{
${ }^{35} \mathrm{O}$ curso de artes do Colégio da Bahia possuía conteúdo idêntico ao Colégio de Évora, também dirigido pelos jesuítas e consistia em conteúdo preliminares para ingressarem nos cursos de medicina, direito, cânones e teologia da universidade de Coimbra, entretanto, o ingresso automático para esses cursos era válido somente para os que estudavam em Évora. No Brasil, os graduados em artes na Bahia, eram obrigados a repetir o curso em Coimbra ou prestarem exames de equivalência. Decorreu deste fato, na segunda metade do Século XVII um processo de reivindicação para trazer para o colégio da Bahia, os privilégios do Colégio de Évora iniciando um movimento pró-universidade no Brasil derivado também, do contínuo povoamento, da expansão das riquezas e ambição dos pais que desejavam formar seus filhos Cf. Cunha (1986).

${ }^{36}$ É interessante destacar que vários preceitos estabelecidos pela Ratio Studiorum em 1599 ainda permanecem em vigor, mesmo sem que se saiba claramente este fato. Por exemplo, veja-se a conformação das bancas examinadoras, mantidas até hoje no caso de níveis de mestrado e doutorado, além das geometrias das salas de aulas e o período de arquivamento das provas realizadas pelos alunos por 5 anos, todas elas estabelecidas como normas neste documento jesuítico.
} 
passaram a exercer o papel de escada ou de ascensor, na hierarquia social da Colônia, onde se constituiu uma pequena aristocracia de letrados, futuros teólogos, padres-mestres, juizes e magistrados .

Este modelo de educação aristocrático e livresco, continua a autora, contribuiu na construção das estruturas de poder na Colônia, pois a classe dominante foi se conscientizando do poder desse modelo de educação, na formação de seus representantes políticos junto ao poder público.

Desde o descobrimento do Brasil e até 1759, os jesuítas haviam montado um aparato escolar de característica nitidamente profissional, ou seja, para a preparação de novos clérigos e integrantes da Companhia de Jesus, composto por escolas que não eram nem públicas e nem se destinavam ao ensino propriamente dito, fortemente elitistas, de tal forma que com exceção dos brancos nativos, os mamelucos, negros e mulatos jamais tiveram acesso à elas.

O Reino Português entrou em decadência econômica, com a queda da mineração e com um atraso cultural oriundo, entre outros fatores, do fanatismo religioso, provocando o surgimento de um clima de insatisfação com relação aos jesuítas na Metrópole. Na Colônia, a insatisfação e os atritos entre os jesuítas e a população pela escravização dos indígenas também eram notórios e tanto em Portugal quanto na Colônia, foram introduzidas as idéias provindas do enciclopedismo que eram explicitamente anticlericais. Desta forma, Portugal passou por períodos de intensa transformação política, econômica e cultural, que conseqüentemente, repercutiram no Brasil ${ }^{37}$.

Em 1750, Sebastião José de Carvalho, posteriormente elevado ao título de "Marquês de Pombal", foi nomeado Ministro do Rei com a intenção de manter unida a corte que se encontrava dividida em duas facções devido às relações conflituosas entre nobres, misturadas com as relações entre as ordens religiosas e com isso enfrentar a crise econômica instalada.

Um atentado frustrado à vida do Rei em 1758, realizado pela facção que não concordou com as medidas impostas para a ampliação do poder do Estado, provocou a repressão ao partido dominado e a luta dos seus aliados, especialmente a Companhia de Jesus, culminando, em 1759, na expulsão dos jesuítas de Portugal e do Brasil sendo seus bens tomados pela coroa ${ }^{38}$.

A expulsão dos jesuítas, segundo Romanelli (2002, p.36) gerou um desabamento na estrutura do ensino, com o que "a uniformidade da ação pedagógica,

\footnotetext{
${ }^{37}$ Cf. Cunha (1986).

${ }^{38} \mathrm{Na}$ época da expulsão, os jesuítas possuíam 17 colégios e seminários, 36 missões e 25 residências. Cf.Tobias (1986).
} 
a perfeita transição de um nível escolar para outro, a graduação, foram substituídas pela diversificação das disciplinas isoladas e leigos começaram a ser introduzidos no ensino", conduzindo o Estado a assumir os encargos da educação. Notase assim que as diferenças entre o ensino das metrópoles e colônias espanholas e inglesas com relação às portuguesas se aprofundam, inclusive com relação aos primeiros professores leigos (não religiosos) brasileiros, totalmente sem preparo, inicial, para as funções docentes.

Em Portugal, cinco meses após a expulsão da Companhia de Jesus, Pombal publica o "Alvará de 28 de junho de 1759", determinando a extinção e o fechamento dos colégios jesuítas, tanto em Portugal quanto nas Colônias de UItramar, o que se configurou em um repúdio aberto, ao método de ensino jesuítico e aos compêndios que a Companhia usava, exigindo-se outros métodos e outros compêndios. Nesta reforma promovida por Pombal, enquanto em Portugal o foco principal fora o ensino superior, no Brasil, pela total ausência de ensino superior, a reforma se constituiu na pura e simples eliminação do sistema educacional jesuítico, sem quase nada ser proposto em seu lugar, o que trouxe repercussões importantes e negativas para a então Colônia, que ficou totalmente desprovida em termos de educação.

Nesta ocasião, é criado o lugar de Diretor-Geral dos Estudos (equivalente ao atual cargo de Ministro de Educação), cuja função emergente foi a de conseguir professores para as classes, cabendo-lhe também, as funções de vigiar e averiguar o progresso dos estudos, apresentando um relatório anual da situação do ensino. Como em tantas outras questões originadas nesta Reforma imposta por Pombal, o desmantelamento da estrutura educacional fez com este cargo fosse ocupado apenas em 1799, quando foi permitido que o Vice-Rei do Brasil nomeasse um professor para visitar as aulas e informar Portugal sobre a situação da educação brasileira, iniciando-se a supervisão do ensino brasileiro.

Introduziram-se também as "aulas régias" ou aulas avulsas de latim, de grego e de retórica, aulas essas que deveriam substituir as disciplinas até então oferecidas nos extintos colégios jesuítas e que passaram a ser mantidas pela Coroa. Para sua viabilização foi instituído em 1772, um imposto denominado "subsídio literário".

A situação de abandono do ensino no Brasil pode ser comprovada nos textos das únicas quatro cartas enviadas ao Brasil pelo Marquês de Pombal, nas quais, conforme Tobias (1986), ele deixa claro que suas preocupações e todas as 
suas instruções são exclusivamente de ordem militar, sem qualquer observação de cunho pedagógico ou educacional, apenas preocupações de ordem econômica e operacional no sentido de transferir bens e insumos da colônia para Portugal.

Em decorrência destas medidas, a expulsão dos jesuítas resultou na paralisação total das atividades educacionais no Brasil e como a metrópole pouco se interessava em equipar a colônia com um sistema educacional eficiente, a educação colonial ficou reduzida a algumas poucas escolas e aulas régias. Nem mesmo o Diretor-Geral de Estudos e os subsídios literários foram suficientes para levantar recursos e impedir a insuficiência das escolas em quantidade e qualidade de ensino.

Saviani (2004, p.17) afirma que as reformas pombalinas se opuseram às idéias religiosas "e, com base nas idéias laicas inspiradas no lluminismo, instituem o privilégio do Estado em matéria de instrução, surgindo, assim, a nossa versão da educação pública estatal." Neste período, a responsabilidade do Estado restringia-se às diretrizes curriculares da matéria a ser ensinada e ao pagamento dos professores. Aos professores, segundo o autor, cabia a provisão das condições materiais para o local de ensino (era freqüente este local ser a própria casa do professor) bem como sua infra-estrutura e ainda, os recursos pedagógicos a serem utilizados no desenvolvimento do ensino.

Tobias (1986, p.97) refere que sem os jesuítas e abandonados pela promessa da reforma do ensino proposta por Pombal, os professores disponíveis (uma vez ausentes os jesuítas), eram leigos ou não, professores improvisados, considerados sobras de outras profissões e ainda, indicados pelos bispos ou pelos padres. Em determinadas ocasiões, estes professores eram os próprios padres ou capelães de engenho.

Assim, apesar da expulsão oficial, a filosofia da educação jesuítica seguiu de maneira eficaz, uma vez que os padres, capelães de engenho e professores leigos, considerados os docentes daquela época, eram fruto da educação jesuítica, já arraigada na sociedade colonial.

Neste período da reforma pombalina, até 1799, o ensino encontrava-se como já apontamos, sem sistematização, sem freqüência definida, sem pessoal docente em quantidade e qualidade suficientes quando, licenças para docentes, passaram a ser concedidas pelo vice-rei do Brasil. No entanto, a aristocratização do ensino no Brasil já havia sido desencadeada e agora, com a Reforma imposta pelo Marquês de Pombal, fora institucionalizada. 
Segundo Tobias (1986, p.99) "a pobreza do Brasil, a falta de faculdades e de escolas normais para a formação de professores, a raridade de mestres capacitados, a remuneração ofensiva dos professores" constituíram fatores ponderáveis para a aristocratização, mas, foram considerados fatores externos da estrutura do ensino. Contudo, para a filosofia da educação de Pombal o ideal da escola brasileira passa a ser o ideal estrangeiro, ou seja, formar o nobre português. Nestas condições, a escola não era propensa a formar nas profissões técnicas, agrícolas, nem tampouco formar o brasileiro, mas sim aqueles que dispunham de uma condição financeira privilegiada, ou seja, os nobres.

Assim, o curso médio só teria sentido se o aluno quisesse continuar na Universidade, de tal forma que a estrutura do ensino médio tornou-se isolada, elitista e veementemente assentada no poder econômico do indivíduo, tendo sido estabelecidas as bases que permeiam o sistema educacional brasileiro até os dias de hoje e, para o mesmo autor,

\begin{abstract}
o mesmo espírito, a mesma filosofia da educação, que descia da universidade de Coimbra, impondo-se no ensino médio brasileiro, aristocratizando-o, estrangulando-o, também se instalou no ensino elementar que, em vez de ser preparado para a vida, em vez de estar encharcado de sabor do Brasil, tornou-se exclusivamente o primeiro degrau de preparação para a Universidade de Coimbra e para o ensino superior. Não constituía um "cursinho", que é algo fora da lei e da estrutura oficial do ensino brasileiro; era algo pior, pois se radicava numa instituição legal e perfeitamente dentro da estrutura do ensino brasileiro; era o fundamento da educação nacional que, assim basicamente transformava em privilégio de minoria rica, economicamente falando. Era, já no primário, o início da aristocratização do ensino e da escola do Brasil (op.cit; p.100).
\end{abstract}

De forma resumida, pode-se entender, portanto, que os cerca de 300 anos iniciais da história do Brasil, em todos os aspectos inclusive educacionais, podem ser divididos entre a atuação de duas "companhias"39. No período de 1549 até 1759, a Companhia de Jesus foi responsável pelo monopólio da educação, realizando-a de maneira confessional e específica (educação jesuítica), impedindo um ensino popular similar ao implantado nos Estados Unidos da América. Após a saída dos jesuítas, inicia-se em 1759, o predomínio da Companhia Geral de Comércio do Brasil e suas sucessoras, voltadas para a manutenção do sistema produtivo extrativista, evitando a independência da colônia, observando-se

\footnotetext{
${ }^{39}$ Companhia era uma organização privada à qual o Rei cedia poderes de empresa pública autônoma, nos moldes das atuais fundações.
} 
que de 1759 a 1782 foi proibida a implantação de qualquer forma de escola no Brasil.

A vinda da Família Real Portuguesa em 24 de Janeiro de 1808 e o decreto real de abertura dos portos de 28 de Janeiro representaram o fim do monopólio que a Companhia de Comércio e Navegação exercia no Brasil Colônia até então, possibilitando o início do comércio com o mundo exterior.

No entanto, a situação na esfera educacional, continuava nos mesmos moldes anteriores, ou seja, o sistema existente era constituído de algumas escolas dispersas pelo reino, com professores despreparados.

Assim é que D. João VI, ciente que o domínio de Napoleão poderia se estender por longo período e visando criar um ambiente similar ao da Corte européia no Rio de Janeiro, elevou o Brasil à condição de Reino Unido e autorizou a implantação de escolas superiores para a formação de profissionais e burocratas, além de militares, em especial na área da engenharia. É importante salientar que D.João VI não pretendia com isto, a formação do homem ou do cidadão, mas ao contrário, necessitava apenas dos profissionais que dessem sustentação ao seu domínio, por isso a ênfase dada às escolas militares, para a criação de um sistema de defesa da corte contra eventuais invasões, demonstrando, claramente o fim utilitarista que passa a ter a educação no Brasil.

Neste sentido, D.João VI autorizou ainda em 1.808 a criação da primeira escola superior brasileira, que foi a Escola de Cirurgia e Medicina da Bahia, e em seguida, a criação da Academia Militar e da Academia da Marinha, primeiros estabelecimentos de ensino superior do Brasil. Mais tarde, a Academia Militar transformou-se em Escola Politécnica, enquanto foi autorizada a criação da Escola de Medicina e Cirurgia do Rio de Janeiro, visando prover as necessidades da corte.

D. João VI iniciou, a partir de suas decisões, cartas régias e decretos, inúmeras inaugurações de colégios e implantação de atividades culturais, de tal forma que foi considerado o Restaurador da Educação no Brasil. Assim é que em 1812, foi apresentado pelo General Francisco de Borja Stocker, nomeado pelo Ministro Conde de Barca, o plano de reforma educacional brasileira, fortemente influenciado pela França, estabelecendo a criação de níveis diferenciados de estudos: os pedagogos, similares à escola primária; os institutos, relativos às escolas profissionais médias para formar agricultores, operários e outros; os liceus, para o ensino médio clássico, e as Academias, para as ciências. 
Com efeito, as escolas inicialmente autorizadas formariam militares (para a defesa da Corte), médicos (para cuidar da saúde dos integrantes da Corte e dos militares), e engenheiros militares (para viabilizar a edificação de fortificações de defesa) e não militares (para implantação das obras necessárias à movimentação das tropas e a edificação dos prédios públicos). Seguiram-se ainda os cursos de química (para viabilizar a exploração dos insumos, minérios e materiais de construção) e de agricultura (voltados para a expansão das culturas). Um dos grandes progressos proporcionados por estas atitudes foi a supressão oficial da Ratio atqe Studiorum do panorama da nascente educação brasileira, mesmo que vários de seus preceitos tenham perdurado até os dias atuais.

É importante ressaltar que a aristocratização do ensino no Brasil, até os dias de hoje ainda verificada, foi concretamente definida por D. João VI, a quem somente interessavam as disciplinas práticas, ou seja, aquelas que auxiliavam a formação do engenheiro, do médico, do militar, etc.

Esta situação perdurou até o retorno da Família Real para Portugal, cerca de dez anos depois, e mesmo tendo sido tentado o restabelecimento da condição de colônia para o Brasil, o processo de expansão comercial tornou-se mais significativo, impedindo o retrocesso pretendido pelo império.

Assim, é proclamada a independência da colônia e fundado o Império do Brasil em 1822, iniciando-se uma fase de debates sobre projetos que visavam a estruturação de uma educação nacional. Não se tratava, pois, de apenas a substituição ou a reforma do sistema existente, mas da efetiva criação de um sistema educacional para o Brasil.

A Constituinte de 1823, por meio da Comissão de Instrução Pública produziu dois projetos de leis referentes à Educação Pública: o Projeto do Tratado de Educação para a Mocidade Brasileira e o Projeto de Criação de Universidades.

Segundo Xavier (1992), a sessão aberta em 27 de agosto de 1823 para discussão do projeto de criação de universidades no país, foi iniciada com uma severa crítica à imprecisão com que foram colocados os aspectos fundamentais de sua efetivação, ou seja, os fundos necessários, o regime de provimento de mestres, etc. A primeira discussão assumiu um caráter de disputa regionalista, girando quase que exclusivamente em torno do número e da localização das universidades. Em termos educacionais, a principal construção desta reforma foi a institucionalização do ensino primário gratuito para todos os cidadãos, e posteriormente, a partir de nova revisão desta legislação, a criação de escolas em todas 
as cidades, vilas e lugarejos, inclusive com a divisão de classes para ensino de meninos e meninas, até então ignorada em todas as políticas educacionais anteriores.

Somente em outubro de 1827, foi promulgada uma Lei pela Assembléia Geral Constituinte, permitindo a implantação de escolas de todos os níveis e em todas as províncias, encerrando efetivamente o período de proibição estabelecido por Pombal em 1759, estendendo-se por cerca de 70 anos! Em decorrência desta Lei, em 1827 ocorrem as criações dos Cursos Jurídicos e dos Cursos de Belas Artes, e de dois cursos: de Ciências Jurídicas e Sociais, sendo o primeiro em São Paulo e o segundo em Olinda-Recife.

Conforme Tobias (1986), novas alterações na política nacional ocorreram a partir de 1831, com a abdicação de D. Pedro I, de tal forma que em 1834, com o Ato Adicional à Constituição, foi estabelecida a descentralização do ensino no Brasil, com a transferência para as Assembléias Gerais Provinciais da competência para legislar sobre a instrução pública e sobre os estabelecimentos próprios para executá-la, exceto os relativos às Faculdades de Medicina, Cursos Jurídicos e Academias, então existentes, que foram mantidos sob a esfera central.

Esta descentralização provocou a decadência do ensino público, na medida em que as províncias mais afastadas ficaram desprovidas dos progressos originados nas cidades mais populosas, iniciando-se a projeção do ensino privado e posteriormente, na implantação de inúmeras escolas ligadas a várias ordens da Igreja Católica, inclusive com o retorno dos jesuítas em 1843, quando fundaram entre outros, o Colégio do Desterro em Santa Catarina.

Neste período, o ensino primário regia-se pela Lei Geral do Ensino Elementar (1827), e o papel da União começa a ser de controlador ao invés de mantenedor, resultando em que até o final do Império não foi implantado um sistema escolar efetivo, havendo apenas ações isoladas e pontuais. Assim,

[...] as poucas escolas superiores (profissionais: direito, engenharia, agricultura, química e medicina) e a parca rede de escolas médias estaduais (liceus e escolas normais) atendem apenas, a uma pequena elite rural $\mathrm{e}$ urbana de burocratas ou senhores rurais, ficando o vasto território nacional sem nenhum atendimento escolar, salvo as escolinhas de be-a-bá. (LIMA, 197?, p.109)

A educação nesta época persistia em suas características elitistas, de tal forma que em muitas escolas era vedado o acesso de negros e escravos libertos, demonstrando o grande atraso com relação aos demais países da Europa e da 
América do Norte. Para efeito de comparação, em 1872 os analfabetos representavam cerca de $83 \%$ da população no Brasil, enquanto nos Estados Unidos da América no mesmo ano, a população alfabetizada representava cerca de $85 \%$ da população total. É importante destacar que a criação de universidades no Brasil não era de interesse coletivo. Com efeito, mesmo reconhecendo que o ensino das massas era precário, os liberais entendiam que a criação de uma universidade no país era importante do ponto de vista educacional. Em contrapartida, os positivistas, que constituíam a corrente política mais proeminente, se opunham totalmente à sua criação, por entenderem que o ensino universitário estaria carregado de conteúdos metafísicos, conforme classificação "comteana", que a ciência estaria destinada a substituir (CUNHA, 2003, p.156)

A educação brasileira passa então, por várias modificações, notando-se que o ensino superior ganha timidamente, mais densidade, fruto da economia cafeeira, que demandava maior contingente de técnicos na esfera da construção de estradas de ferro e infra-estrutura para exportação agrícola, favorecendo o ensino das engenharias civil, metalúrgica, entre outras. Este período culmina, já sob o poder de D. Pedro II, na Reforma de Carlos Leôncio de Carvalho, em 1879, que, sob forte influência dos Estados Unidos, decreta ser "completamente livre o ensino primário e secundário no município da Corte e o superior em todo o Império, salvo a inspeção necessária para garantir as condições de higiene e moralidade" criando os fundamentos legais para a existência das faculdades particulares. (TOBIAS, 1986, p.158)

Considerado um conjunto desconexo de normas, sem quase preocupação alguma com a filosofia pedagógica, esta legislação manteve as principais características das anteriores, mantendo-se, assim, pouca valorização da carreira docente, de tal forma que, na visão de Tobias (1986, p.160),

A reforma Leôncio de Carvalho, apesar de suas partes revolucionárias e de seus progressos, apesar de ter durado doze anos até a reforma de Benjamin Constant em 1890, não apresenta unidade profunda, frutificadora em reformas administrativas e pedagógicas. É o legislador e o administrador sem as preocupações filosóficas-educacionais, cientificamente estabelecidas e planejadas. É o protótipo de brasileiro dominado pelo exemplo e pela imitação do estrangeiro, especialmente do país considerado adiantado.

Poucas foram as modificações levadas a efeito no "sistema" educacional do império até a Proclamação da República, quando, por força da explosão do crescimento demográfico e do surgimento de uma classe média (decorrente do fi- 
nal da escravatura e do início da industrialização do país), ocorrem as primeiras reformas no ensino do período republicano, especialmente no âmbito do ensino secundário.

Em 1882, Rui Barbosa apresentou à Câmara dos Deputados o seu parecer sobre a Reforma do Ensino em todos os níveis, sem grandes repercussões, de maneira que até a Proclamação da República, em 1889, foram criados ao todo 14 estabelecimentos de Ensino Superior no Brasil, ou seja, ao contrário do ocorrido em outros países mais evoluídos, a República iniciou com apenas 14 Escolas Superiores em todo o território nacional.

A República, iniciada a partir de um golpe de Estado resultante da conspiração de forças liberais, positivistas e monarquistas ressentidos, mudou a orientação política do país para o regime federativo, atendendo aos interesses da burguesia cafeeira, tendo, no entanto, preservado a centralização do poder central em áreas específicas, especialmente no tocante à educação.

Em 1890, início da República Velha, Benjamim Constant propõe uma reforma do sistema educacional, tendo como base os ideais positivistas, que teve curtíssima duração, pois já em 1901, Epitácio Pessoa inicia nova reformulação, isenta do idealismo da anterior, voltada exclusivamente para o ensino secundário, visando atender aos reclamos da sociedade, criando o ensino "seriado" e a fiscalização do governo central. Um dos aspectos marcantes da sociedade de então, era o grande interesse pelo acesso ao ensino superior, tanto pelas elites latifundiárias quanto pelos trabalhadores, e a facilitação do acesso, estabelecida pela implantação de novas instituições de ensino superior e pelas contínuas e sucessivas mudanças das condições de admissão gerou tensões que desencadearam o crescimento do número de escolas superiores no país. Com base nesta legislação, em 1909 foi criada a Universidade de Manaus, que funcionou até 1926, quando foi fechada, sendo reaberta apenas em 1962.

Passados alguns anos, já em 1911, foi implantada uma nova reforma, sob a direção de Rivadávia Correia a partir do Decreto nํ. 8.659, de 5/4/1911, que também teve duração incipiente (apenas 4 anos), mas que estabeleceu a desregulamentação geral do ensino, com a supressão de qualquer fiscalização, concedendo a plena autonomia estadual e liberando a criação de escolas privadas. En- 
tre outras escolas de diversos níveis, em 1912 foi criada a Universidade do Paraná, sediada em Curitiba, sendo a terceira universidade constituída no país ${ }^{40}$.

Considerada muito liberal, permitindo inclusive a criação de duas universidades privadas ${ }^{41}$ esta legislação transferiu a gestão das escolas superiores à exclusiva deliberação das Congregações, retirando a presença do Estado na gerência do ensino, estabelecendo apenas uma ação fiscalizadora, por intermédio da instância denominada Conselho Superior de Ensino, criado pelo mesmo Decreto. Este liberalismo exacerbado criou uma grande desorganização do sistema educacional, tendo possibilitado o surgimento de forte reação por parte da sociedade, culminando com a Reforma Carlos Maximiliano, já em 1911.

Carlos Maximiliano propôs nova reformulação no ensino, em total contraponto à anterior, retomando o comando da União sobre o ensino, a partir da promulgação da Lei no 2.924, de 5/11/1915 e Decreto nำ11.530, de 18/3/1915, com os quais foi re-oficializada a atividade de ensino superior no país. Entre outras medidas importantes, destaca-se a criação do vestibular como condição de acesso aos cursos superiores e a seriação do ensino, além da proibição do reconhecimento ou equiparação de escolas privadas com as oficiais e a tolerância com os cursos preparatórios. Também autorizou o governo a "quando julgasse oportuno, reunir em universidade". Três faculdades existentes no Rio de Janeiro foram agrupadas em 1920, para a criação da Universidade do Rio de Janeiro, reunidas em torno de urna Reitoria, embora não se pudesse afirmar, que fosse realmente uma universidade, conforme os padrões da Europa e dos Estados Unidos da América $^{42}$. Esta reforma sofreu grandes alterações ao longo de sua vigência, em especial em decorrência da epidemia de gripe espanhola, que levou os dirigentes a permitirem o acesso às faculdades sem exames, por intermédio de decretos.

A partir das profundas diferenças entre as duas reformas anteriores, em 1925 é iniciada uma nova fase na educação brasileira, tendo como base a Refor-

\footnotetext{
${ }^{40} \mathrm{~A}$ universidade oferecia os cursos de Direito, Medicina, Odontologia, Farmácia e Comércio, mas devido à legislação restritiva, após alguns anos, restaram apenas os cursos de Medicina, Engenharia e Direito, em faculdades isoladas, posteriormente reagrupadas em 1950 para a formação da Universidade Federal do Paraná. (id.ibid)

${ }^{41}$ Por conta da Reforma Rivadávia, em 1911 foi criada com recursos privados de um sócio-capitalista, a Universidade de São Paulo, oferecendo cursos de Medicina, Odontologia, Farmácia, Comércio, Direito e Belas Artes. A esperança do investidor era recuperar 0 investimento com as taxas cobradas dos alunos, mas a criação pelo Governo do Estado da Faculdade de Medicina, provocou o desinteresse dos estudantes com relação à universidade privada, que encerrou suas atividades em 1917. Cf. Cunha (2003).

${ }^{42} \mathrm{~A}$ Universidade do Brasil, atualmente denominada de Universidade Federal do Rio de Janeiro (UFRJ), foi criada no dia 7 de setembro de 1920 por meio do Decreto $n^{\circ}$ 14.343/20 do então presidente Epitácio Pessoa, como parte das comemorações do aniversário da Proclamação da Independência do Brasil. A Universidade do Brasil foi formada pela reunião das unidades de ensino superior, já existentes no Rio de Janeiro naquela ocasião: a Faculdade de Medicina (antiga Academia de Medicina e Cirurgia, criada em 1808 por D. João VI); a Escola Politécnica (continuação da Escola Central e da Escola de Engenharia), e a Faculdade de Direito, todas com vida autônoma. A essas unidades iniciais, progressivamente foram-se somando outras, tais como a Escola Nacional de Belas Artes, a Faculdade Nacional de Filosofia e outros cursos que sucederam os iniciais.
} 
ma de Rocha Vaz (consubstanciada pelo Decreto nํ. 16.782-A, de 13/1/1925), que se constitui em uma consolidação das leis e posturas vigentes até então, incluindo as primeiras tentativas de difusão do ensino, a partir de amplo debate parlamentar. Restabeleceu o ensino secundário seriado, com profundas repercussões no ensino superior, extinguindo ainda os exames parcelados no secundário. Curiosamente, vigorou apenas pelo período de 1925 a 1930, época de gestação da Revolução de 1930, que iria novamente reformular o panorama da educação no Brasil, afetando, desta vez, a formação dos professores.

No decorrer deste período, é também regulada a criação de universidades nos Estados, a partir do Decreto nํ. 5.616, de 28/12/1928, possibilitando a reunião das faculdades de Engenharia, Direito, Medicina, Odontologia e Farmácia, já existentes em Belo Horizonte, para a criação da Universidade Estadual de Minas Gerais ${ }^{43}$.

Durante os 40 anos da República Velha (1889 a 1930), foram criadas mais 72 instituições de ensino superior no país, totalizando agora 86 escolas superiores sob o comando da Educação, que até então, estivera entregue a um simples departamento do Ministério da Justiça, nos mesmos moldes do período imperial e, uma das primeiras atitudes da Revolução de 1930, foi a implantação de uma instância específica.

Após a Revolução de 1930, Getúlio Vargas governou na condição de "Chefe do Governo Provisório" (1930-1934), Presidente eleito pelo Congresso Nacional (1934-1937) e como ditador (1937-1945), até ser deposto. Uma das su-

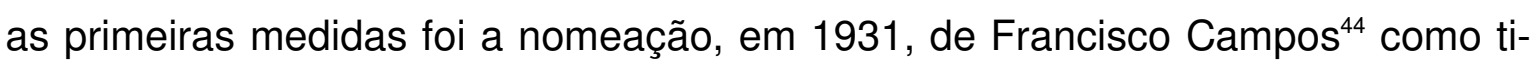
tular do recém criado Ministério da Educação e Saúde Pública. A partir de nova reforma, foi reinstalada a linha cientificista similar à proposta por Benjamim Cons-

\footnotetext{
${ }^{43}$ A primeira instituição de nível superior em Minas Gerais foi a Escola de Farmácia de Ouro Preto, fundada em 1839. Posteriormente, em 1875 é criada a Escola de Minas e em 1892, com a proclamação da República, surge ainda em Ouro Preto a Faculdade de Direito, transferida em 1898 para Belo Horizonte, nova capital do Estado De Minas Gerais. Em 1907, criou-se a Escola Livre de Odontologia e, quatro anos mais tarde, a Faculdade de Medicina e a Escola de Engenharia. Em 1911, é aprovado o curso de Farmácia, que passa a funcionar em anexo à Escola Livre de Odontologia. Embora a criação de uma universidade no Estado fosse parte do projeto político dos Inconfidentes, somente em 1927 é fundada a Universidade de Minas Gerais (UMG), instituição privada, subsidiada pelo Estado, resultante da reunião das cinco faculdades já em funcionamento em Belo Horizonte. A UMG permaneceu na esfera estadual até 1949, quando foi federalizada, sendo atualmente denominada Universidade Federal de Minas Gerais-UFMG.

${ }^{44}$ Francisco Luís da Silva Campos nasceu em Dores do Indaiá (MG), em 1891. Advogado e jurista formado pela Faculdade Livre de Direito de Belo Horizonte, em 1914, fez sua carreira política elegendo-se deputado estadual e Federal em Minas Gerais, quando já defendia as posições antiliberais que o projetariam anos mais tarde e manifestou-se firmemente contra a atuação da jovem oficialidade militar, os "tenentes", que combatiam o governo federal pelas armas. Assumiu a Secretaria de Interior de Minas Gerais em 1926 e com base nos postulados defendidos da Escola Nova, realizou uma profunda reforma educacional no estado. Com a posse de Vargas, assumiu a direção do recém-criado Ministério da Educação e Saúde, graças ao prestígio granjeado na atuação em assuntos educacionais de Minas, quando promoveu a reforma do ensino secundário e universitário no país. Acreditava que a educação seria um processo destinado a criar, conservar ou recuperar certos valores perdidos: a Religião, a família e a Pátria. Sempre ligado aos movimentos direitistas, teve grande atuação política até falecer em 1968.
} 
tant estabelecendo, definitivamente, o sistema de ensino seriado, extinguindo os cursos preparatórios, parcelados e bancas examinadoras, criando um corpo de vigilância escolar que perdurou até 1962.

Surge o Estatuto das Universidades Brasileiras, a partir da promulgação do Decreto no. 19.851, de 11/4/1931, determinando que o ensino superior fosse realizado de preferência em universidades, podendo ser ministrado em estabelecimentos isolados.

Entre outras profundas modificações advindas desta legislação, o ensino médio foi expandido para sete anos, sendo cinco fundamentais e dois complementares, tendo sido também autorizada a implantação das Faculdades de Filosofia, Ciências e Letras, e a instalação de Delegacias Regionais. Cunha (2003, p.137) afirma que "nos primeiros cinco anos da era Vargas, desenvolveram-se no Brasil duas políticas educacionais, uma autoritária, pelo Governo Federal, e outra liberal, pelo governo do Estado de São Paulo e pela Prefeitura do Distrito Federal".

No bojo desta liberalização do ensino e após serem minoradas as retaliações realizadas pelo Governo Federal contra o Estado de São Paulo em decorrência da Revolução Constitucionalista de 1932, foi criada a Universidade Estadual de São Paulo (USP), a partir do embrião inicial representado pela Escola Livre de Sociologia e Política, surgida em 27 de maio de 1933. Por um decreto do Governador do Estado de São Paulo, Armando Salles de Oliveira, em 25 de Janeiro de 1934, foi criada a Universidade Estadual de São Paulo, seguindo o modelo francês de universidade ${ }^{45}$. A USP nasce, então, englobando a Faculdade de Direito, a Escola Politécnica, Escola Superior de Agronomia, Faculdade de Medicina e Escola de Veterinária, às quais foi agregada a Faculdade de Educação, resultante da elevação, ao nível superior existente, o Instituto de Educação. Paralelamente, foram criados e incorporados à Universidade a Faculdade de Filosófica, Ciências e Letras, o Instituto de Ciências Econômicas e Comerciais e a Escola de Belas Artes, além de outros institutos de pesquisa ligados ao governo estadual, entre eles o Instituto Biológico, Instituto de Higiene, Instituto Butantã, Instituto Agronômico de Campinas, Instituto Agronômico e Geofísico, Instituto de Radium,

\footnotetext{
${ }^{45} \mathrm{O}$ corpo docente inicial da USP era composto por 13 professores europeus de alta especialização, sendo 6 franceses, 4 italianos e 3 alemães, e no período até 1942, trabalharam 45 professores e técnicos estrangeiros nos diversos cursos e institutos da USP, número este que se reduziu para 22 em 1942, dos quais 6 ainda eram do corpo docente original. Cf. Cunha (2003).
} 
Instituto de Pesquisas Tecnológicas, além do Museu de Arqueologia, História e Etnografia.

Como diferencial em relação às demais universidades, a USP se notabilizou desde sua criação pelo esforço voltado para a educação e para a formação de professores, de tal forma que a Faculdade de Educação foi concebida como um centro para formação de professores do ensino secundário. A Faculdade de Filosofia, Ciências e Letras, que conforme Cunha (2003, p.168), nas palavras de Fernando de Azevedo, um de seus idealizadores, seria o "coração da universidade, onde se desenvolveriam os estudos da cultura livre e desinteressada", funcionaria como um curso básico e preparatório para todos os cursos, representando uma barreira para as tendências desagregadoras já existentes e impostas pela crescente especialização do saber.

Diferentemente das demais universidades criadas nesta época, a Universidade do Rio Grande do Sul resultou da transformação de uma única faculdade, a Escola de Engenharia de Porto Alegre, que foi criada originalmente em 1896 pelos esforços e doações realizadas por uma baronesa local, que importara 50 professores estrangeiros, principalmente de origem alemã, estabelecendo como referência uma Technishe Hosschule dos padrões humboldtianos, em contraposição ao paradigma francês que predominava no país ${ }^{46}$.

Em 1937 ocorre a reestruturação da Universidade do Rio de Janeiro, que se transforma em Universidade do Brasil, e a criação da Universidade Rural do Brasil. Em 1945, a Universidade do Brasil ganha autonomia administrativa, financeira, didática e disciplinar de acordo com os termos do Decreto-Lei $n ² .8 .393$, de 17/12/1945, promulgado nos tempos do governo de transição de José Linhares e do General Dutra.

A forte expansão quantitativa do ensino nacional nesta época verificou-se, principalmente, no ensino médio, mas por intermédio da Reforma Capanema, proposta pelo Ministro Gustavo Capanema em 1942, a educação secundária passou da extrema aristocratização do ensino para sua completa socialização, atribuindo, ao ensino secundário, a sua finalidade principal, "que é a formação da personalidade do adolescente, adaptando o ser humano às exigências da sociedade, verdadeira finalidade de toda a espécie de educação" (TOBIAS, 1986, p.285), tra-

\footnotetext{
${ }^{46}$ Em 1928, a Escola de Engenharia de Porto Alegre tinha o total de 1.200 alunos, oferecendo curso de Engenharia, Agronomia, Veterinária e Química, além de cursos técnicos para formação de operários especializados para agricultura. Posteriormente, em 1932, transformou-se na Universidade Técnica do Rio Grande do Sul, e finalmente em 1934 foi transformada na Universidade do Rio Grande do Sul.
} 
zendo também influências significativas para o ensino superior, mantido sob a legislação e diretrizes fixadas por Francisco Campos.

No período do governo Vargas, entre 1930 e 1945, foram criadas mais 95 instituições de ensino superior, totalizando 181 em 1945, observando-se que destas, apenas 5 eram universidades, sendo as demais, faculdades isoladas. Este é um dos grandes diferenciais negativos do ensino superior no Brasil com relação ao da Europa e demais países evoluídos, pois aqui, as universidades que se formaram a partir de então resultaram da unificação de faculdades isoladas, ao contrário do ocorrido naqueles países, onde o ensino superior nasceu das universidades. Conforme Tobias (1986, p.286)

\footnotetext{
Deste modo, fixou-se, com o nascimento, a personalidade do ensino superior brasileiro, nascendo daí, como conseqüência, de um lado, o "cursinho" e o "vestibular" e, de outro lado, o curso médio, despersonalizado e reduzido a simples e servil apêndice deste ensino superior, prematura e exageradamente profissionalizante e desumano.
}

Com a renúncia de Vargas em 29/10/1945, finda seu período ditatorial, permanecendo como Presidente provisório o então Presidente do Supremo Tribunal Federal, José Linhares até o término das eleições de 2 de Dezembro do mesmo ano, quando toma posse o General Dutra. Em Setembro de 1946 é promulgada uma nova Constituição Federal, resultante da colagem de partes autoritárias com partes liberais permanecendo a mesma organização educacional, da qual, conforme Cunha (1989) só foram revogados os aspectos mais visivelmente autoritários da legislação, como a educação moral e cívica e a instrução pré-militar nas escolas. No tocante à educação, esta nova constituição permitiu que os Estados, atendendo aos preceitos da federação, implantassem um sistema federal de ensino de caráter supletivo, destinado a atuar nos limites das deficiências locais. Considerando o período entre 1945 e 1960, foram criadas mais 223 instituições de ensino superior no país, totalizando 404 instituições em 1960.

Em 1961 é promulgada a Lei no 4.024 , de 20/12/1961, denominada Lei de Diretrizes e Bases da Educação Nacional, criando o Conselho Federal de Educação. Este período turbulento, em termos políticos, termina por resultar no golpe militar de 1964, a partir do qual ocorrem inúmeras e profundas modificações no sistema de ensino nacional, atrelado ao novo ideário deste movimento, tendo como pressuposto a "segurança nacional".

Com o advento da Revolução Militar de 31 de Março de 1964, a educação brasileira passa a receber forte influência dos EUA, com absorção das teorias e 
práticas educativas lá desenvolvidas e preconizadas como sendo as de maior eficiência com relação à nova racionalidade pedagógica. Nesta época, vários acordos de cooperação foram firmados entre o Ministério da Educação e Cultura (MEC) e a Agência Norte-americana para o Desenvolvimento Internacional (USAID). Voltados para o fornecimento de assessoria técnica e financiamento, visavam viabilizar um processo de modernização da educação, sanando as grandes deficiências constatadas com relação ao treinamento e capacitação das autoridades estaduais de educação.

Assim, em 1965 é expedida a Lei №. 4.881-A, de 6/12/1965, estabelecendo o Estatuto do Magistério Superior, e em 1966 ocorre a reestruturação das Universidades Federais, por intermédio do Decreto-Lei №. 53, de 18/11/1966, complementado pelo Decreto-Lei oㅡ 252 de 28/2/1967, que implantou a Reforma Universitária.

Com a promulgação da nova Constituição Federal de 24/ de Janeiro de 1967 , voltada para a legitimação do golpe militar de 1964, foram criadas as condições para a reformulação do aparelho de ensino nacional, com base na nova política nacional, e assim, em 1968 é baixado o Decreto №. 63.341, de 1/10/1968, que estabelece critérios para a expansão do ensino superior e dá outras providências. Também em 1968, a Lei no. 5.540 de 28/11/1968, conhecido como Estatuto do Magistério Superior Federal, fixou normas de organização e funcionamento do ensino superior, determinando "que a universidade fosse a forma de organização por excelência do ensino superior, restando à instituição isolada o status de excepcional e transitória" (CUNHA, 2003, p.168). Mesmo assim, esta legislação representou certo avanço no sentido de colaborar para a formação de professores-pesquisadores, na medida em que tornava o ensino indissociado da pesquisa, surgindo os regimes de dedicação exclusiva e de tempo integral para o ensino superior.

Os anos que se seguiram foram de grande repressão política e ideológica do Estado contra professores e estudantes, destacando-se o Ato Institucional no5/68 e o Decreto ํㅜ 477/69, que ameaçava, com perda de emprego futuro, os professores, e com a expulsão sumária os estudantes que fossem acusados de práticas consideradas subversivas ao regime vigente.

Durante todo este período, os professores das universidades federais eram contratados em situações diversas, iniciando a carreira como assistente, alçando posteriormente os graus de adjunto e catedrático, nos mesmos sistemas 
preconizados nas universidades européias. O ensino em nível de pós-graduação passou a ser incentivado, motivando grande intercâmbio entre instituições nacionais com norte-americanas e francesas, entre outras, possibilitando grande expansão de novos pesquisadores, que passaram a ser aproveitados como professores, possibilitando uma qualificação significativa do ensino superior.

Embora desde 1910 até 1965 tenha sido obrigatório que o acesso ao magistério superior em instituições públicas federais, fosse feito por meio de concurso de livre docência, nos moldes do sistema alemão, a partir de 1970, este processo foi substituído pelo nível de doutorado como condição de professor adjunto, ficando a cátedra reservada para os livre-docentes. Posteriormente, foram introduzidos concursos públicos para a ocupação dos cargos, realizados entre os professores adjuntos e doutores, situação que possibilitou uma maior flexibilização da carreira docente.

Conforme Saviani (2004, p.42), o modelo de educação proposto pelo regime militar procurava atender a duas demandas contraditórias: por um lado, os jovens ingressantes e professores universitários, estes exigindo maior autonomia universitária, o fim do sistema de cátedras bem como o aumento das verbas para pesquisa e expansão das universidades e, por outro lado, os investidores ávidos do atrelamento do ensino superior às normas do mercado visando a implantação de um sistema voltado para o atendimento dos postulados do capitalismo internacional.

Por intermédio de várias leis, o governo atendeu, parcialmente, estas demandas no tocante ao aumento da oferta de vagas, possibilitando a criação indiscriminada de faculdades isoladas e privadas, invertendo os postulados da universidade clássica. A partir desta situação e como resultado da ideologia dominante, houve impacto negativo e significativo na profissão docente, pois, conforme Perrenoud (2002, p.53)

Não é possível formar professores sem fazer escolhas ideológicas, pois conforme o modelo de sociedade e de ser humano que defendemos, não atribuiremos as mesmas finalidades à escola e, portanto, não definiremos da mesma maneira o papel dos professores. As finalidades do sistema educacional e as competências dos professores não podem ser dissociadas tão facilmente.

Com o final do regime autoritário em 1982, a universidade brasileira foi protagonista e beneficiária do processo de redemocratização do país, principalmente em decorrência da nova Constituição Brasileira de 1988, e da nova Lei no 9.394 de 20/12/1996, também conhecida como "Lei de Diretrizes e Bases" (LDB), 
aprovada em 1996, cujos reflexos principais foram o forte incremento de cursos superiores e de instituições universitárias privadas. A liberalização dos exames de ingresso possibilitou novamente a grande expansão do número de estudantes matriculados, a partir da crescente privatização do ensino superior. Cunha (2003) (30) Por outro lado, embora a criação das universidades permaneça nos moldes anteriores, ou seja, a partir de instituições existentes (as faculdades isoladas reagrupadas), a nova LDB introduziu também um processo de avaliação institucional por intermédio do recredenciamento periódico das instituições de ensino superior, realizado por equipes de professores-visitadores designados pelo Ministério, com as funções de exercer avaliação externa das condições de ensino visando a comprovação da sua qualidade.

Em termos qualitativos, as novas modificações introduzidas pela LDB acentuam-se na esfera dos currículos com a supressão dos currículos mínimos e a introdução de diretrizes curriculares nacionais que preconizam conteúdos gerais, possibilitando que cada instituição de ensino superior adapte seu currículo às demandas regionais, características de seus alunos e do mercado de trabalho local, bem como estabelecendo certa flexibilização na redução do tempo de duração dos cursos. Também nesta direção, foram tornados obrigatórios os trabalhos de conclusão para todos os cursos e o reconhecimento de conhecimentos, habilidades e competências adquiridos fora deles, voltados a desenvolver a autonomia profissional e intelectual dos egressos.

Neste sentido, a Resolução CNE/CES n03/2001 (diretrizes curriculares nacionais para os cursos de enfermagem) preconiza claramente que sejam desenvolvidos, no estudante, a competência do processo intelectual e profissional autônomo e duradouro, permitindo a continuidade do processo de formação acadêmica e/ou profissional, fazendo com que os professores devam também desenvolvêlas, para fazer frente às novas exigências do processo de ensino-aprendizagem na área, objeto da presente pesquisa. 



\section{A trajetória da Educação na Enfermagem}

A Enfermagem, como em outras áreas profissionais e enquanto prática social, vem sofrendo ao longo dos tempos, transformações influenciadas pelas condições sócio-políticas, econômicas e culturais das sociedades, buscando firmar seu espaço no mundo que na atualidade é globalizado, alicerçado no saber científico, sem perder de vista, entretanto, sua essência voltada para o cuidado humano. Segundo Silva (1986), a palavra enfermagem designa o agente que cuida de enfermos, daqueles que não estão firmes, como crianças, velhos e doentes.

Acredita-se que a necessidade de cuidado humano é intrínseca ao ser humano e dessa forma, a origem do cuidado está marcada pela presença do homem (Homo sapiens) no planeta, tendo como primeira forma de manifestação, a proteção materna na nutrição dos filhos e no cuidado aos idosos e doentes.

Durante muito tempo, segundo Oguisso (2005), os cuidados não integravam um ofício ou uma profissão competindo, esses cuidados, a qualquer indivíduo que se dispusesse a ajudar o outro no atendimento de suas necessidades e assim garantir a continuidade da vida no grupo. As manifestações de doenças na era primitiva, preservadas até hoje em algumas culturas, eram atribuídas à influências do mal, personificadas por demônios, com base em crenças e valores relacionados com a existência de um mundo sobrenatural.

Aqueles que possuíam conhecimentos sobre a possibilidade de cura personificavam os pajés, curandeiros, xamãs, feiticeiros e sacerdotes. Por deterem tais conhecimentos, exerciam poder junto aos grupos a que pertenciam e, ao se apoderarem deste poder, fortaleciam o personagem que representavam, e segundo Oguisso (op.cit., p.7), 
Com isso, formou-se uma verdadeira casta de sacerdotes que se apoderavam das funções místicas/religiosas, interpretando e decidindo o que era bom ou mau, e se tornavam guardiões das tradições para supostamente manter a vida do grupo. Sacerdotes executavam ações inerentes ao tratamento e à recuperação dos enfermos, exercendo as funções que seriam próprias de médicos, farmacêuticos e enfermeiros.

Posteriormente, ainda segundo essa autora, o papel de mediador entre o bem e o mau e o de identificador de sinais e sintomas de uma doença apresentada por um indivíduo, deu origem à figura do médico.

Historicamente, podem ser detectadas diferenças entre a enfermagem primitiva e a enfermagem profissional. A enfermagem primitiva remonta à préhistória no sentido dos cuidados dispensados aos doentes, à família ou a indivíduos de um mesmo grupo. Assim, o que se tem de conhecimento sobre a prática da enfermagem, na antiguidade, na verdade, são as atividades direcionadas aos cuidados das crianças e à maternidade.

O rompimento dos aspectos que relacionavam doenças ao misticismo, à religiosidade, ao sobrenatural e à própria filosofia, ocorre com Hipócrates (460 a.C-335 a.C.), principiando a medicina científica e tornando-se conhecido como o pai da Medicina. No entanto, afirma Oguisso (2005, p.55) que "por causa de sua maneira de cuidar dos doentes e de ensinar discípulos a delegar uma parte do tratamento a outras pessoas preparadas, para que acompanhassem o doente na ausência deles", Hipócrates é também considerado por alguns autores, o pai da Enfermagem profissional.

Segundo a mesma autora, textos atribuídos a Hipócrates demonstram que naquela época, a enfermagem era praticada por homens e sob a supervisão de homens. Era recomendado que as decisões fossem tomadas por discípulos, supostos enfermeiros, que eram responsáveis pela observação do doente e pela assistência. Entretanto, parte dessas atividades poderia ser delegada a outras pessoas se estas possuíssem conhecimento e habilidades. Há indicações em textos, de que o enfermeiro deveria relatar as observações feitas, por ele, durante a ausência do médico.

No período denominado Clássico da história antiga, por volta do século IV a.C., nas civilizações grega e romana e especialmente na Grécia, a ênfase voltada para o culto à beleza, à saúde e à moral e à cultura física (especialmente na cidade de Esparta), concorreram para a evolução da medicina e dos cuidados aos doentes. 
Como visto no capítulo II, Roma tornou-se conhecida como um grande império guerreiro na conquista de muitos povos e, além das terras conquistadas, os povos eram submetidos à dominação dos Romanos, incluindo a língua falada, os costumes e as crenças. Quando se deparavam com povos cuja cultura superava a Romana, assimilavam-na num processo de aculturação, como o ocorrido com a Grécia na questão dos conhecimentos filosóficos e da educação, bem como da medicina existente na época.

Entretanto, cita Paixão (1951), Roma sobrepujou a cultura grega no que dizia respeito às questões de saneamento, que eram preocupações de seus governantes. Possuía ruas limpas, casas arejadas, água pura em abundância, banhos públicos, redes de esgoto, drenagem de água de regiões pantanosas distantes e cuidava do sepultamento de seus mortos. Além disso, existiam hospitais para o restabelecimento dos soldados, uma vez que o exército guerreiro era muito valorizado para o cumprimento de seus propósitos.

A passagem de Jesus Cristo no planeta, segundo Oguisso (2005, p.35), marca um período importante da história e de acontecimentos voltados para o cuidado humano, pois

\begin{abstract}
Apesar das perseguições que sofria a religião cristã, houve considerável crescimento do fervor religioso. Com isso, muitos cristãos passaram a dedicar sua vida à prática da caridade, o que deu origem a inúmeras congregações religiosas, que atraíam homens e mulheres vocacionados para cuidar de pobres e doentes em busca de salvação eterna. Essas congregações construíram diversos hospitais para prestar assistência, sempre nas vizinhanças de igrejas e mosteiros.
\end{abstract}

Ainda para a mesma autora, no primeiro século do cristianismo surgem as verdadeiras "damas da lâmpada" que eram visitadoras domiciliares, consideradas as precursoras da enfermagem de saúde pública.

A instituição da ordem das diaconisas foi o primeiro grupo organizado para visitar doentes e a eles prestar assistência. Entre as inúmeras atividades para atender às necessidades dos doentes e dos desamparados, estavam os cuidados em banhar os doentes com febre, limpar feridas, fazer curativos, dar água e comida, oferecer remédios à base de ervas e raízes e manter as condições de higiene e ventilação do ambiente. A devoção e o amor dedicados a esses cuidados, na realidade, era o que ficava evidente.

Por muitos anos, instituições como as das diaconisas se mantiveram neste propósito e, posteriormente, outras instituições se formaram, seguindo o mes- 
mo caminho, ressaltando-se que eram constituídas de mulheres tidas como da alta classe social. (id.ibid)

O período histórico conhecido como Idade Média, atingindo do século $\mathrm{V}$ ao XVII, teve início com a queda do Império Romano, no ano de 476. Os primeiros séculos deste período foram marcados pelo sistema feudal e o modo de produção que vinculava os camponeses ao seu senhorio, em um ambiente hostil, onde eram freqüentes as disputas entre os senhores feudais no domínio de terras. Nesta época, as atividades de cuidar, segundo Oguisso (2005, p.13)

\begin{abstract}
consistiam em delegar às mulheres a tarefa de se dedicar fundamentalmente à compensação das perdas demográficas causadas pelas guerras continuadas e pelas epidemias. A reprodução, que garantia a perpetuação e a sobrevivência do grupo, exigia, dada a alta mortalidade infantil, o maior cuidado com o momento pontual de alto risco: o parto, assistido em geral por viúvas e mulheres mais idosas com experiência.
\end{abstract}

Outras transformações neste período, desencadeadas pelos movimentos da reforma protestante e contra-reforma católica ocorreram sem, contudo, modificar o modo da Enfermagem, uma vez que ambas as partes consideravam que as atividades de promoção de cuidados aos enfermos eram um exercício do espírito cristão e da prática da caridade e era praticada por mulheres de classe social alta e da burguesia.

Em toda a Europa, durante a Idade Média, a medicina (e a enfermagem vem associada ao seu desenvolvimento), foi praticada sob dois enfoques: um seguindo as tradições do Império Romano, conhecida como medicina laica, praticada por homens que, por pertencerem a uma ordem militar, seguiam as regras da disciplina, a hierarquia e a obediência, e outro, a medicina que existiu junto aos mosteiros, conhecida como medicina eclesiástica.

O cristianismo influenciou sobremaneira a prática dos cuidados ao valorizar a atenção voltada para os pobres, desamparados e doentes. Com isto, reis e rainhas, pessoas da alta sociedade, abriam mão de seus bens para se dedicar a caridade.

O movimento das Cruzadas ${ }^{47}$ exerceu forte influência na enfermagem, que era praticada por homens (monges) os quais, além das funções militares, também exerciam funções religiosas e de assistência de enfermagem. Esta influência

\footnotetext{
${ }^{47}$ As Cruzadas consistiam em expedições militares organizadas pelos cristãos no final do século XI, para libertar e recuperar a Terra Santa, dominada pelos muçulmanos desde o século VII.
} 
constituiu um marco importante na formação dos primeiros enfermeiros, conforme aponta Oguisso (2005, p.22), para quem

não há dúvida de que a enfermagem sofreu forte influência das Cruzadas, uma vez que a rígida hierarquia e a disciplina existentes na vida militar e mesmo na clerical e religiosa foram em muito assimiladas pelos pioneiros para moldar a formação dos primeiros enfermeiros.

Inúmeras ordens religiosas foram se constituindo a partir de então, estando a elas associadas as práticas do cuidado, sendo sempre na visão cristã de atendimento aos desamparados. Observa-se que neste período, devido às constantes guerras, aos movimentos sociais e religiosos, a Europa foi assolada por epidemias e miséria.

Uma outra reforma religiosa ocorrida em 1534 na Inglaterra, levou a uma crise conhecida como o período negro da enfermagem, decorrendo do rompimento de Henrique VIII (1491-1547) com a Igreja Católica, ao ser negado seu pedido de separação de matrimônio. Descontente, além de criar a separação total desta com a Igreja da Inglaterra por ele fundada naquela data, o monarca expulsou todos os religiosos que prestavam assistência aos doentes, sem ter quem os substituíssem, gerando um grande caos. A substituição foi feita, então, por meio de recrutamento direto junto à população, que resultou na formação de um novo contingente formado, em grande parte, por mulheres analfabetas e pouco escrupulosas.

O período chamado Renascença surge renovando as esperanças e o modo de vida e de pensamento do povo existente na época. É o movimento influenciado pelo humanismo, resgatando o patrimônio cultural das artes, da filosofia e do conhecimento pouco praticados durante a Idade Média.

A grande contribuição da Renascença foi a organização das sociedades que se transformaram, posteriormente, em nações, permeadas pela expansão de conhecimentos e de novas idéias, principalmente com a invenção da imprensa, favorecendo a informação. A Renascença possibilitou, ainda, uma explosão de pensamentos criativos nas Universidades, fortalecendo esses centros de aprendizagem. Neste período, segundo Oguisso (op.cit, p.60), "a educação médica encontrou seu rumo no ambiente universitário, mas a enfermagem não teve a mesma sorte", pois segundo Leopardi (1999), "já se consolidara a figura dos cirurgiões e médicos, livres tratadores que iam de cidade em cidade oferecer seus préstimos". 
No final do século XVIII, na França, a medicina moderna teve seu início marcado pela organização da clínica, associado às grandes descobertas da física e da química. Neste período, segundo Foucault (1998), os hospitais acolhiam os indivíduos excluídos da ordem pública, ou seja, os pobres e os desamparados, favorecendo a exploração e o tratamento do corpo humano no que diz respeito à observação e à experimentação de novos conhecimentos. Diante deste cenário, o cuidado tornou-se sinônimo de tratar a doença e, o paciente, razão desse cuidado, ter permanecido excluído e isolado das questões sociais. O aparecimento de especialistas com a atenção voltada, unicamente, para a investigação e experimentação de novos conhecimentos, não dava conta de tratar os doentes. Para atender à demanda dessas atividades, passaram a contar com a ajuda de outras pessoas, surgindo então a enfermagem profissional.

Assim a Enfermagem atravessa a história, identificada pelos cuidados básicos necessários aos doentes, praticada por homens e mulheres influenciados, inicialmente, pelo instinto humano de sobrevivência e de manutenção da espécie e, posteriormente, pelo militarismo e pelas questões religiosas. Para Oguisso (2005), essa trajetória influenciou de forma definitiva a prática da enfermagem demonstrando que esta, como profissão, está vinculada ao progresso e à prática da medicina, à evolução dos hospitais e, de forma indireta, ao surgimento da Revolução Industrial e da emancipação feminina.

A implantação dos hospitais foi iniciada com propósitos mais complexos do que apenas cuidar e curar, entendendo-se que em atendimento ao novo paradigma da produção, passou a assumir funções de controle, confinamento e exclusão social, substituindo o cuidado familiar até então proporcionado, por pessoas despreparadas e sem vínculos afetivos com os internados. Com isto, o acúmulo de novas funções e maiores contingentes de pacientes fez com que as tarefas ultrapassassem os limites de ação dos médicos, surgindo então a enfermagem como nova profissão institucionalizada, mas com características diferenciadas com relação à medicina.

Os períodos seguintes foram marcados por sucessivos esforços para 0 ensino da enfermagem nos continentes europeu e americano, cabendo, aos médicos, os primeiros ensaios para ensinar a cuidar de doentes, a partir da necessidade de desenvolver pessoas que pudessem auxiliar no trabalho médico. 
Segundo Oguisso (2005, p.60)

A primeira iniciativa de que se têm notícias parece ter ocorrido em Nova York, em 1798, quando o cirurgião Valentine Seaman, do Hospital Bellevue, começou a dar cursos regulares com aulas teóricas e demonstrações práticas de anatomia, fisiologia, obstetrícia e pediatria para mulheres, para que elas pudessem trabalhar como "enfermeiras".

Ao contrário do que ocorreu na enfermagem primitiva, que era praticada por leigos em geral sem preparo, na enfermagem profissional o enfermeiro passou a ter uma formação específica, resultado de um processo de ensinoaprendizagem peculiar às suas atividades, voltado para a construção de competências nessa área do saber e para tanto, dependendo diretamente, dos docentes que $o$ auxiliassem neste processo. Nesse contexto, a enfermagem profissional caracteriza-se como sendo aquela na qual, como em outras profissões, seus agentes passam a ser autorizados a praticá-la a partir do domínio de conhecimentos científicos, bem como de técnicas e preparo adequados, passando a receber remuneração e principalmente, se organizando para o exercício dos cuidados dispensados ao doente.

O registro mais antigo do ensino de Enfermagem que se tem notícia no continente europeu encontra-se na Espanha onde foi publicado, em 1833, o livro intitulado "A arte de enfermagem para a assistência teórico-prática dos pobres enfermos".

Em 1812, nas Ilhas Britânicas, um grupo protestante, as Irmãs de Misericórdia, organizou esforços para estabelecer um novo sistema de Enfermagem, encaminhando, três dessas Irmãs a Paris, para aprenderem a praticar a enfermagem. Entretanto apesar do propósito, não conseguiram fundar uma escola, mas um hospital para cuidar de doentes.

O pastor luterano Theodor Fliedner (1800-1864) fundou, em Kaiserswerth, na Alemanha, o Instituto das Diaconisas, escola freqüentada por Florence Nightingale para aprender a praticar a enfermagem.

Em 1848, foi criada em Londres, a Casa de São João, com o objetivo de atrair jovens mulheres para a enfermagem e principalmente, estabelecer um treinamento sistemático de enfermeiras para trabalhar em hospitais. Em 1856, o Hospital King's College assumiu todo o serviço de enfermagem, criando em 1885 a sua própria escola. Os dois primeiros anos do preparo consistiam em um período probatório e, ao seu término as jovens eram qualificadas como enfermeiras, também conhecidas como "nurses". 
Nesta nova proposta, as "nurses" poderiam permanecer por até cinco anos, com direito a alojamento, alimentação e salário. Após este período, passavam à categoria de "sister". Ainda hoje persiste este modelo hierarquizado na Inglaterra, onde as "nurses" são enfermeiras assistências e de unidades e as enfermeiras "sisters", as supervisoras.

Diferentemente da Inglaterra, em Portugal e França, a enfermagem seguiu caminhos distintos. Na França, os pacientes e serviçais dos hospitais eram comandados por religiosas que exerciam essencialmente, a função de supervisão, sendo que seus direitos e obrigações eram estabelecidos pelas congregações e comissões administrativas dos hospitais.

Neste período, os hospitais ainda eram locais de refúgio e amparo aos pobres e doentes que as religiosas acolhiam e suas atividades limitavam-se à manutenção das tradições religiosas, negando-se a assumir novas tarefas que passaram a ser assumidas pela medicina, permanecendo a presença dessas religiosas apenas para o cuidado dos doentes, sob o foco religioso.

As descobertas de Pasteur sobre a existência de microorganismos, deram início a grandes transformações relativas aos costumes e assepsia da época, pois com a possibilidade de contágio, surgiu a necessidade de novas táticas de defesa, às quais as religiosas se recusavam a aceitar. Cabe ressaltar que estas religiosas detinham o poder de comando sobre todo o pessoal auxiliar e serviçal dos hospitais existentes.

Com o nascimento da clínica, o hospital passou a ser o centro do saber, do desenvolvimento e da formação do médico e as religiosas, aos poucos, foram sendo afastadas ou abandonando os hospitais. Nessa trajetória, as religiosas começaram a ser substituídas, atendendo a uma necessidade médica, pois estes precisavam auxiliares e o perfil desejado para as pessoas que iriam desenvolver essas atividades, segundo Oguisso (2005, p.62) era:

com as qualidades de devotamento, submissão e rigor na ordem e limpeza, como eram as religiosas, mas sem o caráter confessional de uma determinada religião. Queriam uma espécie de religiosa leiga, que aceitasse a submeter-se a eles. Para isso queriam recrutar jovens de origem modesta a quem iriam ensinar os princípios de higiene, pois Ihes dariam competência na limpeza hospitalar.

Este foi um marco importante na profissão de enfermagem na França conforme afirma a autora: 
Poder-se-ia dizer de um certo modo que a profissão de enfermagem nasceu na França a partir desse ritual de cuidados praticados por essas leigas treinadas por médicos interessados em mudar atitudes, mas que limitavam a instrução às funções que elas deveriam executar, sempre secundando o médico, pois eram meras executoras de ordens, proibidas de tomar qualquer iniciativa.(id.ibid)

$\mathrm{Na}$ França, o ensino de enfermagem também teve inicio com médicos da época, interessados na formação de enfermeiras. Contribuíram com a criação de uma literatura pedagógica na forma de manuais que foram utilizados em diversos países da Europa e também no Brasil, no início do século XX na Escola Profissional de Enfermeiros e Enfermeiras.

Entre esses médicos, Desiré Magliore Bournevulle se destacou pelo incentivo e fundação de diversas escolas leigas de enfermagem, sendo diretor de uma delas durante vários anos.

No final do século XIX em Portugal teve início o ensino de enfermagem surgindo a primeira escola de enfermagem na cidade de Coimbra em 1881, cujo intuito era dar melhor instrução aos enfermeiros e enfermeiras e habilitar as criadas dos estabelecimentos. Vale ressaltar que este curso partiu da iniciativa de um administrador de hospitais e de um professor da Faculdade de Medicina, que já sabiam da existência de escolas semelhantes em Paris, desde 1878.

Em 1887 é criado em Lisboa um curso de enfermeiros no Hospital Real de São José, também por iniciativa de um médico. Este curso foi extinto em 1889 e posteriormente, em 1901 por iniciativa de um administrador, neste mesmo Hospital foi criada a Escola Profissional de Enfermeiros que existe até hoje com o nome de Escola Superior de Enfermagem Artur Ravara.

Nos Estados Unidos da América, o médico Joseph Warrington, preocupado com a qualidade dos cuidados dispensados às mulheres pobres durante o parto, criou um curso regular com aulas e demonstrações práticas e publicou um livro intitulado "Guia das enfermeiras" contratando cerca de 50 enfermeiras entre 1839 e 1850. Nesta época, a enfermagem estava ligada à vida doméstica e ao domínio do lar.

Com o advento da guerra civil americana entre 1860 e 1865, os cuidados foram delegados a mulheres voluntárias, viúvas e leigas, sendo necessário um treinamento para que pudessem desenvolver as atividades relacionadas aos cuidados, sendo estes treinamentos ministrados por médicos e cirurgiões. Entretanto, esses treinamentos não foram suficientes para capacitá-las, frente à demanda de trabalho com os feridos na guerra. 
Assim, foi formado o primeiro corpo de enfermeiras do Exército por uma professora, Dorothea Lynde Dix, sendo que as diretrizes para a organização das atividades haviam sido as mesmas sugeridas por Florence Nightingale uma vez que, também, eram pautadas pelas inúmeras dificuldades vividas, por ela, anteriormente. Segundo Oguisso (2005,p.65),

o papel dessas voluntárias que trabalhavam na guerra sem nenhuma sofisticação seguia a trilha da fama de Florence Nightingale e chamou a atenção da população sobre a necessidade de haver alguma forma organizada de treinamento para enfermeiras.

Nessa época, na cidade de Boston, estado de Massachusetts, foi introduzido o sistema de ensino do Instituto das Diaconisas de Kaiserswerth (oriundo da Alemanha), no Hospital Geral da cidade.

Posteriormente, as escolas de enfermagem existentes nos Estados Unidos da América que seguiam um ensino médico, foram substituídas pelo modelo de ensino moderno de enfermagem ou nightingaleano. A primeira escola norteamericana a adotar esse sistema de ensino de enfermagem foi a Escola de Preparação Profissional, do Hospital Bellevue, de Nova York, em 1873.

A característica desse sistema de ensino era a rigorosa seleção das candidatas, levando em consideração a questão do físico, da moral, o potencial intelectual e a aptidão profissional. O ensino deveria ser teórico e prático e a direção das escolas e dos serviços de enfermagem deveria ser exercida por enfermeiras.

A Escola de Enfermagem fundada por Florence Nightingale, após quatro anos da guerra da Criméia ${ }^{48}$ começou a funcionar em 9 de julho de 1860 e em 1872 ficou instalada no Hospital Saint Thomas em Londres, onde já havia uma escola de medicina. A escola tinha por objetivo preparar enfermeiras, multiplicadoras de conhecimentos e ainda formar enfermeiras distritais para cuidar dos doentes pobres.

O curso contava com um grupo pequeno e bem selecionado de 15 alunas e a seleção era feita pela própria Florence, havendo cerca de mil a duas mil candidatas. O que se buscava na seleção eram as qualidades de caráter moral associadas às habilidades como saber ler e escrever bem e, para as que iriam supervisionar as enfermarias, era exigida também a habilidade para ensinar. Embora

\footnotetext{
${ }^{48} \mathrm{~A}$ guerra da Criméia se estendeu de 1853 a 1856, começando possivelmente após uma discussão entre monges ortodoxos russos e católicos franceses sobre quem teria preferência sobre os locais sagrados em Jerusalém e Nazaré. Envolvendo as forças do Império Turco-Otomano (atual Turquia), Grã Bretanha, França, Sardenha (atual Itália) e da Rússia, desenvolveu-se nos territórios da Moldávia e Valáquia (atual Romênia) e na Península da Criméia, atualmente denominado República Autônoma da Criméia, parte administrativa territorial da Ucrânia.
} 
céticos quanto à real necessidade de se investir na formação de enfermeiras, esses médicos contribuíram com aulas teóricas de anatomia, fisiologia e farmacologia. O curso tinha, inicialmente, a duração de um ano e posteriormente passou para dois no qual foram incluídas as práticas nas enfermarias do hospital.

Mesmo passando um período crítico inicial de dificuldades, Florence conseguiu superá-las após dez anos, formando cerca de quinhentas enfermeiras que seguiram trabalhando dentro e fora do país, organizando e dirigindo os serviços de enfermagem.

Florence Nightingale teve grande importância para a enfermagem, elevando o status social da profissão e é considerada a fundadora da moderna educação de enfermagem. Segundo Oguisso (2005, p.76),

\begin{abstract}
A filosofia de vida de Florence permeava todo o currículo de sua escola. Ela acreditava que a saúde deveria estar presente tanto na alma como no corpo. Seu currículo não tinha um conjunto de metas a ser atingidas, mas procurava estimular o desenvolvimento individual das alunas. Ela acreditava que cada pessoa tinha talentos e habilidades que precisavam ser desabrochados. $O$ treinamento era uma forma de fazer que a aluna usasse seus recursos intelectuais inatos. Florence enfatizava que fazer enfermagem era ajudar a pessoa a viver; para ela a escola deveria ensinar à enfermeira sua função de ajudar o paciente a viver. Portanto, enfermagem era uma arte que requeria treinamento organizado, prático e científico; a enfermeira deveria ser uma pessoa capacitada a servir à medicina, à cirurgia e à higiene e não a servir aos profissionais dessas áreas. Florence entendia que a enfermagem era o corolário necessário desses campos e que, para o bem estar dos pacientes, a enfermeira deveria saber adaptar suas habilidades ao trabalho da equipe. Para tanto, ela deveria obedecer de forma inteligente, sempre usando o discernimento.
\end{abstract}

O sistema de ensino de enfermagem proposto por Florence foi gradativamente se difundindo, até meados do século $\mathrm{XX}$, embora o modelo médico ainda fosse adotado em alguns países.

Na América Latina, a primeira escola de enfermagem foi criada na Argentina em 1886 e em 1890 foi implantado o novo sistema de ensino.

No Brasil, este percurso histórico até 1890, mostra que a enfermagem era baseada no misticismo, nas crenças e na solidariedade humana, como a desenvolvida na Europa. Antes do descobrimento do Brasil, a população indígena, aqui existente, estava organizada conforme sua cultura, atribuindo as atividades relacionadas ao cuidado à figura central dos curandeiros. No período colonial, o cuidado aos doentes ficava ao encargo de religiosos e escravos que auxiliavam no cuidado dos familiares de seus senhores. 
A congregação das Irmãs de Caridade chegou ao Brasil na cidade do Rio de Janeiro, em 1852, com a missão religiosa e de assistência aos enfermos das Santas Casas de Misericórdia que foram criadas no período entre 1543 e 1880.

Com o intuito de eliminar o charlatanismo, em 1850 foi criada a Junta de Higiene Pública com sede na corte (Rio de Janeiro), ficando esta entidade, responsável pelo registro dos diplomas dos médicos, cirurgiões, boticários, dentistas e parteiras, dando início à regulamentação e controle do exercício profissional na área da saúde.

Conforme Moreira (2005), o Decreto no. 791/1890, resultante de um processo político que apontava a necessidade de pessoas treinadas e com características adequadas para cuidar de doentes mentais, veio instituir o ensino formal e o processo de profissionalização da enfermagem no Brasil com a criação oficial da primeira escola de ensino de enfermagem na cidade do Rio de Janeiro no Hospital Nacional dos Alienados. Implantada por enfermeiras francesas nos moldes do serviço de enfermagem do Hospital Salpetrière, possuía o corpo docente composto por médicos de saúde mental e seus alunos, que se julgavam portadores de qualidades morais condizentes. Baptista, Barreira (1999) referem que mais tarde, a reforma dos sistemas de saúde pública da então capital federal modificou esta escola de acordo com os padrões anglo-americanos, objetivando a formação de enfermeiras de saúde pública voltadas para a visitação domiciliar. Segundo as autoras, neste momento o corpo docente passou a ser composto por eminentes médicos brasileiros e enfermeiras norte-americanas, que aqui reproduziam o ensino das melhores escolas de lá, sob a direção de uma enfermeira também norteamericana. $^{49}$

A primeira escola de enfermagem a adotar o sistema nightingaleano foi a do Hospital Samaritano, na cidade de São Paulo, cujo estatuto, datado de 1890, previa a criação de uma escola de enfermagem. Outras instituições de ensino de enfermagem foram surgindo, atendendo a necessidade da época, que era a de se ter pessoas qualificadas e competentes para o exercício profissional.

Seguiu-se, às escolas já mencionadas, a Filial de São Paulo da Cruz Vermelha Brasileira, criada em 1912 e, a criação no Rio de Janeiro, de mais dois cursos sendo um em 1914, a Escola de Enfermeiras Voluntárias e outro em 1916,

\footnotetext{
${ }^{49} \mathrm{~A}$ influência norte-americana nesta época se fez por meio da Missão Parsons, encarregada de auxiliar e chefiar o Departamento Nacional de Saúde Pública e pela Fundação Rockfeller, que concedia bolsas de estudo para as melhores alunas realizarem cursos de especialização nos EUA. O modelo de ensino era extremamente rígido, nos moldes de instrução para-militar, com castigos e punições severas. Cf. Baptista, Barreira (1999)
} 
a Escola de Enfermeiras Práticas. Ambos com o objetivo de melhorar as condições de assistência aos feridos da I Guerra Mundial. Em 1917 foi criado o Curso de Enfermeiras da Policlínica de Botafogo, no Rio de Janeiro.

Conforme visto anteriormente, o sistema educacional no Brasil, nessa época, procurava dar instrução primária a uma parte da população, pois o preparo profissional estava restrito a uma elite, dando, aos homens, a prioridade de estudar e obter nível universitário, o que implicava na baixa escolarização feminina, dificultando o recrutamento das mulheres para os cursos de enfermagem.

A necessidade de combater inúmeras doenças desencadeadas pelas precárias condições de saneamento básico, resultante do descontrolado processo de urbanização, resultou na criação do curso intensivo para Enfermeiras Visitadoras, na cidade do Rio de Janeiro, pelo Departamento Nacional de Saúde Pública, em 1921. Esta mesma escola passou a chamar em 1923, Escola Ana Néri e é atualmente a Escola de Enfermagem da Universidade Federal do Rio de Janeiro.

O crescimento das escolas de Enfermagem, no Brasil, se expande a partir de da década de 1940, quando são abertas mais de 23 escolas sendo que até 1933 existiam apenas duas. Nessa época houve uma renovação nos hospitais aumentando o mercado hospitalar para as enfermeiras, sendo importante salientar que até o final da década de 50 , as escolas de Enfermagem não possuíam "status" de instituição de nível superior por serem consideradas voltadas para uma profissão que detinha o predomínio de atividades técnicas.

A grande reforma do ensino de enfermagem ocorreu em 1949, pela lei no. 775 de 06 de agosto de 1949 que uniformizou o ensino da enfermagem, e do Decreto ํ․ 27.426 de 14 de novembro 1949, que estabeleceu o currículo para a formação do enfermeiro. (Brasil, 1974). Baseado no modelo de escolas americanas de 1937, este modelo era voltado ao mercado de trabalho e, portanto, tendo a área hospitalar como predominante, com as especialidades médicas sendo acompanhadas de conteúdos de Enfermagem, havendo fragmentação da teoria e da prática.

Segundo Saupe (1998), este modelo, seguindo as orientações do "curriculum guide" americano, preconizava o modelo taylorista e conseqüentemente, a divisão do processo de trabalho ${ }^{50}$. Para Lima (1994, p.274) "o que se percebe,

\footnotetext{
${ }^{50}$ A Fundação Rockfeller patrocinou durante a $2^{\text {a }}$ Guerra a implantação de uma escola de enfermagem no nível universitário com objetivo de dar sustentação do projeto do Hospital das Clínicas de São Paulo, agora com corpo docente integralmente brasileiro. Cf. Baptista, Barreira (1999)
} 
portanto, é que essa alteração do currículo não atendia às expectativas educacionais de Enfermagem, ao se levar em consideração expectativas da sociedade quanto ao trabalho do enfermeiro".

A Enfermagem brasileira firma-se, definitivamente, como profissão de nível universitário a partir de 1962, quando passa a ser reconhecida pela evolução de seu ensino, passando a integrar o sistema geral de ensino do país. Isto ocorre como resultado da promulgação da Lei de Diretrizes e Bases da Educação Nacional (LDB) de dezembro de 1961, que torna obrigatório para os alunos de enfermagem a conclusão do curso secundário, que até então não exigido.

A partir de 1962, com o Parecer №. 271/62 do então Conselho Federal de Educação fica estabelecido o Currículo Mínimo dos Cursos de Enfermagem, com a duração de três anos e introduzidas as especializações, como optativas. Este Parecer elimina do currículo do curso geral a disciplina de Enfermagem em Saúde Pública, por considerar que esta disciplina passaria para o nível de especialização e ainda, inclui a Administração em Enfermagem como parte do currículo mínimo.

Com a aprovação deste currículo, começa um movimento das enfermeiras, docentes e da Associação Brasileira de Enfermagem (ABEn) com a intenção de melhorar a qualidade do ensino, não concordando com a duração de três anos de curso, assim como, com a exclusão das disciplinas da área de saúde publica. Posteriormente, com o Parecer no. 163/72 é fixado um novo currículo mínimo pelo Conselho Federal de Educação, com ciclo básico, tronco profissional comum e a possibilidade de opção em três habilitações (Enfermagem em Saúde Pública, Enfermagem Médico-Cirúrgica e Enfermagem Obstétrica).

No entanto, verifica-se que a consolidação do ensino de enfermagem ocorreu com a promulgação da Lei o 5540 de 28/11/1968, relativa à Reforma Universitária, que possibilitou a introdução dos cursos de pós-graduação stricto sensu, com a finalidade de formar professores para a graduação, bem como profissionais para as empresas públicas e privadas, além de incentivar os estudos e as pesquisas voltadas para o desenvolvimento do país. Esta modificação qualitativa repercutiu muito nos cursos de enfermagem, pois, conforme afirmam Baptista, Barreira (1999, p.75),

No que se refere às professoras, as que haviam realizado cursos de pósgraduação nos EUA e Canadá foram credenciadas pelo MEC como docentes de pós-graduação stricto sensu, embora a pesquisa científica ficasse restrita a poucas professoras, de algumas instituições.As demais, ao mesmo tempo em que tentavam se adaptar às novas situações de ensino-aprendizagem que o novo currículo lhes trazia, e mesmo sem te- 
rem passado por um processo ordenado de iniciação científica, tornaram-se estudantes de pós-graduação, pois tiveram de fazer o curso de mestrado e defender suas dissertações, muitas vezes sem liberação integral de sua carga horária docente.

$\mathrm{Na}$ década de 80, tem início um período de grandes mudanças, com a Reforma Sanitária e a implantação do Sistema Único de Saúde (SUS). Segundo Silveira (2004, p.27), "nessa época, a enfermagem é marcada por discussões quanto o objeto, meios e instrumentos do trabalho, aplicação das Teorias de Enfermagem e estudos sobre a força de trabalho nesta área”.

A exigência do mercado de trabalho e do setor de saúde pública é por profissionais capacitados, nesta área, necessitando um repensar docente na formação de enfermeiros.

Em dezembro de 1994, conforme o Parecer nํ. 314/94 do Conselho Federal de Educação, homologado pela Portaria n. 01721 do Ministério da Educação e do Desporto, foi aprovada a proposta da ABEn de um projeto político-pedagógico para a enfermagem, discutindo esta, como prática social voltada para uma proposta curricular com base na pedagogia da problematização.

Após dois anos, com a nova Lei de Diretrizes e Bases da Educação Brasileira (LDB) n. 9.394/96, novos debates e impasses ocorrem na enfermagem, e finalmente em 2001, o Conselho Nacional de Educação e a Câmara de Educação Superior divulgam a Resolução №. 3/2001, a respeito das Diretrizes Curriculares Nacionais (DCN) do curso de graduação em enfermagem, que prevê a formação do enfermeiro generalista, humano, crítico e reflexivo, tendo como base o rigor científico e pautado em competências e habilidades, conteúdos essenciais e indicadores de avaliação.

Nesse resgate histórico, verifica-se que várias transformações vêm ocorrendo, chegando até a legislação vigente, que disciplina o funcionamento dos cursos de graduação em enfermagem no país.

Segundo Saupe (1998), esse processo evolutivo da profissão enfermagem, no Brasil, vem sendo dirigido pelas escolas e pelos modelos de currículo mínimo obrigatório, legalmente determinado.

Esta mesma autora refere que, a evolução do currículo para o preparo de enfermeiros "inicia-se com um enfoque generalista e comunitário e vai se adaptando às políticas de saúde emergentes e ao modelo de privatização dos serviços de saúde" (op.cit.p.37). 
Todo este movimento histórico indica o comprometimento, especialmente de docentes de enfermagem na formação de futuros profissionais.

Para Sacristán, Gómez (1998, p.207),

\begin{abstract}
O professor (a) não trabalha no vazio, mas dentro de organização que regula as práticas: as condições de escolarização, a regulação do currículo realizada fora das aulas e a flexibilidade para desenvolver o trabalho dos docentes. A autonomia profissional possível para os professores (as) de uma escola reside no terreno fronteiriço que gera a dialética entre as pressões externas e a prática que é possível elaborar no marco organizativo de cada escola. Um terreno que será ou não aproveitável em função da formação do professorado e segundo o grau de agremiação entre estes indivíduos.
\end{abstract}

Paralelamente à regulamentação da profissão e ao estabelecimento do currículo que norteia a formação do enfermeiro, estão as questões relacionadas à capacitação pedagógica dos docentes de enfermagem que, conforme aponta Nimtz (2003, p.35), é uma situação inquietante, "pois há um visível crescimento do número de escolas de graduação de enfermagem e pelo fato de os enfermeiros que se tornam professores nem sempre receberem preparo para exercer a atividade educativa".

No Brasil, o ensino de enfermagem, segundo Nietsche (1998, p.149), "esteve na grande maioria das vezes voltado aos interesses da classe dominante e das políticas de governo".

A preocupação com a capacitação dos docentes de enfermagem vem acompanhando a trajetória histórica, quando, enfermeiras brasileiras saem para outros países (Estados Unidos e França), em busca desta capacitação assumindo, posteriormente, cargos de diretoras de escolas de enfermagem que, até então, ficavam sob a direção de enfermeiras americanas e francesas.

Entretanto, o ensino de enfermagem no Brasil também vem sendo influenciado pelas Teorias da Educação, desenvolvidas ao longo da história, ou por seu estudo e conhecimento no processo de ensino/aprendizagem, ou, vem sendo utilizadas, por reprodução, o que ocorre em sua maioria. As correntes, tendências, modelos, estilos e concepções que compõem os estudos das Teorias da Educação vêm influenciando a escola (o ensino geral) e, portanto, a formação do indivíduo nas últimas cinco décadas do século XX.

Conforme Poentes (2004), o desejável e necessário caminho para o aperfeiçoamento da Pedagogia e dos sistemas educacionais na América Latina, como a própria prática escolar que buscava concretizar condições que assegurassem 
aos docentes, a realização e avaliação de seu trabalho, deu origem e possibilitou o desenvolvimento de estudos referentes às Teorias Educacionais.

Em que pese todo o empenho e desenvolvimento desses estudos, sua influência na enfermagem permanece focada nas teorias tradicional e tecnicista e conforme aponta Nietsche (id.ibid), "talvez com outras máscaras".

Já para Gualda, Mereghi e Oliveira (1995, p.298),

\begin{abstract}
Apesar da influência que a educação em enfermagem está sujeita, muitos educadores têm concluído que abordagens tradicionais, embora transmitidas aos alunos por décadas, não são mais aceitas para a realidade atual, que exige de seus profissionais, além de competência técnica, a capacidade criativa, de reflexão, de análise crítica e um aprofundamento constante de seus conhecimentos.
\end{abstract}

Estudos recentes na área de ciências sociais e educação apontam para a necessidade da reflexão e da criticidade na formação do indivíduo, pensando a futura humanidade. Ianni (2002) afirma que o avanço tecnológico da comunicação e do novo mapa do mundo, frente à globalização, exige esta reflexão não só dos docentes e de outros profissionais, mas de todo cidadão.

Diante deste cenário, o profissionalismo deixa de ser um diferencial competitivo e passa a ser uma questão de sobrevivência exigindo que o docente se volte, cada vez mais, para o desenvolvimento de competências, pois como afirma Shinyashiki (1997), "na sociedade da informação, ao mesmo tempo em que a tecnologia elimina muitos empregos, os postos criados demandam cada vez mais habilidades e conhecimentos".

Para Schön (1983) as profissões estão passando por uma crise crescente no que se refere à confiança, pois os profissionais estariam sendo chamados a desempenhar tarefas para as quais não foram educados. Esta situação é desencadeada tanto pela acelerada mudança tecnológica pela qual as sociedades vêm passando, como pela racionalidade técnica, do currículo, que não é suficiente.

O corpo de conhecimentos que o profissional adquire, não está associado ao conhecimento profissional com características próprias de situações da prática, ou seja, com situações que geram instabilidade, complexidade, incerteza, conflito de valores e sendo que estas características, não são resolvidas com o emprego de conhecimentos especializados e de tarefas bem definidas. Ainda para o mesmo autor, uma possibilidade para resolver esta crise é o exercício reflexivo na ação profissional. 
Analisando os períodos mais recentes do ensino de enfermagem, concordamos com Baptista, Barreira (1999, p.77) que afirmam que

\begin{abstract}
as educadoras de enfermagem, atuaram intencionalmente no sentido de adequar os currículos dos cursos de graduação e pós-graduação aos propósitos de melhor inserção da enfermagem na universidade e na comunidade científica, mas apesar destas iniciativas, o momento atual exige renovados esforços de docentes e estudantes de enfermagem no sentido de garantirem as posições já conquistadas e de elaborarem um projeto de ensino como contribuição ao desenvolvimento da enfermagem no Brasil.
\end{abstract}

Enquanto prática social e profissional, a Enfermagem precisa acompanhar as transformações sociais, políticas e econômicas, além dos avanços tecnológicos e científicos, e para tanto, os docentes necessitam estar capacitados para atuar, com competência, no processo de formação dos futuros profissionais de enfermagem.

Para tanto, conforme Sordi, Sampaio, Alves e Adão (1999, p.245), os docentes deverão reorganizar e priorizar as competências que norteiam a formação dos enfermeiros, entre estas a atualização dos saberes técnicos e científicos, bem como a presença da pesquisa no cotidiano, possibilitando que os graduandos possam estabelecer pensamento crítico-reflexivo, com contextualização dos conhecimentos em relação à sociedade e à realidade do mundo do trabalho. 


\section{V - PERCURSO METODOLÓGICO}

\section{1 - A escolha da metodologia}

Para o presente estudo, considerando que o objeto a ser investigado pertence a uma realidade ligada ao mundo dos significados, das crenças pessoais e, portanto do campo da subjetividade, optamos por uma proposta metodológica qualitativa.

Partindo desta premissa e observando o contexto em que estamos inseridos como docente, adotamos a modalidade da Pesquisa-Ação para esta pesqui$\mathrm{sa}$, que foi estruturada em dois momentos subseqüentes, compreendendo entrevistas semi-estruturadas, cujos dados coletados foram tratados a partir da análise de conteúdo com base na análise temática, e com grupo focal, que teve seus dados analisados de acordo com a metodologia proposta pela hermenêuticadialética, como adiante citado.

\section{2 - A Pesquisa-Ação}

A expressão Pesquisa-Ação surgiu na psicologia social com Kurt Lewin na década de 40, cujos princípios eram o de caráter participativo, de impulso democrático e de contribuição para a mudança social. Dessa forma a PesquisaAção como metodologia se desenvolve e conforme Haguette (1999) se consolida mediante a idéia da possibilidade de intervenção na vida social, no intuito de transformá-la.

Desde sua criação, as pesquisas consideradas ativas adotaram concepções e práticas diversas, muitas vezes distanciando-se e, até opondo-se, à proposta original de Kurt Lewin. Entretanto, todos esses movimentos preservaram a 
essência que caracteriza o uso do termo pesquisa-ação, que é a preocupação com a melhoria da prática.

Nesta direção, a Pesquisa-Ação, é uma estratégia metodológica da pesquisa social, um instrumento de trabalho e de investigação em instituições, grupos e comunidade de pequeno e ou médio porte, sendo o principal objetivo dessa proposta, proporcionar aos pesquisadores e grupos de participantes os meios de se tornarem capazes para superar com maior eficiência os problemas da situação em que vivem, em particular, sob a forma de diretrizes de ações transformadora. Segundo Thiollent (1994, p.19) "com a pesquisa-ação é possível estudar dinamicamente os problemas, decisões, ações, negociações, conflitos e tomadas de consciência que ocorrem entre os agentes durante o processo de transformação da situação".

A Pesquisa-Ação caracteriza-se por uma interação ampla e manifesta entre o pesquisador e os sujeitos envolvidos na situação a ser investigada e dessa forma, um e outro são atuantes no processo de suscitar questões que requeiram soluções concretas, que possibilitem a ampliação do nível de consciência do grupo em relação a estas questões, levando em consideração o contexto social em que estas ocorrem.

Haguette (1999) refere que em virtude de sua essência ser voltada para a prática e tendo como principal característica a intervenção, a Pesquisa-Ação pode ser aplicada de forma variada, tais como: ações integradoras que propiciem a auto-regulação do objeto de estudo, seja o indivíduo ou o grupo social, mudanças não radicais e, ainda, lutas por transformações revolucionárias.

A Pesquisa-Ação pode ser aplicada em diferentes áreas, como na educação, comunicação social, serviço social, organizações, tecnologia e nas práticas políticas e sindicais.

Na área de educação, a orientação metodológica da pesquisa-ação proporciona condições, ao pesquisador, de produzir informações e conhecimentos de emprego real e efetivo.

A contribuição, neste caso, está direcionada para a elucidação de situações escolares, para a definição de objetivos de ação pedagógica e de transformações mais amplas.

Para Thiollent (op.cit,p.75), "a Pesquisa-Ação promove a participação dos usuários do sistema escolar na busca de solução de seus problemas”. Dessa forma é esperado que uma linguagem apropriada seja utilizada pelo pesquisador, 
possibilitando, por meio desta linguagem, que os objetivos teóricos da pesquisa sejam continuamente assegurados.

Segundo Pereira (2000), a Pesquisa-Ação na área da educação, favorece a integração entre o "ensino e o desenvolvimento do professor, desenvolvimento do currículo e avaliação, pesquisa e reflexão filosófica em uma concepção holística de prática reflexiva educativa".

Nesta direção, o pesquisador deve converter o conhecimento já explicitado em hipóteses-ação, procurando relacionar o contexto específico, a teoria e a ação com o propósito maior de compreender e aperfeiçoar a prática educativa.

Segundo Thiollent (1994), quando optamos pela Pesquisa-Ação, não há um rigor em seguir etapas ou fases, que normalmente são constituídas por uma situação inicial, delineamento de objetivos, planejamento de ações e, finalmente, a execução e avaliação destas ações. Ainda segundo o autor, o mais importante é estabelecer um ponto de partida, designado fase exploratória e um ponto de chegada, designado divulgação de resultados, sendo que, o percurso entre o início e o fim pode conter inúmeros caminhos que serão escolhidos de acordo com os acontecimentos da pesquisa. Esta flexibilidade permite um vaivém na situação de investigação, concebendo a pesquisa-ação de modo amplo e para tanto, propõe etapas que poderão ou não compor a trajetória metodológica da pesquisa-ação.

A fase exploratória baseia-se na elaboração de um diagnóstico, ou seja, na exploração do campo de pesquisa, em conhecer as pessoas interessadas e quais as suas expectativas em relação ao trabalho a ser desenvolvido. Ainda nesta fase, é possível o levantamento de problemas e de eventuais ações.

Após conhecer todos estes aspectos, são estabelecidos os objetivos principais da pesquisa pelo pesquisador e participantes pertinentes ao campo de investigação, aos atores, aos problemas identificados como prioritários e ao tipo de ação que se pretende, durante a investigação.

O tema da pesquisa é determinado do problema prático e da área de conhecimento que se pretende conhecer. Para tanto, é necessário que pesquisador e participantes conheçam a natureza e as dimensões dos problemas designados pelo tema, pois, a pesquisa será organizada de modo a propor, soluções, intervenções ou transformações.

Estas "soluções" são possíveis, mediante as interpretações de determinadas categorias de dados, pelo estabelecimento de um marco referencial teórico que direciona a pesquisa. 
Thiollent (1994, p.45), considera ainda "que o projeto de pesquisa-ação precisa ser articulado dentro de uma problemática com um quadro de referência teórica adaptado a diversos setores". Dessa forma a função da teoria é a de criar idéias, hipóteses ou ainda diretrizes para nortear a pesquisa e as interpretações.

A hipótese desempenha uma função considerável na organização da pesquisa, pois, a partir da sua elaboração, podemos identificar as informações necessárias, impedir a dispersão, manter centralizadas determinadas partes do campo de observação e ainda eleger os dados a serem utilizados na pesquisa.

Segundo este mesmo autor (op.cit, p.56), a hipótese qualitativa quando para fins descritivos, "é utilizada para organizar a pesquisa em torno de possíveis conexões ou implicações não-causais, mas suficientemente precisas para estabelecer que $\mathrm{X}$ tem algo a ver com $\mathrm{Y}$ na situação considerada".

O campo de observação para o desenvolvimento da pesquisa segundo a metodologia da pesquisa-ação possui grande abrangência de delimitação, desde comunidades, concentradas ou não, até a delimitação de um quadro de atuação dentro de uma instituição ou universidade.

A amostragem e a representatividade qualitativa na pesquisa-ação não se dá necessariamente pelo critério quantitativo, mas deve-se considerar a representatividade sócio-política de grupos, ou de opiniões, que são minoritários em termos numéricos, mas expressivos das circunstâncias em termos ideológicos e políticos. Para Thiollent (op.cit,p.63), "a representatividade expressiva (ou qualitativa) é dada por uma avaliação da relevância política dos grupos e das idéias que veiculam dentro de uma certa conjuntura ou movimento".

A coleta de dados pode ser realizada de diversas formas. Para Haguette (1999), na pesquisa-ação, o uso de dinâmicas de grupo é a técnica de excelência, entretanto, podem ser utilizadas ainda, as entrevistas coletivas ou individuais, a observação participante, os diários de campo, a história de vida e outros.

Para o desenvolvimento adequado da pesquisa-ação, no atendimento de seus objetivos, é fundamental o estabelecimento de um plano de ação, considerando que os participantes são os sujeitos dentro do contexto ou da organização que se pretende observar.

Segundo Thiollent (1994, p.70),"a ação corresponde ao que precisa ser feito (ou transformado) para realizar a solução de um determinado problema" podendo haver vários tipos de ação: educativas, comunicativa, técnica, política, cultural e outras, dependendo do campo de atuação e da problemática adotada. 
Considera ainda que "as implicações da ação aos níveis individuais e coletivos devem ser explicitadas e avaliadas em termos realistas, evitando criar falsas expectativas entre os participantes no que diz respeito aos problemas da sociedade global" (idem, p.71).

Vale ressaltar que este autor deixa clara a existência de três níveis: grupos e indivíduos, instituições intermediárias e sociedade global em que poderão ocorrer inter-relações entre estes níveis, daí a necessidade de definir o real alcance da proposta transformadora da pesquisa.

Em relação à conscientização e à comunicação, as transformações se propagam por meio do discurso, da denúncia, do debate ou da discussão. Dessa forma, o que é transformado na verdade, são as representações a respeito das situações em que atuam os sujeitos da pesquisa, incluindo os seus sentimentos.

$\mathrm{Na}$ pesquisa-ação não há critérios únicos para estimar o alcance das transformações, pois, cada situação apresenta singularidades em relação a outras. Os resultados podem ser alcançados em termos de transformação, ao serem avaliados, quando as ações adquirem uma dimensão objetiva de fácil identificação, por exemplo, quando percebemos produção ou manifestação coletiva.

Para Thiollent (op.cit.p.43), "a ação é acoplada à esfera dos fatores subjetivos e, portanto, faz-se mister distinguir vários graus na tomada de consciência". Para tanto referenda Paulo Freire, que considera importante e distingue pelo menos dois graus: a tomada de consciência restrita a uma aproximação espontânea, sem caráter crítico e, a conscientização que possibilita revelar uma nova realidade pelo desenvolvimento crítico.

A divulgação dos resultados aos participantes, para este mesmo autor, é importante, pois "exerce um efeito de síntese" de todo o trabalho realizado e principalmente, um efeito de conviçcão entre os participantes. Esta ação poderá "gerar reações e contribuir para a dinâmica da tomada de consciência e, eventualmente, sugerir o início de mais um ciclo da ação e de investigação" (id.ibidem). 


\section{3 - O Ambiente da Pesquisa}

\subsection{1 - Breve histórico do ensino Católico Superior no Brasil}

A universidade católica, no Brasil, segundo Camargo (1989, p.15), surgiu como resultado de um projeto da Igreja, representando "uma reação aos movimentos políticos religiosos e culturais, originários da segunda metade do século XIX, cujas bandeiras eram o positivismo, o liberalismo político e a laicização do ensino e da cultura".

Com a Proclamação da República em 1889 e a promulgação da nova Constituição Republicana, foram rompidos os laços políticos da Igreja com a Monarquia e com o governo estabelecido, sendo impedido o ensino religioso nas escolas oficiais. Anteriormente a este ato, a Igreja Católica no Brasil se remetia ao Imperador, que assumia o papel de intermediação junto à Santa Sé, pelo estabelecimento do Padroado. Para assegurar sua autonomia e identidade como Instituição, a Igreja Católica buscou fortalecer os quadros eclesiásticos, tendo a ação religiosa sido organizada e o contato com a Santa Sé passou a ser direto.

Em termos mundiais, com a instalação do Estado Socialista na Rússia em 1917, a Igreja elaborou um Código de Direito Canônico, regulamentado em 1929 pela encíclica papal denominada Divini illius Magistri, que em conjunto com aquele código estabeleciam, segundo Danilo Lima (1978) apud Cunha (1986, p.285)

\footnotetext{
ser proibido aos católicos colocarem seus filhos em escolas leigas, fossem elas únicas (obrigatórias para todos) ou mistas (com ensino religioso separado do resto da instrução), além de condenarem a coeducação(, isto é, a presença de alunos de ambos os sexos na mesma sala. Os dois documentos atacavam a tendência do Estado de assumir o controle da educação escolar, pois temiam a possibilidade das escolas serem usadas para a pregação de doutrinas contrárias à católica.
}

As atividades político-religiosas da Igreja Católica no Brasil foram reformuladas e organizadas no período de 1920 e 1930, no intuito de combater a influência dos movimentos já citados, advindos, com as novas idéias, dos imigrantes europeus. Nesta época, descreve Cunha (1986, p.286), o Arcebispo de Olinda e Recife expediu em 1916 uma Carta Pastoral reivindicando a retomada do ensino religioso nas escolas oficiais.

Durante a Primeira Guerra Mundial, mesmo contra o laicismo republicano, a Igreja Católica se aliou ao governo para defender a "ordem e o progresso", te- 
mendo o risco de penetração de idéias socialistas, nas instituições e nos valores nacionais estabelecidos.

Outrossim, a classe dominante, principalmente os setores oligárquicos receberam apoio da Igreja. Dessa forma a Igreja se fortificou politicamente, demonstrando defesa, ao país, ante as ameaças comunistas e pela conformidade dos interesses entre as classes sócio-economicamente organizadas.

Segundo Camargo (1989, p.18),

O projeto político-cultural da Igreja Católica no Brasil, no início deste século, após o rompimento do Padroado, foi o de ganhar identidade, enquanto poder espiritual e de influir no poder temporal, para garantir as suas prerrogativas. Nessa perspectiva, a cristianização da elite cultural e mesmo política do país se constituiu numa importante meta, assumida pela criação da universidade. Longe de atender apenas a busca da 'base espiritual da cultura', a universidade católica também contribuiu para o fortalecimento das classes dominantes da época e manutenção do "status quo".

Em 1931, Francisco Campos, então titular do recém criado Ministério da Educação e Saúde Pública, por intermédio do Decreto 19.941 de 30 de Abril de 1931, autoriza o retorno do ensino católico ao currículo das escolas primárias, secundárias e normais, justificando a medida por ser, conforme Cunha (1986, p.288),

[...] uma conquista do catolicismo contra o 'dogma da liberdade de pensamento' defendido pelos liberais, e, provisoriamente, pelos comunistas, interessados em destruir as 'instituições nacionais'.

Em 1932, foi criado o Instituto Católico de Estudos Superiores, sendo este evento declarado o lançamento da semente da universidade católica no Brasil. No final da década de 30, o Vaticano manifestou a sua intenção em criar a Universidade Católica no Brasil.

Finalmente, em 1940, foram traçadas as linhas fundamentais da mantenedora das faculdades católicas, resultando na criação de várias instituições católicas de ensino superior.

A partir de 1945, a transformação da sociedade, subordinando o humano, o social e o científico ao econômico desencadeado pelo capitalismo monopolista, pelo processo desenvolvimentista e a aceleração industrial, teve profundo reflexo na universidade. Diante deste cenário, a Igreja propôs segundo Camargo (1989, p.18), "um novo marco doutrinal que substitui a idéia de reforma das estruturas sociais pela sua transformação, no sentido da justiça social, da vivência democrática". 
Assim, continua a autora, o ensino superior católico em seu perfil educativo assume uma nova forma. A universidade passa a ser concebida como centro de educação, ensino e investigação crítica, onde se pretende formar o sujeito histórico, emancipado, compromissado com a humanização das estruturas sociais.

Em 1946 as Faculdades de Filosofia, Ciências e Letras, de Ciências Econômicas e Escola de Biblioteconomia existentes na cidade de Campinas, foram agregadas à Universidade Católica de São Paulo. Após alcançar o número de cursos exigidos pela legislação vigente, em 1955, foi constituída a Universidade Católica de Campinas, desmembrando-se da Universidade Católica de São Paulo.

Em 1972, recebeu do Vaticano o Título de Pontifícia, tornando-se Pontifícia Universidade Católica de Campinas, adotando a sigla PUCCAMP inicialmente, posteriormente alterada para PUC-Campinas.

\subsection{2 - O "lócus" do estudo}

No período entre 1950 e 1967 a Universidade Católica de Campinas manteve a ela agregada, a Escola de Enfermagem Madre Maria Teodora Vairon, reconhecida pelo Decreto ํo 28.373 de 12 de julho de 1950 .

Em 1972 o Conselho Universitário da PUC-Campinas aprovou a abertura da Faculdade de Enfermagem que teve seu reconhecimento pelo Decreto Lei № 79.088 de 04 de janeiro de 1977.

Após reforma da estrutura administrativa da Universidade em 2002, já com a atual denominação de Curso de Enfermagem, passou a integrar, com os demais cursos da área da saúde, o Centro de Ciências da Vida (CCV), funcionando no Campus II da PUC-Campinas. Assim, o lócus do presente estudo é o Curso de Enfermagem da PUC- Campinas.

\section{4 - Os Sujeitos da Pesquisa}

Na presente investigação, o objeto a ser pesquisado são as competências para ser docente de enfermagem, buscando conhecer um percurso históricocultural, individual e coletivo vivido pelos sujeitos da pesquisa, que são enfermei- 
ros docentes de disciplinas de enfermagem do curso de Enfermagem da PUCCampinas.

Como critérios de inclusão do docente para participação no primeiro momento da presente pesquisa (entrevistas), foram considerados: pertencer à área de saber específico de enfermagem e ter no mínimo cinco anos de atividade contínua no corpo docente do Curso de Enfermagem da PUC-Campinas.

Assim, do total de 38 enfermeiros integrantes do corpo docente no $2^{\circ}$ Semestre de 2005, dez professores correspondiam aos critérios estabelecidos, dos quais nove concordaram em participar voluntariamente das entrevistas da primeira fase, mediante apreciação do Projeto de Pesquisa e assentimento formal do Termo de Consentimento Livre e Esclarecido (Anexo 3).

Conforme os dados individuais das nove docentes participantes da primeira fase, todas são do sexo feminino e pertencem à faixa etária de 35 a 55 anos; tem tempo de formação que varia de 12 a 29 anos e todas tem especialização (e/ou Residência) na área técnica. Das 9 entrevistadas, 8 possuem Mestrado, sendo 6 na área de Educação e 2 na área de Enfermagem. Destas 9 docentes entrevistadas, 6 possuem Doutorado (sendo 1 na área de Educação e 5 na área de Enfermagem), observando-se ainda que do total, 3 possuem entre 12 e 18 anos de experiência na docência e seis entre 24 e 29 anos de docência.

Para o segundo momento da pesquisa (grupo focal), foram convidados os 38 professores do curso de Enfermagem, dos quais 6 participaram voluntariamente, mediante assentimento formal do Termo de Consentimento Livre e Esclarecido (Anexo 5).

Segundo os dados individuais das 6 docentes participantes da segunda fase, todas são do sexo feminino e pertencem à faixa etária de 35 a 55 anos; tem tempo de formação variando de 10 a 30 anos, todas com especialização (e/ou residência) na área técnica. Das 6 entrevistadas, 5 são Mestres, sendo 2 na área de Educação e 3 na área de Enfermagem, enquanto uma docente está cursando mestrado em Enfermagem. Destas 6 docentes, 5 possuem o título de Doutor (sendo uma na área de Educação e 4 na área de Enfermagem), observando-se ainda que do total, 3 possuem entre 3 e 18 anos de experiência na docência e 6 entre 24 e 29 anos de docência. 


\section{5 - A preservação dos aspectos éticos da pesquisa.}

Os aspectos éticos desta pesquisa foram preservados segundo a Resolução no 196 de 10 de outubro de 1996 do Conselho Nacional de Saúde do Ministério de Estado da Saúde, que aprova as diretrizes e normas regulamentadoras de pesquisas envolvendo seres humanos e somente foram realizadas, após parecer favorável do Comitê de Ética em Pesquisa da Escola de Enfermagem da Universidade de São Paulo (Anexo 2), e após o consentimento e autorização para a coleta de dados, pela Instituição, representada pela Direção da Faculdade de Enfermagem da PUC- Campinas (Anexo 1).

Os nomes dos entrevistados foram mantidos em sigilo, utilizando-se, para tanto, codificação numérica na primeira fase para o registro das falas e nome de flores, às falas resgatadas no Grupo Focal, o que assegura o anonimato dos sujeitos da pesquisa.

\section{6 - A coleta de dados}

A coleta de dados teve início com entrevistas individuais com as nove docentes selecionadas a partir do critério estabelecido, após a aceitação voluntária das mesmas. As entrevistas foram previamente agendadas conforme a disponibilidade das entrevistadas e gravadas para posterior transcrição, e foram orientadas por três questões:

1 - Como ocorreu sua capacitação para ser docente de enfermagem e quais competências julga que desenvolveu?

2 - Como você percebe que ocorre sua capacitação hoje e quais competências julga estar desenvolvendo?

3 - Como você pensa que deva ser a continuidade desta capacitação e quais competências julga que deva desenvolver?

Em um segundo momento como fonte de informação, recorremos à técnica de grupo focal. Seis aceitaram participar, voluntariamente, desta fase do estudo e todo relato de experiência por eles vivida foi considerado válido.

Para a constituição do grupo focal, foi encaminhada uma carta-convite para todos os professores enfermeiros do curso de enfermagem, com informações, 
sobre esta atividade, bem como data, local, horário de início e término da mesma, observando-se que a presença deveria ser confirmada até 24 horas antes da reunião por telefone ou pessoalmente. De forma similar aos procedimentos das entrevistas realizadas, para o grupo focal, houve a formalização de Termo Consentimento Livre e esclarecido, bem como a permissão de utilização dos dados da pesquisa, que foram gravados. (Anexo 5 )

\section{7 - A análise dos dados}

A análise e interpretação dos dados ocorreram em duas etapas sucessivas, sendo a primeira, a partir das respostas advindas das entrevistas com os docentes, cujas falas/discursos foram analisados, pela pesquisadora, segundo a técnica da análise de conteúdo, gerando um relatório síntese.

Este relatório síntese, proveniente das entrevistas, constituiu o material que foi submetido para discussão e reflexão no grupo focal, compondo o segundo momento da pesquisa.

Os dados obtidos no encontro do grupo focal foram analisados segundo a hermenêutica dialética e com o auxílio de determinantes segundo o materialismo histórico-dialético, conforme explicitado adiante, permitindo a construção dos resultados do estudo.

\subsection{1 - Análise de Conteúdo}

A análise de conteúdo é considerada mais do que um procedimento técnico, por ser historicamente constituído na busca teórica e prática no campo das investigações sociais. Este fato leva o pesquisador à tradicional discussão sobre a especificidade do conteúdo próprio das ciências sociais, principalmente quanto à sua significação. Minayo (1996, p.200) diz que

[...] historicamente, a Análise de Conteúdo Clássica tem oscilado entre o rigor da suposta objetividade dos números e a fecundidade da subjetividade. A grande importância dessa técnica de função heurística tem sido a de impor um corte entre as instituições e as hipóteses que encaminham para interpretações mais definitivas. Essa tentativa faz parte de um esforço teórico secular. 
Nas áreas da Sociologia, Antropologia, Psicologia, Psicanálise e Jornalismo, existem discussões sobre tal técnica de pesquisa, envolvendo fatores que sustentam o debate teórico e técnico, bem como pontos de vista polêmicos nos planos epistemológico e metodológico. Contudo, todo o empenho teórico para o desenvolvimento de técnicas propõe exceder o nível do senso comum e do subjetivismo na interpretação, alcançando vigilância crítica diante da comunicação de documentos, textos literários, biografias, entrevistas e observação.

A Análise de Conteúdo está firmada nos pressupostos de uma concepção dinâmica da linguagem aqui entendida como legitima construção da sociedade, que expressa o sentido da existência humana, em diferentes momentos históricos, elaborando e desenvolvendo representações sociais advindas da relação dinâmica que se estabelece entre linguagem, pensamento e ação. Entende-se ainda, por Análise de Conteúdo, um conjunto de técnicas de análise das comunicações.

Para Mucchielli (1977, p.26), a Análise de Conteúdo é uma questão de semântica e se constitui em uma técnica de pesquisa que tem, por objetivo, a procura do sentido ou dos sentidos encontrados em um texto. Segundo o autor,

na lingüística tradicional, a condenação de todo o recurso ao sentido elevou o rigor científico em relação à descrição das estruturas formais da língua. Todavia, a semântica (assim excluída) é justamente o pão cotidiano da análise de conteúdo. Semântica entendida não como estudo do vocabulário da língua em geral, mas como a pesquisa do sentido de um texto. (idem, p.27)

Bardin (1977, p.31), por sua vez, conceitua este método como sendo

um conjunto de técnicas de análises de comunicação que visa a obter, por procedimentos sistemáticos e objetivos de descrição do conteúdo das mensagens, indicadores (quantitativo ou não) que permitam a inferência de conhecimentos relativos às condições de produção (recepção de variáveis inferidas) destas mensagens.

Historicamente, tem-se conhecimento sobre a Análise de Conteúdo desde o ano de 1640, mas somente em 1927 passou a ser visto com o rigor científico do método, quando foi editado por Lasswell o livro "Propaganda Technique in the world". Além dele, continua Minayo (1996, p.201), Berelson e Lazarfeld são também considerados marcos criadores da utilização da Análise de Discurso como método, desmascarando jornais e periódicos suspeitos e que eram considerados subversivos e nazistas. 
A polêmica entre a abordagem quantitativa e qualitativa no estudo do material foi aprofundada quando do seu fortalecimento epistemológico a partir dos anos 50 e na década de 60 do século XX.

A Análise de Conteúdo tem uso variado e pode ser aplicado em entrevistas e conversações, respostas escritas de questionários, textos variados, comunicação não verbal ou outros percebidos pelo pesquisador.

Ainda segundo a autora (op cit,p.203), operacionalmente, a análise de conteúdo principia de uma leitura superficial e generalizada, para alcançar um nível mais profundo, ou seja, "aquele que ultrapassa os significados manifestos". Para tanto, a análise de conteúdo expõe estruturas semânticas que são significantes, com estruturas sociológicas que contém os significados dos enunciados, neste caso, nas entrevistas.

Várias técnicas de Análise de Conteúdo têm sido desenvolvidas, no intuito de alcançar os significados manifestos e latentes no material selecionado. São elas: Análise de Expressão, Análise de Relações, Análise da Enunciação e Análise Temática, sendo esta última escolhida para o estudo em questão, por apontar o tema como unidade de significado que permitem identificar os pontos relevantes ou núcleos de sentido que compõe as comunicações dos sujeitos da pesquisa, caracterizados pela importância das unidades de significado detectadas.

Para Minayo (1996, p.208), "a noção de tema está ligada a uma afirmação a respeito de determinado assunto. Ela comporta um feixe de relações e pode ser graficamente apresentada através de uma palavra, uma frase, um resumo".

Já para Bardin (1977, p.105), "o tema é a unidade de significado que se liberta naturalmente de um texto analisado segundo critérios relativos à teoria que serve de guia à leitura."

Realizar uma análise temática segundo Minayo (1996, p.209)

Consiste em descobrir os núcleos de sentido que compõem uma comunicação cuja presença ou freqüência signifiquem alguma coisa para o objetivo analítico visado. Ou seja, tradicionalmente, a análise temática se encaminha para a contagem de freqüência das unidades de significado como definitórias do caráter do discurso. Ou, ao contrário, qualitativamente a presença de determinados temas denota os valores de referência e os modelos de comportamento presentes no discurso.

A operacionalização da análise temática se dá em três fases: a préanálise, a exploração do material e o tratamento dos resultados. A pré-análise é considerada a fase organizativa do estudo, onde todo material a ser analisado deve ser disposto e submetido a uma leitura que parte do geral para o específico. É 
a fase em que ocorre a seleção de documentos a serem analisados, onde as hipóteses e os objetivos serão reformulados e ainda, a elaboração de indicadores que fundamentarão a interpretação final.

A fase denominada exploração do material é a análise propriamente dita. É a realização sistemática do recorte, codificação e enumeração dos índices e indicadores, resgate das unidades de registro e categorização. Esta fase constitui um momento extenso do estudo, pois requer um movimento de ir e vir dos textos no intuito de explorar o material disponível, culminando nas categorias.

O objetivo da categorização é fornecer, ao pesquisador, uma transformação dos dados brutos que são encontrados nos textos em informações com significado sobre o estudo proposto.

A fase denominada tratamento dos resultados permite, ao pesquisador propor inferências e fazer posteriores interpretações prenunciadas no quadro teórico, ou ainda vislumbrar novas frentes, servindo de base para uma outra análise, sugerida pela leitura do material, para novas dimensões teóricas, realizado na segunda fase da pesquisa, segundo a técnica de grupo focal.

\subsection{2 - O Grupo Focal}

Grupo Focal é uma técnica de pesquisa que vêm sendo utilizada com bastante freqüência na área de saúde, especialmente em pesquisas qualitativas, onde se pretende aprofundar ou conhecer um determinado foco ou ainda temas específicos. É utilizada para coleta de dados, análise, avaliação e validação, com informações qualitativas.

Segundo Whestphal, Bogus e Faria (1996, p.473) "grupo focal é uma técnica de pesquisa que utiliza as sessões grupais como um dos foros facilitadores da expressão de características psicossociológicas e culturais".

Para Ressel, Gualda e Gonzales (2002), a técnica de grupos focais favorece a apreensão das diferentes visões de mundo sobre determinado tema ou foco, quando se quer compreender de forma mais aprofundada um comportamento, dentro de um determinado grupo e ainda por possibilitar a construção de um conhecimento coletivo a partir de fórum de discussão grupal. 
Whestphal, Bogus e Faria (1996, p.473) referem que esta técnica permite, aos participantes, a expressão de suas percepções, crenças, valores, atitudes e representações sociais referente a um determinado assunto.

Já Dall'agnoll e Trench (1999) afirmam que nesta técnica, cada membro do grupo se expressa a partir de uma experiência vivida e a inter-relação das várias experiências é que permitirá a fluência da discussão. A partir desta discussão é que emergem os comportamentos, as opiniões, etc, que permitem atingir o objetivo proposto no estudo.

A sistemática da operacionalização de um grupo focal, segundo Whestphal, Bogus e Faria (id.ibid), considera inicialmente, a clareza sobre o tema, o foco e a questão a ser investigada, avaliada, ou aprofundada. São necessárias as presenças de um facilitador e a de um ou dois observadores para anotar a discussão, cada um com características, papéis e funções específicas.

O facilitador deve ser um profissional com experiência na condução de grupos, ser sensível, capaz de ouvir, ser flexível, expressar-se com clareza e ter senso de humor. O papel do facilitador está na habilidade de conduzir a discussão, que depende do objeto de estudo que está sendo avaliado ou investigado e da natureza das informações que se pretende obter.

Dessa forma, o facilitador pode não intervir na discussão, procurando apenas manter um clima favorável à discussão, controlando o tempo e estimulando a participação de todos. Além disso, o facilitador pode guiar a discussão com formulação de perguntar abertas sem, entretanto, induzir o grupo, a dar respostas que o facilitador deseja ouvir. Deve ainda evitar a monopolização da discussão por um dos participantes e estar atento às expressões não verbais e saber interpretá-las a fim de intervir e enriquecer a discussão.

O papel do observador, segundo Whestphal, Bogus e Faria (1996, p.473), é o de "captar e registrar as informações não verbais expressas pelos participantes e, ao final, ajudar o facilitador a analisar os possíveis vieses ocasionados por problemas na sua forma de coordenar a sessão".

A composição do grupo focal deverá ser homogênea e ao mesmo tempo preservar certas particularidades heterogêneas e assim, aspectos como idade, sexo, experiência profissional e outros, são características homogêneas facilitadoras para a discussão. 
A seleção dos participantes poderá variar, dependendo do estudo, podendo ser criados critérios de seleção, e ser feita uma pré-seleção para identificar os que melhor se enquadram nos critérios definidos.

O local para a atividade deve ser sem ruídos, amplo, arejado, bem iluminado e a disposição em que deverão se acomodar os participantes deve ser em mesa que comporte a todos, em cadeiras confortáveis e em distância entre cada um que permita a visualização pelo facilitador, de todo o grupo.

Inicialmente, as informações sobre o quê será estudado no grupo focal, devem ser passadas aos participantes de maneira superficial, para que não compareçam com idéias preconcebidas sobre o tema. Quanto ao tamanho do grupo, a participação deve ser de no mínimo 6 e no máximo 15 pessoas e pode ocorrer o mesmo estudo em grupos diferentes, dependendo do número de pessoas interessadas em participar.

Constituído o grupo, o facilitador inicia a atividade fazendo uma breve explanação da proposta, agradecendo a participação de todos, se for necessário uma auto-apresentação e ainda um cartão de identificação para cada participante. Aproveita-se o momento para entregar, a cada participante, um Termo de Consentimento Livre e Esclarecido com esclarecimentos sobre a pesquisa e o consentimento de utilização dos dados.

Neste momento, devem-se explicar os objetivos do encontro, como se deu a seleção dos participantes, informando ainda, a necessidade de se utilizar o gravador para registro das falas; quais os papeis do facilitador e do observador, bem como informar o horário de término da reunião e como se dará o desenvolvimento da atividade, que poderá ser por meio de perguntas ou outras técnicas investigativas como dinâmicas lúdicas ou ambas, no intuito de incentivar e organizar a discussão.

Após posterior transcrição das falas, os dados coletados são analisados conforme a metodologia adotada a qual, na presente pesquisa, foi a hermenêutica dialética, conforme descrito a seguir.

\subsection{3 - Hermenêutica Dialética}

A escolha da hermenêutica-dialética como método, em dado momento da pesquisa, pareceu-nos o caminho mais coerente com os objetivos propostos, para 
dar relevância à práxis, levando em consideração Minayo (1996, p.219), que afirma:

\begin{abstract}
A hermenêutica e a dialética não devam ser 'encurtadas' através de sua redução à simples teoria de tratamento de dados. Mas pela sua capacidade de realizar uma reflexão fundamental que ao mesmo tempo não se separa da práxis, podemos dizer que o casamento dessas duas abordagens deve preceder e iluminar qualquer trabalho científico de compreensão da comunicação.
\end{abstract}

Hermenêutica, segundo Lalande (1999) apud Minayo (2005), "é a interpretação dos textos filosóficos ou religiosos e especialmente a Bíblia (Hermenêutica Sagrada). Esta palavra aplica-se, sobretudo à interpretação daquilo que é simbólico". Para Ferrater Mora (1984) também citado por Minayo (1996, p.219), "hermenêutica consiste na explicação e interpretação de um pensamento", podendo ser literal ou temática. Literal, quando envolve o estudo do sentido das expressões usadas por meio de uma análise lingüística, e "temática, na qual importa mais que a expressão verbal, a compreensão simbólica de uma realidade a ser penetrada".

A arte de interpretar, segundo o filósofo alemão Wilhein Dilthey ${ }^{51}$, nasceu na Grécia, a partir da necessidade de ensinar, face às contradições de entendimento dos textos clássicos como os de Homero. Segundo o autor, a hermenêutica foi se estruturando com a retórica, com os sofistas e, com Aristóteles, ganhou consistência científica.

Nesta direção, um novo passo foi dado com a Filologia Alexandrina, como a arte de recensear textos, criticando-os, interpretando-os e avaliando-os, a fim de afastar inverdades.

Neste mesmo período, foi introduzido por Crates de Mallos ${ }^{52}$ o início da rigidez e da austeridade na interpretação simbólica, eliminando a contradição existente entre documentos religiosos antigos e uma filosofia progressista.

A partir deste evento, a hermenêutica passou a ser usada para a interpretação de textos sagrados de forma mais metódica, iniciando uma disputa teológi-

\footnotetext{
${ }^{51}$ Wilhelm Dilthey (1833-1911) foi um notável filósofo historicista alemão, nascido em Biebrich-Mosbach (Wiesbaden-Biebrich), estudou na Universidade de Berlim, tendo sua tese de habilitação na Faculdade de Filosofia de Berlim, em 1864. Foi nomeado Professor na Universidade de Bale (Basiléia), Suíça em 1867 e na de Kiel em 1868, a partir de 1882, passa a catedrático da Universidade de Berlim, até ao final de sua vida. Dilthey elaborou uma teoria do conhecimento para as ciências do espírito, em que destaca 0 conhecimento histórico, sistema conhecido por historicismo, que se apoiava particularmente no estudo da história. O historicismo tem algo de paralelo com as filosofias que tratam toda a realidade como um devir, como no caso do elã vital da filosofia de Bergson, ou como no devir vital do sistema de Klages. Cf.Encarnação (2006).

${ }^{52}$ Foi um eminente gramático grego, que desenhou um mapa mundi chamado de "mapa de Crates" e viveu no século I AC, tendo se destacado por inúmeros estudos sobre a dialética antiga.
} 
ca entre a Igreja Cristã, os judeus e os gnósticos ${ }^{53}$, na interpretação de textos bíblicos. Deste conflito, surgiram as primeiras teorias hermenêuticas que foram adquirindo um caráter ainda mais científico.

A Hermenêutica tem como característica intrínseca o dever de ser mais construtiva e criativa e dessa forma, quando do surgimento do Renascimento, a Hermenêutica encontrava-se em um estado mais avançado, possibilitando o início de uma nova etapa de seu desenvolvimento, tendo em vista o terreno favorável decorrente do Renascimento.

Durante quatro séculos, uma vasta literatura hermenêutica é dominada por duas grandes correntes de pensadores, das quais uma buscava compreender as obras clássicas e a outra, os textos bíblicos, quase que como uma divisão entre o sagrado e o clássico.

Segundo Dilthey, a constituição da Hermenêutica deve-se à interpretação bíblica, pois como anteriormente, a disputa teológica teve segmento, agora, entre os movimentos da reforma e contra-reforma.

A Hermenêutica Clássica e Sagrada, que seguiam direções diferentes, em determinado momento se integram e passam a ser consideradas prática de uma Hermenêutica geral, que até então era constituída de um conjunto de regras visando uma interpretação com finalidade universal.

Schleiermacher54, filósofo alemão, é considerado o pai da moderna Hermenêutica enquanto disciplina geral e segundo Dilthey, "descobrimos que a finalidade última da Hermenêutica é compreender o autor melhor do que ele próprio se compreendeu, proposição que é a conseqüência necessária da teoria da criação inconsciente".

A Hermenêutica segue historicamente seu desenvolvimento, voltada para questões filosóficas ligadas à razão e à subjetividade do ser humano, às ciências humanas e ciências naturais, estabelecendo a fórmula "experiência-expressãocompreensão" e sendo estes temas, abordados por vários filósofos, como Kant,

\footnotetext{
${ }^{53}$ Aquele que é sectário do gnosticismo, movimento religioso, de caráter sincrético e esotérico, desenvolvido nos primeiros séculos de nossa era à margem do cristianismo institucionalizado, combinando misticismo e especulação filosófica.

${ }^{54}$ Friedrich Schleiermacher (1769-1834) é uma figura chave nesse período. Ele teorizou o chamado círculo hermenêutico do conhecimento nos seus fragmentos de 1805-10 onde podemos ler uma definição desse círculo: "Toda compreensão do individual é condicionada pela compreensão do todo" (Hermeneutik, $2^{\mathrm{a}}$ ed., org. Heinz Kimmerle, Heidelberg, 1974, p.46). Schleiermacher diferenciou dois tipos de abordagem do texto: a interpretação gramatical e a técnica. A primeira ele subdividiu na análise sintagmática (análise interna do discurso) e paradigmática. Nesta última o hermeneuta deveria analisar a relação do discurso com a tradição, com a cultura. Este todo com o qual o discurso individual deve ser confrontado inclui para Schleiermacher também uma teoria dos gêneros literários.
} 
Hegel, Husserl, Heidegger, Ricouer, que dessa forma, contribuíram com a Hermenêutica.

Entretanto, a articulação da Hermenêutica com a dialética, que é a ciência e a arte do diálogo, da pergunta e da controvérsia, se dá apenas mais recentemente na história e conforme Minayo (1996, p.223), foi exposta, inicialmente, por Habermas, "por entender que, do ponto de vista do pensamento, ela faz a síntese dos processos compreensivos e críticos"

Já para Gadamer55, que conforme Minayo (1996, p.220) debateu academicamente com Habermas ${ }^{56}$ sobre a Hermenêutica, esta pode ser entendida como:

a busca de compreensão do sentido que se dá na comunicação entre os seres humanos", onde "a linguagem ocupa um ponto no tempo e no espaço", conceito que é complementado pela autora quando ressalta que ao "ampliar os horizontes da comunicação e da compreensão, nunca escapamos da história, fazemos parte dela e sofremos os preconceitos de nosso tempo.

Minayo (1996), referenciando Stein ${ }^{57}$ sobre o debate entre Habermas e Gadamer, mostra a contribuição e os limites da hermenêutica, alcançando uma proposta de complementaridade com a dialética, factível a partir da própria realidade. Na visão de Stein, apud Minayo (1996, p.226), em ambas há, de forma subjacente, condicionamentos históricos da linguagem, das relações e das práticas, entendendo a não imparcialidade do observador, preservando o aspecto histórico da construção do conhecimento, afirmando que,

É claro que tanto a dialética quanto hermenêutica a não perceberam de maneira explícita o paradigma que elas inauguraram, mas seu modo de proceder como método, dá-lhes indiscutivelmente uma autoridade epistêmica capaz de dar conta de seus pressupostos e produzir níveis de racionalidade cuja legitimação vai-se repondo através do progresso do trabalho teórico.

É importante destacar que, como cita Habermas, enquanto a dialética tem como base o diálogo e a crítica, buscando nos símbolos e na cultura os elemen-

\footnotetext{
${ }^{55}$ Para o filósofo Hans-Georg Gadamer (1900-2002), discípulo de Martin Heidegger (1889-1976) e autor de "Verdade e Método - Esboços de uma Hermenêutica Filosófica", a hermenêutica não seria exatamente uma metodologia das ciências humanas, mas uma tentativa de compreender as ciências humanas. Nesta obra, Gadamer afirma que "a compreensão das coisas e a correta interpretação não se restringe à ciência, mas à experiência humana, principalmente no que se refere ao fenômeno da linguagem como experiência humana de mundo." Cf. Gadamer, Hans-Georg. Verdade e Método. Petrópolis: Vozes, 1997

${ }^{56}$ Jürgen Habermas, filósofo contemporâneo nascido em Düsseldorf em 1929, estudou filosofia em Göttingen, Zürich, e Bonn, prosseguiu como assistente de Teodoro Adorno no Instituto de Pesquisas Sociais em Frankfurt até 1959, tendo ensinado filosofia e sociologia em várias universidades alemãs até aposentar-se em 1994. É considerado o principal representante da segunda geração da Escola de Frankfurt. Cf. Dialética e Hermenêutica. Porto Alegre, Editora LPM, 1987.

${ }^{57}$ Edith Stein, nascida em 1892 em Breslau (na Alemanha, atualmente Wroclaw na Polônia) foi grande estudiosa da fenomenologia, tendo se convertido e ingressado na Ordem das Carmelitas em 1934 com o nome Irmã Teresa Benedita, sendo morta em 9 de agosto de 1942, na câmara de gás de Auschwitz. Foi beatificada no dia 1². de maio de 1987, em Colônia, e canonizada em 1999 pelo papa João Paulo II. Cf. Dialética e Hermenêutica: uma controvérsia sobre o método em filosofia. Porto Alegre, Editora LPM, 1987.
} 
tos contraditórios para realizar a crítica, a hermenêutica busca o contexto, salientando que "a própria linguagem é um instrumento de dominação, necessitando, por este motivo, ser desmistificada e objeto de reflexão: tanto a que é comunicada pelos informantes como a que é utilizada pelos avaliadores" (MINAYO, 2005, p.89). Assim, segundo Minayo (1996, p.227),

Enquanto a hermenêutica penetra no seu tempo e através da compreensão procura atingir o sentido do texto, a crítica dialética se dirige contra seu tempo. Ela enfatiza a diferença, o contraste, o dissenso e a ruptura de sentido. A hermenêutica destaca a mediação, o acordo e a unidade de sentido.

Para a operacionalização do método de pesquisa qualitativa fundamentada na hermenêutica-dialética, Minayo (1996) propõe a reflexão do 'caminho do pensamento' demonstrado por Habermas e sua viabilidade enquanto realização técnica, entendendo ser, esta metodologia, bastante produtiva na medida em que, ao não se fixar em uma determinada técnica específica, possibilita diversas abordagens, diferenciando-se delas e criticando-as ao mesmo tempo, produzindo uma avaliação ao mesmo tempo compreensiva e crítica.

A autora ressalta a necessidade de reunir para a análise, todos os materiais coletados, envolvendo os escritos, as observações realizadas e o contexto das relações sociais do objeto e sujeitos da pesquisa, para então dar início à interpretação, que possui dois níveis, denominados de campo das determinações fundamentais e a fase interpretativa propriamente dita.

O campo das determinações fundamentais, já instituído na fase exploratória da investigação, trata do contexto sócio-histórico do grupo social em análise que, neste estudo, compreende a Educação e a Enfermagem, constituindo o marco teórico fundamental da análise. Neste momento, serão destacados os diversos aspectos que envolvem o contexto sócio-econômico e político dos Enfermeiros e suas participações enquanto atores sociais, além do contexto histórico, de suas representações sociais, bem como de suas concepções e condições de produção, relacionadas à instituição a que se encontram ligados.

O segundo nível de interpretação envolve o encontro com os fatos empíricos, partindo dos fatos relatados em busca das representações sociais manifestadas pelos atores e para tanto, serão buscadas as categorias analíticas, empíricas e organizacionais que sejam capazes de demonstrar as contradições do nível empírico em questão. 
É nesse momento que, segundo Minayo (1996, p.233)

A partir dos dados colhidos e acumulados o investigador se volta para os fundamentos da teoria para uma reflexão sobre os conceitos iniciais, para a colocação em dúvida das idéias evidentes. Assim, ele constrói uma nova aproximação do objeto: o pensamento antigo que é negado, mas não excluído, encontra outros limites e se ilumina na elaboração do presente. O novo contém o antigo incluindo-o numa nova perspectiva.

Do ponto de vista operacional, a fase de interpretação será iniciada pela ordenação dos dados colhidos (entrevistas, documentos, conforme o caso), com a transcrição e releitura do material para sua ordenação classificatória, de acordo com a proposta analítica inicial, seguida da classificação, processo que, sob a "ótica dialética, é um processo que, tendo presente o embasamento teórico dos pressupostos e hipóteses do pesquisador, é feito a partir do material recolhido" (id.ibidem) Para tanto, as atividades englobarão a leitura completa dos textos buscando a constituição de um ou vários corpus de comunicações, no caso de um conjunto não homogêneo de informações, quando será feita uma leitura transversal de cada corpo, utilizando variáveis empíricas e teóricas construídas pela pesquisadora, possibilitando o aprofundamento do conteúdo das mensagens e a busca da identificação dos temas relevantes. 



\section{VI - APRESENTAÇÃO DOS RESULTADOS}

\section{1 - Entrevistas: a análise de conteúdo}

Este capítulo apresenta a discussão dos dados coletados na primeira fase da pesquisa, representada pelas entrevistas realizadas com as docentes do curso de enfermagem escolhido como lócus do estudo e que resultaram na elaboração do relatório síntese, encaminhado, pela pesquisadora, para discussão com o grupo focal, segunda fase deste trabalho.

\subsection{1 - Síntese das entrevistas}

Utilizando a metodologia da análise de conteúdo, conforme preconizado por Minayo (1996), as falas resgatadas nas entrevistas da primeira fase da pesquisa foram analisadas individualmente, o que possibilitou identificar as unidades de significado. A releitura destas unidades de significado permitiu identificar os pontos relevantes ou núcleos de sentido presentes nas comunicações dos sujeitos (Anexos 7 e 8). Posteriormente, estes pontos relevantes foram agrupados, 0 que possibilitou apontar as categorias e subcategorias a serem elaboradas.

A partir do material coletado nas entrevistas, voltadas para a compreensão de quando e como se deu o desenvolvimento de competências para a docência em enfermagem, foi apontada como categoria principal a temporalidade, situada em três momentos fundamentais: o passado, o presente e o futuro.

\footnotetext{
A temporalidade é uma propriedade intrínseca da consciência. O tempo que se encontra na realidade diária é contínuo e finito. Ele existiu antes da pessoa e continuará a existir depois. Isto significa que seus projetos estão condicionados a um tempo e este fato interfere no seu cotidiano, É dentro da estrutura temporal que a vida cotidiana conserva o seu sinal de realidade. (CUNHA; 2004, p.36)
} 
A categoria da temporalidade reflete a posição exposta por Paulo Freire (1983, 1996), ao entender o ser humano como um ser inacabado, em constante transformação, tendo a capacidade de compreender sua realidade, levantando hipóteses sobre o desafio dessa realidade, procurando soluções para sua superação, pois "o homem se identifica em sua própria ação: objetiva o tempo, temporaliza-se, faz-se homem-história”. Além disso, continua o autor,

Todo o amanhã se cria de um ontem, através de um hoje. De modo que o nosso futuro baseia-se no passado e se corporifica no presente. Temos de saber o que fomos e o que somos, para saber o que seremos. (FREIRE, 1983, p.33)

Nas falas analisadas também foram apontadas as subcategorias trajetória profissional, características pessoais e unidade de ensino, como relacionadas à categoria de temporalidade, ligadas ao passado e ao presente, enquanto que para a temporalidade ligada ao futuro, foram apontadas as subcategorias perspectivas e incertezas, conforme apresentado na tabela 6.1.1.a.

Tabela 6.1.1.a - Categorias e subcategorias $-1^{\text {a }}$ fase

\begin{tabular}{cccc}
\hline \multirow{2}{*}{ categorias } & \multicolumn{3}{c}{ temporalidade na capacitação docente } \\
\cline { 2 - 4 } & o passado & o presente & o futuro \\
\hline \multirow{2}{*}{ sub-categorias } & - trajetória profissional & - trajetória profissional & - perspectivas \\
& - características pessoais & - características pessoais & - incertezas \\
& - unidade de ensino & - unidade de ensino & \\
\hline
\end{tabular}

\section{A trajetória profissional}

O aspecto temporalidade na capacitação docente relacionado com o passado e com o presente evidenciou a trajetória profissional como uma subcategoria relevante, por representar a reunião das experiências vivenciadas no passado e acumuladas até o presente, envolvendo não só a formação inicial na graduação, como profissional de enfermagem, mas o conjunto de saberes, técnicas, valores, visões de mundo e outras marcas sociais construídas ao longo da história pessoal e que possibilitaram a formação de suas competências docentes.

Este fato nos remete a Dewey, para quem, a educação é um processo continuado e decorrente da evolução das relações humanas e das sociedades, 
resulta como um todo. Como a existência humana muda a cada instante, fruto das novas situações vivenciadas, para cada mudança, novas superações são necessárias, provocando a construção de novos conhecimentos e competências, compondo a trajetória profissional do docente.

Tardif (2002, p.11), analisando o saber dos professores, ressalta também a relevância da trajetória profissional, afirmando que

[...] o saber não é uma coisa que flutua no espaço: o saber dos professores é o saber deles e está relacionado com a pessoa e a identidade deles, com a sua experiência de vida e com sua história profissional, com as suas relações com os alunos em sala de aula e com os outros atores escolares na escola.

Na mesma direção, Piaget mostrou que as pessoas são as próprias construtoras ativas do conhecimento, constantemente criado e testado conforme as visões de mundo assimiladas e assumidas, de tal forma que os docentes têm importância fundamental na produção dos sentidos estabelecidos, tanto para o docente quanto para o estudante, ao longo do processo educacional.

As falas das entrevistadas revelam que suas competências foram construídas no decorrer das suas trajetórias profissionais e docentes, resultante do processo histórico vivenciado, referindo claramente a imbricação entre o passado e o presente, ao afirmarem que:

A minha capacitação para docente de enfermagem, quando chego para a docência ela tem esse marco no técnico, essa continuidade na faculdade, uma vida profissional em um hospital universitário que me exigia esse tipo de coisa e que para mim, era uma exigência prazerosa, pois eu tinha prazer em fazer isso. (E-03)

Capacitação é um processo em construção, ninguém é docente de um dia para o outro, a gente se forma enfermeira e a enfermeira tem uma conotação essencial, mais técnica, mais voltada para a parte do cuidar. Nós somos seres inacabados, então eu acredito que a gente sempre vai aprender. Então essa capacitação tem ocorrido no transcorrer dos meus anos. (E-07)

Eu comecei na escola sem nenhuma formação pedagógica específica e acho que era fruto da época, as pessoas tinham que ter um domínio técnico, um conhecimento científico, isso que era valorizado para o trabalho do enfermeiro e eu poderia te dizer, até da docência na área; era você ter conhecimento específico daquela área que você ia atuar, porque a idéia era passar o conhecimento, transmitir aquilo que você sabia. Então acho que isso era um predomínio da própria pedagogia da década de 70, 80. (E-08)

Fomos trabalhando, eu fui trabalhando, fui ganhando experiência, amadurecimento, aliada às formações que a gente vai tendo, vai dando uma aprimorada neste fazer. (E-09)

Estas colocações demonstram o reconhecimento, por parte das docentes, da importância de suas trajetórias profissionais na construção das diversas competências docentes. Neste sentido, Tardif (2002, p. 230) refere que o professor 
[...] não é somente alguém que aplica conhecimentos produzidos por outros, não é somente um agente determinado por mecanismos sociais: é um ator no sentido forte do termo, isto é, um sujeito que assume sua prática a partir dos significados que ele mesmo lhe dá, um sujeito que possui conhecimentos e um saber-fazer provenientes de sua própria atividade e a partir dos quais ele a estrutura e orienta.

Com relação à formação profissional para a docência, as falas revelaram que a maioria das docentes não possuía capacitação formal antes de ingressarem nesta área e esta capacitação foi construída de forma empírica, ao longo de suas (então) novas atividades pedagógicas, aliando-se às vivências anteriores da trajetória profissional. Com efeito, entre outras colocações captadas, vemos que:

Não houve uma capacitação formal. Eu acho que vamos experimentando durante a nossa formação algumas aproximações com o ensinar e aprender. [...] Com transmissão de conhecimento por mais conservadora que seja a formação da Enfermagem, ela propicia essa capacitação. Nunca fui uma aluna que foi monitora e nunca tive iniciação científica. (E-01)

Eu não tive capacitação pedagógica, porque eu não fiz licenciatura. Eu entrei aqui e eu nem sabia fazer um planejamento didático. Eu aprendi, aprendendo. [...] Foi de uma maneira completamente empírica que eu aprendi a ser professora. (E-02)

A capacitação docente ocorreu posteriormente, quando eu já era docente [...] porque a gente começou a dar aula sem nenhum preparo, depois é que a gente foi se aprimorando. $(E-04)$

Não tive uma capacitação formal, ela foi se dando pela prática mesmo, com a vivência. A capacitação foi ocorrendo com a própria trajetória profissional, acho que é difícil separar as duas coisas. [...] não me formei para ser professora, na verdade aconteceu, eu não tive uma formação na época, a gente tinha licenciatura, mas eu não fiz.. (E-06)

Quando você começa, você pensa que sabe tudo e com o decorrer do tempo, você também pensa que não sabe nada, então por isso que é um processo. (E-07)

Não existe uma capacitação propriamente dita, antes de eu concluir a graduação fui trabalhar em uma área que não é de interesse de muitas pessoas. (E-09)

Outra dimensão detectada nas falas das docentes, diz respeito ao caráter reprodutivista assumido no início de suas atividades pedagógicas, partindo de modelos de outros profissionais presentes nos momentos de formação e voltado apenas para a transmissão de conteúdos, exatamente na concepção "bancária" da educação ${ }^{58}$, citada por Paulo Freire (1987). As falas demonstram que a maioria das entrevistadas obteve a capacitação após sua inserção no mundo do trabalho

\footnotetext{
${ }^{58}$ Conforme o autor, a educação libertadora implica a superação da contradição educador-educando, resultando na construção conjunta dos conhecimentos, enquanto que "na concepção bancária, que estamos criticando, para a qual a educação é o ato de depositar, de transferir, de transmitir valores e conhecimentos, não se verifica nem se pode verificar esta superação. Pelo contrário, refletindo sobre a sociedade opressora, sendo dimensão da 'cultura do silêncio', a 'educação' 'bancária' mantém e estimula a contradição". (FREIRE, 1987, p.59)
} 
educacional, de forma empírica, na vivência do cotidiano docente, com reforço enfático na competência técnica, destacando-se:

Eu me fiz docente, praticamente repetindo esses modelos, procurando um conhecimento bastante grande da área, que eu queria colocar, era bastante fechada na enfermagem mesmo, e a busca de uma clareza da exposição dos conceitos, de exemplificação, etc. $(E-05)$

Era mesmo uma questão de reprodução de práticas que eu achava interessantes, que à época, essas práticas me impressionavam muito pelo rigor técnico, pela clareza didática de explicar os conceitos. (E-05)

O enfoque educacional foi surgindo durante a residência, você acaba tendo que fazer trabalho, aula e socializar todo esse conteúdo, então foi uma coisa que começou a surgir naturalmente. (E-06)

Eu tenho dois momentos aqui, para comentar com você, o primeiro momento eu achava que eu era uma professora assim... o máximo, porque eu conseguia dar todos os meus conteúdos, achava que sabia tudo e eu me achava o máximo; sempre achei que tinha uma bagagem muito boa, eu gosto de estudar, de ir a congressos, só que depois você tem uma queda, você começa a olhar e percebe que não sabe. (E-07)

A minha inserção na área do ensino não foi uma opção, acho que foi decorrência da minha presença aqui no hospital, no trabalho como enfermeira dos ambulatórios e por esse vínculo que existia da Escola com o Serviço; eu acabei sendo chamada para desenvolver o trabalho mesmo, com os alunos. (E-08)

O caráter reprodutivista que as docentes referem nos momentos iniciais de suas atividades é, segundo Tardif (2002), resultante da vivência escolar dos futuros professores em seu futuro ambiente de trabalho, o que os leva, antes mesmo de começarem a ensinar, já conhecerem de muitas formas, como é o ensino em decorrência de sua vida escolar anterior.

A trajetória de vida faz com que o professor trate o conhecimento de forma similar com a que recebeu e da mesma forma com que vivenciou suas experiências escolares. Esta situação decorre da temporalidade da formação do indivíduo, que segundo o autor, se aplica não só à esfera profissional e escolar, mas também diretamente à sua carreira,

[...] carreira essa compreendida como um processo temporal marcado pela construção do saber profissional. Esse tema da carreira profissional, por sua vez, incide sobre temas conexos como a socialização profissional, a consolidação da experiência de trabalho inicial, as fases de transformação, de continuidade e ruptura que marcam a trajetória profissional, as inúmeras mudanças (de classe, de escola, de nível de ensino, de bairro, etc.) que ocorrem também no decorrer da carreira profissional e, finalmente, toda a questão da identidade e da subjetividade dos professores, que se tornam o que são de tanto fazer o que sabem. (idem, p.20, grifos nossos)

O reconhecimento da incompletude de suas formações profissionais para assumir a docência, fez com que a totalidade das entrevistadas buscasse novos 
conhecimentos específicos, observando-se que a maioria buscou a capacitação

na área da Educação, referindo-se a esta decisão de forma clara e objetiva:

A PUC oferecia cursos, porque era época de discussão do projeto pedagógico da universidade, a gente foi fazer o curso de capacitação pedagógica e eu entrei aqui dando aula em educação e saúde; aí que eu fui me aproximar desse processo de como aprender e como ensinar e de algumas práticas pedagógicas. (E-02)

Estava começando um curso de mestrado em educação e eu entendi que teria que fazer em educação, e pensei: como eu vou para área de docência, eu tinha licenciatura que fiz durante a faculdade, mas era insuficiente, fui fazer minha inscrição; ao mesmo tempo em que eu estava sendo selecionada aqui para escola, eu estava sendo selecionada no curso de mestrado, eu entendi que ele iria me ajudar muito, como me ajudou, ampliou muito minha visão, de ver um contexto porque a área de concentração é de ensino superior. (E-03)

Eu fiz o meu mestrado na área de educação, fui ver a função educativa do enfermeiro, com muitas leituras do aprendizado do adulto, da própria pedagogia e leitura de literatura para a própria tese, fui chegando, fui me enxergando, fui me encontrando e fui me capacitando através disso. (E-06)

Embora não existisse uma formação formal porque nós não éramos pedagogos, educadores na formação básica, nós tivemos a oportunidade de fazer essa discussão, a Universidade, a escola trazia uma série de palestristas, pessoas de renome como Terezinha Rios, Paulo Freire, então a gente teve contato com pessoas de expressão no cenário nacional e até internacional na área de Educação. Isso contribuiu muito, isso foi dando um embasamento da área da Educação que a gente não tinha. (E-08)

A trajetória profissional, conforme apontado pelas professoras, sofreu influência igualmente de outros fatores, principalmente os relacionados com o desenvolvimento da autonomia intelectual dos docentes e dos estudantes, com vistas à construção de conhecimentos e transformação da realidade. Como elementos facilitadores relacionados ao desenvolvimento de suas competências docentes, no tocante ao presente e também influenciados pelo passado, foram citados as vivências acadêmicas oportunizadas, a experimentação, a auto-avaliação, as atividades profissionais-assistenciais e o caráter coletivo das competências. A capacitação e a educação continuada foram consideradas os alicerces para o processo de ensino-aprendizagem.

Participação em reuniões de escolas de enfermagem, porque é aí que se discute a questão de ensino de enfermagem, eu vejo isso como uma capacitação, uma questão importante para continuidade ou para como minha capacitação ocorre hoje a própria questão de estar na docência. (E-03)

Acho que essa competência de uma transposição didática daquilo que permita, daquilo que eu sonho e que é muito amplo e é fluído para eles, de uma forma que eles sintam segurança e vão rompendo no limite deles aquilo que sei lá em quantos anos de profissão eu consegui fazer; eu acho que tenho que dosar isso. Acho que é essa competência que eu estou tentando. Como que estou fazendo? Experimentando. (E-05) 
A gente já tem uma competência mais tecnológica, porque é um linguajar diferente, os jovens de hoje vem com outras exigências com outra experiência, de estar usando essa experiência deles no momento atual, o acesso à Internet, a informação tão rápida, qual que é a qualidade dessa informação? Como a gente pode usar isso, em beneficio daquele conteúdo que a gente está ministrando, então, eu acho que teve essa competência que tem hoje e que não havia antigamente, do acompanhar essa tecnologia e o desafio é como a gente atrela tudo isso, lembrando que não é só a competência técnica, tem a crítica e como fazer isso. (E-06)

Para ajudar essa capacitação, com certeza alguns cursos têm ajudado, que eu colocaria para você, como aprimoramento, e esse seria através de um curso de especialização que o de metodologia do ensino superior que foi ministrado pela universidade, para todos os docentes novos, dando algumas dicas de como deveríamos utilizar algumas estratégias em sala de aula, que era isso que nos deixava mais assustadas no início. $(E-07)$

A minha capacitação nos dias de hoje, dando continuidade na capacitação, na formação acadêmica foi o mestrado na área de educação. [...] Fico pensando nas competências para ser professor, acho que a gente tem que estar atualizada, tem que estar antenada com tudo que está acontecendo no mundo, tem que estar informado sobre tudo que está acontecendo na profissão. (E-08)

Também se destacam nas falas, como aspecto facilitador para a construção das competências docentes ao longo da trajetória profissional, as relações interpessoais com os estudantes e professores, na medida em que os conteúdos eminentemente técnicos, inicialmente preponderantes sobre a ação pedagógica, cederam espaço para a conformação de uma educação dialógica, na qual o aluno é o principal sujeito da aprendizagem, procurando se distanciar de uma pedagogia passiva, pouco criativa e acrítica. Neste sentido, assim elas referem:

Eu considero que as competências desenvolvidas foram: a comunicação, a percepção de algumas variáveis que fazem parte do processo de ensinar e aprender tais como histórias de vida, exemplos vividos profissionalmente, situações vivenciadas em estágios com alunos e levadas para a sala de aula para outros alunos, compartilhamento de emoções, lições de vida, alteração dos julgamentos pré-estabelecidos e que diante de uma situação que você jurava que agiria de tal forma, você se depara agindo de outra e isso é bom, pode se rever, alterar coisas e modos de pensar. (E-01)

Naquele momento desenvolvi competências técnico-científicas relativas à área de enfermagem em aspectos não só assistenciais, mas gerenciais e educativos, sendo que estes últimos certamente promoveram a condição para na seqüência, desenvolver junto à equipe de enfermagem questões educativas, bem como a presença de alunos de graduação da área da saúde também estimularam o colocar em prática este aspecto educacional. (E-03)

Eu vim com uma competência no início e acho que a gente foi aprendendo, foi crescendo e foi vendo essa condição um pouco mais humanista, de tentar entender o aluno, de compreender esse nosso aluno trabalhador, de ver onde a gente pode motivar, ao invés de cobrar. (E-06)

Aquele conteúdo que eu achava maravilhoso, tudo sobre fisiopatologia, o que você me perguntasse eu sabia, mas eu vejo que não é nada, comparada com o vínculo que você faz com o aluno no ensino/aprendizagem. Porque é esse cuidar, é esse vínculo que 
transforma o enfermeiro não em docente, mas que dá brechas, alguns focos para ele começar a construir a sua identidade como docente. (E-07)

É um papel de muita responsabilidade que a gente tem e para isso valer, tem que discutir com os pares, se posicionar, fazer a crítica do momento atual, daquilo que está ocorrendo, isso dá um diferencial importante para uma educação que você não pretende que seja só uma repetição, uma transmissão do conhecimento; que seja mesmo numa linha de promover uma autonomia intelectual para o aluno, de contribuir para que o aluno seja realmente produtor de seus conhecimentos e seja alguém que vai fazer a transformação dessa sociedade, alguém que vai fazer a diferença, inserido naquele trabalho, naquela comunidade, acho isso fundamental. (E-08)

A análise das falas aponta ainda para aspectos facilitadores e dificultadores referentes à trajetória profissional, observados no passado e que representaram pontos relevantes para a formação das competências docentes. Assim, como aspectos facilitadores, referem: as experiências e vivências; a participação de monitorias e em projetos de iniciação científica, bem como de estágios curriculares; a capacitação formal em área afim; experiências na assistência; compartilhamento com grupo de alunos.

Ainda como aspectos facilitadores relacionados com a trajetória profissional, encontramos o vínculo entre a unidade de ensino com o serviço de enfermagem, possibilitando maior contato entre os docentes de outras áreas no cotidiano profissional, bem como a realização de capacitações formais na área pedagógica e experiências de vida, conforme pode ser constatado nas falas seguintes:

Como aluna, eu tive em alguns estágios a possibilidade de trabalhar com temas de educação e saúde, principalmente na área da saúde coletiva que sempre foi o meu eixo maior, o meu interesse maior durante a formação, então trabalho voluntário em comunidade, em escola porque eu gostava de estar junto da população carente e mais os estágios que também ajudavam, então não houve uma capacitação formal houve essa aproximação dessa forma, muito incipiente, mas muito significativa. (E-01)

Na modalidade de estágio, eu tinha um maior preparo, você tem que estudar mais, as dificuldades que se apresentam essa relação professor/aluno no cotidiano, ela envolve algumas coisas que você deve aprender, mas eu tinha mais facilidade, talvez alguma dificuldade na hora de fazer avaliação, de eleger critérios subjetivos. (E-02)

Essas capacitações que têm sido de metodologia do ensino superior e o próprio mestrado, que te dá uma bagagem para entrar como educador, isso têm sido momentos impares que contribuíram no meu crescimento como docente. (E-07)

Por outro lado, entrevistadas reconhecem que certos aspectos na trajetória profissional foram dificultadores com relação à construção de competências, exemplificam essas dificuldades como a falta de conhecimentos específicos na área pedagógica, o afastamento da área de formação, o despreparo para a realização de planejamento e a dificuldade na eleição de critérios subjetivos para a 
prática de avaliações. Consideram isto decorrente das modificações do ensino positivista como da sua época de formação para a conformação atual do ensino, conforme pode ser constatado nas falas seguintes:

A minha escola era muito retrógrada, mas eu acho que isso é um desafio que ficou aí para nós. (E-02)

Fiz isso no mestrado, na própria enfermagem; foi um caminho interessante, mas insuficiente. (E-05)

Eu vim de uma escola muito positivista. (E-06)

Acabei fazendo a trajetória específica da minha área que era o doutorado na área da saúde coletiva e eu senti que me distanciei um pouco dela enquanto espaço mais formal, de estudos, de aprofundamento, porque eu fiquei por um tempo ligada na área de educação. (E-08)

As falas coletadas, referendam Cunha (2004, p.31), para quem a concepção de ensino e as práticas realizadas pelos professores, devem se voltar para concepções mais amplas do fenômeno ensino/aprendizagem, assumindo, os educadores, que "aprender não é permanecer em atitude contemplativa ou alienada com relação aos dados culturais da sociedade e do outro, o educando, mas sim estar ativamente envolvido na interpretação e produção destes dados", configurando um ensino efetivo e dialogado.

Isto representa, conforme Paulo Freire (1987, p.83), assumir uma educação libertadora e dialógica, na qual, o diálogo, "esse encontro dos homens, mediatizados pelo mundo, para pronunciá-lo, não se esgota na relação educadoreducando. Somente o diálogo, que implica um pensar crítico, é capaz, também, de gerá-lo, e sem ele não há comunicação e sem esta, não há a verdadeira educação".

\section{As características pessoais}

A subcategoria representada pelas características pessoais dos docentes na construção das competências, apontada na análise das falas, igualmente relaciona o passado ao presente, destacando os aspectos motivacionais e relacionais como preponderantes nessa construção.

Entendendo o ser humano como um ser inacabado e em constante transformação, Paulo Freire $(1983,1996)$ coloca que, tendo a capacidade de compreender sua realidade e levantar hipóteses sobre o desafio dessa realidade, procu- 
rando soluções para sua superação, "o homem se identifica em sua própria ação: objetiva o tempo, temporaliza-se, faz-se homem-história”.

Morin (1993, p.49), ressaltando a complexidade do ser humano e de suas características individuais, afirma

\begin{abstract}
Cada ser humano é um cosmos, cada indivíduo é um bulício de personalidades virtuais, cada psiquismo segrega uma proliferação de fantasmas, sonhos e idéias. Cada um vive, do nascimento à morte, uma tragédia insondável, marcada por gritos de sofrimento, de gozo, de lágrimas, abatimentos, grandeza e miséria. Cada um traz consigo tesouros, carências, falhas, abismos. Cada um transporta consigo a possibilidade do amor e da devoção, do ódio e do ressentimento, da vingança e do perdão. Reconhecer isto é reconhecer também a identidade humana. O princípio de identidade humana é unitas multiplex, a unidade múltipla, tanto do ponto de vista biológico, como cultural e individual.
\end{abstract}

Com relação à construção das competências docentes, as entrevistadas revelam que as características pessoais representaram elementos relevantes no decorrer de suas atividades profissionais e docentes, principalmente para 0 ingresso na carreira docente, indicando os aspectos relativos à vocação, ao interesse e à disposição para o aprendizado, como determinantes no passado, permanecendo impactando igualmente no presente.

A fase inicial de uma carreira profissional representa um período contraditório, obrigando o indivíduo, muitas vezes, a reflexões sobre suas aspirações, capacidades, vocações e sonhos. Com efeito, se por um lado, o início da carreira corresponde a um espaço na vida do profissional que traz o "reconhecimento do valor de sua participação ativa no mercado de trabalho, por outro lado, as estruturas ocupacionais raramente correspondem à identidade vocacional definida nos bancos de escola, ou através das diferentes atividades sócio-culturais, ou modelada pelas expectativas familiares" (CAVACO, 1995, p.162).

Assim, é no jogo de procura de conciliação, entre aspirações e projectos e as estruturas profissionais, que o jovem professor tem de procurar o seu próprio equilíbrio dinâmico, reajustar, mantendo o sonho que dá sentido aos seus esforços. (id.ibid.)

Nesta direção, as professoras relatam que a "migração", da área assistencial ou técnica para a acadêmica, ocorreu em decorrência de características pessoais, principalmente relacionadas com o aspecto vocacional, de interesse pessoal e de disposição para o aprendizado, afirmando que:

Eu tenho uma certa facilidade, eu acho, não dá para ignorar, uma certa facilidade de comunicação, de falar. (E-01) 
Eu vim da USP Ribeirão para a PUC. Lá, já notaram que eu tinha uma vocação para a docência. Eu comprei livros de didática, [...] mas muito eu já tinha de vocação. Eu seria professora em qualquer profissão que eu tivesse. (E-02)

Já aí me interessei por essa questão de poder compartilhar aquilo que já tinha passado, me capacitado de alguma forma; para mim este é um ponto principal que me trouxe possivelmente agora, estar na docência em enfermagem. (E-03)

Eu sempre gostei de ensinar na época de estudante, eu vivia ensinando alguém, sendo professora. (E-05)

Eu vim com uma competência no início e acho que a gente foi aprendendo, foi crescendo e foi vendo essa condição um pouco mais humanista, de tentar entender o aluno, de compreender esse nosso aluno trabalhador, de ver onde a gente pode motivar, ao invés de cobrar. (E-06)

Outra coisa que também considero importante que faz com que você se capacite, é o autoconhecimento e a autonomia intelectual. (E-07)

Além da vocação, entendida como sendo a disposição natural e espontânea que orienta uma pessoa no sentido de uma atividade, uma função ou profissão, outras características pessoais foram apontadas pelas professoras, como relacionadas aos aspectos do autoconhecimento e da autonomia intelectual como relevantes para a busca contínua do desenvolvimento docente, referindo também outros aspectos ligados à esfera individual, envolvendo:

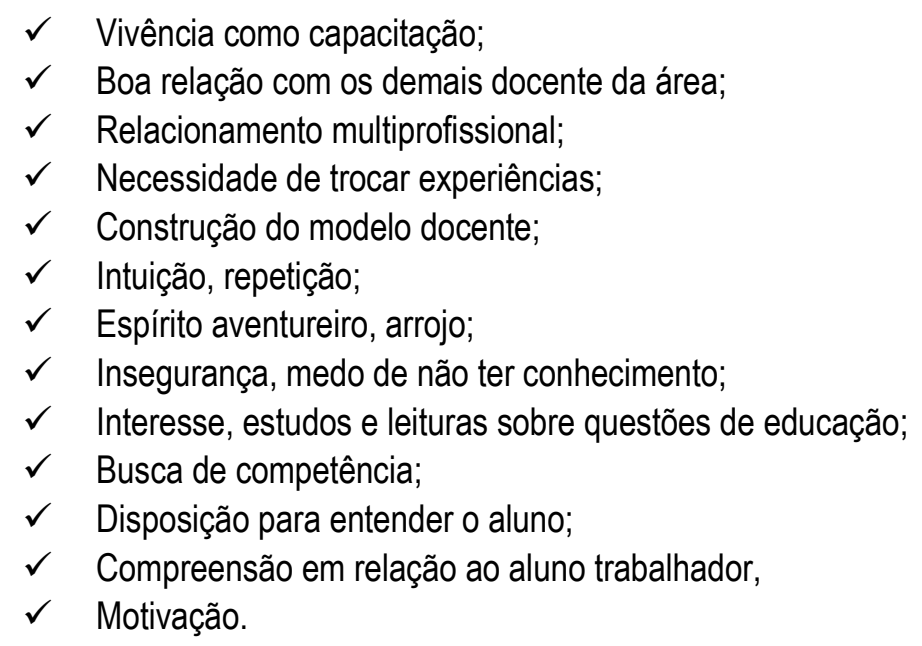

Outras falas demonstram que a temporalidade entre o passado e o presente foi apreendida pelas entrevistadas, na medida em que indicam que os fatos, as vivências, as experiências e competências construídas ao longo do tempo, repercutiram claramente no presente, possibilitando as transformações dos pensamentos, das visões de mundo, das atitudes, e principalmente, no caso da docência em enfermagem, da visão ética no cuidado.

Acho que a competência que estou desenvolvendo seja a de acreditar que outro mundo é possível. Eu não sei, acho que estou vivendo um momento ímpar da docência e não 
sei como ela deva ser, estou gostando como ela está sendo agora, sem muita preocupação com a minha performance, sem muita preocupação de que forma o aluno vai entender a minha figura ali, sem muita preocupação também se eu sou uma autoridade ou não, mas eu estou querendo estabelecer pela docência uma relação com conhecimento que necessariamente traga algo que eu acho essencial que é a ética no cuidado, isso para mim é o fundamental. (E-01)

Competência... você acha que paciência é competência? Acho que paciência, o exercício da paciência, o exercício da alteridade, o exercício cada vez maior da paciência porque lidar com o jovem, para mim, é cada vez mais difícil; eu não tenho dificuldade de geração, não me sinto uma pessoa velha criticando a nova geração, até porque um dia eu fui a nova geração que estava lá numa escola completamente retrógrada. (E-02)

Estou num momento da minha vida que é pessoal também e tem a ver profissionalmente não se separa essas coisas, eu estou em uma fase muito especial sinto que é do amadurecimento, é um marco, tem uma coisa diferente. Inicialmente no campo profissional o que eu tenho feito aqui na escola que é o meu lugar maior de trabalho, sinto que na minha capacitação a continuidade se deu e vai continuar se dando enquanto tiverem essas pessoas no grupo ou em capacitação ou com essa vontade e desejo de também continuar se atualizando e vendo que isso é de suma importância para a docência, mas paralelamente eu tenho um momento que é um momento de querer mesmo ver nessas pessoas, a continuidade, eu não estou me achando velha e nem amadureci$d a$, mas precisando fazer algumas outras coisas. (E-03)

Minha capacitação hoje ocorre através do empenho pessoal, através de participação em cursos na minha área, participação em congressos, através de leituras e através dos cursos que a própria PUC oferece. Eu tenho dúvidas e eu não tenho muito com quem trocar. (E-04)

Eu percebo que eu tenho uma outra fase que é a fase de uma vontade de não ter regras. Aí passo a crer uma prática que é dialogada, respeitosa, ética, e que algumas vezes me leva ao limite quase de ficar frouxo, sem limites, porque eu quero apostar que os alunos aprenderão, então, eu não preciso de recursos mais autoritários, mais diretivos. Hoje o meu desejo seria manter essa linha que eu acredito, trabalhar muito na base dos valores, da ética, do compromisso, de uma aplicação eu diria mesmo edificante dos conhecimentos para gerar atitudes, profissionais mais responsáveis, mais posicionados, mais comprometidos e a possibilidade de uma organização didático-pedagógica que permita que a gente faça isso e que tanto a eles quanto a mim dê a segurança de que alguma coisa aconteceu. (E-05)

Que difícil! Porque é o antes, o agora e o depois! Fica um emaranhado porque você vai mudando e você não consegue mais saber como é que você era antes, fica diferente esse olhar porque parece que você já era assim. (E-06)

Tenho uma formação básica em enfermagem, mas a minha profissão, eu sou docente, eternamente trabalhei assim. (E-09)

As falas captadas mostram, que as características pessoais estão presentes como aspectos facilitadores na formação das competências docentes, e não foram apontadas como aspectos dificultadores. Entre os aspectos facilitadores foram citadas a crença em um mundo possível da transformação social e a dimensão ética do cuidado como eixos norteadores para o desenvolvimento das competências. 
A dimensão ética ${ }^{59}$ está relacionada à busca de justificativas para as regras propostas pela moral e pelo direito, identificando o que é "bom ou mau", "correto ou incorreto", justo ou "injusto", "adequado ou inadequado", e não se estabelece por regras. Para Tardif (2002, p. 145), em reflexão sobre a docência, coloca claramente a ética como categoria primordial, referindo que

[...] os ofícios ou profissões de relações humanas apontam para questões de poder, de maneira intrínseca, mas também para problemas de valor, pois seus próprios objetos são seres humanos capazes de emitir juízos de valor e possuem, como seres humanos, direitos e privilégios. Nesse sentido, a dimensão ética não é um elemento periférico nas ocupações e profissões de relações humanas, mas está no próprio cerne do trabalho.

Esta dimensão ética pode ser compreendida a partir do entendimento que o professor interage individualmente com grupos formados por estudantes heterogêneos, tendo de atingir, ao mesmo tempo, os objetivos definidos pela escola, organização de massa e baseada em padrões gerais, ou seja, tem de agir em grupo para atingir os indivíduos que o compõe. Por outro lado, há a questão ética do domínio do saber, já que o professor domina-o, e os alunos, não. Para resolver este problema de natureza evidentemente ética, o docente deve interagir com o grupo e permitir-lhe o acesso a seus conhecimentos, possibilitando a aprendizagem, com eqüidade.

O conceito de transformação captado nas falas das entrevistadas, difere do seu uso corrente, de equivalência a mudança, alteração ou modificação, aproximando-se de uma perspectiva dialética, segundo a qual transformar significa passar de uma forma para outra, assumindo uma nova forma, feição ou caráter a alguma coisa, tornando-a diferente do que era no estado anterior, transfigurando-a, tal como exposto por Vasconcelos (2001, p.43), que entende

[...] transformar com um sentido mais radical, que tem como expectativa a superação histórica, uma mudança profunda do conjunto de relações do homem com a natureza, com o outro e com ele mesmo. Contrapõe-se à idéia de manutenção (cristalização, perpetuação do mesmo), ou de reforma (mudanças superficiais, maquiagem). Tendo em mente que a situação predominante no mundo de hoje é a exclusão, para nós, transformação terá sempre uma valência positiva, de libertação.

\footnotetext{
${ }^{59}$ Segundo o Dicionário Aurélio, ética é "o estudo dos juízos de apreciação que se referem à conduta humana susceptível de qualificação do ponto de vista do bem e do mal, seja relativamente à determinada sociedade, seja de modo absoluto".Conforme a doutrina moral do filósofo alemão Kant (1724-1802) e de seus seguidores, ética é caracterizada pela formulação de leis e imperativos morais que se fundamentam em formas universais e apriorísticas da razão, sem ligação imediata com a experiência concreta ou com os valores efetivamente cultivados nas sociedades ou na história. Pode ser entendida também como uma teoria (em geral de natureza filosófico-religiosa) segundo a qual os imperativos éticos promanam de uma origem natural ou divina que transcende a livre autodeterminação do ser humano, incapaz de estabelecer com suas próprias forças um conjunto de regras e leis morais que atinja a perfeição necessária.
} 
Outras características pessoais relacionadas com aspectos facilitadores, observados no passado e que representaram pontos relevantes para a formação das competências docentes foram:

$>$ melhoria nas relações interpessoais com os estudantes, a partir da adoção de uma prática docente dialogada, respeitosa e ética;

> o desenvolvimento de outras competências, resultante de interesse e empenho pessoal e repercutindo na continuidade da construção de conhecimentos, por meio de novas leituras e estudos;

$>$ assumpção da intencionalidade da transformação;

$>$ auto-avaliação;

$>$ interesse e desejo de coisas novas

\title{
A unidade de ensino
}

A unidade de ensino, por representar o lócus privilegiado da educação, é assumida pelas docentes entrevistadas como uma subcategoria destacada, na medida em que a maior parte das ações efetivamente pedagógicas ocorre no seu interior. Na visão de Cunha (2004, p.24),

\begin{abstract}
a escola é uma instituição contextualizada, isto é, sua realidade, seus valores, sua configuração variam segundo as condições histórico-sociais que a envolvem. Há toda uma confluência de fatores que determinam seu perfil e suas manifestações. O professor, com relação à escola é, ao mesmo tempo, determinante e determinado. Assim como seu modo de agir e de ser, recebem influências do ambiente escolar, também influencia o mesmo ambiente.
\end{abstract}

Nesta direção, reconhecendo a formação profissional do docente como fruto de uma construção histórica, necessariamente imbricada com a unidade de ensino, Tardif (2002, p. 14) afirma que

o saber dos professores não é um conjunto de conteúdos cognitivos definidos de uma vez por todas, mas ao contrário, um processo em construção ao longo de uma carreira profissional na qual o professor aprende progressivamente a dominar o seu ambiente de trabalho, ao mesmo tempo em que se insere nele e o interioriza por meio de regras de ação que se tornam parte de sua "consciência prática".

As professoras relatam que a unidade de ensino possuía, no passado, características diferentes com relação ao presente, em função das condições sócio- 
políticas, econômicas e culturais, de cada época. Com relação ao passado, referem o caráter positivista e eminentemente técnico, afirmando que

Não havia quem nos ensinasse aqui dentro. A minha escola era muito retrógrada, mas eu acho que isso é um desafio que ficou aí para nós. (E-02)

Na minha escola existia uma apostila e é verdade eu não estou mentindo, todo o ensino de enfermagem fundamental era estudo dirigido; então se fazia aquela apostila e era para uma determinada aula. Tinha uma apostila que era para ditar como se portar, ou seja, a cor da unha a cor do esmalte, a cor da calcinha, a largura das pernas das calças, o comprimento do avental, a barra da calça para o sapato, e isso ficou muito pesado para mim, foi uma vivência muito pesada; eu tinha vontade de sair da escola diariamente. (E-02)

Eu já trabalhava na faculdade e depois de uns três anos, a PUC começou a oferecer alguns cursos de aprimoramento aos docentes, nos quais eles ensinavam os professores a elaborar, planejar, elaborar provas, desenvolver o senso de observação, se relacionar em equipe, então eu lembro que fiz vários desses cursos que eram de curta duração, mas foram muito importantes e me lembro que foram ministrados por docentes da educação da própria PUC. (E-04)

Eu vim de uma escola muito positivista e minha vinda para a docência acabou sendo ao acaso, acabei saindo do hospital e vim para a escola pedir uma orientação profissional. (E-06)

Embora não existisse uma formação formal porque nós não éramos pedagogos, educadores na formação básica, nós tivemos a oportunidade de fazer essa discussão, a Universidade, a escola trazia uma série de palestristas, pessoas de renome Terezinha Rios, Paulo Freire, então a gente teve contato com pessoas de expressão no cenário nacional e até internacional na área de Educação. Isso contribuiu muito, isso foi dando um embasamento da área da Educação que a gente não tinha. (E-08)

Nós fizemos todos os cursos que foram ministrados, com pessoas que eram referência na área da educação, tudo investindo na capacitação. Estes cursos contribuíram muito para atividade docente. (E-09)

Com relação às características organizacionais das unidades de ensino,

Tardif (2002, p. 22) mostra que

A organização escolar foi idealizada a partir das organizações industriais (tratamento em massa e em série, divisão extrema do trabalho, especialização, etc.) e o ensino, como uma forma de trabalho técnico susceptível de ser racionalizado por meio de abordagens técnico-industriais típicas, como o behaviorismo clássico, por exemplo, mas também, atualmente, através de concepções tecnológicas da comunicação que servem de suporte às novas tecnologias de informação.

Por outro lado, as professoras demonstraram em suas falas que a instituição representou em muitos momentos, componente facilitador para o processo de construção das competências docentes, processo este que permanece na atualidade, possibilitando a melhoria das relações interpessoais e a transposição didática, afirmando que: 
Sem dúvida nenhuma o conhecimento, o estudo, o meu aprimoramento pessoal e profissional de certa forma foi dirigindo para um determinado tema, me aprofundando numa determinada área de conhecimento. É um elemento facilitador, porque eu posso transitar nessa área com muito mais facilidade sem dúvida alguma. (E-01)

Acho que devemos repensar muita coisa... competências que tem se discutido tanto, nós ainda estamos muito vinculado à uma competência muito técnica que acho que tem toda sua importância não quero subestimar isso, mas tem outras questões a serem trabalhadas e principalmente essa coisa mesmo da articulação que o aluno tem que fazer com as questões, então eu acho que fica muito esvaziado eu acho que até temos uma proposta bem definida, importante mesmo para a formação, mas temos conseguido pouco alcançar isso (E-03).

Eu já trabalhava na faculdade e depois de uns três anos, a PUC começou a oferecer alguns cursos de aprimoramento aos docentes, nos quais eles ensinavam os professores a elaborar, planejar, elaborar provas, desenvolver o senso de observação, se relacionar em equipe, então eu lembro que fiz vários desses cursos que eram de curta duração, mas foram muito importantes e me lembro que foram ministrados por docentes da educação da própria PUC. A gente vê que precisa crescer mais e a gente cresce todo dia. (E-04)

Estou numa fase, no momento da curvatura da vara: voltando, mas voltando diferente, para um lugar que eu também não quero habitar do mesmo jeito. (E-05)

Acho que essa competência, que estou desenvolvendo é muito voltada para essa outra visão não tanto positivista, mas, de construir, de dividir as responsabilidades, de trabaIhar com ele, a gente vai amadurecendo: o quê que eu quero para essa vida, para esse profissional, que sensibilidade eu quero que ele tenha, como é que eu posso querer que ele seja um profissional dessa forma se eu não for assim com ele! Tentar mostrar também essa outra visão. Acho que seria uma visão qualitativa, integral, acho que uma visão holística. (E-06)

Para ajudar essa capacitação, com certeza alguns cursos têm ajudado, que eu colocaria para você como aprimoramento e esse, seria através de um curso de especialização que o de metodologia do ensino superior que foi ministrado pela universidade, para todos os docentes novos, dando algumas dicas de como deveríamos utilizar algumas estratégias em sala de aula, que era isso que nos deixava mais assustadas no início. Estou em um momento de achar que estou ainda neste processo de ensino / aprendizagem. $(E-07)$

É um papel de muita responsabilidade que a gente tem e para isso valer, tem que discutir com os pares, se posicionar, fazer a crítica do momento atual, daquilo que está ocorrendo, isso dá um diferencial importante para uma educação que você não pretende que seja só uma repetição, uma transmissão do conhecimento; que seja mesmo numa linha de promover uma autonomia intelectual para o aluno, de contribuir para que o aluno seja realmente produtor de seus conhecimentos e seja alguém que vai fazer a transformação dessa sociedade, alguém que vai fazer a diferença, inserido naquele trabalho, naquela comunidade, acho isso fundamental. (E-08)

A unidade de ensino, segundo as falas das entrevistadas apresentou e, apresenta ainda, situações e conformações dificultadoras para a construção das competências docentes, como o número excessivo de alunos, a falta de tempo 
docente para dedicação a estudos, dificuldades para a participação em eventos externos, além da prontidão do ingressante, afirmando:

Tem uma coisa muito desanimadora que você não pode se deixar levar: outro dia na classe uma aluna não sabia o que era diletante; parece que eles não têm a curiosidade que a gente tem, ou que deveriam ter. (E-02)

Hoje até priorizo em relação ao próprio congresso, até porque às vezes não é possibilitado você sair, ou com as reposições que tem que fazer ou economicamente às vezes não é tão possivel. (E-03)

Gostaria muito que na faculdade tivesse um órgão de apoio nesse sentido, um facilitador para isso, que dissesse; isso está adequado, isso esta errado, se seu objetivo está batendo com a introdução, não está batendo. O nosso tempo é muito restrito e a gente quer ler quer produzir e como não tem tempo isto frustra muito o professor, porque se ele não está na carreira docente, se ele não procurar por si mesmo produzir, ele vai ficando a parte. (E-04)

Tem outra questão que me preocupa, que é a forma como o jovem chega na universidade e como hoje a sociedade está valorizando o jovem com acesso ao mundo da informática, eu vejo que a gente compete um pouco a atenção dele, aquelas aulas por mais que você queira avançar e tudo mais, a competição com o mundo da Internet, as informações, a questão da agilidade de conhecimento e tudo, é difícil. (E-08)

A gente tem poucos professores em carreira, poucos professores fazendo pesquisa. (E08)

O professor da sala de aula, por mais eu sei o que seria bom para ele, não me sinto competente para desenvolver bem isso. Me sinto perdendo do que eu sei que consigo fazer num pequeno grupo, que é ter objetivos, que eu acho que são concernentes a uma leitura do papel do educador hoje e que consigo fazer bem isso, no campo de estágio, num grupo de 10, 15 alunos ou até 20, mas, com 80 eu não tenho esta competência. $(E-09)$

\section{Com relação às competências desenvolvidas ao longo do processo viven-}

ciado, as entrevistadas citam a autonomia intelectual, a auto-avaliação, a habilidade de compartilhar os saberes com o outro, a competência ética e relacional, entre outras, assim referindo:

O espaço da docência trás uma autonomia por mais que a instituição possa fazer amarras, quando você fecha a porta da sala de aula, ali não tem ninguém que roube as suas idéias, não tem ninguém que roube os seus princípios, ninguém faz isso nem é capaz de controlar, esse é o maior prazer que tenho de saber que não fui totalmente capturada. $(E-01)$

O campo de estágio suscita que você procure adquirir competências para poder ensinar os alunos; é discussão de caso, problemas que aparece para você, complexidade da realidade, do cotidiano, isso te instiga demais. (E-02)

Um ponto eu atribuo com muita importância. A importância de ter no grupo que você trabalha mais de perto que é a disciplina de administração de gerenciamento..... capacitação, então me vejo trabalhando com três pessoas, uma no mestrado e duas no doutorado, então é assim, a todo momento estou recebendo; li esse artigo achei interessante, teve uma aula, as pessoas querendo compartilhar e eu fico pensando que preciso também ler isso, preciso me aproximar e sempre com a sensação que estou ficando atra- 
sada e acho isso tudo estimulante, é na verdade o que mobiliza internamente, que te motiva a estar buscando. (E-03)

Acho que para o professor está mais dificil dele encontrar respaldo para essas práticas e o aluno, tem momentos que se surpreende com esse acolhimento, com essa disposição, com essa entrega que é a competência. A competência, sabe o que é? É entrega mesmo, está posta no outro, está no desejo que o outro e'... como posso te dizer... te faça de alguma forma, permanecer, quando tudo já passou. (E-05)

A gente já tem uma competência mais tecnológica, porque é um linguajar diferente, os jovens de hoje vem com outras exigências com outra experiência, de estar usando essa experiência deles no momento atual, o acesso à Internet, a informação tão rápida, qual que é a qualidade dessa informação? Como a gente pode usar isso, em beneficio daquele conteúdo que a gente está ministrando, então, eu acho que teve essa competência que tem hoje e que não havia antigamente, do acompanhar essa tecnologia e o desafio é como a gente atrela tudo isso, lembrando que não é só a competência técnica, tem a crítica e como fazer isso. (E-06)

A capacitação ela vem sempre e sempre vai se processar com o outro. Não é uma coisa solitária, eu acho que essa capacitação é uma autonomia tua, mas sempre vinculada a um grupo, uma coletividade, ao aluno, ao grupo de docentes, a própria ideologia que você tem, de pensar que você quer realmente que se processe uma capacitação de ensino / aprendizagem que você queira realmente uma coisa melhor para o aluno. (E-07)

A minha capacitação nos dias de hoje, dando continuidade na capacitação, na formação acadêmica foi o mestrado na área de educação. Fico pensando nas competências para ser professor, acho que a gente tem que estar atualizada, tem que estar antenada com tudo que está acontecendo no mundo, tem que estar informado sobre tudo que está acontecendo na profissão. (E-08)

Essas competências por mais que a gente ache que já adquiriu, muitas delas a gente tem habilidade para usar com grupos menores, em campos de estágio, em pequenos grupos; daí você é o professor com mais competências, da leitura do que o aluno diz, da solicitação do papel que você espera dele como um elemento mais ativo na construção do conhecimento. (E-09)

Relacionadas com a temporalidade no futuro, as entrevistadas citaram as subcategorias perspectivas e incertezas, sendo as primeiras principalmente relativas às mudanças contínuas para preservação da ética do cuidado e a continuidade de ações pedagógicas, internas à unidade de ensino e voltadas para a melhoria da qualidade da formação dos professores e dos alunos. Já com relação aos elementos dificultadores, citam a capacitação como algo inconstante e o desconhecimento do futuro, assim referindo:

A docência para mim é uma ferramenta, quantas vezes eu precisar mudá-la eu vou mudar para fazer com que esse princípio da ética do cuidado caiba nela. Lá na frente eu não sei como será, o que não posso é perder o eixo fundamental que é a ética do cuidado, eu não sei como ela vai acontecer, pois ela simplesmente está acontecendo. Eu não consigo ver competências individuais, acho que as competências coletivas são aquelas que melhor representam o pulsar dos sonhos, desejos, crenças, projetos e habilidades. Não sinto necessidade de desenvolver habilidades individuais, sinto necessidade de desenvolver habilidades coletivas, integradoras, complementares, com cumplicidade. (E-01) 
Acho que a gente teria que desenvolver como competência, poder estar ensinando de forma mais aprazivel, poder estar ministrando de forma mais aprazível eu tenho pensado muito nisso, ensinar dessa forma em qualquer nível. Agora para essa competência eu não sei. (E-02)

A universidade deve começar oferecer de maneira mais contínua, eles estão com um programa permanente de capacitação pedagógica, mas eles já tem oferecido algumas coisas e dentro do possivel tenho participado, então vou, já fui em congresso, em curso de capacitação para docente, pedagógico, então aproveito. (E-03)

Eu gostaria de desenvolver a competência de ter mais facilidade para redação, tenho um pouco de dificuldade em escrever um trabalho cientifico, de escrever, de colocar as palavras adequadas. (E-04)

Acho que precisa a Instituição investir mais no docente porque acho muito difícil, não 0 fato de você. ter que pagar o curso que vai fazer, mas o que me deixa muito chateada é a dificuldade que a gente tem de sair para fazer esses cursos, para trazer o que é bom para aluno, e quando chega aqui não só tem que repor tudo, mas é muito burocrático, o negócio é muito burocrático, parece que ele não favorece nada ao docente e isto é muito desestimulador. Eu acho que a gente está sempre precisando desenvolver nossas competências, só sabe das competências que a gente não desenvolveu, quando se depara com situações. (E-04)

Hoje o meu desejo seria manter essa linha que eu acredito, trabalhar muito na base dos valores, da ética, do compromisso, de uma aplicação eu diria mesmo edificante dos conhecimentos para gerar atitudes, profissionais mais responsáveis, mais posicionados, mais comprometidos e a possibilidade de uma organização didático-pedagógica que permita que a gente faça isso e que tanto a eles quanto a mim dê a segurança de que alguma coisa aconteceu. (E-05)

A continuidade, acho que seria nessa linha mesmo, acho essa última pergunta mais difícil de responder porque, que competências que a gente acha que deve desenvolver, a gente só sabe o que deve desenvolver se a gente tiver consciência delas então acho que o que desenvolver já está tentando. (E-06)

Acredito muito que a construção da capacitação deva ser interdisciplinarrmente; se você não tiver essa coisa interdisciplinar, sozinha com meu conteúdo não vou conseguir construir muita coisa nem me capacitar muito. (E-07)

Uma área que eu precisaria me dedicar mais, seria a área da pesquisa. Eu acho que isso poderia inclusive, qualificar meu trabalho, permitir a inserção de mais alunos no projeto de pesquisa, no projeto de iniciação científica dentro da escola, então a gente é um pouco tímida ainda nisso. (E-08)

Capacitação é a tal da coisa inconstante... não só para docente, para área especifica. Estamos num mundo em movimento e movimento rápido, então acho que as pessoas aprendem a ser desse jeito, vivem fazendo buscas, hoje sou uma pesquisadora, tenho que fazer pesquisa, acho como já te falei, a maturidade te dá uma condição de buscar outra ordem, outro tipo de literatura, então, eu acho que a gente está em continua capacitação. Dadas às transformações a gente tem de vivenciar coisas novas, um jeito novo de ser e quando se dá conta, surpreendentemente, vagarosamente, você mudou, cresceu. A gente tem que continuar, então, eu acho que é continuo não tem muito que pen- 
sar a idéia da capacitação para qualquer atividade, então, é para sempre essa capacitação. (E-09)

A análise das falas permite verificar que as professoras têm visões projetivas com relação às mudanças que entendem necessárias, em si próprias, nos alunos e na instituição de ensino para o atendimento das demandas futuras. Nessa direção, Fernandes\&Vaz (1999, p.108) demonstra sua preocupação com o processo de formação dos enfermeiros nas instituições de ensino superior, e sugere sejam viabilizadas formas de inovações, referindo que

Entendendo que a graduação em enfermagem tem influência direta na determinação do perfil do profissional, percebo que os órgãos de formação deveriam refletir mais sobre o seu papel e propiciar espaço de discussão envolvendo todos os segmentos - docentes, acadêmicos, egressos, afim de inovar, e coletivamente, proceder as mudanças necessárias na estrutura atual.

A crença na mudança está presente nas falas das docentes referentes ao futuro, demonstrada pelas perspectivas, esperanças, além das incertezas e dos medos. Conforme as falas captadas, as docentes acreditam ser possível a mudança nas condições da sociedade por intermédio da educação. Isto nos remete a Paulo Freire, que, a respeito da mudança, afirma:

Mudança e estabilidade resultam ambas da ação, do trabalho que o ho-
mem exerce sobre o mundo. Como um ser de práxis, o homem, ao res-
ponder os desafios que partem do mundo, cria o seu mundo: o mundo
histórico-cultural. [...] Enquanto a mudança implica, em si mesma, uma
constante ruptura, ora lenta, ora brusca, da inércia, a estabilidade encar-
na a tendência desta pela cristalização da criação. Enquanto a estrutura
social se renova através da mudança de suas formas, da mudança de
suas instituições econômicas, políticas, sociais, culturais, a estabilidade
representa a tendência à normalização das estruturas. (1983, p.46)

Estes excertos captados nas entrevistas foram sintetizados no Relatório Síntese, apresentado a seguir.

\subsection{2 - Relatório Síntese}

Este é o Relatório Síntese, disparador do Grupo Focal:

As categorias e subcategorias elaboradas a partir dos dados coletados junto aos sujeitos, por meio das entrevistas, foram sintetizadas, conforme as tendências relacionadas à questão de quando e como se deu o desenvolvimento de competências para a docência, bem como o aponta- 
mento da influência das características pessoais e da unidade de ensino como intervenientes neste processo. Ressalte-se ainda, o apontamento de perspectivas para o futuro e as incertezas quanto a este.

O aspecto temporalidade no desenvolvimento de competências para a docência, evidencia experiências tanto vivenciadas no passado, como no presente. As que emergem do passado apontam para: uma trajetória que em alguns casos, iniciou-se com experiências vivenciadas na vida acadêmica; os sujeitos participantes, em sua maioria, obtiveram sua capacitação após inserção no mundo do trabalho educacional, de forma empírica, na vivência do cotidiano docente com reforço enfático, na competência técnica e posteriormente, em nível formal para a área da docência, por meio de cursos de mestrado, doutorado e outros na área pedagógica; as relações interpessoais entre professor/aluno e o conhecimento específico na área da educação reforçam o desenvolvimento da capacitação para a docência.

Consideram que os aspectos facilitadores apontados revelam a importância das vivências no cotidiano profissional da docência e a capacitação pedagógica. Já, os dificultadores referem-se à falta desta mesma capacitação pedagógica. Como características pessoais indicam a vocação, o interesse e a disposição para o aprendizado, bem como o autoconhecimento e autonomia intelectual como meio para a busca contínua do desenvolvimento.

Não existe uma terminalidade das competências no passado, e sim o desenvolvimento das competências no presente, que são agregadas e complementam as que emergiram no passado.

As que emergem do presente apontam uma trajetória, que indica a continuidade da capacitação por meio da reflexão sobre a prática profissional, levando ao desenvolvimento da capacitação em termos do aprimoramento específico na área de educação agregando, autonomia intelectual, com vistas à construção do conhecimento e transformação da realidade. Os aspectos facilitadores indicados referem-se tanto à vivência acadêmica como a profissional-assistencial, tendo como alicerce para o processo ensino-aprendizagem a capacitação e a educação continuada. As características pessoais que influenciam referem-se à crença na transformação social e à ética do cuidado como eixos norteadores para o desenvolvimento de competências. Como influência da unidade de ensino, compreendem desde a capacitação formal, perpassando por vivências do cotidiano, que levam à autonomia intelectual.

O aspecto temporalidade no desenvolvimento de competências emerge com perspectivas para o futuro, na busca de desenvolvimento de estratégias pedagógicas, que envolvam o aluno - parecendo ser este o grande desafio, e na importância da continuidade da capacitação pedagógica, pautada em valores éticos, que permitam a construção de competências e habilidades coletivas pa- 
ra o fazer pedagógico. Emergem também incertezas, uma vez que o futuro sempre reserva algo incerto pelo desconhecido.

\section{2 - Grupo focal: a hermenêutica-dialética}

Para atender o objetivo da pesquisa, "intervir nesse processo, por meio da reflexão sobre a prática docente, por eles explicitada", foi programada a realização de uma reunião do grupo focal.

O local escolhido para a realização do encontro foi uma sala ampla, com iluminação e ventilação adequadas, com cadeiras confortáveis ao redor de uma mesa de reunião, que comportou todos os componentes do grupo focal. Esta sala localiza-se no prédio administrativo do Centro de Ciências da Vida da PUCCampinas, em área anexa à sala dos professores.

Seguindo essa proposta, a pesquisadora do estudo participou da reunião do grupo focal na qualidade de facilitadora, enquanto um colega do Curso de Enfermagem da UNIFEOB ${ }^{60}$ cumpriu o papel de observador, anotando e registrando dados e informações não verbais, que passaram a integrar o conjunto de dados levantados.

O grupo recebeu informações sobre a técnica de grupo focal, assinou o Termo de Consentimento Livre e Esclarecido e foi registrada a caracterização dos sujeitos participantes. Após a explicação inicial, foi dada a orientação que deveriam elaborar um constructo coletivo segundo o entendimento dos significados aprendidos a partir da leitura individual da síntese apresentada, utilizando, para este momento coletivo, retalhos de tecidos, cola, cartolina e tesouras.

O grupo desenvolveu a tarefa mantendo a temporalidade segundo as vivências do passado e do presente e a perspectiva do futuro.

Foi realizada a transcrição na íntegra das falas dos sujeitos, incluindo-se os gestos, as emoções e outros elementos captados pela facilitadora e pelo observador, que aparecem no texto entre parênteses (Anexo 9). Respeitando as categorias surgidas na primeira fase de análise das falas das entrevistadas, foi mantida a temporalidade de significados, encontradas no passado, no presente e no fu-

\footnotetext{
${ }^{60}$ Centro Universitário da Fundação Educacional "Octávio Bastos", situada em São João da Boa Vista (SP).
} 
turo. Visando a manutenção do anonimato, na transcrição das falas os nomes das participantes do grupo focal foram substituídos por nomes fictícios (flores).

\title{
6.2.1 - A análise das falas: a hermenêutica dialética
}

Para as fases de categorização e tratamento dos resultados conforme 0 quadro teórico proposto desta pesquisa, os pontos de referência gerais foram as categorias analíticas, que conforme Minayo (1996), não precisam estar presentes no discurso teórico que organiza o projeto da pesquisa, no qual devem constar definições que se fazem necessárias para surgir, do caos inicial, o objeto específico com seus contornos gerais. A respeito das categorias analíticas e empíricas, a autora afirma ainda que

\begin{abstract}
As primeiras são aquelas que retêm historicamente as relações sociais fundamentais e podem ser consideradas como balizas para o conhecimento do objeto nos seus aspectos gerais. Elas mesmas comportam vários graus de abstração, generalização e aproximação. As segundas são aquelas construídas com finalidade operacional, visando o trabalho de campo (a fase empírica) ou a partir do trabalho de campo. Elas têm a propriedade de conseguir apreender as determinações e as especificidades que se expressam na realidade empírica. (op.cit, p.94)
\end{abstract}

As categorias empíricas, segundo Minayo (op.cit.), são construídas a partir dos elementos captados nas falas do grupo social representado pelos sujeitos da pesquisa, tendo todas as condições de serem colocadas em um quadro mais amplo de compreensão teórica da realidade e de, ao mesmo tempo, expressá-la em sua especificidade, permitindo avançar o conhecimento a partir das categorias analíticas definidas.

Paulo Freire (1983; 2004), destacando o caráter histórico da educação, afirma que ela "só é possível para o homem, porque este é inacabado e sabe-se inacabado", reconhecendo com isso, que para os homens, "aprender é construir, reconstruir, constatar para mudar", sendo o resultado de um processo de superação constante. Para o autor,

O mundo não é. O mundo está sendo.(...) Não sou apenas objeto da História mas seu sujeito igualmente. No mundo da História, da cultura, da política, constato não para me adaptar mas para mudar.

Neste sentido, observando que a temporalidade emergiu como importante fio condutor das falas captadas na primeira fase da pesquisa, as categorias analí- 
ticas subjacentes no referencial teórico, foram o passado, o presente e o futuro, representadas no esquema da figura 6.2.a.

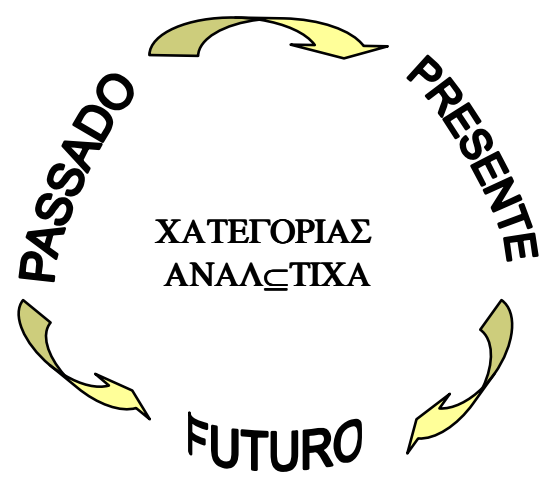

Fig. 6.2.a - Categorias analíticas - esquema

Estas categorias analíticas, relacionadas com a temporalidade, são relevantes na medida em que se busca compreender, nesta pesquisa, quando e como se deu o processo de construção das competências docentes dos entrevistados, sendo necessária a interpretação dos fatos históricos das trajetórias pessoais e profissionais por eles relatados.

A partir dos dados do passado, pode ser resgatado o conjunto de fatos, acontecimentos, condições e fenômenos que caracterizaram o período histórico da pessoa entrevistada, identificando as marcas significativas que iniciaram e viabilizaram, ou não, o processo pesquisado. A mesma intenção ocorre com relação ao presente, por representar o tempo atual, podendo, desta análise, emergir pistas para a explicitação dos fatores conjunturais que persistem na construção das competências.

Com relação ao futuro, por representar um tempo que há de vir, busca-se identificar os pontos a serem atingidos, os projetos de vida e as expectativas, a partir das experiências, vivências e construções acumuladas e em processo de construção.

$\mathrm{Na}$ segunda fase da pesquisa, a partir das categorias analíticas, foram analisadas as falas dos integrantes do grupo focal, resgatadas da discussão dos sujeitos sobre o conteúdo do relatório síntese. Conforme Minayo (1996, p.235), foi realizada a "leitura flutuante, que permite apreender as estruturas de relevância dos atores sociais, as idéias centrais que tenham de transmitir e os momentoschaves de sua existência sobre o tema em foco", permitindo o estabelecimento das "categorias empíricas, confrontando-as com as categorias analíticas teorica- 
mente estabelecidas como balizas da investigação, buscando as relações dialéticas entre elas".

Da análise das falas do grupo focal, emergiram as categorias empíricas que foram denominadas trajetória profissional, características pessoais, unidade de ensino e construção de competências docentes, que se correlacionam com as categorias analíticas da pesquisa, conforme a figura 6.2.b.

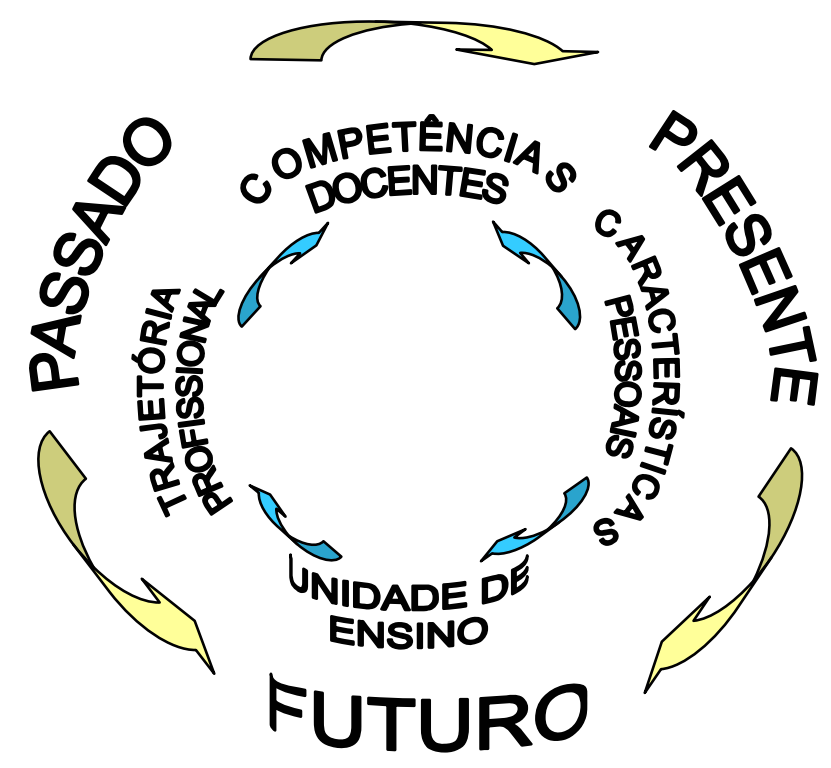

Fig. 6.2.b - Categorias analíticas e empíricas - esquema de correlações.

Para a análise das falas captadas, nesta segunda fase da pesquisa, recorremos aos determinantes do materialismo histórico-dialético, que se apresenta como possibilidade teórica de interpretação, conforme Pires (1997, p.83), pois

\begin{abstract}
O método materialista histórico-dialético caracteriza-se pelo movimento do pensamento através da materialidade histórica da vida dos homens em sociedade, isto é, trata-se de descobrir (pelo movimento do pensamento) as leis fundamentais que definem a forma organizativa dos homens através da história. Este instrumento de reflexão teórico-prática pode estar colocado para que a realidade educacional aparente seja, pelos educadores, superada, buscando-se então a realidade educacional concreta, pensada, compreendida em seus mais diversos e contraditórios aspectos.
\end{abstract}

Com base neste método e tendo em vista a modalidade adotada para a presente pesquisa, os determinantes definidos para esta fase foram os estruturais, particulares e singulares, envolvendo os seguintes aspectos:

- determinantes estruturais: relacionado à trajetória histórica e à formação dos docentes; 
- determinantes particulares: relacionado à unidade de ensino, seu contexto, suas políticas e relacionamento com o mercado de trabaIho;

- determinantes singulares: as competências docentes dos profissionais dos cursos de enfermagem.

A imbricação entre as categorias analíticas (passado, presente e futuro), e as categorias empíricas (trajetória profissional, características pessoais, unidade de ensino e construção de competências docentes), analisadas à luz dos determinantes que compõem o universo das relações sociais no lócus da pesquisa (determinantes estruturais: relacionado à trajetória histórica e à formação dos docentes; determinantes particulares: relacionado à unidade de ensino, seu contexto, suas políticas e relacionamento com o mercado de trabalho; determinantes singulares: as competências docentes dos profissionais dos cursos de enfermagem), é o ponto central da análise das falas e da interpretação dos dados coligidos, conforme a figura 6.2.c.

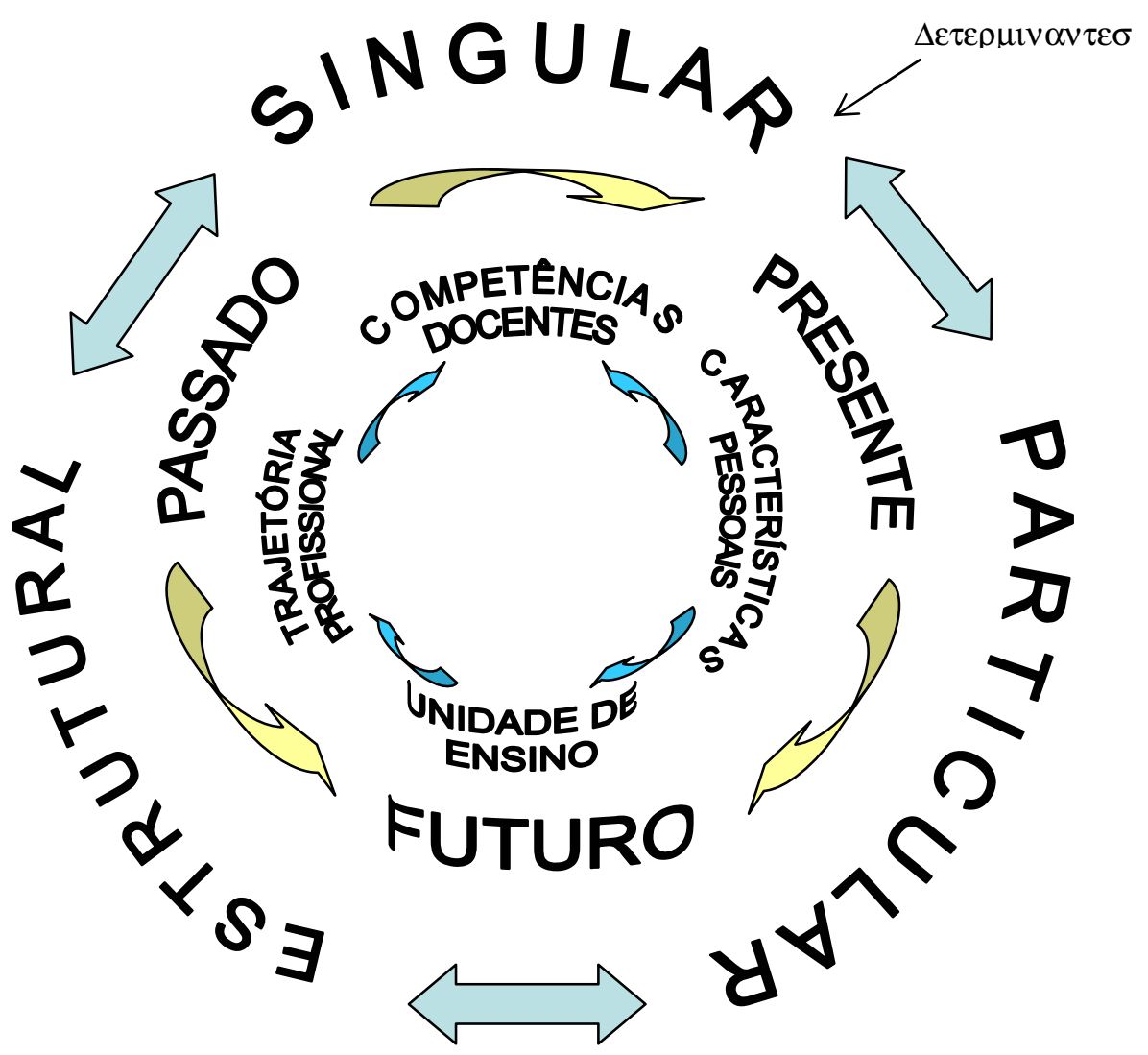

Fig. 6.2.c - Determinantes, categorias analíticas e empíricas - esquema das correlações. 


\subsection{2 - Os determinantes estruturais}

A dimensão estrutural compreende a trajetória histórica da formação dos docentes, cujos eixos fundamentais são as políticas educacionais e os valores dos professores enquanto atores e sujeitos da ação pedagógica. Ao longo da trajetória da educação, os embates destas forças caracterizaram momentos significativos no desenvolvimento das funções docentes, em especial com relação às suas competências.

Com efeito, de um lado, a historicidade e a dinamicidade dos diferentes momentos histórico-sociais que configuraram o sistema educacional do país, definiram no Plano Nacional, a pouca participação dos professores na construção histórica do sistema educacional, que agora se apresenta voltado para a lógica da produtividade e eficácia. Por outro lado, a dinâmica da mundialização, movida pela visão capitalista, na história da educação, pode ser entendida como representada pelos interesses de grande parcela das instituições privadas de ensino em assumir (e lucrar) o sistema educacional, e por diferentes segmentos empresariais e industriais, que preconizam modelos hegemônicos de educação mais voltados para o atendimento da lógica do mercado.

Os três séculos iniciais da história brasileira, praticamente perdidos em termos de educação, afastaram nosso país dos avanços alcançados nos países da Europa e América do Norte, e o resultado das tardias modificações ocorridas no sistema de educação do país, repercutiu sob a forma de um déficit acumulado no atendimento da população.

Recuperando este movimento histórico, pode-se considerar que as diretrizes gerais de funcionamento da instituição escolar moderna (como a organização em séries; ser destinadas a todos; com especialistas na área docente - os professores; e com a utilização de espaço e materiais próprios), foram propostas em 1670 por Comenius, que estabeleceu

\footnotetext{
um formato educacional que vigorará nos séculos seguintes: a escola, local específico destinado à educação de crianças e jovens; o professor, detentor de saber que the permite realizar a função prescrita para a escola; e o conhecimento, conjunto seletivo da cultura sancionada socialmente. (VALDEMARIN, 2004, p.166)
}

Para Comenius, monge de formação, além da substituição de clérigos por professores leigos, a educação deveria ser fundamentada em três eixos principais, representado pelo conteúdo a ser ensinado (a natureza), pelo aluno (do qual 
se conhece o processo de aprendizagem) e pelo professor, sendo este o portador do método que garante que os conteúdos serão efetivamente ensinados aos alunos na escola. Segundo ele, seria possível ensinar tudo e a todos (já que todos eram "filhos de Deus), afirmando que "a arte de ensinar, própria do professor, é verificada pela atividade do aluno, ambas entrelaçadas pelos procedimentos metódicos" (id.ibid.).

Cerca de 100 anos depois, já nos meados do século XVIII, surgem os tratados de Rousseau, que, diferentemente de Comenius, que preconizara o ensino para todos com base em sua crença, também defendeu que a educação é direito de todos, mas a partir de uma lógica voltada para a construção da cidadania. Também para Rousseau a arte de educar é definidora da função social do educador e do conteúdo a ser ensinado, evidenciando com maior clareza a complexidade da tarefa educativa sob a responsabilidade do professor.

Uma das primeiras preocupações dos reformadores do século XVIII consistiu na definição de regras uniformes de seleção e de nomeação de professores, conforme Nóvoa (1995, p. 17), e esta intervenção do Estado na educação, representou a instituição da profissão docente em níveis nacionais, com o estabelecimento de licenças para lecionar, "verdadeiro suporte legal e delimitador do campo profissional." No entanto, no final do século XVIII, considerado por Luzuriaga (1969) como o período-chave para a história da educação e da profissionalização da docência, enquanto inúmeros estudiosos buscavam delinear o perfil do professor ideal e produziam enormes avanços na área da educação, ainda era proibida a instalação de escolas no Brasil.

Estas correntes de pensamento originadas em Comenius e Rousseau influenciaram a maioria dos sistemas educacionais na época - e permanecem parcialmente ainda em vigor até a atualidade, mas, ambas continham a mesma centralidade: o processo de ensino/aprendizagem centrado no professor e em seus conhecimentos. Esta convicção foi considerada equivocada e revertida a partir de 1916, quando Dewey ${ }^{61}$ propôs o deslocamento do eixo do processo de ensino/aprendizagem do professor para o aluno, ou seja, criou um novo modelo edu-

\footnotetext{
${ }^{61}$ Publicada nos EUA em 1916 com o título Democracy and Education, somente chegou ao Brasil em 1936. Dewey não aceitava a educação pela instrução, proposta por Herbart, propondo a educação pela ação; criticando severamente a educação tradicional, principalmente no que se refere a ênfase dada ao intelectualismo e a memorização. Para ele, o conhecimento é uma atividade dirigida que não tem um fim em si mesmo, mas está dirigido para a experiência. As idéias são hipóteses de ação e são verdadeiras quando funcionam como orientadoras dessa ação.
} 
cacional que aliava de uma nova maneira, a teoria do conhecimento, o conteúdo a ser ensinado e o trabalho a ser realizado pelo professor.

Dewey via a escola como instrumento ideal para estender a todos os indivíduos, os benefícios de uma sociedade democrática, tendo a educação uma função de igualar as oportunidades, de onde vem a concepção do "otimismo pedagógico" da escola nova, tão criticado pelos teóricos das correntes crítico-reprodutivistas. Segundo Dewey, o processo de ensino-aprendizagem, estaria baseado na compreensão de que o saber é constituído por conhecimentos e vivências que se entrelaçam de forma dinâmica, distante da previsibilidade das idéias anteriores, pois os alunos e professor detêm experiências próprias, que são aproveitadas no processo. Enquanto o professor possui uma visão sintética dos conteúdos, os alunos possuem uma visão sincrética, o que torna a experiência um ponto central na formação do conhecimento, mais do que os conteúdos formais. Outra condição é o conceito que a aprendizagem é essencialmente coletiva, assim como é coletiva a produção do conhecimento.

As inúmeras doutrinas pedagógicas surgidas a partir desta época entraram em conflito, o que gerou o surgimento de um movimento voltado para o desenvolvimento da escola de massas, a "Escola Nova", provocando a profissionalização do professor, seguida de políticas de controle estatal, fortemente disciplinante, transformando-os em agentes dos novos projetos sociais e políticos da modernidade (Nóvoa, 1995, p.22). Estas modificações não foram acompanhadas de transformações do processo educacional e a cientificidade na educação, tendo perdurado até meados do século passado, quando suas principais teses passaram a ser contestadas por novos movimentos críticos.

Esta expansão dos sistemas de ensino não só não democratizou a educação, mas também, criou novas formas de discriminação e exclusão social, fazendo com que os professores passassem a ser vistos, pela sociedade, como responsáveis pela manutenção de um ensino reprodutivista, mergulhando a profissão docente em uma crise de identidade que se estende até hoje, principalmente em decorrência da racionalização do ensino e da proletarização da profissão docente. Neste sentido, Nóvoa (apud Lüdke, Moreira e Cunha, 1999, p.281), assinala para uma situação paradoxal:

de um lado, uma desvalorização dos professores e de seu status profissional, de outro, sua permanência, no discurso político e no imaginário social, como um dos grupos decisivos para a construção do futuro. Há, 
portanto, uma grande brecha entre a condição real dos professores e o peso que é atribuído à sua ação.

Hubert (1967), Eby(1976) e Saviani (2004) consideram que com o surgimento no século XIX dos países-nações, seus sistemas educacionais foram organizados em termos estruturais, de acordo com duas vertentes de organização política e social, parte voltados para sistemas nacionais estabelecidos com legislação e controle governamental centralizado, modelo adotado pelos países europeus, enquanto outros buscaram a descentralização e municipalização do ensino, sem legislação única, modelo este adotado na América do Norte.

Embora em termos de processo ambos os modelos possam ser considerados equivalentes, os resultados obtidos pelo europeu foram mais homogêneos, possibilitando a erradicação do analfabetismo e o estabelecimento de um patamar comum de cultura com acesso com certo grau de igualdade de condições, para todas as camadas sociais. Por outro lado, o modelo americano apresenta grandes distorções e desigualdades sociais, motivo de preocupações dos governos atuais que adotaram o modelo não centralizado e nacional ${ }^{62}$.

Saviani (2004) coloca, neste sentido, que no Brasil do século XX, o sistema educacional passou da situação local e de pequenas proporções, próprio de um país predominantemente rural, para um sistema nacional e de grande escala, similar ao modelo europeu, em função do incremento populacional e crescimento econômico, com altas taxas de urbanização e industrialização. As estruturas do sistema educacional não acompanharam esta modificação, resultando o citado déficit para com a sociedade em termos de educação em massa e a política educacional atual tem se direcionado para o modelo americano, objetivado pela transferência das responsabilidades do ensino público da esfera federal para a municipal, e pela significativa privatização do ensino superior.

As modificações em curso no modelo educacional brasileiro estão ligadas às ocorridas no modo de produção, que passou do taylorista-fordista para o sistema de acumulação flexível (Harvey,1992), e decorrem das pressões originadas no mercado de trabalho globalizado. Observando o panorama mundial, constatase que, em decorrência à globalização das economias e sociedades, os países desenvolvidos passaram a exercer fortes influências sobre os países em desen-

\footnotetext{
62 Saviani (2004) afirma que como o Brasil sequer obteve a extinção do analfabetismo (passando de $85 \%$ de analfabetos em 1890 para 33\% em 1991, ressaltando que este contingente atinge a cifra de 50 milhões de analfabetos) e adotou basicamente o modelo americano de educação com algumas variantes, sem que tenha sido alcançada a universalização da educação, os desafios que se apresentam para os novos profissionais envolvidos na área educacional são enormes.
} 
volvimento, consagrando a dicotomia desenvolvimento / subdesenvolvimento, utilizando para tanto, grande número de organismos internacionais de controle, gestão e de fomento, entre os quais se destaca a presença do Banco Mundial. Em função de suas múltiplas atividades e poderio econômico, este órgão tem influenciado as políticas públicas de países em desenvolvimento, com repercussões, na esfera da educação, sobre a formação de professores nos países em que atua, propondo, por intermédio de seus manuais, textos de convênios e contratos de financiamento, medidas estruturais que enfatizam a formação em serviço, em detrimento da formação inicial, por ser este tipo de capacitação aquele que rende mais com menor custo, em sua ótica nitidamente funcionalista e monetarista.

Entre outras propostas do Banco Mundial, destacam-se as que estabelecem a educação segundo perspectivas de custo-benefício, com favorecimento das leis de mercado e a aproximação entre as imagens da escola e da empresa, com crescente flexibilização nas relações trabalhistas, fruto da racionalidade e da eficiência técnica preconizadas pelos novos gestores das economias transnacionais. No entanto, segundo Lüdke, Moreira e Cunha (1999, p.284),

\footnotetext{
a maioria das propostas do Banco Mundial sobre a educação básica para dirigidas ao Terceiro Mundo fundamenta-se em estudos e autores do Primeiro Mundo e dos bancos e agências internacionais, havendo um abismo entre o discurso internacional sobre a educação dita universal, adotado pelo Banco Mundial, e o discurso educativo nas esferas regionais e nacionais.
}

Quanto à esfera da enfermagem, a dimensão estrutural também se apresenta na Resolução CNE/CES no. 3/2001, que regulamentou as Diretrizes Curriculares Nacionais do curso de graduação em enfermagem. Com base na flexibilização curricular, este documento prevê a formação do enfermeiro generalista, humano, crítico e reflexivo, tendo como base o rigor científico e pautado em competências e habilidades, conteúdos essenciais e indicadores de avaliação. Verifica-se, no entanto, que as várias transformações que vêm ocorrendo na legislação que disciplina o funcionamento dos cursos de graduação em enfermagem no Brasil, vêm sendo "influenciadas pelas escolas e pelos modelos de currículo mínimo obrigatório, legalmente determinado, adaptando-se às políticas de saúde emergentes e ao modelo de privatização dos serviços de saúde" (SAUPE, 1998, p.37). 


\subsection{3 - Os determinantes particulares}

A dimensão particular engloba a unidade de ensino e as suas relações com o trabalho docente, tendo como fio condutor suas características pedagógicas e educacionais, fruto das transformações ocorridas ao longo da trajetória histórica. Gómez (1998) destaca que, como os processos de socialização direta das novas gerações (família, grupos sociais iguais, etc.) se tornaram ineficazes em função da acelerada complexificação das estruturas e multiplicação de tarefas na vida das sociedades, as escolas, enquanto unidades de ensino, foram concebidas como instituições especificamente destinadas a desenvolver esta socialização das novas gerações, como garantia da reprodução social e cultural, voltadas para a sobrevivência mesma da sociedade. Assim,

surgem desde o início e ao longo da história diferentes formas de especialização no processo de educação e socialização secundária (tutor, preceptor, academia,escola religiosa, escola laica...), que conduziram aos sistemas de escolarização obrigatória para todas as camadas da população nas sociedades contemporâneas. Nestas sociedades, a preparação das novas gerações para sua participação no mundo do trabaIho e na visa pública requer a intervenção de instâncias específicas como a escola, cuja peculiar função é atender e canalizar o processo de socialização. (GÓMEZ, 1998, p.13)

Mesmo não sendo a única instância social responsável pela reprodução da (de)formação dos novos indivíduos, já que outras, tais como as famílias, os grupos sociais, as igrejas, os meios de comunicação igualmente se incumbem desta tarefa de reprodução de sentidos, continua o autor, a escola especializa-se exatamente "no exercício exclusivo e cada vez mais complexo e sutil de tal função, por seus conteúdos, por suas formas e por seus sistemas de organização", inculcando nos estudantes, paulatina e progressivamente, as idéias, as concepções de mundo, as disposições e os modos de condutas determinados e consagrados ideologicamente pelas sociedades.

No final do século XX, a escola, já entendida como uma instituição voltada para o ensino em massa e, portanto, voltada idealmente para a homogeneização social, passa a ser claramente baseada no paradigma do modelo industrial de produção, legitimada por políticas de democratização e pela ampliação das demandas sociais por educação. Esta nova conformação se traduz no aumento do ensino laico e na instauração de uma ideologia pedagógica com caráter meritocrático, centrada na profissão e voltada para propiciar condições de absorção pelo mundo de trabalho. 
Nesta lógica educacional, a preparação para o mundo do trabalho requerida exige o desenvolvimento, por parte dos estudantes, não só, nem principalmente, de novos conhecimentos, técnicas, idéias, habilidades e competências formais, mas também e principalmente, da aceitação de disposições, adoção de atitudes e comportamentos ajustados às exigências e características dos postos de trabalho, da organização das empresas e das instituições das sociedades.

Analisando a escola em seus diferentes momentos históricos, Cunha (2004) afirma que ela certamente mostrará realidades igualmente diferenciadas. Para a autora,

Se o professor refletir sobre si mesmo, sua trajetória profissional, seus valores e crenças, suas práticas pedagógicas, encontrará manifestações não-semelhantes, ao longo do tempo. Este jogo de relações entre a escola e a sociedade precisa ser, cada vez mais, desvendado para que se possa compreender e interferir na prática pedagógica. (p.24)

Além da formação técnica e científica, específicas na área da graduação, as instituições de ensino assumem, também, do processo de socialização do estudante voltado para sua formação como cidadão capaz de intervir na vida pública, ou seja, a escola busca prepará-lo para se incorporar à sociedade de modo que se possa manter a dinâmica e o equilíbrio das instituições, bem como as normas de convivência que compõem o respectivo tecido social. Neste sentido, afirma Gómez (1998), entendendo que as sociedades contemporâneas capitalistas são governadas pela implacável e, às vezes, selvagens, leis do mercado na esfera econômica, necessariamente a escola assume as vivas contradições que marcam sua atualidade, mas prossegue sua trajetória histórica, legitimando a "ordem" estabelecida e se converte em válvula de escape das contradições e desajustes sociais. Para Engita (1990), citado por Gómez (1998, p.17),

\footnotetext{
A escola é uma trama de relações sociais materiais que organizam a experiência cotidiana e pessoal do aluno com a mesma força ou mais que as relações de produção podem organizar as do operário na oficina ou as do pequeno produtor. Por que então continuar olhando o espaço escolar como se nele não houvesse outra coisa em que se fixar além das idéias que se transmitem?
}

A unidade de ensino é uma instituição na qual os processos de socialização ocorrem como conseqüência das práticas sociais e das relações interpessoais que se estabelecem em determinado grupo social e em um determinado cenário institucional, de tal forma que os estudantes apreendem teorias, disposições e condutas, não apenas em decorrência da transmissão de conhecimentos oficialmente explicitados nos currículos oficiais, mas principalmente em função 
dessas interações sociais, presentes na instituição, no curso ou na aula. No entanto, como os currículos e normas legais relativas ao curso são homogeneizantes e impostas por órgãos externos às unidade de ensino, ocorrem descompassos entre as realidades sociais do local com relação às legalmente instituídas. Assim, provocando desinteresse em grande parte dos alunos, o processo de aprendizagem acadêmica se torna uma atividade voltada apenas para "passar nos exames e esquecer depois", enquanto a aprendizagem dos mecanismos, estratégias, normas e valores de interação social, que são requeridos pela complexa vida acadêmica e pessoal dos alunos, configuram-se paulatinamente em representações e pautas de condutas que se estendem para além do ambiente escolar, notadamente para o mercado de trabalho.

No contexto atual, em decorrência dos impactos da forte crise econômicofinanceira ocorrida nos anos $80^{63}$ e que afetou todos os países, inclusive os industrializados, eclodiu uma erosão geral na crença da existência de uma conexão lógica entre a obtenção de um diploma de nível superior - relacionado à construção de saberes, com a ascensão social, técnica e financeira das camadas sociais menos privilegiadas. Com isto, os saberes adquiridos na escola parecem não mais ser socialmente úteis na ótica do mercado de trabalho, fazendo com que ocorra, por um lado, a crescente desvalorização dos saberes e da profissão docente, repercutindo em sua proletarização, citada por Nóvoa (1998, 1999), e por outro lado, o desenvolvimento de uma lógica de consumo com relação a estes saberes construídos, sob a égide da instituição de ensino, que

\begin{abstract}
deixaria de ser um lugar de formação para tornar-se um mercado onde seriam oferecidos, aos consumidores (alunos e pais, adultos em processo de reciclagem educação permanente), saberes-instrumentos, saberes-meios, um capital de informações mais ou menos úteis para o seu futuro "posicionamento" no mercado de trabalho e sua adaptação à vida social. As clientelas escolares se tornariam então clientes. (Tardif, 2002, p.47)
\end{abstract}

Sob a lógica de consumo, os saberes passaram a ser definidos em função das pressões dos consumidores e da evolução, mais ou menos tortuosa, do mercado de trabalho, modificando a função primordial dos professores - formar indivíduos cidadãos, voltando-se para equipá-los para atendimento aos ditames do mercado de trabalho. Ao invés de formadores, continua Tardif (2002), os pro-

\footnotetext{
${ }^{63}$ Referente à mudança do padrão-ouro para padrão dólar norte-americano, o que provocou elevação das dívidas assumidas pelos países emergentes junto aos órgãos de financiamento e de fomento, agravada pela crise causada pelo "choque do petróleo" sobre estas economias, afetando principalmente os países em desenvolvimento e subdesenvolvidos, que causou repercussão em muitos países desenvolvidos.
} 
fessores seriam muito mais informadores ou transmissores de informações potencialmente válidas e utilizáveis pelos "clientes" dos cursos.

Também em decorrência desta crise, houve a falência do milagre brasileiro, obrigando as esferas de governo a proceder à reorganização de suas políticas sociais, especialmente com relação aos sistemas previdenciário e de saúde pública, ocasião em que a Enfermagem redefiniu suas práticas, havendo o deslocamento da intervenção sobre o doente para a atenção ao sadio. Assim, ressaltam Geib, Migott, Carvalho, Mocinho (1999, p.87),

\begin{abstract}
Nas instituições de ensino, passou-se a discutir a formação do enfermeiro generalista, adequado para esse novo modelo de atenção à saúde, com característica de simplificação, extensão de cobertura, atividades preventivas e ambulatoriais e de integração multidisciplinar e multiprofissional. [...] Esse período deu início ao movimento de libertação da produção do saber em enfermagem. Wanda Horta, no Brasil, e as teoristas americanas, ainda que de forma incipiente, construíram as condições de possibilidade para a emergência de um novo paradigma.
\end{abstract}

A busca do saber em Enfermagem aproxima a prática da enfermagem com a prática da educação, na medida em que o enfermeiro, na condição de educador, utiliza o processo ensino/aprendizagem em todas as suas ações de cuidado, encaradas como sendo aquelas dirigidas não só ao paciente e família, mas também aos alunos, à equipe de enfermagem e aos procedimentos técnicos, visando atingir seu objetivo, requerendo, uma competência reflexiva em busca de uma ação mais efetiva. Para tanto, a graduação em enfermagem não pode ser direcionada apenas pela lógica do mercado de trabalho,

Encaminhar o ensino de graduação apenas do ponto de vista do mercado é tratá-lo sob a ótica do lucro, do capital, negando a natureza mesma do processo educativo. É privilegiar o saber imediato, quase instantâneo, o aprendizado da execução, do saber-fazer, a urgência, a eficiência e a eficácia típicas do mercado como elementos norteadores de nosso trabaIho, em detrimento do cultivo do raciocínio, da reflexão, da criação, ou seja, caminhar no sentido oposto ao da humanização do homem. (COÊLHO, 1998, p.2)

Devido às suas peculiaridades, o ensino de enfermagem é realizado em um ambiente social específico ligado ao sistema de saúde, onde os fenômenos pedagógicos são realizados por meio de uma relação dimensionalmente complexa, na medida em que além do professor e aluno, existe a pessoa do paciente.

Esta conformação faz com que, ao sujeito da ação pedagógica, seja necessário algo mais do que a formação técnica e científica, representado pela inclusão de uma formação ética, obrigando que o professor assuma de forma com- 
petente, esta função, voltada para a transformação social, conforme relatado pelas docentes:

Nós somos docentes, estamos discutindo isto aqui e não dá para separar essas coisas. Quando está se orientando o aluno aqui de enfermagem, essa coisa da enfermeira não tem como separar. Então, é como você falou \{referindo à Estrelitza\} que você usa a PUCC para fazer saúde pública, a gente está aqui fazendo transformação social, não é isso? E defendendo o cliente cirúrgico, defendendo o outro, cada um no seu espaço. (Violeta)

É verdade, eu me sinto mais professora quando estou atuando do que quando estou em sala de aula. Essa diferença de contextos, espaciais, territoriais, que para mim tem um significado também. (Estrelitza)

Até por que você está numa relação com o aluno lá, numa coisa que é real, que é concreta, que você pode ou não, daí dependendo da sua ação, transformar. (Rosa)

As falas captadas demonstraram que os professores do curso de enfermagem se reconhecem como enfermeiras de formação, realçam a trajetória profissional e assumem que a experiência prática no ambiente da saúde repercutiu na atividade docente, objetivando claramente:

Eu estou ouvindo vocês falarem e gostaria de dizer que este rosinha que aponto aqui \{no laço feito no retalho\} é a minha identidade como enfermeira e não como docente. Eu cheguei aqui na Universidade como enfermeira. (Estrelitza)

Eu peguei um tecido aqui, bem colorido, porque agora vendo a síntese, me fez recordar, porque eu fui entrevistada também. Quando houve a entrevista eu peguei meu percurso desde o técnico, passando pela experiência como enfermeira em uma unidade de internação, com um momento rico de compartilhar com alunos, professores e também num momento de explodir mesmo, em conhecimento e veio mesmo a chance oficial, concreta, então, para mim também foi muito bom poder iniciar e colocar em prática tudo aquilo que eu já acreditava e que vinha da minha experiência do hospital universitário. Bom, depois a gente vê o presente, mas o passado é algo muito mesclado e muito colorido. \{risos do grupo\}. (Rosa)

Eu utilizo dessa docência para defender a saúde pública, eu tenho uma relação muito clara com a minha docência, então eu continuo me sentindo..., por isso que estou presa aqui \{aponta para o passado na cartolina\} porque sou uma enfermeira de saúde pública e para fazer saúde pública eu uso a PUCC \{ênfase\}. Eu uso a PUCC para defender 0 SUS. (Estrelitza)

A existência de preocupações com a unidade de ensino (UE) foi exteriorizada nas falas das docentes, que demonstram ter a UE representado, em muitos momentos, componente facilitador para o processo de construção das competências docentes, possibilitando a melhoria das relações interpessoais e a transformação social, muito embora tenham se ressentido, em muitos momentos, de meIhores condições de trabalho, principalmente no tocante ao reconhecimento da amplitude de suas atividades. 
Acho que quando você fez a pergunta, facilitadora, da fala da Lírio, quer dizer, de onde vem essas incertezas, as angústias, eu acho que tem um fator muito importante que é a relação trabalho quando ele está institucionalizado e, nós todos somos institucionalizados. Aqui ou acolá e isto tem uma influência muito grande, você estar institucionalizado, porque assim, a vida acontece na relação com o trabalho e, você está dentro de uma instituição. Então acho que até neste momento, em que a Lírio diz desse ir e vir, ela está sendo influenciada no âmbito em que você convive, que é institucional, então, eu acho que até para você sobreviver aqui de maneira geral, quando você bate o olho, embora tenha os momentos mais obscuros e de maior indefinição, predomina a idéia da clareza da vontade do querer, entendeu? (Rosa)

Não estou interessada em ser reconhecida como a \{ênfase\} performance. Estou sendo super sincera, gente, porque se não for sincera aqui não tem sentido. Acho que estou de bom tamanho para transmitir o que transmito. (Estrelitza)

Sim, esse lugar, a história é dessa instituição, mas a gente não conhece só ela, e a força como ela está impregnada aqui \{refere-se às cartolinas\} é muito forte e começa a influenciar na tua vida. É um negócio muito doido e esse é o medo, porque ele entrou um dia e lá \{aponta para o passado\} um dia aqui e acaba no presente. (Miosótis)

Em termos das atividades desenvolvidas, as professoras indicam a necessidade da articulação política e a formação solidária das competências como algo necessário para superar as situações dificultadoras provocadas pela unidade de ensino, o que igualmente repercute na continuidade da construção de suas competências docentes. Não há espaços para a ingenuidade, afirmava Paulo Freire, na atividade docente, fato este colocado claramente nas falas captadas:

Acho que para criar esses laços, não existe forma ingênua; nós vamos ter que pensar em articulação que é de outra ordem, que é política. Política no sentido das relações e acho que até por conta desse desenvolvimento de competência política que parece importante não só para ter, mas como nesses espaços que você tem autonomia na sala de aula e tudo mais, que você consegue fazer. Agora, eu acho que até a gente não aprofundou, mas tentou iniciar uma reflexão de âmbito maior. Eu acho que não é ingênuo, tem que ser político, mas ele tem que carregar essa coisa solidária, de estar fazendo, para você de fato fazer a transformação porque se você pegar o político, no meu entendimento, é só aplicar para fazer valer alguma coisa que a gente acredita, mas, se não for verdadeiramente solidário, a ponto de acreditar no outro e nas outras coisas, você também não vai conseguir transformar, a gente só vai viver períodos de menor possibilidade, daí eu fico imaginando, o que a gente fica esperando? Voltar a um período de possibilidade, tentar ajudar ou a gente pode ter ações e verdadeiramente tentar ajudar a transformar e transformar o outro mesmo, porque eu não acho que o outro é impossivvel de ser transformado. Então eu vejo que não tem outro caminho, que é articulação mesmo, mas que não se dá, então, eu fico pensando nesses momentos, se a gente conseguisse, eu imagino né? O sacrifício que foi conseguir reunir meia dúzia de pessoas , mas eu fico imaginando, então, esse é um desafio grande porque também a instituição faz com que fiquemos muito separados, então, estas questões, elas não conseguem aparecer, eu mal encontro um chegando e outro saindo da sala.. .Para mim, o grande desafio hoje é você tentar buscar esta articulação, que não é ingênua, mas que tem quer ser solidária, se não você não transforma e, só vai dando uma maquiada e, quando vai ver ela está de volta, não tem jeito. (Rosa)

Com relação ao futuro, dadas às contínuas transformações pelas quais as instituições de ensino passam na atualidade, ligadas à flexibilização das relações 
de trabalho e modificações estruturais na política da educação, há grandes preocupações, gerando incertezas e dúvidas, retratadas em algumas falas:

No futuro.. olha vocês me desculpem falar, mas meu futuro é um futuro muito próximo. O futuro próximo, não sei, eu gosto disso aqui gente \{aponta para a trajetória\}. Eu tenho dificuldade de me desligar, acho que eu vou empurrando um pouco mais. Sabe o que acontece? Eu acho que tudo isso aqui é muito bom, até no presente. Nós produzimos coisas muito importantes, muito além do nosso tempo \{choro\}. Nós estávamos à frente da nossa época. Então, isso \{apontando para a trajetória\} é presente. Quando as pessoas estão pensando no presente, falo: gente, mas isso a gente já pensava lá atrás! A Miosótis já pinicava a gente, a gente já pensava isso. Eu olho e falo: meu Deus! Está tudo tão atual, esse passado e é isso que eu quero \{indicando as representações nas cartolinas\}. Porque o presente que se coloca aí, não é o presente que eu quero, não é o futuro que eu quero, sem perder isso aqui \{novamente indicando as cartolinas\}. Nós produzimos muito, é uma sensação que eu tenho. (Estrelitza)

Exatamente, uma coisa que tem me martelado muito no presente, porque isso aqui \{refere-se à representação nas cartolinas\}, o futuro, depende muito disso aqui \{refere-se ao presente\} e isso aqui \{futuro\} para mim, no meu caso, está turbulento, está caótico, está confuso... aí, não dá para pensar só a docência porque eu não sou só a docência, eu sou inteira e a pessoa que eu sou e que foi acompanhando, marcando a minha docência não descolou. Evidentemente tem coisas que eu posso até quando aparece aqui, questões de técnicas, estratégias, não é nesse sentido acho; parece que o conceito que vocês querem montar, que foi falado, ela é construída na vida, nas relações, não nos cursos; os cursos é uma outra forma, auxilia, mas não resolve. Não que eu seja contrária percebe? Acho que aquelas saídas: dar tiro para todo lado, não faz das pessoas bons professores; os cursos, os certificados que eles dão pedagogicamente. A docência se resolve nessa construção \{indica as cartolinas\} de vida que é também saber pedagógico. No problema que acontece daqui para frente, é porque houve momentos em que eu achava de forma atrevida que a gente podia mais do que pode, então, nessa fase para mim, de vida docente profissional que se aproxima de um desinvestimento como é chamado na literatura, não é? A fase de vocês é essa. Eu estou pensando, bom, como é que vai ser esse desenvolvimento, como é que você sai dessa cena, como é que você vai levar para o bastidor, mas não é assim... amargo. Como é que você vai olhar isso? O que é que eu preciso para olhar isso \{refere-se às cartolinas\}, sem me incomodar, daquilo que eu não consigo fazer, sabe? Perceber; esse foi o meu começo, porque eu vim primeiro. Agora o meu receio, que está aqui comigo, está muito marcado pelo lugar onde eu trabalho; isso me incomoda. (Miosótis)

Nesta direção, é entendido pelas participantes do grupo focal que a formação pretendida por elas, no curso de graduação, vai além do desempenho adequado de determinadas tarefas ou atividades, e que consideram um empobrecimento, assumir o caminho que, a curto e, sobretudo a médio e longo prazo, limitaria as possibilidades de colocação, do ex-aluno no mercado de trabalho, fato este perigoso e irresponsável para com as pessoas e a própria sociedade.

Pelo contrário, a formação profissional pretendida é mais aberta e dialógica e ao mesmo tempo crítica; mais flexível e ao mesmo tempo mais rigorosa; solidamente alicerçada em conhecimentos e principalmente, fundamentada na ética, voltada para o desenvolvimento do raciocínio, da autonomia, da criatividade, da comunicação e da capacidade de identificar problemas e buscar alternativas para 
superá-los. Somente assim, consideram as docentes, o estudante estará construindo suas competências e habilidades voltadas para a superação dos conflitos existenciais e éticos, bem como para o enfrentamento dos desafios que a convivência social e o mundo do trabalho apresentarão, no decorrer de sua trajetória de vida.

\begin{abstract}
É marcante a presença de conflitos existenciais profissionais provocados pela não confluência dos referenciais filosóficos e pragmáticos construídos durante a formação circunscritos à inter-ação com aqueles requeridos pelo mercado de trabalho mais pertinentes à intervenção. Os egressos dos cursos de enfermagem nutrem o ideal de se realizarem no modo-de-ser-cuidado, enquanto a grande maioria das instituições hospitalares estão modeladas no modo-de-ser-trabalho privilegiando a intervenção, a produção e a dominação. (FERRAZ, 2000, p.93)
\end{abstract}

Segundo Coêlho (1998), ao ensino de graduação compete o questionamento e rompimento com todo e qualquer moralismo, superando a "ética" das aparências, do momento, das circunstâncias, dos interesses, dos valores e conveniências de indivíduos, grupos e corporações, que é inseparável dos desmandos, da prepotência, da dominação, da exclusão sócio-econômica-política e cultural, que subverte e rompe com os princípios fundamentais na existência individual e coletiva e no exercício profissional: a verdadeira ética.

\begin{abstract}
A ética, pelo contrário, expressão da verdade, do bem, da liberdade, da autonomia, de valores e necessidades humanas universais, transcendentes e permanentes - é um chamamento à superação da prepotência, do legalismo, do moralismo, e à construção da utopia de uma sociedade completamente diferente. (COÊLHO, 1998,.p.5)
\end{abstract}

\title{
6.2.4 - Os determinantes singulares
}

A dimensão singular compreende, neste estudo, as competências docentes construídas ao longo das trajetórias históricas de formação dos docentes, tendo como eixos norteadores as relações interpessoais e a aquisição de conhecimentos que possibilitaram e possibilitam, aos professores, sua ação pedagógica. Ao longo dessa trajetória, os embates que ocorreram nessa dimensão caracterizaram momentos significativos no desenvolvimento das funções docentes, em especial com relação às suas competências.

Nesta categoria estão presentes muitos fatores intervenientes no processo de construção das competências docentes, as quais, segundo Cunha (2004), resultam da idealização de um papel socialmente localizado. 
Segundo a autora,

A idéia de competência é localizada no tempo e no espaço. Mesmo que não de forma expressa, há uma concepção de professor competente feita pela sociedade e, mais precisamente, pela comunidade escolar. Ela é fruto do jogo de expectativas e das práticas que se aceita como melhores para a escola do nosso tempo. (CUNHA, 2004, p.89)

As sociedades industrializadas modernas, após o impacto causado pela superação do paradigma taylorista-fordista, passaram por rápidas, contínuas e profundas transformações sócio-econômicas, culturais e tecnológicas, gerando reflexos nas estruturas dos sistemas educacionais, entre as quais, destaca-se a transformação do ensino de elite, anteriormente praticado, para a educação em massa. Esta, por sua vez, produz grandes modificações sociais que repercutem no estabelecimento de novas formas de organização do trabalho, além de outras mudanças imprevisíveis, por um lado, acabando com campos tradicionais de atuação profissional e por outro, dando origem a áreas novas.

Pode-se afirmar que nesta nova conformação social, nenhuma profissão está imune às mudanças, que certamente, afetam diretamente a existência das pessoas, grupos e instituições, podendo gerar em muitos casos, sua obsolescência. No caso dos professores, os reflexos destas transformações foram significativos para sua prática docente, na medida em que a situação atual difere em muito, daquela vivenciada em sua formação, pois,

A passagem de um sistema de ensino de elite para um sistema de educação em massa implica em um aumento quantitativo de professores e alunos, mas também o aparecimento de novos problemas qualitativos, que exigem uma reflexão profunda. Ensinar, hoje, é diferente do que era há vinte anos. (ESTEVE, 1995, p.86)

As similaridades entre as trajetórias profissionais das entrevistadas foram muitas, na medida em que constata-se que iniciaram suas atividades docentes já no ambiente universitário, sem qualquer preparação específica, tornando a construção das competências docentes o resultado da superação de medos e inseguranças, a partir de reflexões e atitudes eminentemente individuais. Esta superação implicou também no estabelecimento de articulações, ampliação das relações interpessoais e no rompimento com o modelo reprodutivista vivenciado anteriormente, na busca de novas conformações do processo ensino-aprendizagem, como explicitado nas falas seguintes (com grifos nossos),

Eu estava aqui escolhendo um retalho e assim: começar a dar aula sempre foi o quê sempre quis, era o que me excitava profundamente, eu não tinha medo não! Eu queria fazer laços \{pausa\} fazer laços, não imaginava como. Era legal naquela época quando 
comecei aqui, porque acho que ninguém sabia direito como é que era, talvez como a Lírio falou, mas eu cheguei onde queria. (Miosótis)

No meu caso, tenho dois momentos de docência: um começa na graduação quando eu era monitora e que naquela época a gente tinha uma responsabilidade que é muito diferente de hoje, antes, a gente dava aula. Você imagina, eu com 19 anos, dando aula para uma sala de alunos da graduação? Nossa! Hoje, eu fico imaginando o que foi esse momento, a gente não tinha a menor noção do que se sabe hoje. Depois, quando eu vim para cá, que era uma coisa que eu queria sim, era algo muito escuro, eu não sabia e nem queria repetir aquilo que vivi aqui. Então docência era assim, tem luz aqui, mas eu não enxergo \{aponta para um retalho preto\}, eu não estava preparada, não tinha embasamento para fazer aquilo que eu achava certo, não me sentia segura. (Violeta)

Eu queria colocar o que significa isso para mim. Eu vejo que quando se começa a atividade docente, é tudo muito pequeno, você é pequena e com o tempo, você vai crescendo, você vai construindo. É um fio só, é uma coisa que você vai trilhando, você vai juntando e vai evoluindo. Quando você inicia, esse caminho é muito estreito e com o tempo vai se abrindo, vai se alargando. No início é estreito e meio preto mesmo, você nem sabe para onde ir. Isto tem muito significado. (Lírio)

Eu acho que pegando o caminho que a Lírio falou da união, muito do que a Estrelitza e o Miosótis acabou falando, eu acho que esses laços talvez eu usasse a expressão, porque eu ia usar a articulação, mas o laço, ele fica mais solidário. Acho que para criar esses laços, não existe forma ingênua; nós vamos ter que pensar em articulação que é de outra ordem, que é política. Política no sentido das relações e acho que até por conta desse desenvolvimento de competência política que parece importante não só para ter, mas como nesses espaços que você tem autonomia na sala de aula e tudo mais, que você consegue fazer. Agora, eu acho que até a gente não aprofundou, mas tentou iniciar uma reflexão de âmbito maior, de fazer eu acho que não é ingênuo, tem que ser político, mas ele tem que carregar essa coisa solidária, de estar fazendo, para você de fato fazer a transformação porque se você pegar o político, no meu entendimento, é só aplicar para fazer valer alguma coisa que a gente acredita, mas, se não for verdadeiramente solidário, a ponto de acreditar no outro e nas outras coisas, você também não vai conseguir transformar, a gente só vai viver períodos de menor possibilidade, daí eu fico imaginando, o que a gente fica esperando? (Rosa)

Estas colocações vão ao encontro das afirmações de Nóvoa (2001), para quem a formação é algo que pertence ao próprio sujeito e se inscreve num processo de "ser" (nossas vidas e experiências, nosso passado, etc.) e num processo de "ir-sendo" (nossos projetos, nossa idéia de futuro), observando que como Paulo Freire afirmava, ela nunca se dá por mera acumulação. A formação pode ser entendida, em suas palavras, como uma conquista feita com muitas ajudas: dos mestres, dos livros, das aulas, dos computadores. "Mas depende sempre de um trabalho pessoal. Ninguém forma ninguém. Cada um forma-se a si próprio".

Com relação ao lócus específico, vê-se que as relações interpessoais estabelecidas pelo docente com os alunos, fazem com que, em função das especificidades, do trabalho docente, mais do que conhecimentos técnicos na área de formação, o professor propicia aos estudantes as condições de refletir sobre valo- 
res sociais de alta significação que englobam a cultura, a tradição, novas estruturas e formas de pensamentos e visões de mundo, que ao serem mediadas no bojo do fenômeno educacional, atuam e retroatuam sobre todos os seus integrantes, inclusive nele, o professor (Bartolomei, 2004, p. 29).

O professor, por permanecer imerso no processo de ensinoaprendizagem, de certa forma se comporta também, como sujeito e objeto de sua própria ação, principalmente a partir da sua competência reflexiva. Ademais, continua o autor, o professor participa também da formação do "projeto de vida" ${ }^{4}$ de seus educandos, uma vez que há um horizonte maior na pessoa e nas atividades do professor.

A prática e os saberes que podem ser observados no professor é resultado da apropriação que ele fez da prática e dos saberes históricosociais. A apropriação é uma ação recíproca entre os sujeitos e os diversos âmbitos das integrações sociais. Só que elas são diferentes nos sujeitos, isto é, eles se apropriam de diferentes coisas em função de seus interesses, valores, crenças, etc. Isto é demonstrado pelo diferenciamento existente entre o comportamento dos professores que seguem propostas pedagógicas distintas, "refletindo e antecipando sua história". (CU$\mathrm{NHA}, 2004$, p.39)

No entanto, conforme Nimtz (2003), muitas vezes, o profissional se vê em situações embaraçosas, pois é graduado em enfermagem e se vê exercendo as funções de professor. Mesmo sendo excelente enfermeiro, plenamente capacitado técnica e cientificamente, não há garantia alguma que ele seja um bom professor de enfermagem, o que leva a autora a afirmar que "ser professor parece ser algo construído, não simplesmente um dom, vocação, intuição inata; consideramos que para ensinar, também, é preciso aprender a fazê-lo". E, ao se reconhecer despreparado para assumir as funções docentes, face às responsabilidades decorrentes, surgem os medos, as inseguranças, as dificuldades, mas também as lutas e superações:

Eu queria passar uma coisa de medo e até de vergonha, que foi quando dessa coisa minha, acabou sendo de ser a diretora \{da faculdade de enfermagem\}. Porque aí fui me dar conta de que eu podia saber para mim, me achava desafiada, podia errar, acertar, de achar que era um problema meu, dos alunos, eu não tinha a real dimensão. Aí, quando apareceu essa coisa de ter que estar falando, eu sentia vergonha, porque não me sentia preparada, me sentia muito mal e, eu descobri que na verdade, eu não sabia, demorou isso, porque naquele momento não era moda, não tinha uma exigência de capacitação, você aprendia fazendo, mas quando você passa a perceber \{pausa\} Nossa! E agora? Eu me sentia sozinha, perdida, eu tinha medo. (Miosótis)

Nossa! Hoje, eu fico imaginando o que foi esse momento, a gente não tinha a menor noção do que se sabe hoje. Depois, quando eu vim para cá, que era uma coisa que eu

\footnotetext{
${ }^{64}$ Projeto, em uma perspectiva dialética, não é apenas a explicitação de finalidades, mas é também competência para
} ler a realidade, elaborar um plano de ação, colocar em prática e principalmente, avaliar. Cf. Bartolomei (2004, p.29) 
queria sim, era algo muito escuro, eu não sabia e nem queria repetir aquilo que vivi aqui. Então docência era assim, tem luz aqui, mas eu não enxergo \{aponta para um retaIho preto\}, eu não estava preparada, não tinha embasamento para fazer aquilo que eu achava certo, não me sentia segura. (Violeta)

Acho que quando você fez a pergunta facilitadora, da fala da Lírio, quer dizer, de onde vem essas incertezas, as angústias, eu acho que tem um fator muito importante que é a relação trabalho quando ele está institucionalizado e, nós todos somos institucionalizados. Aqui ou acolá e isto tem uma influência muito grande, você estar institucionalizado, porque assim, a vida acontece na relação com o trabalho e, você está dentro de uma instituição. Então acho que até neste momento, em que a Lírio diz desse ir e vir, ela está sendo influenciada no âmbito em que você convive, que é institucional, então, eu acho que até para você sobreviver aqui de maneira geral, quando você bate o olho, embora tenha os momentos mais obscuros e de maior indefinição, predomina a idéia da clareza da vontade do querer, entendeu? Quer dizer, a gente quase que resistindo e, como a Margarida fala, essa coisa da persistência. (Rosa)

Na mesma direção, Cunha (2004, p.37) refere a trajetória histórica e o projeto de vida do docente como fatores influenciadores para sua atividade, pois,

O professor nasceu numa época, num local, numa circunstância que interferem no seu modo de ser e de agir. Suas experiências e sua história são fatores determinantes do seu comportamento cotidiano. Além disso, ele divide o seu tempo em função do seu projeto de vida. Ao analisar o cotidiano, estará se fazendo um estudo do momento em que ele está vivendo e esse fato certamente concretizará esse cotidiano.

Nóvoa (2001), mostra que o aprender contínuo é uma atividade essencial para o docente, devendo se concentrar em dois pilares: a própria pessoa do professor, como agente, e a escola, como lugar de crescimento profissional permanente, observando que na atualidade, a educação passa de uma lógica que separava os diferentes tempos de formação, privilegiando claramente a inicial, para outra que percebe esse desenvolvimento como um processo. Em suas palavras, "a formação é um ciclo que abrange a experiência do docente como aluno (educação de base), como aluno-mestre (graduação), como estagiário (práticas de supervisão), como iniciante (nos primeiros anos da profissão) e como titular (formação continuada), e esses momentos, só serão formadores, se forem objeto de um esforço de reflexão permanente". Percebe-se, nesta colocação, uma das faIhas da formação do enfermeiro-docente, pela ausência das práticas de supervisão durante o ciclo de formação.

Nas falas das entrevistadas, foram detectadas colocações relacionando o processo histórico com a trajetória profissional, com a unidade de ensino e com as características pessoais, todas imbricadas na construção das suas competências docentes, demonstrando a complexidade do fenômeno em estudo. Com efeito, a dicotomia entre a formação inicial e a docência, repercutiu em inúmeras difi- 
culdades iniciais do processo de transformação pelo qual passaram, cuja superação, mesmo que parcial, resultou de esforços próprios no sentido da continuidade dos estudos e da interação com os alunos e demais professores, como apresentado:

Não sei, quando eu peguei esse passado \{referindo-se à cartolina\} e trouxe para cá \{refere-se ao presente\} eu era uma enfermeira, bonitinha, magrinha, quando eu vou virando uma docente, eu vou virando com um pouco de cada uma \{aponta para o grupo\}, porque eu vou vendo e ouvindo a Miosótis como diretora empurrando a gente: vamos estudar, vamos, então eu fui aprendendo muito, com um, com outro. Esse grupo era muito forte e fui aprendendo. Hoje, no presente eu sou tudo isso aqui \{aponta para a cartolina\} porque eu gosto de ser o que as pessoas me ensinaram a passar a ser. Eu não busquei uma capacitação formal. Hoje, não me acho "a" professora, nem quero mais ser o docinho. (Estrelitza)

Eu estava refletindo esses dias com uma pessoa, que eu vejo que permaneço com essa coisa muito mesclada até porque, do passado até o presente, essa busca de aprimoramento, a oportunidade que surgiu aqui, mas, eu queria acrescer esse daqui \{mostrando outro tecido\} por que assim, apesar de todas as dificuldades, eu preciso encontrar o prazer, senão não estou na minha, e, no trabalho que a gente vive tanto tempo e aí, para representar essa coisa de satisfação de felicidade, eu escolhi essa cor amarela, que eu gosto muito. Então quis carregar isso porque para mim tem a representação mesmo, que embora todos os empecilhos, porque eu acho assim, ai talvez entre como a Estrelitza falou, pega todo o passado com percalços e tudo, mas eu sinto que não consigo perder essa mescla de busca e essa felicidade, senão não estava aqui, porque eu preciso dessa felicidade desse prazer pra viver mesmo. Eu não vou por lá \{referindo-se à cartolina do passado\}, mas vou por assim percorrendo \{dispondo o tecido entre as cartolinas do passado e do presente\}, porque é assim que está acontecendo. (Rosa)

Exatamente, uma coisa que tem me martelado muito no presente, porque isso aqui \{refere-se à representação nas cartolinas\}, futuro, depende muito disso aqui \{refere-se ao presente\} e isso aqui \{futuro\} para mim, no meu caso, está turbulento, está caótico, ta confuso, aí, não dá para pensar só a docência porque eu não sou só a docência, eu sou inteira e a pessoa que eu sou e que foi acompanhando, marcando a minha docência não descolou. Evidentemente tem coisas que eu posso até quando aparece aqui, questões de técnicas, estratégias, não é nesse sentido acho; parece que o conceito que vocês querem montar, que foi falado, ela é construída na vida, nas relações, não nos cursos; os cursos é uma outra forma, auxilia, mas não resolve. Não que eu seja contrária percebe? Acho que aquelas saídas: dar tiro para todo lado, não faz das pessoas bons professores; os cursos, os certificados que eles dão pedagogicamente. A docência se resolve nessa construção \{indica as cartolinas\} de vida que é também saber pedagógico. (Miosótis)

As responsabilidades assumidas pelas enfermeiras ao se dedicarem à docência são reconhecidas e valoradas pelas entrevistadas, demonstrando a capacidade crítico-reflexiva assumida no decorrer de suas trajetórias, na medida em que, partindo de uma formação tecnicista por excelência, baseada no modelo flexneriano adotado por muito tempo no país e ainda hegemônico, se viram inseridas em um novo e complexo ambiente relacional, representado pelo trabalho pedagógico na saúde, principalmente nas atividades práticas e de estágios super- 
visionados, com novas tarefas e desafios, especialmente com relação aos problemas éticos do cuidar. ${ }^{65}$

Conforme Merhy (1997), todos os profissionais de saúde, independentemente dos papeis desempenhados, inclusive o de enfermeiro-professor, atua sobre a complexidade do 'caso' concreto que se depara. Neste sentido, atua ao mesmo tempo como operador do cuidado e como administrador das relações entre os diversos núcleos de saberes profissionais presentes na intervenção em curso, ocupando o papel de mediador da gestão dos processos multiprofissionais e disciplinares que permitem o agir em saúde. Diante disso, entende-se o porquê dos muitos conflitos, bem como das posições assumidas pelas entrevistadas com relação à formação dos estudantes de enfermagem, quando dizem:

Voltar a um período de possibilidade, tentar ajudar ou a gente pode ter ações e verdadeiramente tentar ajudar a transformar e transformar o outro mesmo porque eu não acho que o outro é impossivel de ser transformado. Então eu vejo que não tem outro caminho, que é articulação mesmo, mas que não se dá, então, eu fico pensando nesses momentos, se a gente conseguisse, eu imagino né? Facilitadora, o sacrifício que foi conseguir reunir.. .meia dúzia de pessoas, mas eu fico imaginando, então, esse é um desafio grande porque também a instituição faz com que fiquemos muito separados, então, estas questões, elas não conseguem aparecer, eu mal encontro um chegando e outro saindo da sala...Para mim, o grande desafio hoje é você tentar buscar esta articulação, que não é ingênua, mas que tem quer ser solidária, se não você não transforma e, só vai dando uma maquiada e, quando vai ver ela está de volta, não tem jeito. (Rosa)

Eu fico pensando não é? Estrelitza, que pode estar, porque, por exemplo, quando você está aí \{refere-se ao campo de estágio na saúde pública\} que é a hora que você pode estar na sala de aula, ou aí ou um outro espaço, numa relação muito boa, de independência, possivelmente de autonomia com o aluno, não nesse sentido "aluno", mas daquele que virá a ser, que vai ocupar os espaços futuros e que você tenha nesse amadurecimento nessas coisas que você já viu e aí eu concordo com você, é o grande momento que se dá a docência sabe? Porque aí você está mesmo lógico, ainda institucionalizado, mas talvez essa tua fala seja bastante expressiva; você consegue se descapturar. (Rosa)

É verdade, eu me sinto mais professora quando estou atuando do que quando estou em sala de aula. Essa diferença de contextos, espaciais, territoriais, que para mim tem um significado também. (Estrelitza)

Até por que você está numa relação com o aluno lá, numa coisa que é real, que é concreta, que você pode ou não, daí dependendo da sua ação, transformar. (Rosa)

\footnotetext{
${ }^{65}$ Até a Constituição de 1988, quando, por força legal, foi prescrito o novo modelo denominado Sistema Único de Saúde, o modelo clínico/biológicolflexneriano era adotado oficialmente como paradigma da saúde. Este modelo consolidou-se em virtude das recomendações apontadas por Abraham Flexner (1866-1959) em relatório encomendado pela Fundação Carnegie dos Estados Unidos, em 1910 (Novaes, 1990), cujas conclusões tiveram amplo impacto na formação médica em quase todo continente americano, expandindo-se pelos demais a partir de recomendações dos órgãos de fomento e financiamento para os países em desenvolvimento. 0 modelo flexneriano, baseado num paradigma fundamentalmente biológico e quase mecanicista para a interpretação dos fenômenos vitais, gerou, entre outras coisas, o culto à doença e não à saúde, e a devoção à tecnologia, sob a presunção ilusória de que seria o centro de atividade científica e de assistência à saúde.
} 
Quando você estava falando isso (refere-se à Estrelitza) eu estava pensando exatamente isso, porque a hora que eu sinto meu melhor momento de docência com a competência docente, é esta fase, no corredor, sentada com o aluno fora daquela... do formal, porque a classe é aquela coisa meio teatral, com um monte de aluno em que um sai outro entra um presta atenção outro não, aquela coisa. Mas no momento em que você está com eles ali, meia dúzia de alunos, é outra coisa. (Violeta)

Considerando competência como uma complexa atividade mental e intelectual que reúne a capacidade e a habilidade do indivíduo em mobilizar conhecimentos e recursos mentais para resolver situações complexas que ocorrem em sua vida cotidiana ou profissional (Perrenoud, 2000), é essencial para a docência, ou mesmo a essência da docência, na medida em que estas operações mentais são realizadas em tempo real, isto é, a mobilização dos atributos, conhecimentos, vivências e recursos mentais, tem de ser efetuada, instantaneamente, no momento da solicitação.

Por outro lado, a educação em enfermagem é um processo pedagógico de interação com a realidade do ambiente de saúde, imerso em inúmeras relações interpessoais, baseado no trabalho com o conhecimento e realizado sob a mediação do professor-enfermeiro. Com a finalidade de colaborar com a formação do profissional do egresso em sua totalidade, o docente, a partir e com a utilização de suas competências, busca proporcionar condições que possibilitem a produção do sentido ético do cuidar.

Conforme as falas das entrevistadas, inferimos as competências construídas ligadas aos aspectos relacionais, bem como voltadas para a construção coletiva de conhecimentos e saberes, de ética do cuidado e respeito às diferenças, munidas da intencionalidade de transformação social, assim se referindo:

Eu acho talvez, que a gente pudesse pegar essa coisa da intencionalidade, porque não há ingenuidade eu acho, essa coisa você vai tocando aqui, não é tocar que nem barata tonta, tem uma intencionalidade nas coisas que a gente faz; se a gente quer recuperar a essência do passado, por exemplo, a gente pode reeditar as questões exatamente como foi, mas as idéias estão presentes como que intencionalmente ajuda na formação dessas outras pessoas, na construção coletiva dessa docência, que se dá na prática do cotidiano. Eu acho que talvez, usando de estratégias com temas e tudo mais, o coletivo pode facilitar, agrupando pessoas e criando essa cultura da gente fazer isso e ir pensando a docência, nossa prática e tudo mais. (Estrelitza)

Eu vou continuar empurrando daqui \{apontando para o passado\}. Não sei se quero me desenvolver mais, não tenho clareza disso; tive alguns momentos formais que a instituição promoveu, você vai captando, mas não consegui me sentir... plena de competência. Não é isso, mas não sei se há alguma competência, não sei dizer isso. Eu acho que sou boa professora, curto o que faço, adoro dar aula, mas eu não sinto formalismo nisso. 0 desenvolvimento das minhas competências, não se deu de forma formal, mas também não se deu de forma anárquica. Não foi!! (Estrelitza) 
Quando houve a entrevista eu peguei meu percurso desde o técnico, passando pela experiência como enfermeira em uma unidade de internação, com um momento rico de compartilhar com alunos, professores e também num momento de explodir mesmo, em conhecimento e veio mesmo a chance oficial, concreta, então, para mim também foi muito bom poder iniciar e colocar em prática tudo aquilo que eu já acreditava e que vinha da minha experiência do hospital universitário. (Rosa)

Eu continuo com a busca da capacitação, eu estou me capacitando, apesar de algumas inseguranças e o azul representa tranqülilidade de perspectivas e o grupo se ajudando, se comunicando. (Margarida)

Diante do caráter polissêmico do conceito e da diversidade de autores, bem como das falas captadas e processadas a partir das categorias analíticas e empíricas que emergiram das análises na presente pesquisa, entende-se que as competências docentes se apresentam em três dimensões:

> competência técnico-científica, relacionada ao domínio dos saberes, conhecimentos técnicos e científicos necessários para a realização eficiente e profissional das tarefas na área da enfermagem;

> competência sócio-educativa, relacionada à capacidade pedagógica intrínseca às atividades docentes e profissionais, envolvendo a retroatuação para superação de questões e desvios surgidos, descobrindo, autonomamente, as vias de solução, transferindo de forma sensata as experiências colhidas para outros problemas de trabalho, com amplo aspecto social e coletivo, e

> competência ético-social, que envolve a colaboração e cooperação com outras pessoas - estudantes, usuários, docentes e demais profissionais, referindo as relações humanas de forma participativa e construtiva, assumindo as responsabilidades de transformador social preconizadas para o desempenho profissional, com observação à ética e com respeito à autonomia, diversidade e responsabilidade. 



\section{VII - ALGUMAS CONCLUSÕES E NOVOS CAMINHOS}

Os professores encontram-se, hoje, perante vários paradoxos. Por um lado, são olhados com desconfiança, acusados de serem profissionais medíocres e de terem uma formação deficiente; por outro lado, são bombardeados com uma retórica cada vez mais abundante que os considera elementos essenciais para a melhoria da qualidade do ensino e para o progresso social e cultural. PedeIhes quase tudo. Dá-se-Ihes quase nada. (Nóvoa, 1998, p.34)

A presente pesquisa, começa com a formulação de três hipóteses representadas por afirmações provisórias, mantidas subjacentes ao longo da pesquisa, compondo as balizas fronteiriças do caminho percorrido, auxiliando no confronto do referencial teórico com a realidade empírica captada visando atingir os objetivos específicos da pesquisa. Como toda hipótese, por se tratar de uma teoria, provável, mas, ainda não demonstrada, eram suposições admissíveis, no imaginário da pesquisadora.

A realidade empírica pesquisada, analisada à luz dos determinantes históricos, reproduz o mesmo processo histórico da educação ao longo do tempo. Assim, esse processo é referendado na historicidade da vida de cada sujeito da pesquisa, de forma semelhante à trajetória da educação nas sociedades nos seus diferentes momentos. Historicamente, a sociedade influencia e/ou determina ain$\mathrm{da}$, quem é o professor, quais as qualidades requeridas, quais os valores da sociedade a ele demandados e que são reconhecidos como válidos e qual a formação desses professores.

A primeira hipótese formulada foi que o perfil atual do professor enfatiza as qualidades pessoais que invadem a construção das competências docentes. Essa hipótese é confirmada, tanto no processo histórico, como resgatado na trajetória de vida profissional dos sujeitos da pesquisa. 
Com efeito, na Antiguidade, os professores iniciam sua trajetória sendo menosprezados, além de serem considerados subservientes e não possuírem qualquer qualificação ou formação específica, ou seja, não eram exigidas quaisquer competências para o ofício, que, aliás, nem sequer era reconhecido no mundo civilizado de então, com poucas exceções. Posteriormente, já na Idade Média, houve o resgate das qualidades morais do professor como condição necessária para o exercício destas funções, uma vez que a educação se achava sob a tutela da Igreja Católica, responsável pela expansão do ensino jesuítico pelas nações e pelos territórios colonizados. A partir de então, as características pessoais mantiveram-se valorizadas pelas sociedades no tocante à pessoa do educador, ao longo de todas as transformações pelas quais a educação atravessou na sua história.

No mesmo sentido, as falas das entrevistadas igualmente confirmam esta hipótese, na medida em que revelam serem as qualidades pessoais os elementos intrínsecos e geradores da construção das competências docentes, possibilitando a mobilização dos seus valores, suas crenças e características pessoais para a docência, assim exemplificadas:

Começar a dar aula sempre foi o quê sempre quis, era o que me excitava profundamente, eu não tinha medo não! Eu queria fazer laços \{pausa\} fazer laços, não imaginava como. Era legal naquela época quando comecei aqui, porque acho que ninguém sabia direito como é que era, mas eu cheguei onde queria. (Miosótis)

Para mim também foi muito bom poder iniciar e colocar em prática tudo aquilo que eu já acreditava. (Rosa)

A segunda hipótese, "o perfil do professor sofre influência dos valores vigentes na sociedade", considera que os valores imanentes na sociedade na qual ele se acha inserido e realizou sua formação, representariam um fator determinante para a construção de suas competências docentes. Esta hipótese também foi confirmada, tanto histórica quanto empiricamente.

Desde a Antiguidade, quando a função do professor sequer era reconhecida pela sociedade, passando pelo Império Romano, que iniciou o uso da educação como forma de expansão e solidificação de sua dominação física e ideológica pelos territórios conquistados, seguindo até a Idade Média, quando por meio da Ratio Atque Studiorum, os mestres passaram a ser escolhidos pela Igreja Católi$\mathrm{ca}$, que igualmente se utilizou da educação como forma de dominação política, econômica e ideológica, chegando até a atualidade, as forças políticas hegemôni- 
cas das sociedades foram responsáveis pela conformação da educação e, por conseguinte, da formação dos professores.

Esta trajetória demonstra que a sociedade produziu a idéia do professorsacerdote, ao considerar suas atividades como uma missão, à semelhança da dos religiosos, observando-se que esta mistificação foi um produto social, que causou interferências no seu modo de ser e de agir. Posteriormente, evoluiu a idéia do professor como profissional liberal, quando foi privilegiado o seu saber específico e foi atribuída a ele uma independência que, efetivamente, talvez nunca tenha existido. Mesmo nos países desenvolvidos, os professores são vistos como os "proletários das profissões liberais", proletarização essa que se acentua em países em desenvolvimento, inclusive no Brasil. Neste contexto, o professor é considerado um trabalhador assalariado que vende o produto de seu trabalho, mas, como o mundo capitalista tende a "comprar" a produção intelectual que the interessa, estará novamente interferindo no perfil dos profissionais da educação.

A influência representada pela sociedade também foi confirmada pelas professoras entrevistadas com relação à construção de suas competências docentes, em razão de suas vivências pessoais, das experiências acumuladas, dos conflitos e das relações interpessoais, como o exemplo:

Tem uma coisa na docência que ela é além do que o conhecimento pode trazer, ela passa por outra dimensão que também não sei dizer qual é... dessa interação, desse posicionamento em sala, dessa relação com o conhecimento, com momentos de tolerância com momentos de exigências, eu acho que é uma coisa para ser vivida mesmo, não sei se existe um modelo, não sei se existe uma pré-determinação, porque a gente acaba também vivendo a docência com muita ressonância daquilo que a gente está naquele dia, porque nós somos gente como qualquer outro, que tem dificuldades, alegrias, amores e dissabores, como qualquer outro e que, em algum momento, interfere numa aula melhor. (E-02)

Os conflitos presentes na carreira docente são muitos e multifacetados, mas a principal dificuldade encontrada diz respeito às diferenças intrínsecas das funções, pois, mesmo sendo um bom profissional de enfermagem, dotado de conhecimentos e competências específicas para sua área de formação, muitas vezes se conhece como incapacitado para a área de ensino. Não há garantias, há conflitos e dúvidas. Ser professor é mais do que ser um bom profissional na sua área: resulta de uma construção de competências diversificadas que permitirão o desenvolvimento da capacidade de intervenção pelo conhecimento de forma a transformar a realidade almejada pela sociedade, pelos alunos e pelo docente.

Existe algo na nossa profissão que ajuda muito na docência, nós temos uma vivência prática e esta vivência possibilita transitar entre a teoria e a prática e fazer estas liga- 
ções, e a prática alimenta teoria e alimenta aqueles exemplos e aquelas vivências e eu acho isso muito bom e ao contar essa vivência para os alunos, trazê-las com as emoções vividas e não apenas como mais um episódio que aconteceu na vida da gente como enfermeiro, mas, quais foram os sentimentos, as sensações, as dificuldades vividas naquele momento, e acho que isso faz com haja uma aproximação nesse momento do aluno quando ele pode olhar para a gente e falar assim: ela já cresceu e também tem dificuldade, ela já andou alguns quilômetros rodados e ela também tem medos, ela já se aprimorou formalmente com títulos e etc e também se vê em situações difíceis. (E-02)

Neste sentido, estas relações ensejaram o desenvolvimento de competências da esfera sócio-educativa, ligadas às atividades pedagógicas intrínsecas dos docentes, envolvendo a comunicação, autonomia intelectual, capacidade auto-reflexiva e de autocrítica, que possibilitam a retroatuação para superação de questões e conflitos, descobrindo, autonomamente, as vias de solução, viabilizando a adoção de experiências anteriores para solucionar problemas de trabaIho, com amplo aspecto social e coletivo.

A hipótese final pressupõe que as estruturas das Instituições de Ensino Superior (IES) influenciam e determinam a trajetória e a capacitação profissional do docente. Esta hipótese também foi confirmada, tanto histórica quanto empiricamente. A universidade e os cursos graduação estão intimamente ligados aos processos sociais mais amplos de produção e reprodução da existência individual e coletiva, da utopia e do desejo da boa sociedade. O sentido da graduação, como apreendido pelas docentes, sujeitos desta pesquisa, não se situa, pois, apenas no plano legal, burocrático e cartorial. Conforme suas colocações, não bastam apenas profissionalizar e diplomar os alunos, muito menos apenas treiná-los para depois, inseri-los no mundo do trabalho. Para mera formação profissional e transmissão de conhecimentos avançados na esfera das ciências e da tecnologia, não haveria a necessidade da universidade e da graduação.

Assim, a influência da unidade de ensino proporcionou, historicamente, o desenvolvimento também de competências técnico-científicas, estas relacionadas à aquisição, construção e domínio dos saberes e conhecimentos técnicos e científicos, necessários para a realização eficiente e profissional das tarefas nas áreas da enfermagem e do ensino em enfermagem.

Diante dos conceitos levantados e das falas captadas, tanto nos momentos das entrevistas quanto na fase do grupo focal, constata-se que, quanto ao primeiro objetivo da pesquisa, as competências docentes não foram construídas em um momento temporal específico, mas sim, ao longo das trajetórias pessoais e profissionais. Em outras palavras, as competências são construídas e reconstru- 
ídas no cotidiano geral das profissionais, expandido para além da sua área técnica de formação, invadindo os espaços sociais das relações interpessoais, tanto na sociedade, quanto nas instituições de ensino.

E como são construídas? Como o professor nasce e está imerso em seu cotidiano historicamente vivenciado, constrói suas competências acionando seus mecanismos pessoais, trabalhando com conhecimentos já existentes e buscando interagir com as normas e regras vigentes na sociedade no momento em que está vivendo. Na mesma direção, as enfermeiras-professoras reconhecem em suas falas, de forma até contundente, que em decorrência do despreparo pedagógico, a fase inicial da docência ocorreu em um contexto eminentemente reprodutivista, recorrendo a modelos vivenciados com professores em seu próprio curso de graduação e que, de alguma forma, provocaram "marcas" sociais em suas trajetórias.

Portanto, o processo de construção das competências docentes deu-se, e se dá, em determinados momentos da trajetória histórica dos professores, de forma tradicional e positivista, baseada na reprodução dos saberes de outros professores. No entanto, no momento em que se sentiram incomodadas com esta situação, quer pelas colocações dos alunos, mas em sua maioria, pela autocrítica, reconhecendo-se desprovidas das competências necessárias para superar as deficiências e conflitos pessoais, todas as entrevistadas recorreram à aquisição de novas habilidades, novos saberes, novos relacionamentos com os demais professores, no sentido de estabelecer uma nova relação pedagógica.

Assim, a construção das competências docentes se dá ao longo de um processo de contínua capacitação do profissional, voltado para a construção do seu perfil enquanto profissional de enfermagem ligado à docência, perfil este que está em constante transformação pela aquisição de novos conhecimentos e competências necessárias para sua atividade profissional.

Ao identificar os conhecimentos e habilidades que foram desenvolvidas na construção de competências para o ensino de Enfermagem, as falas captadas mostraram grande sintonia na direção de um conjunto de fatores intervenientes, demonstrando a influência do processo histórico e dos determinantes sociais, que por sua vez, moldam as estruturas das unidades de ensino, estabelecendo as relações com as competências.

No posicionamento dos sujeitos pesquisados, pode-se resgatar que se trata de um conjunto de saberes técnicos e científicos que proporcionaram embasamento em suas ações na esfera da enfermagem, bem como da pedagógica e 
voltados para esta ação, principalmente em cursos de pós-graduação em educação. Com relação às habilidades, foram desenvolvidas as que se referem às relações interpessoais e de interação professor-aluno; de planejamento de ações e de uso de novas estratégias e metodologias de ensino que possibilitaram o aprimoramento da visão educacional e as voltadas para a construção da autonomia intelectual, tanto do aluno quanto do próprio docente.

É relevante que, entre as habilidades e capacitações construídas, tenham sido indicadas, com muita ênfase, aquelas voltadas para a transformação social e para a dimensão ética do cuidado e do saber, demonstrando a grande preocupação das entrevistadas com relação a ética.

Contudo, apenas as competências e habilidades vinculadas ao saberfazer não são suficientes para a ocupação efetiva e qualificada de um espaço profissional, para o alcance da autonomia correspondente e para o reconhecimento profissional em uma dada organização de saúde. As competências relacionadas ao aprender a aprender e ao aprender a ser, aprender relacionar-se e melhor conviver, são essenciais na gestão dos serviços de saúde. (CIAMPONE e KURCGANT, 2005, p.64)

A busca de formas de intervenção nesse processo por meio da reflexão sobre a prática docente, objetivo final desta pesquisa, nos remete em direção ao futuro. Evidentemente, há inúmeras incertezas com relação ao futuro, em decorrência das constantes transformações pelas quais a sociedade e o mundo do trabalho estão passando, e esta sensação emana das falas, de forma clara e objetiva, demonstrando a consciência que as modificações estruturais no mundo globalizado da atualidade, atingem e atingirão a todos nesta sociedade em mutação.

As docentes consideram imperativo o estabelecimento de um novo modo de pensar e de agir no contexto da educação em enfermagem, visando a melhoria no atendimento das demandas sociais, referindo-se à construção das competências ético-sociais, envolvendo a capacidade de colaboração e cooperação com o outro (estudantes, usuários, docentes e demais profissionais), estabelecendo relações humanas participativas e construtivas, assumindo a responsabilidade de ser um agente transformador social sob a égide da ética, especialmente a ética no cuidado, respeitando a autonomia, a diversidade e a responsabilidade nas relações com o outro.

Tendo em vista que essas docentes vivem na sociedade atual, onde a ética das relações interpessoais e das relações de trabalho são colocadas em risco e questionadas a todo o momento, talvez seja, hoje, este o motivo da grande preocupação das docentes. Assim, objetivam a construção de competências e habili- 
dades para poder passar, para os futuros enfermeiros, como eixo norteador fundamental, o sentido ético do ser e do agir, de forma clara, impedindo que seu significado seja apreendido de forma tênue e descompromissada.

Para esta nova conformação do processo de ensino-aprendizagem, é necessário que não só os novos enfermeiros, mas também atuais e futuros enfermeiros-professores, desenvolvam competências que os possibilitem a pensar e agir com ética e ousadia.

Ética e ousadia não se conflitam, mas, ao contrário, produzem qualidade política, que em oposição à qualidade formal (voltada apenas para o aspecto instrumental), é voltada, pensada e dirigida para a qualidade ambiental do ser humano em formação, aquela que vai proporcionar os conceitos fundamentais da construção do conhecimento como elemento de crescimento social, com base na ética social. (BARTOLOMEI, 2002, p.148)

Esta nova forma de pensamento criativo na educação em enfermagem poderá e deverá ser incorporado, não só aos discursos formais, mas também, impregnar totalmente a prática do ensino em todos os níveis, pois

\footnotetext{
É necessário um pensamento que reúna o que está separado e compartimentado, que respeite o diverso sem deixar de reconhecer o uno. (...) Temos que aprender não só a complexidade das inter-retro-atuações, mas também o caráter hologramático que faz com que não só a parte esteja no todo, mas também que o todo esteja no interior da parte. (MORIN e KERN; 1993, p.138)
}

As colocações captadas mostram que o desejado é a formação de um profissional competente, na mesma direção apresentada pelas DCN que regem os cursos de graduação em enfermagem. Mas, o que é o profissional competente? É aquele que, dotado de conhecimentos técnicos e científicos condizentes com sua área de formação, atua sempre com vistas à reflexão pluralista do envolvimento global de sua atuação. Para tanto, age no sentido do estabelecimento ou criação de novas realidades com ética social, experimentando, ousando, corrigindo, inventando e reinventando, dialogicamente com a própria realidade social em que se acha inserido. Além disso, que seja capaz, também, de realizar, novamente nas palavras de Morin, Kern (1.993), uma retroatuação ética, crítica e reflexiva.

O profissional competente actua refletindo na acção, criando uma nova realidade, experimentando, corrigindo e inventando através do diálogo que estabelece com essa mesma realidade. (...) Em conclusão, o profissional reflexivo constrói de forma idiossincrática o seu próprio conhecimento profissional, o qual incorpora e transcende o conhecimento emergente da racionalidade técnica. (GÓMEZ, 1995, p.110) 



\section{REFERÊNCIAS BIBLIOGRÁFICAS}

Anastasiou LG. Ensinar, aprender, apreender e processos de ensinagem. In: Anastasiou, L.G. e Alves, L.P. (org). Processos de ensinagem na universidade: pressupostos de trabalho em aula. Joinville: UNIVILLE, 2003.

Bartolomei R. Ensinando em tempos de incerteza: a re-significação de erro em busca da melhoria da qualidade do ensino. In: Revista de Educação PUC-Campinas. Campinas: n.17, [15-35], nov 2004.

- Pensando o ensino do futuro com perspectivas humanizadoras: a engenharia civil como pretexto. [tese] Faculdade de Educação UNICAMP. Campinas, SP: 2002.

Berger R. Formação baseada em competências numa concepção inovadora para a formação tecnológica. In: Congresso de Educação Tecnológica dos países do Mercosul. 5, Pelotas (RS), ETF-Pel. 1998.

. Currículo e competências. In: Seminário Internacional de Educação Profissional, 1, Brasília; 2000.

Brasil. Ministério da Educação e Cultura. Documento básico do ENEM 2000. Brasília (DF) INEP, 1999.

Ministério da Saúde. Conselho Nacional de Saúde. Resolução oㅡ 196 de10 de Outubro de 1996: Diretrizes e Normas Regulamentadoras de pesquisas em seres humanos. Revista Bioética. 1996; 4:15-25

Ministério da Saúde. Fundação Serviços de Saúde Pública. Enfermagem: legislação e assuntos correlatos. Rio de Janeiro (GB), 3ª ed. vol I. 1974.

Bardin L. Análise de Conteúdo Lisboa: Edições 70, 1977.

Baptista SS , Barreira IA. Docentes e estudantes no processo de mudança do ensino de enfermagem no Brasil. In: Texto\&Contexto-Enfermagem; Florianópolis: UFSC. vol. 8; nำ1 (67-79) jan-abr 1999.

Camargo ALC. O processo de reestruturação da PUCCAMP: a contribuição do "Projeto Pedagógico" (1981-1984). [dissertação] Campinas: Faculdade de Educação da Universidade Estadual de Campinas - UNICAMP; 1989.

Canário R. O educador no olho do furacão. (Palestra) IV Congresso Saber 2000, promovido pelo SIEEESP. São Paulo: SIEEESP. (vídeo) 2000.

Cavaco MH. Ofício do professor e o tempo de mudanças. In: Nóvoa, Antonio (org.) Profissão professor. Porto: Porto Editora; 1995

Ciampone MHT, Kurcgant P. Gerenciamento de conflitos e negociação. In: Kurcgant P. (coord) Gerenciamento em Enfermagem. Rio de Janeiro: Guanabara-Koogan, 2005. 
Coêlho IM. Graduação: rumos e perspectivas. In: Revista Avaliação - Rede de Avaliação Institucional da Educação Superior - RAIES; Campinas: v.3, nํㅜ, set-1998.

Cunha LA. A Universidade Crítica: o ensino superior na república populista. Rio de Janeiro: Editora Francisco Alves; 1989

A Universidade Temporã: da Colônia à era Vargas. $2^{\underline{a}}$ ed. Rio de Janeiro: Editora Francisco Alves; 1986.

Ensino Superior e Universidade no Brasil. In: Lopes EMT, Faria Filho LM, Veiga CG (org) 500 anos de Educação no Brasil. 3르 ed. Belo Horizonte: Autêntica Editora; 2003.

Cunha Ml. O bom professor e sua prática. 16ª ed. Campinas: Papirus; 2004.

Dall'Agnol CM, Trench MH. Grupos focais como estratégias metodológicas em pesquisas na enfermagem. Rev. Gaúcha de Enfermagem 1999; 20(1): 5-25.

Dilthey W. Essência da filosofia. Lisboa: Presença, 1984.

Eby F. História da educação moderna: teoria, organização e práticas educacionais. $2^{\underline{a}}$ ed. Porto Alegre: Editora Globo/MEC; 1976.

Encarnação JB. Que é isto, o Direito? Introdução à filosofia hermenêutica do Direito [snt] disponível no site <http://geocities.yahoo.com.br/paginadehermeneutica/ahistoriadahermeneutica.html (acessado em 08-fev-2006)

Esteve, JM. Mudanças sociais e função docente. In: Nóvoa, A. (org). Profissão Professor. Porto, Portugal: Porto Editora, 1995

Faria JIL. Prática docente reflexiva na disciplina de administração de enfermagem hospitalar: uma experiência de desenvolvimento profissional de professores-pesquisadores. [tese] Ribeirão Preto: Escola de Enfermagem de Ribeirão Preto da USP; 2003.

Fernandes GFM, Vaz MRC. Processo de avaliação humanizado e participativo nos estágios supervisionados de enfermagem. In: Texto\&Contexto-Enfermagem; Florianópolis: UFSC. vol. 8; ㄲo1 (106-121) jan-abr 1999.

Ferraz CA. As dimensões do cuidado em enfermagem: enfoque organizacional. Acta Paulista de Enfermagem, São Paulo: v.13, número especial, parte I, p.91-97, 2000.

Ferreira $\mathrm{ABH}$. Novo dicionário da língua portuguesa. $2^{\mathrm{a}}$ ed. Rio de Janeiro: Nova fronteira; 2001.

Foucault M. Microfísica do poder. 10ª ed. Rio de Janeiro: Graal; 1992.

França LF. O método pedagógico dos jesuítas. Rio de Janeiro: Agir, 1952

Freire P. Pedagogia da Autonomia: saberes necessários à prática educativa. 30ª ed. São Paulo: Editora Paz e Terra; 1996.

Novos tempos, velhos problemas. In: Serbino RV et all (orgs) Formação de Professores. São Paulo: Fundação Editora UNESP; 1998.

1987.

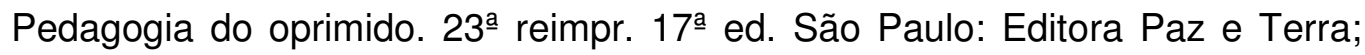

Educação e mudança. Rio de Janeiro: Editora Paz e Terra. 1983.

Gadotti M. História das idéias Pedagógicas. São Paulo:Editora Ática; 1999. 
Geib LTC, Migott AMB, Carvalho RMA, Mocinho RR. Os rituais de poder na educação formal do Enfermeiro. In: Texto\&Contexto-Enfermagem; Florianópolis: UFSC. vol. 8; ㄲo1 (80-92) jan-abr 1999.

Goergen P. O sistema de ensino e a formação de professores na Alemanha. In: Saviani D, Goergen P. (org) Formação de professores: a experiência internacional sob o olhar brasileiro. Campinas: Autores Associados. 1998.

Gómez AIP. As funções sociais da escola: da reprodução à reconstrução crítica do conhecimento e da experiência. In: Sacristán JG, Gómez AIP. Compreender e transformar o ensino. 4를 ed. Porto Alegre: Artmed; 1998.

. "O Pensamento Prático do Professor: A Formação do Professor como Profissional Reflexivo" in Nóvoa A. (org.). Os professores e sua Formação. Lisboa: Publicações D. Quixote, Lda., 1995

Goode WJ, Hatt PK. Métodos em pesquisa social. 3aㅡ ed. São Paulo: Cia Editora Nacional; 1969.

Gualda DMR, Mereghi MAB, Oliveira SMJV. As abordagens qualitativas e sua contribuição na enfermagem. São Paulo: Revista da Escola de Enfermagem da USP. 1995; 29:297-309

Guimarães SER. Motivação intrínseca, extrínseca e o uso de recompensas em sala de aula. In: Borichovitch E, Bzuneck JA (orgs). A motivação do aluno: contribuições da psicologia contemporânea. Petrópolis: Editora Vozes; 2001.

Haguette A. Educação: bico, vocação ou profissão? Educação \& Sociedade, São Paulo, v.12, no. 38, abr. 1991.

Harvey D. Condição Pós-moderna: uma pesquisa sobre as origens da Mudança Cultural. 4를. ed. São Paulo: Edições Loyola; 1994.

Hubert R. História da Pedagogia. $2^{\underline{a}}$ ed. São Paulo: Companhia Editora Nacional; 1967.

Ianni O. O cidadão do mundo In: Lombardi JC, Saviani D, Sanfelice JL (org) Capitalismo, trabalho e educação. Campinas: Autores Associados; 2002.

Larrousse. Enciclopédia Larrousse Cultural 98. Folha de São Paulo e Nova Cultural. São Paulo, 1998.

Lima MADS. Ensino de enfermagem: retrospectiva, situação atual e perspectivas. Revista Brasileira de Enfermagem 1994; 47(270 -7)

Lima LO. Estórias da Educação no Brasil: de Pombal à Passarinho. $2^{\underline{a}}$ ed. Rio de Janeiro: Editora Brasília; [197?].

Lüdke M, Moreira AFB, Cunha MI. Repercussões de tendências internacionais sobre a formação de nossos professores. Educação \& Sociedade, Campinas, SP, n. 68, p.278298; 1999.

Luzuriaga L. História da Educação e da Pedagogia. 4⿳a ed. Editorial Lousada: Buenos Aires;1969.

Marrou H. História da Educação na Antiguidade. 4ํㅜㄹ reimpr. São Paulo: Editora Pedagógica e Universitária; 1975.

Merhy EE. Em busca do tempo perdido: a micropolítica do trabalho vivo em saúde. In Merhy EE, Onoko R. (org.) Agir em saúde. São Paulo, (SP) Hucitec, 1997. (p.74-111).

Minayo MC. O desafio do conhecimento: pesquisa qualitativa em saúde. $7^{a}$ ed. São Paulo: Hucitec; 1996. 
, et all. Métodos, técnicas e relações em triangulação. In Minayo MCS, Assis, SGS, Edinilsa R (org). Avaliação por triangulação de métodos: abordagem de programas sociais. Rio de Janeiro, Editora Fiocruz, 2005.

Moreira A. A profissionalização da enfermagem. In: Oguisso T. (org) Trajetória histórica e legal da enfermagem. São Paulo: Manole; 2005.

Morin E. Os Sete Saberes necessários à Educação do Futuro. São Paulo: Cortez; Brasília: UNESCO; 2000.

Kern AB. Terra-Pátria. Instituto Piaget: Lisboa, 1993.

Mucchielli R. L'analyse de contenu dês documents et dês communications. Paris: Les Librairies Techniques; 1977.

Nietsche EA. As teorias da educação e o ensino da enfermagem no Brasil In: Saupe R. (org). Educação em enfermagem. Florianópolis: Editora UFSC; 1998.

Nimtz M.A. O significado de competência para o decente de administração em enfermagem.[tese de doutorado] São Paulo: Escola de Enfermagem da Universidade de São Paulo; 2003.

Nóvoa A. Professor se forma na escola. Fala, Mestre! [periódico on line] São Paulo; disponível em <http://novaescola.abril.com.br/ed/142_mai01/html/fala_mestre.htm> mai 2001. (acessado em 19-06-2006)

. La profession enseignante em Europe: Analyse historique et sociologique. Projeto PCSH/C/CED/908/95, 1.995 (Mimeo) apud Lüdke M, Moreira AFB, Cunha MI. Repercussões de tendências internacionais sobre a formação de nossos professores. In Educação \& Sociedade: Campinas; ano XX, n.ำ68; 1999. (278-298).

. Relação escola-sociedade: "novas respostas para um velho problema". In: Serbino RV, Ribeiro R, Barbosa RLL, Gebran RA (org.) Formação de Professores. São Paulo: Fundação Editora da UNESP, 1998.

.O passado e o presente dos professores. In: Nóvoa A. (org.) Profissão professor. Porto: Porto Editora, 1995.

Oguisso T. (org) Trajetória histórica e legal da enfermagem. São Paulo: Manole, 2005.

Paiva JM. Educação jesuítica no Brasil colonial. In: Lopes EMT, Faria Filho LM, Veiga, CG. 500 anos de educação no Brasil. 3aㅡ ed. Belo Horizonte: Autêntica Editora. 2003.

Paixão W. Páginas da história da enfermagem. Rio de Janeiro: Universidade do Brasil; 1951.

Pereira EMA. Professor como pesquisador: o enfoque da pesquisa-ação na prática docente. In: Geraldi CMG, Fiorentini D, Pereira EMA. (orgs) Cartografia do trabalho docente: professor(a)-pesquisador(a). 2 $2^{\mathrm{a}}$ ed. Campinas: Mercado das Letras. 2000.

Perrenoud P. A formação dos professores no século XXI. In: Perrenoud P et all. As competências para ensinar no século XXI: a formação dos professores e o desafio da avaliação. Porto Alegre: ArtMed Editora, 2002.

Construir as competências desde a escola. Porto Alegre: Artes Médicas Sul, 1999.

2000.

Dez novas competências para Ensinar. Porto Alegre: Artes Médicas Sul, 
Pires MFC. O materialismo histórico-dialético e a Educação. In: Revista Interface. Botucatu: Fundação UNI e UNESP. v.1, no1 [83-94]. 1997; disponível em <http://www.interface. org.br/revista1/ensaio5.pdf> acesso em 29.05.2006.

Poentes R.V. Os estudos das teorias educativas na América Latina. S.João da Boa Vista: Ed. UNIFEOB; 2004.

Ramos MN. A pedagogia das competências: autonomia ou adaptação? $2^{\underline{a}}$ ed. São Paulo: Cortez, 2002.

Ressel LB, Gualda DMR, Gonzáles RMB. Grupo focal como estratégia para coletar dados de pesquisa em enfermagem. International Journal of Qualitative Methods 1 (2), Article 5. (2002). Disponível em: <http://www.ualberta.ca/ iiqm/backissues/1_2Final/html/ressel. html>. (acesso em 20 Set 2005)

Romanelli OO. História da Educação no Brasil. 27ª̣ ed.Petrópolis: Editora Vozes; 2002.

Sacristan JG, Gómez AP. Compreender e transformar o ensino. Porto Alegre: Artmed; 1998.

Saupe R. (org). Educação em enfermagem. Florianópolis: Editora da UFSC; 1998.

Saviani D. O legado educacional do "Longo Século XX" no Brasil. In: Saviani D, Almeida, JS, Souza RF, Valdemarin VT. (org) O legado educacional do Século XX no Brasil. Campinas: Editora Autores Associados; 2004.

Silva GB. Enfermagem profissional: análise crítica. São Paulo: Cortez, 1986.

Silveira TF. Significados e conflitos da docência no ensino superior de enfermagem. [dissertação de mestrado] Campinas: PUC Campinas, 2004.

Schön D. The reflective practioner. New York: Basic Books, 1983.

Shinyashiki R. Prefácio. In: D’Elia MES. Profissionalismo: não dá para não ter. São Paulo: Gente, 1997.

Sordi MRL, Sampaio SF, Alves FP, Adão G. A mudança da prática docente como determinante de um novo conceito de qualidade de ensino em Enfermagem. In: Texto \& Contexto-Enfermagem; Florianópolis: UFSC. vol. 8; ㄲo1 (243-255) jan-abr 1999.

Stroobants M. A visibilidade das competências. In: Tanguy L, Ropé F. Saberes e competências: o uso de tais noções na escola e na empresa. $3^{\underline{a}}$ ed. Campinas: Papirus; 2002.

Tardif M. Saberes docentes e Formação Profissional. 3를 ed. Petrópolis: Vozes; 2002

Thiollent, M. Metodologia da pesquisa-ação. 6ª ed. São Paulo, Cortez; 1994.

Tobias JA. História da Educação Brasileira. 3ae ed. São Paulo: IBRASA; 1986.

Vasconcellos CS. Para onde vai o Professor? Resgate do professor como sujeito de transformação. 8ª ed. São Paulo: Libertad, 2001.

Valdemarin VT. Os sentidos e a experiência: professores, alunos e métodos de ensino. In: Saviani D, Almeida JS, Souza RF, Valdemarin VT. (org) O legado educacional do Século XX no Brasil. Campinas: Editora Autores Associados; 2004.

Whestphal MF, Bogus CM, Faria MM. Grupos focais: experiências precursoras em programas educativos em saúde no Brasil. Boletim Oficial Sanit Panam 1996, [p.473-4]

Xavier MESP. Poder político e educação de elite. São Paulo: Cortez Editora, Autores Associados. 1992. 
ANEXOS 


\section{ANEXO 1 \\ Ofício para a solicitação de autorização para coleta de dados.}

Campinas, 31de maio de 2005.

II.mo Sr (a) $\operatorname{Prof}^{a}{ }^{-} r^{-a}$ Maria Teresa Cristina L.T. Martins

MD. Diretora da Faculdade de Enfermagem da PUC Campinas

Prezado Sr (a)

Venho por meio desta, solicitar autorização para realizar a coleta de dados para o trabalho de pesquisa, intitulado: "O desenvolvimento de competências para a docência: a experiência de docentes de um curso de graduação em enfermagem", nesta instituição, de acordo com o projeto em anexo que tem como objetivo: conhecer quando e como os docentes do ensino superior de Enfermagem desenvolvem competências na esfera da docência.

Aproveito o ensejo para esclarecer, tratar-se de um trabalho de pesquisa para obtenção do Título de Doutor do Programa de Pós Graduação da Escola de Enfermagem da Universidade de São Paulo sob orientação da Profa ${ }^{-a} r^{\text {a }}$ Paulina Kurcgant.

Outrossim, esclarecemos que não colocaremos em evidência a identificação de qualquer profissional e ou instituição participante.

Certo de podermos contar com a sua colaboração, coloco-me à disposição para maiores esclarecimentos pelos telefones: 32551539 ou 97657720, no endereço: Av. Princesa D'oeste, 440 apto 112 Campinas- SP. CEP:13095-010.

No aguardo de sua resposta, aproveitamos a oportunidade para renovar nossos protestos de estima e consideração.

Atenciosamente,

Prof ${ }^{a}$ Dra Paulina Kurcgant

Orientadora do projeto
Enf ${ }^{a}$ Inahiá Pinhel

Pesquisadora responsável 


\section{ANEXO 2}

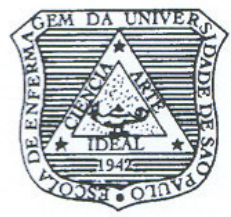

\section{UNIVERSIDADE DE SÃO PAULO ESCOLA DE ENFERMAGEM}

Av. Dr. Enéas de Carvalho Aguiar, 419 - CEP 05403-000

? Fone.: 3066-7548 - Fax.: 280-8213

C.P. 41633 - CEP 05422-970 - e-mail.: edipesq@usp.br

São Paulo, 13 de junho de 2005.

$\mathrm{Ilm}^{\mathrm{a}} \mathrm{Sr}^{\mathrm{a}}$

Inahiá Pinhel

Ref.: Processo n ${ }^{\circ}$ 444/2005/CEP-EEUSP

Prezada Senhora,

Em atenção à solicitação referente à análise do projeto "O DESENVOLVIMENTO DE COMPETÊNCIAS PARA A DOCÊNCIA: A EXPERIÊNCIA DE DOCENTES DE UM CURSO DE GRADUAÇÃO EM ENFERMAGEM", informamos que o mesmo foi considerado aprovado pelo Comitê de Ética em Pesquisa da Escola de Enfermagem da Universidade de São Paulo (CEP/EEUSP).

Analisado sob o aspecto ético-legal, atende às exigências da Resolução no 196/96 do Conselho Nacional de Saúde.

Esclarecemos que após o término da pesquisa, os resultados obtidos deverão ser encaminhados ao CEP/EEUSP, para serem anexados ao processo.

Atenciosamente,

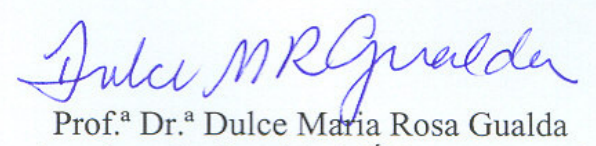

Coordenadora do Comitê de Ética em Pesquisa da Escola de Enfermagem da Universidade de São Paulo 


\begin{abstract}
ANEXO 3
TERMO DE CONSENTIMENTO LIVRE E ESCLARECIDO - ENTREVISTAS

Eu, Inahiá Pinhel, doutoranda do programa Interunidades da Escola de Enfermagem da Universidade de São Paulo, gostaria de convidá-la para participar da pesquisa $O$ desenvolvimento de competências para a docência: a experiência de docentes de um curso de graduação em enfermagem, que tem como objetivo conhecer quando e como os docentes do ensino superior de enfermagem desenvolvem competências na esfera da docência.
\end{abstract}

A coleta de dados será realizada através de entrevista individual, que será gravada para manter a fidedignidade do conteúdo.

Se você concordar em participar, voluntariamente, do estudo, sua contribuição será de grande importância e será assegurado o respeito aos seus direitos abaixo relacionados:

- liberdade de retirar seu consentimento a qualquer momento e/ou deixar de participar do estudo sem que isso traga qualquer prejuízo ou penalização;

- garantia do anonimato, do sigilo e do caráter confidencial das informações;

- garantia da não existência de danos e riscos à sua pessoa.

O relatório obtido após análise dos dados do conjunto das entrevistas, será utilizado para a discussão em grupos focais.

Esse termo de consentimento livre e esclarecido será feito em duas vias sendo que uma ficará com você e a outra, arquivada comigo.

Após a conclusão do trabalho, ele será divulgado através de publicações e apresentações em eventos.

Caso você tenha alguma dúvida, o telefone do Comitê de Ética em Pesquisa da EE-USP é (011) 3066-7548. Eu também estarei à disposição para esclarecimentos pelo telefone (019) 32551539 ou (019) 97657720 e pelo e-mail: inahiap@uol.com.br 


\section{ANEXO 4}

\section{CARACTERIZAÇÃO DOS SUJEITOS}

Nome:

Idade:

Sexo:

Ano de formatura de graduação:

Outros cursos realizados:

- Aprimoramento Ano de conclusão

- Especialização: Ano de conclusão

- Mestrado: Ano de conclusão

- Doutorado: Ano de conclusão

- Outros: Ano de conclusão Ano de conclusão

Há quanto tempo trabalha como docente?

Há quanto tempo trabalha nesta Instituição de Ensino?

\section{Questões Norteadoras do Estudo}

- Como ocorreu a sua capacitação para ser docente de Enfermagem?

- Como você percebe que ocorre a sua capacitação hoje?

- Como você pensa que deva ser a continuidade desta capacitação? 


\begin{abstract}
ANEXO 5
TERMO DE CONSENTIMENTO LIVRE E ESCLARECIDO - GRUPO FOCAL

Eu, Inahiá Pinhel, doutoranda do programa Interunidades da Escola de Enfermagem da Universidade de São Paulo, gostaria de convidá-la para participar da pesquisa $O$ desenvolvimento de competências para a docência: a experiência de docentes de um curso de graduação em enfermagem, que tem como objetivo conhecer quando e como os docentes do ensino superior de enfermagem desenvolvem competências na esfera da docência.
\end{abstract}

A coleta de dados será realizada através de grupo focal, que será gravado para manter a fidedignidade do conteúdo.

Se você concordar em participar, voluntariamente, do estudo, sua contribuição será de grande importância e será assegurado o respeito aos seus direitos abaixo relacionados:

- liberdade de retirar seu consentimento a qualquer momento e/ou deixar de participar do estudo sem que isso traga qualquer prejuízo ou penalização;

- garantia do anonimato, do sigilo e do caráter confidencial das informações;

- garantia da não existência de danos e riscos à sua pessoa.

Esse termo de consentimento livre e esclarecido será feito em duas vias sendo que uma ficará com você e a outra arquivada comigo.

Após a conclusão do trabalho, ele será divulgado através de publicações e apresentações em eventos.

Caso você tenha alguma dúvida, o telefone do Comitê de Ética em Pesquisa da EE-USP é (011) 3066-7548. Eu também estarei à disposição para esclarecimentos pelo telefone (019) 32551539 ou (019) 97657720 e pelo e-mail: inahiap@uol.com.br

Assinatura do participante

Inahiá Pinhel - Pesquisadora 


\title{
ANEXO 6
}

\section{CONSELHO NACIONAL DE EDUCAÇÃO ${ }^{66}$ CÂMARA DE EDUCAÇÃO SUPERIOR}

\author{
RESOLUÇÃO CNE/CES N 3, DE 7 DE NOVEMBRO DE 2001.
}

Institui as Diretrizes Curriculares Nacionais do Curso de Graduação em Enfermagem.

O Presidente da Câmara de Educação Superior do Conselho Nacional de Educação, tendo em vista o disposto no Art. $9^{\circ}$, do $\S 2^{\circ}$, alínea "c", da Lei n ${ }^{\circ} 9.131$, de 25 de novembro de 1995 , e com fundamento no Parecer CNE/CES 1.133, de 7 de agosto de 2001, peça indispensável do conjunto das presentes Diretrizes Curriculares Nacionais, homologado pelo Senhor Ministro da Educação, em $1^{\circ}$ de outubro de 2001,

\section{RESOLVE:}

Art. $1^{\circ}$ A presente Resolução institui as Diretrizes Curriculares Nacionais do Curso de Graduação em Enfermagem, a serem observadas na organização curricular das Instituições do Sistema de Educação Superior do País.

Art. $2^{\circ}$ As Diretrizes Curriculares Nacionais para o Ensino de Graduação em Enfermagem definem os princípios, fundamentos, condições e procedimentos da formação de enfermeiros, estabelecidas pela Câmara de Educação Superior do Conselho Nacional de Educação, para aplicação em âmbito nacional na organização, desenvolvimento e avaliação dos projetos pedagógicos dos Cursos de Graduação em Enfermagem das Instituições do Sistema de Ensino Superior.

Art. $3^{\circ} \mathrm{O}$ Curso de Graduação em Enfermagem tem como perfil do formando egresso/profissional:

I - Enfermeiro, com formação generalista, humanista, critica e reflexiva. Profissional qualificado para o exercício de Enfermagem, com base no rigor científico e intelectual e pautado em princípios éticos. Capaz de conhecer e intervir sobre os problemas/situações de saúde-doença mais prevalentes no perfil epidemiológico nacional, com ênfase na sua região de atenção, identificando as dimensões bio-psicosociais dos seus determinantes. Capacitado a atuar, com senso de responsabilidade social e compromisso com a cidadania, como promotor da saúde integral do ser humano; e

II - Enfermeiro com Licenciatura em Enfermagem capacitado para atuar na Educação Básica e na Educação Profissional em Enfermagem.

Art. $4^{\circ}$ A formação do enfermeiro tem por objetivo dotar o profissional dos conhecimentos requeridos para o exercício das seguintes competências e habilidades gerais:

I - Atenção à saúde: os profissionais de saúde, dentro de seu âmbito profissional, devem estar aptos a desenvolver ações de prevenção, promoção, proteção e reabilitação da saúde, tanto em nível individual quanto coletivo. Cada profissional deve assegurar que sua prática seja realizada de forma integrada e contínua com as demais instâncias do sistema de saúde, sendo capaz de pensar criticamente, de analisar os problemas da sociedade e de procurar soluções para os mesmos. Os profissionais devem realizar seus serviços dentro dos mais altos padrões de qualidade e dos princípios da ética/bioética, tendo em conta que a responsabilidade da atenção à saúde não se encerra com o ato técnico, mas sim, com a resolução do problema de saúde, tanto em nível individual como coletivo;

${ }^{66}$ CONSELHO NACIONAL DE EDUCAÇÃO. Câmara de Educação Superior. Resolução CNE/CES 3/2001. Diário Oficial da União, Brasília, 9 de Novembro de 2001. Seção 1, p. 37. 
II - Tomada de decisões: o trabalho dos profissionais de saúde deve estar fundamentado na capacidade de tomar decisões visando o uso apropriado, eficácia e custoefetividade, da força de trabalho, de medicamentos, de equipamentos, de procedimentos e de práticas. Para este fim, os mesmos devem possuir competências e habilidades para avaliar, sistematizar e decidir as condutas mais adequadas, baseadas em evidências científicas;

III - Comunicação: os profissionais de saúde devem ser acessíveis e devem manter a confidencialidade das informações a eles confiadas, na interação com outros profissionais de Saúde e o público em geral A comunicação envolve comunicação verbal, não-verbal e habilidades de escrita e leitura; o domínio de, pelo menos, uma língua estrangeira e de tecnologias de comunicação e informação;

IV - Liderança: no trabalho em equipe multiprofissional, os profissionais de saúde deverão estar aptos a assumir posições de liderança, sempre tendo em vista o bem-estar da comunidade. A liderança envolve compromisso, responsabilidade, empatia, habilidade para tomada de decisões, comunicação e gerenciamento de forma efetiva e eficaz;

V - Administração e gerenciamento: os profissionais devem estar aptos a tomar iniciativas, fazer o gerenciamento e administração tanto da força de trabalho quanto dos recursos fisicos e materiais e de informação, da mesma forma que devem estar aptos a serem empreendedores, gestores, empregadores ou lideranças na equipe de saúde; e

VI - Educação permanente: os profissionais devem ser capazes de aprender continuamente, tanto na sua formação, quanto na sua prática. Desta forma, os profissionais de saúde devem aprender a aprender e ter responsabilidade e compromisso com a sua educação e o treinamento/estágios das futuras gerações de profissionais, mas proporcionando condições para que haja beneficio mútuo entre os futuros profissionais e os profissionais dos serviços, inclusive, estimulando e desenvolvendo a mobilidade acadêmico/profissional, a formação e a cooperação por meio de redes nacionais e internacionais.

Art. $5^{\circ}$ A formação do enfermeiro tem por objetivo dotar o profissional dos conhecimentos requeridos para o exercício das seguintes competências e habilidades específicas:

I - atuar profissionalmente, compreendendo a natureza humana em suas dimensões, em suas expressões e fases evolutivas;

II - incorporar a ciência/arte do cuidar como instrumento de interpretação profissional;

III - estabelecer novas relações com o contexto social, reconhecendo a estrutura e as formas de organização social, suas transformações e expressões;

IV - desenvolver formação técnico-científica que confira qualidade ao exercício profissional;

V - compreender a política de saúde no contexto das políticas sociais, reconhecendo os perfis epidemiológicos das populações;

VI - reconhecer a saúde como direito e condições dignas de vida e atuar de forma a garantir a integralidade da assistência, entendida como conjunto articulado e contínuo das ações e serviços preventivos e curativos, individuais e coletivos, exigidos para cada caso em todos os níveis de complexidade do sistema;

VII - atuar nos programas de assistência integral à saúde da criança, do adolescente, da mulher, do adulto e do idoso;

VIII - ser capaz de diagnosticar e solucionar problemas de saúde, de comunicar-se, de tomar decisões, de intervir no processo de trabalho, de trabalhar em equipe e de enfrentar situações em constante mudança;

IX - reconhecer as relações de trabalho e sua influência na saúde;

$\mathrm{X}$ - atuar como sujeito no processo de formação de recursos humanos;

XI - responder às especificidades regionais de saúde através de intervenções planejadas estrategicamente, em níveis de promoção, prevenção e reabilitação à saúde, dando atenção integral à saúde dos indivíduos, das famílias e das comunidades;

XII - reconhecer-se como coordenador do trabalho da equipe de enfermagem; 
XIII - assumir o compromisso ético, humanístico e social com o trabalho multiprofissional em saúde.

XIV - promover estilos de vida saudáveis, conciliando as necessidades tanto dos seus clientes/pacientes quanto às de sua comunidade, atuando como agente de transformação social;

XV - usar adequadamente novas tecnologias, tanto de informação e comunicação, quanto de ponta para o cuidar de enfermagem;

XVI - atuar nos diferentes cenários da prática profissional, considerando os pressupostos dos modelos clínico e epidemiológico;

XVII - identificar as necessidades individuais e coletivas de saúde da população, seus condicionantes e determinantes;

XIII - intervir no processo de saúde-doença, responsabilizando-se pela qualidade da assistência/cuidado de enfermagem em seus diferentes níveis de atenção à saúde, com ações de promoção, prevenção, proteção e reabilitação à saúde, na perspectiva da integralidade da assistência;

XIX - coordenar o processo de cuidar em enfermagem, considerando contextos e demandas de saúde;

$\mathrm{XX}$ - prestar cuidados de enfermagem compatíveis com as diferentes necessidades apresentadas pelo indivíduo, pela família e pelos diferentes grupos da comunidade;

XXI - compatibilizar as características profissionais dos agentes da equip e de enfermagem às diferentes demandas dos usuários;

XXII - integrar as ações de enfermagem às ações multiprofissionais;

XXIII - gerenciar o processo de trabalho em enfermagem com princípios de Ética e de Bioética, com resolutividade tanto em nível individual como coletivo em todos os âmbitos de atuação profissional;

XXIV - planejar, implementar e participar dos programas de formação e qualificação contínua dos trabalhadores de enfermagem e de saúde;

XXV - planejar e implementar programas de educação e promoção à saúde, considerando a especificidade dos diferentes grupos sociais e dos distintos processos de vida, saúde, trabalho e adoecimento;

XXVI - desenvolver, participar e aplicar pesquisas e/ou outras formas de produção de conhecimento que objetivem a qualificação da prática profissional;

XXVII - respeitar os princípios éticos, legais e humanísticos da profissão;

XXIII - interferir na dinâmica de trabalho institucional, reconhecendo-se como agente desse processo;

XXIX - utilizar os instrumentos que garantam a qualidade do cuidado de enfermagem e da assistência à saúde;

XXX - participar da composição das estruturas consultivas e deliberativas do sistema de saúde;

XXXI - assessorar órgãos, empresas e instituições em projetos de saúde;

XXXII - cuidar da própria saúde física e mental e buscar seu bem-estar como cidadão e como enfermeiro; $\mathrm{e}$

XXXIII - reconhecer o papel social do enfermeiro para atuar em atividades de política e planejamento em saúde.

Parágrafo Único. A formação do Enfermeiro deve atender as necessidades sociais da saúde, com ênfase no Sistema Único de Saúde (SDS) e assegurar a integralidade da atenção e a qualidade e humanização do atendimento.

Art. $6^{\circ}$ Os conteúdos essenciais para o Curso de Graduação em Enfermagem devem estar relacionados com todo o processo saúde-doença do cidadão, da família e da comunidade, integrado à realidade epidemiológica e profissional, proporcionando a integralidade das ações do cuidar em enfermagem Os conteúdos devem contemplar:

I - Ciências Biológicas e da Saúde- incluem-se os conteúdos (teóricos e práticos) de base moleculares e celulares dos processos normais e alterados, da estrutura e função dos tecidos, órgãos, sistemas e aparelhos, aplicados às situações decorrentes do processo 
saúde-doença no desenvolvimento da prática assistencial de Enfermagem;

II - Ciências Humanas e Sociais - incluem-se os conteúdos referentes às diversas dimensões da relação indivíduo/sociedade, contribuindo para a compreensão dos determinantes sociais, culturais, comportamentais, psicológicos, ecológicos, éticos e legais, nos níveis individual e coletivo, do processo saúde-doença;

III - Ciências da Enfermagem - neste tópico de estudo, incluem-se:

a) Fundamentos de Enfermagem: os conteúdos técnicos, metodológicos e os meios e instrumentos inerentes ao trabalho do Enfermeiro e da Enfermagem em nível individual e coletivo;

b) Assistência de Enfermagem: os conteúdos (teóricos e práticos) que compõem a assistência de Enfermagem em nível individual e coletivo prestada à criança, ao adolescente, ao adulto, à mulher e ao idoso, considerando os determinantes sócioculturais, econômicos e ecológicos do processo saúde-doença, bem como os princípios éticos, legais e humanísticos inerentes ao cuidado de Enfermagem;

c) Administração de Enfermagem: os conteúdos (teóricos e práticos) da administração do processo de trabalho de enfermagem e da assistência de enfermagem; e

d) Ensino de Enfermagem: os conteúdos pertinentes à capacitação pedagógica do enfermeiro, independente da Licenciatura em Enfermagem.

$\S 1^{\circ}$ - Os conteúdos curriculares, as competências e as habilidades a serem assimilados e adquiridos no nível de graduação do enfermeiro devem conferir-lhe terminalidade e capacidade acadêmica e/ou profissional, considerando as demandas e necessidades prevalentes e prioritárias da população conforme o quadro epidemiológico do país/região.

$\S 2^{\circ}$ - Este conjunto de competências, conteúdos e habilidades deve promover no aluno e no enfermeiro a capacidade de desenvolvimento intelectual e profissional autônomo e permanente.

Art. $7^{\circ} \mathrm{Na}$ formação do Enfermeiro, além dos conteúdos teóricos e práticos desenvolvidos ao longo de sua formação, ficam os cursos obrigados a incluir no currículo o estágio supervisionado em hospitais gerais e especializados, ambulatórios, rede básica de serviços de saúde e comunidades nos dois últimos semestres do Curso de Graduação em Enfermagem.

Parágrafo Único. Na elaboração da programação e no processo de supervisão do aluno, em estágio curricular supervisionado, pelo professor, será assegurada efetiva participação dos enfermeiros do serviço de saúde onde se desenvolve o referido estágio. A carga horária mínima do estágio curricular supervisionado deverá totalizar 20\% (vinte por cento) da carga horária total do Curso de Graduação em Enfermagem proposto, com base no Parecer/Resolução específico da Câmara de Educação Superior do Conselho Nacional de Educação.

Art. $8^{\circ}$ O projeto pedagógico do Curso de Graduação em Enfermagem deverá contemplar atividades complementares e as Instituições de Ensino Superior deverão criar mecanismos de aproveitamento de conhecimentos, adquiridos pelo estudante, através de estudos e práticas independentes, presenciais e/ou a distância, a saber: monitorias e estágios; programas de iniciação científica; programas de extensão; estudos complementares e cursos realizados em outras áreas afins.

Art. $9^{\circ} \mathrm{O}$ Curso de Graduação em Enfermagem deve ter um projeto pedagógico, construído coletivamente, centrado no aluno como sujeito da aprendizagem e apoiado no professor como facilitador e mediador do processo ensino-aprendizagem. Este projeto pedagógico deverá buscar a formação integral e adequada do estudante através de uma articulação entre o ensino, a pesquisa e a extensão/assistência.

Art. 10. As Diretrizes Curriculares e o Projeto Pedagógico devem orientar o Currículo do Curso de Graduação em Enfermagem para um perfil acadêmico e profissional do egresso. Este currículo deverá contribuir, também, para a compreensão, interpretação, preservação, reforço, fomento e difusão das culturas nacionais e regionais, internacionais e históricas, em um contexto de pluralismo e diversidade cultural.

$\S \mathbf{1}^{\circ}$ As diretrizes curriculares do Curso de Graduação em Enfermagem deverão contribu- 
ir para a inovação e a qualidade do projeto pedagógico do curso.

$\S 2^{\circ}$ O Currículo do Curso de Graduação em Enfermagem deve incluir aspectos complementares de perfil, habilidades, competências e conteúdos, de forma a considerar a inserção institucional do curso, a flexibilidade individual de estudos e os requerimentos, demandas e expectativas de desenvolvimento do setor saúde na região.

Art. 11 ${ }^{\circ}$. A organização do Curso de Graduação em Enfermagem deverá ser definida pelo respectivo colegiado do curso, que indicará a modalidade: seriada anual, seriada semestral, sistema de créditos ou modular.

Art. 12 . Para conclusão do Curso de Graduação em Enfermagem, o aluno deverá elaborar um trabalho sob orientação docente.

Art. 13 . A Formação de Professores por meio de Licenciatura Plena segue Pareceres e Resoluções específicos da Câmara de Educação Superior e do Pleno do Conselho Nacional de Educação.

Art. 14 ${ }^{\circ}$. A estrutura do Curso de Graduação em Enfermagem deverá assegurar:

I - a articulação entre o ensino, pesquisa e extensão/assistência, garantindo um ensino crítico, reflexivo e criativo, que leve a construção do perfil almejado, estimulando a realização de experimentos e/ou de projetos de pesquisa; socializando o conhecimento produzido, levando em conta a evolução epistemológica dos modelos explicativos do processo saúde-doença;

II - as atividades teóricas e práticas presentes desde o início do curso, permeando toda a formação do Enfermeiro, de forma integrada e interdisciplinar;

III - a visão de educar para a cidadania e a participação plena na sociedade;

IV - os princípios de autonomia institucional, de flexibilidade, integração estudo/trabalho e pluralidade no currículo;

$\mathrm{V}$ - a implementação de metodologia no processo ensinar-aprender que estimule o aluno a refletir sobre a realidade social e aprenda a aprender;

VI - a definição de estratégias pedagógicas que articulem o saber; o saber fazer e o saber conviver, visando desenvolver o aprender a aprender, o aprender a ser, o aprender a fazer, o aprender a viver juntos e o aprender a conhecer que constitui atributos indispensáveis à formação do Enfermeiro;

VII - o estímulo às dinâmicas de trabalho em grupos, por favorecerem a discussão coletiva e as relações interpessoais;

VIII - a valorização das dimensões éticas e humanísticas, desenvolvendo no aluno e no enfermeiro atitudes e valores orientados para a cidadania e para a solidariedade; e

IX - a articulação da Graduação em Enfermagem com a Licenciatura em Enfermagem.

Art. 15 $^{\circ}$. A implantação e desenvolvimento das diretrizes curriculares devem orientar e propiciar concepções curriculares ao Curso de Graduação em Enfermagem que deverão ser acompanhadas e permanentemente avaliadas, a fim de permitir os ajustes que se fizerem necessários ao seu aperfeiçoamento.

$\S 1^{\circ}$ As avaliações dos alunos deverão basear-se nas competências, habilidades e contemos curriculares desenvolvidos, tendo como referência as Diretrizes Curriculares.

$\S 2^{\circ} \mathrm{O}$ Curso de Graduação em Enfermagem deverá utilizar metodologias e critérios para acompanhamento e avaliação do processo ensino-aprendizagem e do próprio curso, em consonância com o sistema de avaliação e a dinâmica curricular definidos pela IES à qual pertence.

Art. $1^{\circ}$. Esta Resolução entra em vigor na data de sua publicação, revogadas as disposições em contrário.

Arthur Roquete de Macedo Presidente da Câmara de Educação Superior 
ANEXO 7

TRANSCRIÇÃO DAS ENTREVISTAS - 1르 FASE 


\section{Entrevista E-01 \\ 1 - Como ocorreu a sua capacitação e quais competências julga que desenvolveu?}

Não houve uma capacitação formal, eu acho que vamos experimentando durante a nossa formação algumas aproximações com o ensinar e aprender com transmissão de conhecimento por mais conservadora que ela seja, a formação da Enfermagem ela propicia isso, essa capacitação. Eu nunca fui uma aluna que foi monitora e nunca tive iniciação científica, então eu nem posso te dizer que tive algo mais sofisticado na minha formação que me possibilitasse essa aproximação como aluna, o que eu tive foi, em alguns estágios a possibilidade de trabalhar com temas de educação e saúde, principalmente na área da saúde coletiva que sempre foi o meu eixo maior, o meu interesse maior durante a formação, então trabaIho voluntário em comunidade, em escola porque eu gostava de estar junto da população carente e mais os estágios que também ajudavam, então não houve uma capacitação formal houve essa aproximação dessa forma, muito incipiente mas muito significativa, agora que você está me perguntando ela foi muito significativa, essa forma de trabalhar com o conhecimento a partir, ou, por meio dessas experiências com educação e saúde; então sempre tinha o tema da educação e saúde, mas tem uma coisa que eu vou me permitir que estou me lembrando agora, eu e minha irmã gêmea quando estudávamos em escola do ensino fundamental, nós tínhamos algumas colegas que tinham dificuldade em algumas disciplinas, então nós compramos lousa e giz e levávamos as amigas para casa e éramos as professoras delas, usando quadro, giz, fazendo prova, estudo dirigido. E quando eu estava na faculdade, as minhas colegas gostavam de estudar comigo, porque eu tinha uma facilidade de reprisar ou revisar a matéria com elas e geralmente elas tiravam notas muito boas e eu tirava nota menor, me lembrei disso agora, se você quiser usar você usa.Então eu tenho uma certa facilidade, eu acho, não dá para ignorar, uma certa facilidade de comunicação, de falar. Eu considero que as competências desenvolvidas foram: a comunicação, a percepção de algumas variáveis que fazem parte do processo de ensinar e aprender tais como histórias de vida, exemplos vividos profissionalmente, situações vivenciadas em estágios com alunos e levadas para a sala de aula para outros alunos, compartilhamento de emoções, lições de vida, alteração dos julgamentos pré-estabelecidos e que diante de uma situação que você jurava que agiria de tal forma, você se depara agindo de outra e isso é bom, pode se rever, alterar coisas e modos de pensar.

\section{2- Como você percebe que ocorre a sua capacitação hoje? E quais as competências que julga es- tar desenvolvendo hoje?}

Sem dúvida nenhuma o conhecimento, o estudo, o meu aprimoramento pessoal e profissional de certa forma foi dirigindo para um determinado tema, me aprofundando numa determinada área de conhecimento. É um elemento facilitador, porque eu posso transitar nessa área com muito mais facilidade sem dúvida alguma. Mas tem uma coisa na docência que ela é além do que o conhecimento pode trazer, ela passa por outra dimensão que também não sei dizer qual é... dessa interação, desse posicionamento em sala, dessa relação com o conhecimento, com momentos de tolerância com momentos de exigências eu acho que é uma coisa para ser vivida mesmo, não sei se existe um modelo, não sei se existe uma prédeterminação, porque a gente acaba também vivendo a docência com muita ressonância daquilo que a gente está naquele dia, porque nós somos gente como qualquer outro que tem dificuldades, alegrias, amores e dissabores como qualquer outro e que em algum momento interfere numa aula melhor, ou....Agora existe algo na nossa profissão que ajuda muito essa coisa da docência, nós temos uma vivência prática e esta vivência possibilita transitar entre a teoria e a prática e fazer estas ligações, e a prática alimentar teoria e alimentar aqueles exemplos e aquelas vivências e eu acho isso muito bom e ao contar essa vivência para os alunos, trazê-las com as emoções vividas e não apenas como mais um episódio que aconteceu na vida da gente como enfermeiro, mas, quais foram os sentimentos, as sensações, as dificuldades vividas naquele momento, e acho que isso faz com haja uma aproximação nesse momento do aluno quando ele pode olhar para a gente e falar assim: ela já cresceu e também tem dificuldade, ela já andou alguns quilômetros rodados e ela também tem medos, ela já se aprimorou formalmente com títulos e etc e também se vê em situações difíceis. Então a nossa profissão é uma profissão difícil, complexa, bela e eu acho que essa dimensão, essa coisa ampla faz com que nossos alunos consigam fazer uma parceria com a gente, e eu tenho percebido isso e tem sido muito melhor.

Eu verdadeiramente quero acreditar que o meu agir como professora, carregado de intencionalidade de transformação, possa estar propiciando o desenvolvimento do compromisso com a transformação social, que possa estar convencendo os alunos que devemos colocar nosso trabalho a serviço do outro e que esse trabalho é uma prática social, da qual, os primeiros beneficiários devam ser aqueles excluídos da 
sociedade, estão mergulhados em sofrimento, seja este de que ordem for, mas que expressa o sofrimento de uma sociedade que clama por profundas transformações. Pensar assim, sempre vale a pena e mesmo que eu não consiga efetivamente este intento, colocar a docência nessa perspectiva terá sempre valido a pena. Acho que a competência que estou desenvolvendo seja a de acreditar que outro mundo é possível .

\section{3- Como você pensa que deva ser a continuidade dessa capacitação? E quais competências julga que ainda deva desenvolver?}

Eu não sei, acho que estou vivendo um momento ímpar da docência e não sei como ela deva ser, estou gostando como ela está sendo agora, sem muita preocupação com a minha performance, sem muita preocupação de que forma 0 aluno vai entender a minha figura ali, sem muita preocupação também se eu sou uma autoridade ou não, mas eu estou querendo estabelecer pela docência uma relação com conhecimento que necessariamente traga algo que eu acho essencial que é a ética no cuidado, isso para mim é o fundamental. Então se eu puder fazer uso da docência, a docência para mim é.....ela é uma ferramenta, quantas vezes eu precisar mudá-la eu vou mudar para fazer com que esse principio da ética do cuidado caiba nela. Então por hora está me satisfazendo o modo como eu estou fazendo essa docência, lá na frente eu não sei como será, o que não posso é perder o eixo fundamental que é a ética do cuidado, eu não sei como ela vai acontecer, pois ela simplesmente está acontecendo. Tem uma coisa que me ocorreu agora que eu queria que ficasse registrado e que eu acho importante, até porque será utilizado no trabaIho de alguma forma, o espaço a docência ela trás uma autonomia por mais que a instituição possa fazer amarras, quando você fecha a porta da sala de aula é mais ou menos como um casal que fecha a porta do quarto e ali dentro vale tudo, quando é com amor, quando os dois querem, tudo é bom, tudo é bom. Então quando você fecha a porta de uma sala de aula ali não tem ninguém que roube as suas idéias, não tem ninguém que roube os seus princípios ninguém é capaz de fazer isso ninguém é capaz de controlar, esse é o maior prazer que tenho de saber que não fui totalmente capturada, essa essência ninguém captura só se eu quiser de livre e espontânea vontade mas ninguém captura. Então podem até fazer expectativa, a instituição pode até ter expectativa de qual é o "modelito" da docência, mas se você não quiser abrir mão, você não abre mão. Então eu acho a profissão professor ela permite que você faça isso, e eu acho isso muito bom e isso dá uma sensação de poder muito boa.

Eu não consigo ver competências individuais, acho que as competências coletivas são aquelas que meIhor representam o pulsar dos sonhos, desejos crenças, projetos, habilidades. Não sinto necessidade de desenvolver habilidades individuais, sinto necessidade de desenvolver habilidades coletivas, integradoras, complementares, com cumplicidade.

\section{Entrevista E-02}

\section{1-Como ocorreu sua capacitação para ser docente de enfermagem e quais competências julga que desenvolveu?}

Bom, eu saí há 25 anos exatos, 25 anos e meio, há 25 eu estou na PUC. Eu vim da USP Ribeirão para a PUC. Lá, já notaram que eu tinha um vocação para a docência, tanto que eu vim com uma carta da minha professora de lá, da Cecília Puntel, me encaminhando para a Unicamp, para ser docente, e eu saí com habilitação em saúde pública. Quando eu estava no colegial e no ginásio, eu trabalhava como docente, não de enfermagem, mas dando aula particular para vestibulinho, curso de admissão e para entrar no colegial, porque o colégio do estado já tinha isso, e minha mãe era professora. Quando eu estava no quarto ano da faculdade, eu já organizava na habilitação, eu já fui coordenadora de curso de capacitação de funcionário, que seria educação continuada. Agora, eu não tive capacitação pedagógica, porque eu não fiz licenciatura. Então eu entrei aqui e eu nem sabia fazer um planejamento didático. Eu aprendi aprendendo, não havia quem nos ensinasse aqui dentro. Aí, essa escola aqui, na época, tinha algumas assessorias, na ocasião. Então às vezes vinha professor dar didática que vinha de fora e eu me lembro que a Maria Eugênia foi uma figura muito importante prá nós na ocasião, a própria $\mathrm{D}$. Leonizia que era Diretora, que tinha algum conhecimento, não sei te dimensionar quanto. Eu comprei livros de didática, a PUC oferecia cursos, porque era época de discussão do projeto pedagógico da universidade, e aí, coincidiu também da enfermagem estar num movimento, não sei te pôr em datas, mas nesse momento aconteceu o curso de larga escala também para enfermeiros e a gente foi fazer o curso de capacitação pedagógica e eu entrei aqui dando aula em educação e saúde; aí que eu fui me aproximar desse processo de como aprender e como ensinar e de algumas práticas pedagógicas, mas foi de uma maneira completa- 
mente empírica que eu aprendi a ser professora, mas muito eu já tinha de vocação. Se eu te disser o que eu prefiro ser, enfermeira ou professora, eu te direi que pode ser que seja os dois, mas que eu seria professora em qualquer profissão que eu tivesse; se eu fosse advogada eu seria professora de direito, se eu fosse engenheira, etc, etc,. Não teria outra profissão. Por uma vocação que eu acho que herdei da minha mãe talvez! Nesse período, eu acho que desenvolvi... porque aqui tem duas modalidades de aula; na modalidade de estágio, como eu sou sanitarista, eu tinha um maior preparo eu creio, é claro que você tem que estudar mais, as dificuldades que se apresentam, essa relação professor/aluno no cotidiano, ela envolve algumas coisas que você deve aprender...assim, mas eu acho que eu sou infinitamente melhor, mas eu tinha mais facilidade, talvez alguma dificuldade na hora de fazer avaliação, de eleger critérios subjetivos. Agora, enfrentar uma classe de 80 alunos, como a gente faz aqui, tem que desenvolver certas competências, que eu não sei se são de professores, de um circense, de um juiz (risos), de um árbitro, eu não sei bem o que são! De um condutor de platéia, então alguma coisa de domínio, de disciplina, de disciplinador vamos dizer assim, não bem de professor; de disciplinador, de saber como lidar, sem desrespeitar o modo que a gente acredita que seja o ensino, respeitoso para com o aluno e 0 ensino transformador verdadeiramente e trazendo esse aluno cada vez mais difícil, que não aprende limite na própria casa, nas outras que freqüentou e etc., para se alinhar dos limites das convivências e coisas assim. E essas, eu acho que nenhuma escola ensina, então, eu acho que nem o meu mestrado, nem o meu doutorado me ensinaram a dar aula e nem a escola contribui para isso, eu acho que a escola não me ajuda a fazer isso, a Instituição não me ajuda. Nós somos muito solitários na nossa prática docente, eu sinto assim.

\section{2-Como você percebe que ocorre sua capacitação hoje e quais competências julga estar desen- volvendo?}

Minha capacitação hoje, é de dois jeitos: a pessoal, é muito por interesse intelectual meu. Existe a internet, formas de acesso, banco de dados , consultas on-line, muita informação. Então essa formação, ela vem até você, quer você queira, quer você não queira. Então hora ou outra você se depara com alguma coisa para ler, com alguma coisa para fazer, para escrever, o modelo de escola...outro dia eu estava lendo um livro e um cara que abriu uma escola em São Paulo que chama Lumiar, uma escola de ensino fundamental que a escola não tem classe, o ensino é completamente informal e, eu queria saber como eles tinham grades escolares, como obedeciam ao MEC e eu não conseguia entender porque isso não estava escrito, mas até de novas metodologias de ensino, ou coisas da minha área ou coisas da minha profissão, de política, porque isso tudo te faz professor: filmes que você vai ver, música que você vai ouvir, conversas que você tem... Agora o campo, campo de trabalho, o campo de estágio, também suscita que você procure adquirir competências para poder ensinar os alunos; é discussão de caso, problemas que aparece para você, complexidade da realidade, do cotidiano, então, isso te instiga demais. Por outro lado, tem uma coisa muito desanimadora que você não pode se deixar levar: outro dia na classe uma aluna não sabia o que era diletante. Fui dar aula de epidemiologia, estava contando a história da epidemiologia e a aluna perguntou por que estou aprendendo isso? Por que você está aprendendo história? Por que você acha? Por que você está aqui? Porque que a sua profissão é assim? Porque se você não aprender história, fica muito complicado! Mas você por favor pergunte à professora Silvia que me sucede, por que ela põe as pinças de um jeito, e na hora da operação põe de outro? Você tem idéia por que faz essa pergunta para mim? E Para ela você faz? Ou por que você abre a seringa de lá para cá e não daqui para lá! Por que que eu sou privilegiada?

Aí eu comecei jogar com umas coisas para eles responderem. Não estou ensinando isso para vocês por diletantismo, e a aluna disse: eu nem sei o que é essa palavra!? $E$ eu falei e dicionário vocês sabem?(risos) Então, é uma coisa assim que parece que eles não têm a curiosidade que a gente tem, ou que deveriam ter. Mas assim... eu me sinto muito instigada, mas eu nunca sei o que estou desenvolvendo, então é muito estilo isso, eu não sei se estou desenvolvendo uma dada competência você entendeu? Agora eu sei fazer isso, agora eu sei fazer aquilo. Para algumas coisas sim é óbvio, por exemplo: vou te dar uma questão bem técnica: ontem à tarde eu tive que retomar uma coisa de ter que fazer bota de una, que fazia 25 anos que eu não fazia, essa semana no centro de saúde que eu estava, tive que embrulhar um chumaço de algodão, que não tinha lá. Eu tive que lembrar como fazia isso. É uma coisa que sempre veio pronta na minha mão e eu aprendi a embrulhar na faculdade, que depois de 20 e tantos anos como enfermeira de posta de saúde, eu fui ensinar funcionário a embrulhar. Eu memorizei. Mas assim, é muito intuitivo, eu não sei que adquiri tal competência, mas eu sei quais competências meus alunos estão ad- 
quirindo noto no dia a dia ou no final do semeste, isso para mim é muito gratificante, principalmente porque eu tenho a felicidade de lidar com alunos de quarto ano; isso é uma experiência muito feliz.

\section{3-Como você pensa que deva ser a continuidade desta capacitação e quais competências julga que ainda deva desenvolver?}

Olha! Eu estou perto de me aposentar eu penso! Eu gostaria futuramente de dar aula num curso de pósgraduação e competência... você acha que paciência é competência? Acho que paciência, o exercício da paciência, o exercício da alteridade, o exercício cada vez maior da paciência porque lidar com o jovem, para mim, é cada vez mais difícil; eu não tenho dificuldade de geração, não me sinto assim; não me sinto uma pessoa velha criticando a nova geração, até porque um dia eu fui a nova geração que estava lá numa escola completamente retrógrada. A minha escola era muito retrógrada, mas eu acho que isso é um desafio que ficou aí para nós. Então como é que a gente vai inventar o ensino que vai suscitar o desejo de aprender nessa juventude que vem aí. Na minha escola existia uma apostila e é verdade eu não estou mentindo, todo o ensino de enfermagem fundamental era estudo dirigido; então se fazia aquela apostila e era para uma determinada aula. Tinha uma apostila que era para ditar como se portar, ou seja, a cor da unha a cor do esmalte, a cor da calcinha, a largura das pernas das calças, o comprimento do avental, a barra da calça para o sapato, e isso ficou muito pesado para mim, foi uma vivência muito pesada; eu tinha vontade de sair da escola diariamente. Eu cheguei para minha mãe e disse que queria sair daquela escola e como minha mãe não gostava que eu fizesse enfermagem, na minha casa foi uma hecatombe quando eu entrei na faculdade, porque achavam que era uma profissão muito indesejada para uma menina de boa família e de boa escolarização, e... saía mesmo! Eu... mesmo o processo de inserção no hospital foi muito sofrido, era muita rigidez, muita braveza, agente não podia sequer conversar com um médico na hora do intervalo; é lógico que tinha uma intenção de paquera naquela hora, mas não era nada acintoso, era algo inocente. Eu lembro que o primeiro paciente que eu dei banho, ele morreu no outro dia, eu dei banho de leito em um paciente que estava gravíssimo. Não havia essa preocupação conosco. Eu tenho um amigo que deixou a faculdade justamente quando entramos em fundamentos, porque ele não se sentia preparado para aquela escola, ele andava de sandália, ele não tinha higiene, assim... enfim. era uma formação muito muito rígida. Eu conto para as minhas alunas até hoje, o quanto a gente reparava nas enfermeiras do hospital e dos centros de saúe que eu ia, se ela andava de sandália... por que? Eu fui ensinada a andar de sapato! Não sei se hoje isso é o mais ou o menos importante, mas desconstruir tudo isso foi muito difícil para mim, e até hoje os meus alunos falam e olhe que eu não sou esse tipo, eu não faço esse gênero, porque eu sou absolutamente neurótica com limpeza, com coisas organizadas, tudo limpo, com o ambiente, com tudo e... isso tudo é resquício de uma... então eu acho que a gente tem que passar essa fase de uma enfermagem tão sofrida. Quando eu vejo nossos alunos de piercing, ou coisas assim, às vezes eu me choco, mas eu digo: bem, deixa ela serem felizes do jeito que elas são aí, todas. Então eu acho que é isso que a gente teria que desenvolver como competência, poder estar ensinando de forma mais aprazível, poder estar ministrando de forma mais aprazível eu tenho pensado muito nisso, ensinar dessa forma em qualquer nível. Agora para essa competência eu não sei.

\section{Entrevista E-03 \\ 1-Como ocorreu sua capacitação para ser docente de enfermagem e quais competências julga que desenvolveu?}

Bom Inahiá, como é peculiar da minha pessoa, eu não vou dar conta de te falar de maneira tão pontual. Eu certamente preciso fazer quase que uma revisão histórica mesmo, quer dizer, como que eu chego na enfermagem, como eu consigo pegar talvez um primeiro contato com essa idéia de docente e que certamente tem muito a ver com o estar hoje na docência. Eu fiz um curso de ensino médio, eu fiz o técnico de enfermagem em 78 e quando eu fiz o técnico de enfermagem em Jundiaí, que é uma cidade industrial sem muito desenvolvimento até então na área da saúde, nós tínhamos inclusive professoras que tinham se graduado recentemente e até algumas que não estavam graduadas mas que já davam aulas para nós, pela carência possivelmente da cidade em não ter o profissional para isso. Eles davam uma oportunidade pra gente, que quando você estava no terceiro ano do colégio, você tinha a possibilidade de fazer monitoria com os alunos do segundo ano, junto com o professor mesmo, acompanhando em campo, estágio, em laboratório, o desenvolvimento das habilidades dos alunos. Eu já aí me interessei por essa questão de poder compartilhar mesmo, aquilo que já tinha passado, me capacitado de alguma forma. Esse desejo mesmo, por isso que te falo, preciso recuperar, porque para mim este é um ponto principal que me trouxe 
possivelmente agora, estar na docência em enfermagem. Eu tinha muita clareza quando fiz o colégio técnico, de que eu queria fazer mesmo enfermagem, eu queria ser enfermeira. Tinha a influência muito grande de uma das professoras que tinha estudado aqui na PUC, trazia a gente para ver os cursos em Campinas então pra nós, imagina...sair de Jundiaí para vir a Campinas fazer curso...para nós já era alguma coisa que eu tinha mesmo e achava que era, o curso para me qualificar. Então eu tive esta experiência que foi muito interessante, e a partir disso, com essa clareza, eu fui buscar a minha graduação. Eu fui fazer o técnico porque à época, no país você tinha um incentivo a fazer o curso técnico, como está hoje novamente, até por conta da falte de...certeza de que você ia fazer um curso de graduação e por eu não ter esta certeza, optei por fazer um curso técnico. Eu queria colocar então aí, acho que um marco dessa trajetória para chegar. Quando vim fazer minha graduação, no curso de enfermagem propriamente, não tinha ainda monitoria, no curso, da área do saber dominante, de enfermagem mesmo. Mas nós tínhamos para a área que era considerada básica, essa possibilidade e eu novamente me inseri numa monitoria, que foi de patologia e hoje eu fico... a procurar entender isso, mas era a única possibilidade e eu fui e fiz a minha monitoria em patologia. Então, quer dizer sempre buscando essa possibilidade. Quando me formei eu tinha um desejo grande de ficar em um hospital universitário, um hospital-escola, até por conta de poder verdadeiramente ficar vinculada a essa coisa de sempre estar em movimento com o aprendizado e assim... como primeira opção, nem foi... eu tive uma proposta em Jundiaí para eu voltar e foi muito interessante que minha mãe quando...eu fui lá na Casa de Saúde da cidade para poder ver, tudo, mas buscando aqui em Campinas alguma coisa querendo aqui no hospital, mas o hospital universitário da Puc, ele tinha um esquema de ainda ter poucos enfermeiros e fazendo só aquele esquema de supervisão de vária unidades, das áreas, eles não tinham abertura ainda para enfermeiros em todas as unidades. Isto foi em 86, eu me formei em julho de 86, que foi o último ano de três anos e meio o curso, que a gente tinha ainda aquela modalidade de habilitação, que na verdade fiquei cinco, seis meses de habilitação em médico-cirúrgica, então vou retornar nisso, que deve ter um sentido de qualificação. Mas enfim, daí minha mãe falou: não, acho que você tem que tentar em Campinas ou até mesmo em São Paulo, porque eu vejo o teu desejo de querer estudar, de querer continuar e me preocupa você de repente ficar em Jundiaí, uma cidade ainda muito pequena e "morrer" aí, uma enfermeira de Casa de Saúde de Jundiaí. Isto foi uma coisa muito interessante, porque você imagina, o que toda família quer né? A volta para casa, de alguma maneira. Eu acabei por fim tentando, buscando e surgiu uma oportunidade, no hospital universitário aqui mesmo da Puc; eu sou formada aqui e acabei vindo trabalhar. Quando eu fui trabalhar, lógico, por ter aluno o tempo inteiro passando no campo, eu fui trabalhar numa área de moléstias infectocontagiosas e lógico não me sentia preparada para uma área tão específica, então eu lembro que a gente tinha primeiro os próprios alunos graduandos de enfermagem que passavam com a professora e a gente tinha uma boa relação, eu tinha uma boa relação com a professora, então a gente trocava muito...meio que quando ela chegava ao campo, quer dizer quem que você acha que poderia...estar interessante para os alunos e você acabando quase que ajudando nesse processo também, embora tendo a responsabilidade da unidade. Eu digo Inahiá que eu fui muito feliz no início da minha carreira, porque essa área ela reunia uma equipe de profissionais médicos e eles tinham muita clareza dessa necessidade da gente se inter-relacionar, quer dizer cada um no seu aspecto profissional e nós tínhamos mesmo... as visitas que a gente fazia diariamente, que já era nessa época o médico, a enfermeira, então que eu passava de manhã com eles, tinha um nutricionista e um farmacêutico, e a gente passava essa visita, assim de parar, e havia essa exigência, que era você ter que dar a conduta da tua área e foi quando eu me vi com a necessidade imensa de estudar, de me aprofundar nas questões; eu voltei algumas vezes para a sala de aula mesmo, tanto do curso de enfermagem, quanto do curso de medicina, porque a médica responsável era uma pessoa muito aberta e me convidava inclusive, para ir trocar experiências com os alunos da medicina, então eu digo que fui muito feliz, do ponto de vista de conviver inclusive, não só com o aluno de enfermagem, mas também com 0 aluno de medicina, porque ele passava visita junto com a gente também. $E$ aí você tinha que tomar qual era a conduta de enfermagem. Então eu tinha essa necessidade de voltar, estudar, me aprofundar muito mesmo e sempre numa possibilidade de que era assim: cada vez que começava um grupo novo tanto da área de enfermagem que já era muito comum, a professora vinha, apresentava, a gente apresentava a unidade, mostrava todo aquele parecer do que era a rotina lá, até para as pessoas poderem se localizar e proceder de forma adequada dentro da unidade. 0 que começou a acontecer, foi que com os alunos de medicina, a gente começou a ter o mesmo procedimento. Então quando vinha grupo novo de internos, vinha um grupo novo de residentes, a gente tinha esse papel de passar todas as questões, fazer as trocas, delinear e eles chamavam com muita tranqüilidade então, todo o tempo foi um 
processo mesmo de compartilhamento, que dizer do que eu sabia até então e a isso eu atribuo mesmo, que era toda uma forma, não que eu estivesse já com uma idéia de que eu iria vir para uma área de ensino, mas certamente estava muito embutido, muito inserido em mim porque eu tinha esse processo com muita tranqüilidade, talvez como se eu tivesse me preparando mesmo. 0 que acabou acontecendo na seqüência, eu acabei trabalhando nessa área na unidade de internação e na seqüência fui trabalhar na comissão de controle de infecção hospitalar e aí abriu um leque enorme, porque eu me vi me relacionando com vários outros profissionais que eu noção tinha um contato mais próximo, como o serviço de higiene, o serviço de lavanderia, com o serviço de laboratório; então o que acabou acontecendo, isso ampliou muito a minha visão e os meus contatos e o foco era o papel educativo, na comissão do controle de infecção, porque como a gente tinha uma funcionária que fazia toda aquela parte de coleta, de registro, então o meu papel era mesmo esse tipo de coisa, era medializando e à época, eu estava fazendo paralelamente o curso de administração hospitalar, que previa que a gente tivesse contato com todos os serviços então, ampliou mais ainda, pois eu fui até para o serviço de prontuário de paciente, fui fazer contato com o serviço social enfim, era como se eu conseguisse visualizar aquela estrutura de uma outra forma e conseguisse atuar muito nesta questão educativa. Eu vejo isso como todo um processo importante, que ainda que eu não tivesse clareza que eu ia chegar mas talvez eu estivesse percorrendo esse caminho sem saber que eu iria chegar à questão da docência. Aí, depois que eu fui por um processo de integração com a faculdade de enfermagem, eu e uma professora montamos a proposta para o setor de educação continuada que ainda não tinha. $O$ hospital não tinha, o serviço de enfermagem não tinha. Esse foi um processo mesmo de seleção que houve no hospital e eu passei. Então o meu vínculo com a escola sempre foi muito grande. E com esse projeto de educação continuada e eu vou cada vez mais me aproximando desse processo de ensino/aprendizagem. Quando eu chego a fazer a montagem da proposta com a docente, neste momento, houve uma mudança importante na estrutura organizacional do hospital e eu fui então convidada a trabalhar no gerenciamento do serviço de enfermagem, que a princípio eu resisti porque lógico, tendo sido enfermeira de uma unidade de internação, enfermeira da comissão de infecção e marcando o início do setor de educação continuada, entendia que precisava de experiência e enfim, a escola como tinha essa proposta de integração colocou alguém junto, uma docente para poder assessorar diretamente e para poder desenvolver esse processo comigo e me preparar. Quando eu vou para esse cargo,essa função que é mais administrativa, lógico que eu tenho um afastamento de algumas questões ,mas que amplia demais a relação com a escola que amplia demais as negociações e a responsabilidade de tentar tornar o hospital universitário como realmente um hospital universitário, então lógico que para isso eu me vejo envolvida em reuniões com escola para poder discutir também como que o serviço contribuiria com a formação, enfim, continuo envolvida com as questões do ensino por traz disso, isso foi em 89 , quando chega em 91 , dois anos depois ficou interessante porque quando eu entrei Inahiá, eu disse que ficaria dois anos e não mais que isso, e todo mundo lógico não me falou na hora quem faz uma gestão em dois anos, não dá tempo de começar a respirar e você já ta saindo.Depois de dois anos em 91 surge uma oportunidade na escola, na área de administração de enfermagem, as pessoas entenderam você tem toda possibilidade,são poucas horas vai para você conciliar certamente com a função do hospital, embora tivesse feito essa previsão eu estava muito envolvida, e assim, sabendo que aconteceria muita coisa pra poder começar a dar certo, e na época o superintendente quando eu fui conversar que eu tinha interesse, ele disse que sabia o que iria acontecer, você vai para a escola e não vai querer ficar aqui, e me comprometi que eu iria manter, até porque eram poucas horas,mas enfim, me vi com esse desafio, na época já havia uma exigência que tivéssemos e eu já tinha uma especialização, mas o ideal seria que eu estivesse inserida em um curso de pós-graduação ou de mestrado, pensei que não fosse conseguir, mas a PUCC estava começando um curso de mestrado em educação e eu entendi que teria que fazer em educação, pensei como eu vou para área de docência, eu tinha licenciatura que fiz durante a faculdade, mas era insuficiente, então fui fazer minha inscrição, ao mesmo tempo que eu estava sendo selecionada aqui pra escola eu estava sendo selecionada no curso de mestrado, porque eu entendi que precisava ele iria me ajudar muito como me ajudou, ampliou muito minha visão, de ver um contexto porque a área de concentração é de ensino superior..... para trabalhar com planejamento em educação, porque até então eu sabia trabalhar planejamento em serviço não para educação, então foi muito rico eu sinto que foi um momento importante para a minha capacitação, porque agora sim eu iria me formar docente de um curso de graduação, então passei pela seleção, passei aqui porque tinha mais um candidato, mas ele acabou não vindo foi um concurso público, foi uma questão interessante porque teve um professor da faculdade que era de uma outra área e era uma pessoa que eu não tinha muito contato, inclusive porque ela era da 
área de saúde coletiva, teve uma professora da TO que veio participar porque era concurso público, e veio uma pessoa de fora uma enfermeira da prefeitura participar da minha seleção por conta do concurso público, e aí paralelamente eu fiz também a seleção e acabei sendo aprovada nos dois porque a escola entendeu que eu já estava na verdade buscando.... e estavam confiantes que eu iria passar mesmo e passei. Então eu conciliei um pouco o gerenciamento do serviço, foi muito pesado eu demorei muito para fazer o meu mestrado e hoje eu vejo uma aceleração na questão do mestrado, fiz em muito tempo até porque não existia isso na época e também porque eu estava no hospital e não tinha como fazer a disciplina muitas vezes à noite, porque o curso tinha essa possibilidade no mestrado de educação.... capacitação no sentido de estar especificamente, até quando eu fui prestar o doutorado, onde você faz, na USP eu lembro que a banca fez uma análise do meu currículo olhando para isso desde o técnico eu já participava de todos os eventos que eu podia e durante a faculdade, depois que eu fui para o serviço, era um contínuo não haviam quebras e lógico que voltado a cada momento do que eu estava fazendo eu ia me capacitar naquilo que eu estava trabalhando mais de perto, então eu me lembro que foi feita uma análise e é interessante que você mesma nem percebe porque se torna tão cotidiano você procurar essas coisas, hoje eu falo muito para os alunos que o período de segunda à sexta é muito complicado, porque muitos cursos acontecem nos finais de semana e que precisamos nos propor também à isso, porque senão você perde. Então eu acho que a minha capacitação para docente de enfermagem, quando eu chego para a docência ela tem esses episódios, esse marco no técnico essa continuidade na faculdade, uma vida profissional em um hospital universitário que me exigia esse tipo de coisa, e que para mim não era uma exigência doida, era uma exigência prazerosa, pois eu tinha prazer em fazer isso, então o marco mesmo da capacitação no mestrado na área de educação especificamente me dando.... eu reconheço isso, eu fui com essa proposta e reconheço que me capacitei muito para isso.Lógico que na continuidade Inahiá eu fui depois fazer o doutorado,embora tivesse um indicativo de eu continuar na educação, a banca fez uma indicação que eu teria tudo para continuar na área da educação já tínhamos um doutorado na UNICAMP, de educação, mas eu tinha um desejo muito interno de voltar para a área da enfermagem, eu dizia tudo bem eu acho que é importante, hoje acho que é importante não me arrependo e que devia ter voltado mesmo, mas também se tivesse ido para a educação eu acho que teria aproveitado, absorvido até porque é uma coisa que me chama a atenção, sempre tem alguma coisa em termos de capacitação nesse sentido e eu fico super aguçada de querer estar indo, mas achei que foi importante porque comecei ver vinculado essa questão do ensino mesmo dentro da área que eu escolhi, que eu gosto e tenho certeza que era o que eu tinha que fazer. Fiz também meu doutorado, tudo isso me capacitando, mas acho que deveríamos colocar esse divisor quando eu chego para docência porque a primeira questão, a minha capacitação para ser docente de enfermagem, então para mim chega até aí, daí eu me torno docente de enfermagem, o doutorado vem já enquanto docente na seqüência, embora o mestrado paralelo também, então acho que fica dessa forma. Penso que naquele momento desenvolvi competências técnicocientíficas relativas a área de enfermagem em aspectos não só assistenciais, mas gerenciais e educativos, sendo que estes últimos certamente promoveram a condição para na seqüência, enquanto profissional já desenvolver junto à equipe de enfermagem questões educativas, bem como a presença de alunos de graduação da área da saúde também estimularam o colocar em prática este aspecto educacional.

\section{2-Como você percebe que ocorre sua capacitação hoje e quais competências julga estar desen- volvendo?}

Bom Inahiá, a capacitação hoje embora não seja de maneira tão formal, é diferente você estar em uma estrutura formal, você fez uma especialização, faz um mestrado, faz um doutorado, eu falo que a gente fica meio órfão depois que a gente.... é como se, agora você se tornou independente e eu vejo que é um desafio para você continuar fazendo alguma coisa, mas eu sempre tive isso muito presente, tenho muito medo de ficar desatualizada, de repente uma professora que não sabe nem o que está acontecendo, então se está sempre correndo, eu acho que hoje tem algumas coisas que eu posso colocar, acho que na medida do possível continuo saindo, hoje estou com uma clareza, eu comecei nos Congressos Brasileiros de Enfermagem à delinear o que eu ia fazer lá, e o que eu ia fazer lá era para ir nas reuniões das escolas, para ir ver os trabalhos de cenas maiores e o que estive voltado à educação é o que sempre me chama, até então, afinal estou na área de ensino e aí tenho que estar. E por meio dos Congressos descobri o seminário nacional de ensino das diretrizes de ensino de enfermagem FENABEM, me encantei na primeira vez que fui, me encantei nesse sentido porque entendia que lá é o fórum, lá é 0 .... onde acontecem algumas discussões importantes para área do ensino e hoje até priorizo em relação ao próprio con- 
gresso, até porque às vezes não é possibilitado você sair, ou com as reposições que tem que fazer ou economicamente às vezes não é tão possível, então eu tenho me vinculado à isso, já participei e esse ano devo ir novamente no seminário de pesquisa em enfermagem, porque dentro da graduação eu trabaIho com a área de pesquisa também orientando, então eu acho que é importante para ver o que se está discutindo, então continuam as capacitações em termos de eventos que eu vá, direcionadas. Reuniões de escolas de enfermagem, então vão para as reuniões de escolas de enfermagem porque é aí que se discute a questão de ensino de enfermagem, eu vejo isso como uma capacitação, uma questão importante para continuidade ou para como minha capacitação ocorre hoje a própria questão de estar na docência, o próprio aluno te instigando a todo momento, te perguntando, e hoje um aluno muito diferente com uma abertura outra, então às vezes abre a Internet e vê uma coisa e trás e quer compartilhar com você, então ele também provoca essa capacitação contínua, aliás ele é um teste, outra questão é fazer parte de uma comissão de avaliação de projetos pedagógicos dentro da escola é uma coisa que exige muito de você estar mesmo inteirado com tudo que está acontecendo e não é só na área de ensino de enfermagem, é na área educacional até porque a gente começa a conviver com outras comissões de outros cursos da área da saúde nessa tentativa de tornar as questões mais coletivas, mais socializadas, isso acaba te estimulando tendo que buscar e você acaba muito atenta à todas questões inclusive de capacitação pedagógica, então a universidade agora deve começar oferecer de maneira mais contínua e eles estão com um programa permanente de capacitação pedagógica, mas eles já tem oferecido algumas coisas e dentro do possível eu tenho participado, então vou, já fui em congresso em curso de capacitação para docente, pedagógico, então aproveito, muitas vezes há dificuldade de sair, mas sempre encontro um jeito, reponho ou faço de outra forma e também internamente a faculdade tem oferecido e esse também é um outro ponto e vários outros, mas um ponto que eu atribuo com muita importância e nós mesmos já discutimos, não é Inahiá? .A importância de ter no grupo que você trabalha mais de perto que é a disciplina de administração de gerenciamento..... capacitação, então eu me vejo trabalhando com três pessoas, uma no mestrado e duas no doutorado, então é assim, a todo momento estou recendo; li esse artigo achei interessante, teve uma aula, as pessoas querendo compartilhar e eu fico pensando que preciso também ler isso preciso me aproximar e sempre com a sensação que estou ficando atrasada e acho isso tudo estimulante, é na verdade o que mobiliza internamente, que te motiva a estar buscando, esse também é outro ponto, então eu não consigo te dizer de forma quadradinha como ocorre sua capacitação, porque do ponto de vista formal eu não sou vinculada a um curso único, tenho feito curso de extensão, mas tenho visto em todas assas coisas que se acontece agora todo um processo que tem me capacitado ou que tem dado facilidade a minha busca de capacitação. E uma outra questão desde que terminei o doutorado é que estou continuando com o meu projeto, do que eu discutia e continuo inserindo sempre a questão de alunos de iniciação científica, nós temos o programa institucional de iniciação científica, porque como eu não sou professora de regimes de dedicação eu não tenho como fazer o pedido para órgão, mas internamente a universidade tem esse programa e eu tenho conseguido manter por também ter alunos, que é outro estímulo, então eu poderia Ihe dizer isso Inahiá, eu percebo que a minha capacitação hoje ocorre por todos esses estímulos que eu continuo tendo e mais o desejo e a clareza da necessidade disso acabo agoniada por não dar conta de ler tudo o que eu gostaria por ter outra carga, mas ainda bem que estamos no ensino o tempo inteiro com a possibilidade de ir à biblioteca, vai com o aluno e aproveita também, acho que é isso. Humm.... Penso que nesta etapa tenho realizado auto-avaliação constante do meu trabalho e a busca de aprimoramento na área educacional e/ou de enfermagem, quer por meio de participação em eventos científicos internos ou externos à Universidade, têm proporcionado a aproximação com a questão de práticas pedagógicas e avaliação de ensino-aprendizagem.

\section{Como você pensa que deva ser a continuidade dessa capacitação e quais competências julga que ainda deva desenvolver?}

Bom, para responder essa terceira pergunta em primeiro lugar entenda o que eu vou dizer, não é que eu esteja me sentindo velha, não é isso,eu estou num momento da minha vida que é pessoal também e lógico que tem à ver profissionalmente não se separa essas coisas, eu estou em uma fase muito especial mesmo, que sinto que é do amadurecimento e sinto que é depois dos quarenta, é um marco, tem uma coisa diferente .Inicialmente no campo profissional o que eu tenho feito aqui na escola que é o meu lugar maior de trabalho, eu sinto como já te falei, que na minha capacitação a continuidade se deu e vai continuar se dando enquanto tiverem essas pessoas no grupo ou em capacitação ou com essa vontade e desejo de também continuar se atualizando e vendo que isso é de suma importância para a docência, mas 
paralelamente eu tenho um momento que é um momento de querer mesmo ver nessas pessoas, a continuidade, por isso que eu falei, entenda, eu não estou me achando velha e nem amadurecida, mas precisando fazer algumas outras coisas. Então eu tenho tentado na medida do possível até porque eu sou muito centralizadora , sistemática com as coisas e por um período, sozinha na área, isso também me fez ficar com visão de tudo, porque tinha que dar conta, mas essa idéia de compartilhar para ver a continuidade mesmo, já tive uma fase aqui há quatro anos que eu tive medo de ir embora daqui, tive uma oportunidade e tive medo porque eu entendia que a área de gerenciamento ficaria acéfala não porque eu ia, mas porque eu era a única dessa história da área de gerenciamento que iria embora, e falei não, eu não posso fazer isso com a enfermagem, com área de gerenciamento com as coisas que eu gosto e fiquei.Hoje eu fico emocionada e com tranqüilidade se tivesse que ir para uma outra oportunidade e tranqülidade de saber que tem pessoas para continuar e eu acho esse amadurecimento importante..... para outras capacitações, sabe quando você se sente com a possibilidade de compartilhar outras coisas talvez em outros focos, inclusive tenho falado que a minha vida vai mudar, ontem brinquei com uma professora "espera que semestre que vem a minha vida vai mudar", vai mudar por conta disso eu estou tentando gerenciar o que eu vou realmente fazer, agora eu vou me capacitar em uma outra coisa, eu sempre tive o desejo e tenho tido dificuldade por ter que trabalhar muito, a gente trabalha demais..... e eu preciso dessa capacitação, dessa qualificação de socializar um conhecimento que eu vejo que vou acumulando, acumulando e não que eu me ache com muito conhecimento, mas eu tenho um acúmulo em algumas coisas que eu precisava socializar e não tenho encontrado espaço para isso, para esse caminho, então isto é o que eu vou continuar fazendo, a minha continuidade eu não vou deixar logicamente as minhas coisas, que eu tenho feito, o contato com o aluno eu acho que é importante, mas poder me capacitar nessa outra questão que é de produzir conhecimento, mas socializar, porque eu vejo que tem muita coisa que você vai estudando, às vezes aqui na escola você orienta inclusive trabalho que não é da área de gerenciamento, então você vai aprendendo muita coisa, você busca até naquilo, o tem lá de gerenciamento e é interessante porque os alunos ficam altamente envolvidos com essa possibilidade e também querem encontrar. Então eu sinto que a minha continuidade vai ser nisso, eu vou continuar saindo para esses encontros que discutem a questão, ontem eu fiquei sabendo por uma professora, que eu nunca fui no evento da Rede Unida mas é um evento super importante que discute a questão da área de formação de profissional da área da saúde que discute essa vinculação do Sistema Único de Saúde e acho que é uma coisa que a gente tem que ter clareza, inclusive desse papel nosso de cidadão, de docente, como temos passados isso para nossos alunos, a quantas anda o compromisso social da enfermagem,quer dizer, eu tenho dúvidas das lutas do que está sendo feito e só tenho clareza disso por estar no convívio,mas tenho me questionado muito, 0 que a gente tem feito enquanto docente, bem ou mal quantos alunos passam pela gente, como temos discutido essas questões com os alunos. Até ontem saiu o resultado do ENADI para todas as escolas, e troquei com alguns professores e todos acharam uma colocação mediana apesar de trabalharmos bastante, e eu disse que acho que devemos repensar muita coisa.... competências que tem se discutido tanto, nós ainda estamos muito vinculado à uma competência muito técnica que acho que tem toda sua importância não quero subestimar isso, mas tem outras questões a serem trabalhadas e principalmente essa coisa mesmo da articulação que o aluno tem que fazer com as questões, então eu acho que fica muito esvaziado eu acho que até temos uma proposta bem definida, importante mesmo para a formação, mas temos conseguido pouco alcançar isso, então eu digo que nem estou com essa sensação ruim, até porque tem outros cursos aqui da PUCC tiveram o primeiro lugar, atingiram. Ontem estávamos em reunião com todos os cursos, então você imagina o que isso foi e achei interessante e acho que isso faz parte do amadurecimento, estou querendo entender onde pegou e onde podemos percorrer para poder melhorar isso e também isso representa uma coisa muito pequena, agora o que eu acho que dentro de uma avaliação que eu faço..... Então essa continuidade da minha capacitação embora.....tese... falando desse momento que eu me encontro, mas ele tem tudo a ver. Porque a capacitação agora para mim, veja bem, porque quando você começa a vida você vai para todos os cantos e vai ficando mais seletivo, mas não seletivo no sentido de ficar de criar espaços diferentes, mas seletivo no sentido de direcionar o que você tem que fazer.Então eu acho que a minha capacitação nesse momento que eu vejo que é maior que eu tenha que fazer, é dar continuidade ao que eu tenho feito na minha área de atuação, mas eu preciso socializar.No ano passado uma professora de uma outra escola, pública,falou que preciso por tudo isso no papel, preciso escrever isso, porque tudo o que você falou aqui tem importância para outras escolas que estejam começando tudo mais.....curricular, que é uma experiência que nós temos já aqui. Daí você sai toda empolgada, agora eu vou fazer, na verdade eu sinto que pouco me organizei para isso, por isso que 
eu falo, vai mudar, mas vai mudar em outro sentido porque eu me sinto mais tranqüila hoje de ter as pessoas que podem estar indo à frente, até porque esta é a questão natural da vida, até brinco que quando estiver ficando "gagá" vocês me avisem, não quero só com a aposentadoria é que eu acho que vou fazer alguma coisa, até porque com a aposentadoria que nós vamos ter, mas enfim eu acho que essa é uma questão.

Julgo que as competências de aprimoramento no campo específico da educação, em continuidade às questões relativas às práticas pedagógicas e avaliação, aprimorando neste segundo aspecto a autoavaliação e também a habilidade em compartilhar a avaliação junto àqueles que têm recebido os alunos em campo de estágio.

\section{Entrevista E-04}

\section{1-Como ocorreu a sua capacitação para ser docente de enfermagem e quais competências julga que desenvolveu?}

$\mathrm{Na}$ verdade a capacitação docente ocorreu posteriormente, quando eu já era docente. Eu já trabalhava na faculdade e depois de uns três anos, a PUC começou a oferecer alguns cursos de aprimoramento aos docentes, nos quais eles ensinavam os professores a elaborar, planejar, elaborar provas, desenvolver 0 senso de observação, se relacionar em equipe, então eu lembro que fiz vários desses cursos que eram de curta duração, mas foram muito importantes e me lembro que foram ministrados por docentes da educação da própria PUC. Naquela época isso foi muito importante, pois nos deu subsídios para que pudéssemos enfrentar a sala de aula, porque a gente começou a dar aula sem nenhum preparo, depois que a gente foi se aprimorando.

Neste período eu acho que desenvolvi a competência da interação aluno/professor, a competência do uso de novas estratégias para levar o aluno a uma reflexão holística do paciente no que diz respeito não só da parte biológica, mas também a parte social e política, acho que consegui a competência de estimular 0 aluno à produção do saber, desenvolvi a competência da pesquisa e da observação.

\section{2-Como você percebe que ocorre sua capacitação hoje e quais competências julga estar desen- volvendo?}

A minha capacitação hoje ocorre através do empenho pessoal, através de participação em cursos na minha área, participação em congressos, através de leituras e através dos cursos que a própria PUC oferece. Acho que falta desenvolver algumas competências ainda. Eu teria muita alegria se pudesse colocar em prática a sistematização da assistência de enfermagem, porque eu trabalho todo o embasamento teórico junto ao aluno e eu gostaria de sentir a problemática da prática para saber qual seria a minha capacidade de resolução de problemas. Eu acho que, por exemplo: eu acho que já desenvolvi o problema do trabalho em equipe que eu acho difícil e eu acho que isso iria facilitar para mim na sistematização da assistência, acho que é um desafio, tenho vontade de pôr na prática um projeto piloto no hospital, para gente sentir bem na prática, qual é essa dificuldade tão grande que existe da sistematização da assistência; desde que haja recursos humanos, eu gostaria muito de fazer isso de ter esse desafio. Eu gostaria também de desenvolver a competência de termais facilidade para redação, tenho um pouco de dificuldade em escrever um trabalho científico, de escrever, de colocar as palavras adequadas, todo ano eu estou mandando, mas não é uma coisa tão simples para mim. Eu gostaria muito que na faculdade tivesse um órgão de apoio nesse sentido, um facilitador para isso, que dissesse; isso está adequado, isso esta errado, se seu objetivo está batendo com a introdução, não está batendo, então às vezes eu tenho dúvidas e eu não tenho muito com quem trocar.

\section{3-Como você pensa que deva ser a continuidade desta capacitação e quais competências julga que ainda deva desenvolver?}

Acho que ela tem que ser permanente e o professor deve ser muito estimulado, porque o que eu sinto é 0 seguinte: no início da profissão, quando eu comecei, estava muito estimulada, eu fiz habilitação em médico-cirúgica, especialização em enfermagem do trabalho, terminei e fiz administração hospitalar, depois vieram esse cursos aqui, que eles estavam oferecendo, com o passar do tempo houve uma acalmia, a gente deixa acalmar os ânimos e só depois que comecei o curso de mestrado em educação, que fui me sentir motivada novamente, porque era muito difícil, antigamente era muito difícil a gente tinha que sair para São Paulo, eu estava com criança pequena e neste período não pude investir muito no meu aprimoramento. Quando surgiu o mestrado na área de educação, eu fui da primeira turma, eu fui no sentido de 
realmente estar me aprimorando porque financeiramente ele não me daria nenhum retorno, porque como eu sou uma professora antiga aqui na faculdade, eu já tinha minha titulação, eu era professora titular, então eu fui fazer o mestrado realmente no sentido de aprimoramento de abrir os horizontes e eu achei que foi muito bom fazer o mestrado fora da área de saúde, porque ela me deu uma visão política muito boa da educação, foi fantástico eu gostei muito de conhecer a área de educação. Como foi a primeira turma, a responsabilidade dos docentes era muito grande para garantir a continuidade do programa. Foi muito bom. Agora! Eu acho que precisa a Instituição investir mais no docente porque eu acho muito difícil, não nem o fato de você ter que... ter que pagar o curso que você vai fazer, mas o que me deixa muito chateada é a dificuldade que a gente tem de sair para fazer esses cursos, para trazer o que é bom para aluno, e quando chega aqui não só tem que repor tudo, mas é muito burocrático, o negócio é muito burocrático, parece que ele não favorece nada ao docente e isto é muito desestimulador. O nosso tempo é muito restrito e a gente quer ler quer produzir e como tem tempo isto frustra muito o professor, porque se ele não está na carreira docente, se ele não procurar por si mesmo produzir, ele vai ficando a parte. Como você vai achar tempo para produzir, publicar...porque a carga horária não permite, aqui, se a gente é contratado por 30, trabalha por 45. É isso. Eu acho que a gente está sempre precisando desenvolver nossas competências, só sabe das competências que a gente não desenvolveu, quando se depara com situações e aí a gente vê que precisa crescer mais e a gente cresce todo dia. Hoje desenvolver a competência para o uso da informática por exemplo é necessário e eu tenho muita dificuldade ainda e muitas vezes eu tenho que pedir ajuda para meus filhos, eu tenho dificuldade, mas acho que tenho que ter o domínio mesmo. Agora o que eu tenho sede mesmo é de ver a SAE funcionando porque eu acho que aí ai vou ver o poder da enfermagem. É isso.

\section{Entrevista E-05}

\section{Como ocorreu a sua capacitação e quais competências julga que desenvolveu?}

$\mathrm{Na}$ verdade eu percebo dois momentos bem distintos um do outro, quando comecei a me ver como docente. Eu sempre gostei de ensinar na época de estudante, era uma questão assim, eu vivia ensinando alguém, sendo professora. Em dado momento, até tentei fazer licenciatura junto com a graduação, mas aí, eu achei aquilo muito distante da realidade, muito longe da enfermagem e me pareceu um linguajar que eu não dominava, eu sei que não concluí o curso de licenciatura, mas continuei com a vontade de ser docente e meio que na imitação dos meus professores, aqueles que eu considerava bons e eu ia construindo uma referência do que era um bom professor e aí, praticamente este foi um primeiro modelo; uma questão intuitiva, de repetição, como eu acho que acontece com a maior parte das pessoas, eu não tinha um saber que me sustentava. Era mesmo uma questão de reprodução de práticas que eu achava interessantes, que à época, essas práticas me impressionavam muito pelo rigor técnico, pela clareza didática de explicar os conceitos entendeu? Isso era o meu patamar, era como eu me via fazendo e foi assim que eu me fiz docente, praticamente repetindo esses modelos, procurando um conhecimento bastante grande da área, que eu queria colocar, era bastante fechada na enfermagem mesmo, e a busca de uma clareza da exposição dos conceitos, de exemplificação, etc. A medida em que isso foi avançando, eu fui percebendo que tinham elementos que eu não sentia segurança, embora eu tivesse sempre um espírito aventureiro de arriscar a fazer coisas, mas eu sentia muito medo de não ter base. Aí eu comecei a me interessar, por conta de algumas leituras de...meio que um autodidatismo mesmo, comecei a ler coisas sobre educação e a pensar como é que isso poderia ser aplicado na minha área; isso foi aumentando à medida em que eu assumi a direção do curso, onde questões pedagógicas pareciam ser importantes e eu percebi que eu tinha uma ignorância ali perigosa, ela era boa para mim, ela só encobria minhas necessidades, mas parecia perigosa em relação ao grupo que eu tinha que coordenar, empurrar para algum lado e eu tive...comecei a ter medo. Aí eu comecei, tanto no mestrado e depois no doutorado, a buscar uma interface entre as questões do ensino da enfermagem e a alguns aspectos polêmicos da prática pedagógica, buscar entender, aprofundar. Fiz isso no mestrado, na própria enfermagem; foi um caminho interessante, mas insuficiente. Daí no doutorado, eu fui mesmo para a área da educação e nesse lócus, eu comecei uma nova aventura: lendo, estudando me interessando e aí eu penso que isso me ajudou muito e dentro do ponto de vista formal né? Uma fase que é bastante intuitiva, de reprodução, outra hora que eu me dou conta de que isso não é suficiente, especialmente quando percebo que isso prejudica ou interfere na vida de muitas pessoas e isso me faz pensar também na relação com os alunos. Então, no começo da minha prática pedagógica, eu era tida como uma boa professora pelos alunos, dentro do perfil considerado competente, técnico, e aí, era curioso, porque é uma coisa que eu não entendia de onde vinha, porque eu 
tinha um reforço positivo dos alunos, eles gostavam do jeito que eu dava aula, mas, à medida em que eu fui começando a estudar e a entender isso, eu comecei a perceber que um monte de coisa que nos livros não traziam, nos livros de enfermagem, ou mesmo algumas práticas que eu reproduzia, tinha uma dimensão do humano, das relações que permitiam que eu pudesse me comunicar melhor e comunicar melhor os conteúdos que à época eu queria estar trabalhando. Interessante como muda essa concepção do que seria um bom docente, por um primeiro enfoque, quando eu percebo que aquele modelo que eles celebravam, na realidade ele era limitante e é como se eu fizesse muito mal aos alunos, na medida em que eu estreitava a possibilidade deles verem além. Aí eu começo a arriscar apoiada nesses outros referenciais, na outra prática de docência em enfermagem, que não é tão exitosa, na medida em que ela não é reconhecida pelos alunos, como aula. Então foi muito curioso, porque eu gostava de ver cada vez mais a docente em que estava me transformando e, eu era cada vez menos popular; curioso né? Era um trabaIho muito assim....sofrido porque...parecia que o tempo não tinha sincronia, meu tempo e no tempo deles e isso é quase que um convite a voltar para a prática antiga, mas que resvala na sua outra forma de entender o teu papel. Então você tem que continuar buscando uma competência também para poder tornar aquilo possível para eles. Acho que é isso que eu queria estar reforçando. A gente vai descobrindo na medida em que começa a prestar atenção, atenção primeiro nas pessoas e o retorno imediato que elas me davam e depois comecei a pensar num retorno a médio e longo prazo e aí eu comecei a entender que não é só o aqui e agora, aquela festa, aquela vitória de momento; eu queria outras coisas, passou a ser um desafio.

\section{Como você percebe que ocorre a sua capacitação hoje? E quais as competências que julga es- tar desenvolvendo hoje?}

Acho que hoje eu estou nesta fase de tentar construir essas competências, mais amplas, do conceito do que é ser competente para ser docente de enfermagem. Hoje, como tudo na educação, é um processo; não poderia te dizer olha, agora eu consigo, eu estou satisfeita com isso. Eu percebo que eu tenho uma outra fase que eu colocaria, que é a fase de uma vontade de não ter regras nenhuma. Então aí passo a crer uma prática que é dialogada, respeitosa, ética, e que algumas vezes me leva ao limite quase de ficar frouxo, sem limites, porque eu quero apostar que os alunos aprenderão, então, eu não preciso de recursos mais autoritários, mais diretivos. Então eu percebo que em alguns momentos eu ensaio práticas inovadoras, eu ensaio processos de avaliação mais emancipatórios, mas, eu entendo que chega num ponto em que os alunos não estão aparelhados para isto. Embora eu perceba o esforço enorme de estar cumprindo as competências e alargar horizontes, estabelecer conexão de informações, de conteúdos, estabelecer os diálogos com as diversas áreas, mesmo... a dificuldade que eu tenho para fazer isso...é... eu percebo que eu começo a me perguntar: será que eu estou ensinando? Será que de fato eles estão aprendendo? Será que não é muito...um sonho muito longe do que é possível? Será que para o momento e agora também, eu não estou me excedendo nisso? Então muitas vezes os próprios alunos me fizeram rever isso, quando eles realmente pediam um pouco mais de organização, um pouco mais de controle, é como se eles quisessem ser controlados, por um modelo que eles dominavam melhor e essa coisa que podia me entusiasmar muito, porque eu podia viajar, eu podia ir longe, era muito desestabilizadora para eles e eles não reconheciam, eles não se sentiam seguros de que iam pelo caminho certo. Então eu tive momentos assim de práticas que eu amei profundamente ter feito e o retorno não foi bom e quando eu voltei no semestre seguinte eu já não estava tão entusiasmada em tornar a aplicá-los. Sabe quando você pensa o tempo inteiro: o que é certo o que é errado, para onde que eu vou?

\section{3-Como você pensa que deva ser a continuidade dessa capacitação? E quais competências julga que ainda deva desenvolver?}

Eu acho que hoje o meu desejo seria manter essa linha que eu acredito, trabalhar muito na base dos valores, da ética, do compromisso, de uma aplicação eu diria mesmo edificante dos conhecimentos para gerar atitudes, profissionais mais responsáveis, mais posicionados, mais comprometidos e a possibilidade de uma organização didático-pedagógica que permita que a gente faça isso e que tanto a eles quanto a mim dê a segurança de que alguma coisa aconteceu. Acho que essa organização, eu estou entrando numa fase que estou tentando colocar um pouco mais de sistematização, para mim e para eles, principalmente para mim, porque também eu já não tenho tanta certeza de que esse caos que foi necessário para eu poder romper algumas coisas... é prudente; eu diria que se não tivesse a graduação, em classes grandes, em classes de meninos que não estão muito motivados, ou nem sabendo exatamente do que eu 
estou querendo falar e porque a minha urgência em falar dessas coisas, me causa um pouco de risco, então eu acho que preciso temperar um pouco. Eu acho que estou numa fase, no momento da curvatura da vara: voltando, mas voltando diferente, para um lugar que eu também não quero habitar do mesmo jeito. Você entendeu? Acho que essa competência de uma transposição didática daquilo que permita, daquilo que eu sonho e que é muito amplo e é fluído para eles, de uma forma que eles sintam segurança e vão rompendo no limite deles aquilo que sei lá em quantos anos de profissão eu consegui fazer né? Então eu acho que tenho que dosar isso. Acho que é essa competência que eu estou tentando. Como que estou fazendo? Experimentando. Acho que eu estou na fase que o referencial teórico me dá tranqüilidade, ler, estudar, tudo isso é muito interessante, mas eu acho que estou naquela fase de experimentar na prática para ver onde vai dar. Brincar e fazer sempre a reflexão sobre isso. E para mim não é muito difícil esse processo, porque ele gera sempre um trabalho no campo que estou fazendo hoje, que é a discussão da docência, por conta da mudança né? Como eu fiquei mais hoje professora universitária do que enfermeira, passou a ser um instrumento de trabalho a reflexão sobre essa prática pedagógica, que eu produzo, enquanto aprendo, vamos dizer assim. Eu percebo hoje, numa fase em que eu volto a ser docente, assim... docente no chão da fábrica, você está ali na sala de aula, saindo de uma pós-graduação, voltando para a graduação, eu posso dizer mesmo, sem medo de errar que é um lugar que eu voltei a me encantar, com a possibilidade que você tem nesses pequenos grupos de jogar com alguma coisa; talvez eu diria assim, porque eu fiquei muito ligada a funções administrativas, que talvez a semente mais fértil ainda seja os alunos, porque por meio do que você investe neles, o retorno tem potencial, é uma promessa e eu percebo às vezes que muito do que você fala, faz sentido, não da forma homogênea, mas, faz sentido para alguns deles, diferente do que você as vezes vê, quando você está muito distante daquilo né? Que você fala mas parece que é um discurso que cai no vazio. Acho que para o professor está mais difícil dele encontrar respaldo para essas práticas e 0 aluno, tem momentos que se surpreende com esse acolhimento, com essa disposição, com essa entrega que é a competência. A competência, sabe o que é? É entrega mesmo, está posta no outro, está no desejo que o outro $e^{\prime}$... como posso te dizer... te faça de alguma forma, permanecer, quando tudo já passou sabe? Acho que é isso.

\section{Entrevista E-06 \\ 1-Como ocorreu a sua capacitação para ser docente de enfermagem e quais competências julga que já desenvolveu?}

$\mathrm{Na}$ verdade a capacitação foi ocorrendo com a própria trajetória profissional, acho que é difícil separar as duas coisas. Eu não me formei para ser professora, na verdade aconteceu, eu não tive uma formação na época, a gente tinha licenciatura, mas eu não fiz. Eu fiz a graduação e fui fazer residência em enfermagem, então, a todo momento eu não tinha pensado em me tornar docente. Sempre o que me guiou foi realmente à parte do cuidado, então eu fui buscar a competência para esta prática. Durante essa formação, o enfoque educacional foi surgindo e durante a residência, o próprio curso, você acaba tendo que fazer trabalho, aula e socializar todo esse conteúdo, então foi uma coisa que começou a surgir naturalmente. Depois, ainda na residência tinha um enfoque para educação continuada do hospital e comecei a me identificar muito com o ensino, nessa fase com o ensino de funcionário. Acabei a residência e fiquei alocada na educação continuada, então, foi surgindo, e a minha vinda para a docência acabou sendo muito... acho que posso dizer ao acaso mesmo, eu voltei para a escola, para pedir uma orientação, porque eu mudei, acabei saindo do hospital, eu vim de São Paulo para Indaiatuba e vim para a escola pedir uma orientação profissional, quer dizer, o que eu faço agora, onde eu devo procurar, onde eu devo trabalhar e foi quando na época era a Mara, uma professora de referência que eu vim procurar e ela me disse: por que você não concorre para dar aula! Você tem uma trajetória legal, você fez esse curso, da área, e a gente vai precisar de professor para estágio. Como era para estágio, eu estava tranqüila, porque era a minha prática e o que eu faço, vou gostar, é uma forma de conciliar. Comecei com o estágio, depois aos poucos fui assumindo a teoria e fui gostando muito. Então, não tive uma capacitação formal ela foi se dando pela prática mesmo, com a vivência. Depois, naquela época, a gente era muito feliz aqui (risos), tinha capacitações docentes, tinha um grupo, tinha orientação pedagógica interessante, muita reflexão, então tinha alguns momentos que a gente foi revendo o processo de ensino então eu fui aprendendo com a prática e com esses momentos a gente foi crescendo muito. Daí eu fiz o meu mestrado na área de educação, fui ver a função educativa do enfermeiro, com muitas leituras do aprendizado do adulto, da própria pedagogia e leitura de literatura para a própria tese, fui chegando, fui me enxergando, fui me encontrando e fui me capacitando através disso. No começo foi muito difícil, porque era uma outra área, mas me aju- 
dou muito, com as disciplinas, foi muito bom para a minha capacitação. Nesse período as competências que desenvolvi, acho que teve a competência técnica, acho que fui desenvolvendo bastante a competência política mesmo, do aluno, trabalhando com aluno, é a função educativa do enfermeiro, com o paciente de como a gente pode fazer essa interface, acho que isso aconteceu e lógico está junto toda a competência ética, a gente vai tentando, vai aprendendo essa terminologia e vai tentando se encaixar, fala: pôxa, eu não chamava assim, mas eu acho que é isso o que é.

\section{2-Como você percebe que ocorre a sua capacitação hoje e quais competências julga estar desen- volvendo?}

Eu acho que saí de uma competência, não sei se posso chamar assim, mas uma competência positivista, do próprio sistema de avaliação, isso está errado, ao sabe, vai recuperar, mas o que é essa recuperação, exame; eu vim de uma escola muito positivista e eu vim com uma competência no início aqui, e acho que a gente foi aprendendo, foi crescendo e foi vendo essa condição um pouco mais humanista mesmo, de tentar entender 0 aluno, de compreender esse nosso aluno trabalhador, de ver onde a gente pode motivar, ao invés de cobrar. Eu acho que essa competência hoje, que estou desenvolvendo é muito voltada para essa outra visão não tanto positivista, mas, de construir mesmo, de dividir as responsabilidades, de trabalhar com ele, não sei se a gente vai ficando... ou amadurecendo mesmo; o quê que eu quero para essa vida, para esse profissional, que sensibilidade eu quero que ele tenha, como é que eu posso querer que ele seja um profissional dessa forma se eu não for assim com ele! Tentar mostrar também essa outra visão. Acho que seria mais assim... uma visão qualitativa, integral, acho que uma visão holística. A capacitação hoje, acho que ela tem ocorrido com a experiência também, acho que estou aberta para novos aprendizados, acho que prestando um pouco de atenção na prática da gente, porque só assim que a gente consegue melhorar, modificar. Eu acho que poderia ter uma capacitação hoje, uma troca maior, a gente não tem conseguido. Acho que como tivemos nos moldes anteriores, oficinas, os seminários que a universidade propunha e desenvolvia. Hoje a gente percebe assim, a gente caminha e às vezes volta e retoma em alguns temas e fala assim: pôxa isso eu já ouvi há 15 anos, não é novo... e a gente percebe assim, na enfermagem especialmente, a gente tem um grupo que tem uma história muito forte e que caminhou dessa forma. Então, às vezes a gente ouve sobre avaliação e todo mundo fica assim... alvoroçado e nós da enfermagem já tivemos, já discutimos avaliação há muito tempo, nós já tivemos um ganho, um crescimento e a gente percebe outros pares quando a gente tem esse eventos que parece que é tudo tão novo e a gente já vem fazendo isso. Então eu gostaria dessa capacitação hoje, mais essa troca esse, caminhar conjunto, até uma análise, eu enxergo assim, mas será que é dessa forma? Como é que a gente pode estar trocando.

\section{3-Como você pensa que deva ser a continuidade desta capacitação e quais competências julga que ainda deva desenvolver?}

A continuidade, acho que seria nessa linha mesmo, de... pôxa acho essa última pergunta mais difícil de responder porque que competências a gente acha que deve desenvolver, a gente só sabe o que deve desenvolver se a gente tiver consciência delas então acho que o que desenvolver já está tentando, não sei se tem alguma coisa assim... eu acho que é difícil essa competência, voltando à pergunta anterior, a gente já tem uma competência mais tecnológica, porque é um linguajar diferente, os jovens de hoje vem com outras exigências com outra experiência, de estar usando essa experiência deles no momento atual, o acesso à Internet, a informação tão rápida, qual que é a qualidade dessa informação?Como a gente pode usar isso, em benefício daquele conteúdo que a gente está ministrando, então, eu acho que teve essa competência que tem hoje e que não havia antigamente, do acompanhar essa tecnologia e o desafio é como a gente atrela tudo isso, lembrando que não é só a competência técnica, tem a crítica e como fazer isso. Nossa! Que difícil! Porque é o antes, o agora e o depois! Fica um emaranhado né? Porque você vai mudando e você não consegue mais saber como é que você era antes, fica diferente esse olhar porque parece que você já era assim né? E não era né? Acho que é isso.

\section{Entrevista E-07 \\ 1-Como ocorreu sua capacitação para ser docente de enfermagem e quais competências julga que desenvolveu?}

Na verdade a capacitação é um processo em construção, ninguém é docente de um dia para o outro, mesmo porque a gente se forma enfermeira e a enfermeira tem uma conotação essencial... mais técnica, 
mais voltada...pelo menos quando eu me formei, para a parte do cuidar. Quando a gente vai entrando em contato com o aluno, é um processo de construção, devagar, que não acaba nunca. Nós somos seres inacabados mesmos, então eu acredito que a gente sempre vai estar aprendendo. Então essa capacitação tem ocorrido no transcorrer dos meus anos. Claro que para ajudar essa capacitação, com certeza alguns cursos tem ajudado, que eu colocaria para você como aprimoramento e esse aprimoramento seria através de um curso de especialização que o de metodologia do ensino superior que foi ministrado pela universidade, para todos os docentes novos, em 79, dando algumas dicas de como deveríamos utilizar algumas estratégias em sala de aula, que era isso que nos deixava mais assustadas no início. Quando você começa, você pensa que sabe tudo e com o decorrer do tempo, você também pensa que não sabe nada, então por isso que é um processo. Então essas capacitações que tem tido de metodologia do ensino superior e o próprio mestrado, que já te dá uma bagagem para você entrar como educador, acho que isso têm sido momentos ímpares que contribuíram no meu crescimento como docente. Outra coisa que também considero importante que faz com que você se capacite, é o autoconhecimento e a autonomia intelectual; eu acredito que 0 aluno ajuda a construir o seu conhecimento também, esse é um vínculo que você estabelece e esse vínculo que faz com que você cresça ou fique estagnado. Essa transformação que o próprio aluno propicia, eu acho que é o processo educativo do enfermeiro, que não é que vai virar docente, mas ele continua sendo um professor em construção.

\section{2-Como você percebe que ocorre a sua capacitação hoje e quais competências julga estar desen- volvendo?}

Eu tenho dois momentos aqui, para comentar com você, o primeiro momento eu achava que eu era uma professora assim... o máximo. O máximo porque eu conseguia dar todos os meus conteúdos, achava que sabia tudo e eu me achava o máximo mesmo, sempre achei que tinha uma bagagem muito boa, eu gosto de estudar, de ir a congressos... só que depois você tem uma queda, você começa a olhar e percebe que não sabe nada, ao contrário você também é um indivíduo em construção e aí você começa a perceber que a sua capacitação hoje é contínua. Se você não tiver uma capacitação continuamente, você para no espaço. Então aquele conteúdo que eu achava maravilhoso, tudo sobre fisiopatologia, o que você me perguntasse eu sabia, mas eu vejo que não é nada comparada com o vínculo que você faz com o aluno no ensino/aprendizagem. Porque é esse cuidar, é esse vínculo que transforma 0 enfermeiro não em docente, mas que dá brechas, alguns focos para ele começar a construir a sua identidade como docente. Acho interessante esses dois momentos como eu coloco, porque agora eu percebo que não sou tão petulante e antes sim me achava o máximo e isso era muito confirmado esse máximo através de títulos, de ser paraninfa, etc, ficava mais ainda...a minha vaidade ia lá para o céu. Agora não, acho que estou em um momento de humildade e de achar que estou ainda neste processo de ensino/aprendizagem. É claro que nós não somos páginas em branco, então com certeza alguma coisa a gente consegue passar, de experiência até de vida. Então a capacitação ocorreu.

\section{3-Como você pensa que deva ser a continuidade desta capacitação e quais competências julga que ainda deva desenvolver?}

Bom, acho que esta pergunta venho respondendo ao longo do meu discurso, mas a capacitação ela vem sempre e sempre vai se processar com o outro. Não é uma coisa solitária, eu acho que essa capacitação é uma autonomia tua, mas sempre vinculada a um grupo, uma coletividade, ao aluno, ao grupo de docentes, a própria ideologia que você tem, de pensar que você quer realmente que se processe uma capacitação de ensino/aprendizagem que você queira realmente uma coisa melhor para 0 aluno. Eu acho que a Educação passa por isso, o processo educacional passa por isso é um processo de transformação mesmo. $O$ que eu queria mesmo, que é assim... o que a gente almeja, quando se fala em continuidade, é ter essa autonomia intelectual não para dizer que aquela pessoa sabe tudo, mas para dar alguns lampejos de luz e pra gente construir em conjunto. Eu acredito muito que a construção de alguma coisa, até da capacitação deva ser interdisciplinarmente e se você não tiver essa coisa interdisciplinar, eu, sozinha com meu conteúdo de pediatria, não vou conseguir construir muita coisa nem me capacitar muito quem sabe com o seu conteúdo, com o conteúdo da outra professora, a gente vai juntando formando um ser humano um pouquinho melhor. 


\section{Entrevista E-08 \\ 1-Como ocorreu a sua capacitação para ser docente de enfermagem e quais competências julga que já desenvolveu?}

Bem, você me faz voltar ao início da década de 1980, quando eu ingressei na Universidade. Na verdade, o primeiro ano que eu trabalhei na PUCC, foi como enfermeira do hospital; então eu não tinha vínculo com o ensino, embora o contrato fosse vinculado à escola; então eu comecei mesmo o meu trabalho como docente em 1981 há 24 anos atrás. É um pouco assustador esse tempo, e eu diria que a minha inserção na área do ensino, não foi uma opção naquele momento, acho que foi decorrência da minha presença aqui no hospital e maternidade Celso Pierro, no trabalho como enfermeira dos ambulatórios e por esse vínculo que existia da Escola com o Serviço; então naquele momento...eu tenho que te fazer uma correção: contrato de escola, trabalho de escola e não trabalho na Instituição hospitalar ou no ambulatório. Então eu acabei sendo chamada para desenvolver o trabalho mesmo, com os alunos. Acho importante fazer essa retomada para eu me rever nessa trajetória de ensino de 24 anos. Eu comecei na escola sem nenhuma formação pedagógica específica e acho que era fruto até da época, as pessoas tinham que ter um domínio técnico, um conhecimento científico, era isso que era valorizado para o trabalho do enfermeiro e eu poderia te dizer, até da docência na área; era você ter conhecimento específico daquela área que você ia atuar, porque a idéia era passar o conhecimento, transmitir aquilo que você sabia. Então acho que isso era um predomínio da própria pedagogia da década de 70,80 . Na seqüência a gente mesmo vai percebendo a necessidade de se capacitar, de se preparar, tanto na área específica, como trabalhar as questões da Educação e... na Faculdade de Enfermagem, nós tivemos uma trajetória muito interessante, que foi assim...acho que tem que retomar o nome da professora Mara que ficou à frente da direção por 8 anos consecutivos e nessa época, coincidiu também com uma época muito fértil na Universidade, em que se trabalhou muito a temática da Educação, dos temas da Educação, do que é ser um professor, do que é uma educação transformadora, então, embora não existisse uma formação formal porque nós não éramos pedagogos, educadores na formação básica, mas nós tivemos a oportunidade de fazer essa discussão, a Universidade, a escola trazia uma série de palestristas, pessoas de renome Terezinha Rios, Paulo Freire, então a gente teve contato com pessoas de expressão no cenário nacional e até internacional na área de Educação. Isso contribuiu muito, isso foi dando um embasamento da área da Educação que a gente não tinha. Acho que até por essa razão acabei buscando a capacitação de mestrado na área de Educação. Acho que essa vivência que permitiu mesmo conhecer um pouco mais das várias pedagogias, eu acho que o professor em que pese toda a necessidade de domínio da área específica dele, de atuação, ele precisa ter alguma formação na área de educação; não é uma coisa que é mágica; você deixa de ser profissional para ingressar no mundo da docência. Acho que tem que ter um preparo, uma discussão, é preciso que você conheça as propostas pedagógicas do seu curso, da instituição onde você está vinculado, projeto político pedagógico da instituição e entenda um pouco da Educação, das várias modalidades, das várias possibilidades de ensinar, de avaliar, que é uma temática bem polêmica, complexa a questão da avaliação, então, eu acho que precisa ter esse domínio.

\section{2-Como você percebe que ocorre a sua capacitação hoje e quais competências julga estar desen- volvendo?}

A minha capacitação nos dias de hoje, acho que até dando continuidade na capacitação, na formação acadêmica né? Que foi o mestrado na área de educação; eu acabei fazendo a trajetória específica da minha área que era o doutorado na área da saúde coletiva e eu senti que me distanciei um pouco dela enquanto espaço mais formal, assim, de estudos, de aprofundamento, porque eu fiquei por um tempo ligada na área de educação, também comecei a assumir disciplina que era bem da educação, que era a didática na área da enfermagem ou ações educativas para o enfermeiro, então, isso me fez reaproximar muito disso, a retomada do doutorado na saúde coletiva, acho que para buscar mesmo um período de afastamento de um ... de uma formação mais acadêmica da área e o que eu procuro fazer hoje para trabalhar e para me desenvolver enquanto docente, é me inserir nos grupos de discussão que a universidade promove, participar de palestras da área, cursos de capacitação que a universidade hoje está oferecendo né? A formação permanente do professor, fazer algumas leituras da área, então eu acho que é mais nesse sentido. Agora, tudo isso, apesar de ter essa preocupação, tem uma outra questão que me preocupa, que é a forma como o jovem chega na universidade e como hoje a sociedade está valorizando o jovem com acesso ao mundo da informática, eu vejo que a gente compete um pouco a atenção dele, aquelas aulas por mais que você queira avançar e tudo mais, a competição com o mundo da Internet, as informações, a 
questão da agilidade de conhecimento e tudo, é difícil. Eu vejo pelos meus filhos, o que atrai mais? são quatro horas sentado num banco escolar ou quatro horas na frente da Internet navegando acessando uma série de sites, se comunicando com o mundo. Então, eu acho que é um desafio que está colocado para o professor hoje e para as escolas né? Como é que a gente consegue acompanhar isso, mas mantendo o nosso ensino, os conteúdos que tem que ser trabalhados e induzidos, mantendo a preocupação com a produção do conhecimentos para esse aluno, que pode ser de repente por Internet uma série de trabalhos que pode ser um corta e cola né? Prontinho, sem ter feito uma leitura, uma crítica, então...são riscos do mundo atual que a gente tem que enfrentar.

\section{3-Como você pensa que deva ser a continuação desta capacitação e quais competências julga que ainda deva desenvolver?}

Eu sou defensora daquela idéia de que a gente tem que estar a vida inteira aprendendo. Aprendendo profissionalmente, pessoalmente... eu acho que o meu aprimoramento agora, uma área que eu precisaria me dedicar mais, seria a área da pesquisa. Eu acho que isso poderia inclusive, qualificar meu trabalho, permitir a inserção de mais alunos no projeto de pesquisa, no projeto de iniciação científica dentro da escola, então a gente é um pouco tímida ainda nisso, a gente tem poucos professores em carreira, poucos professores fazendo pesquisa e eu ao longo desses anos, envolvida com cargo administrativo e com o próprio doutorado, quer dizer, fiz a minha pesquisa e minha investigação por causa do doutorado, mas agora eu sinto que tenho esse compromisso com a continuidade de investigação científica, eu vejo que preciso também trabalhar a questão de publicação, eu acho que é uma área que é muito frágil, na minha vivência, na minha trajetória profissional e que eu preciso investir nisso. Acho que isso é bom para mim, para a escola e tudo mais. Pensando na questão da publicação, acho que é da gente começar a documentar, a gente ter preocupação com o registro com o trabalho que a gente faz muitas vezes. A gente passou, evoluiu bastante, mas a gente ainda trabalha bastante e registra pouco o que faz. Agora, eu fico pensando nas competências para ser professor, acho que a gente tem que estar atualizada, tem que estar antenada com tudo que está acontecendo no mundo, tem que estar informado sobre tudo que está acontecendo na profissão, nós temos esse compromisso de situar o aluno na profissão que ele abraçou, que ele escolheu, situar essa profissão na sociedade, contextualizar na sociedade em que a gente vive, num mundo contemporâneo, então é um papel assim de muita responsabilidade que a gente tem e para isso valer, tem que discutir com os pares, se posicionar, fazer a crítica do momento atual, daquilo que está ocorrendo, isso dá um diferencial importante para uma educação que você não pretende que seja só uma repetição, uma transmissão do conhecimento; que seja mesmo numa linha de promover uma autonomia intelectual para 0 aluno, de contribuir para que 0 aluno seja realmente produtor de seus conhecimentos e seja alguém que vai fazer a transformação dessa sociedade, alguém que vai fazer a diferença, inserido naquele trabalho, naquela comunidade, acho isso fundamental.

\section{Entrevista E-09 \\ 1-Como ocorreu sua capacitação para ser docente de enfermagem e quais competências julga que desenvolveu?}

Não existe uma capacitação propriamente dita, antes de eu concluir a graduação fui trabalhar em uma área que não é de interesse de muitas pessoas, e desde daquele período eu já tenho interesse pela psiquiatria.

Por haver sido convidada pela diretora para trabalhar, para compor o quadro de docente durante a graduação nós tivemos sorte em fazer a licenciatura, no que era possível naquele momento, e logo que eu conclui eu fui fazer a residência em Ribeirão Preto dentro da área especifica daí que eu comecei a dar aula. Então a minha capacitação para a docência foi essa, mas não tinha nada de especifica, não existiu capacitação efetivamente. Acho que poderia falar de muitas coisas, até que eu já tivesse uma uniformidade aí, de compreensão do que seria competência, mas pegando coisas simples, eu consideraria...olha, conseguir estar na frente de uma classe e estar tranqüila com isso e isso não ser uma coisa que te atemoriza, é uma competência e ela é boa é imprescindível para o início do seu fazer, agora, competência que já desenvolvi, acho que assim, de uma visão educacional diferente, que ela me é funcional. 


\section{2- Como você percebe que ocorre a sua capacitação hoje e quais competências julga estar de- senvolvendo?}

Nesse transcorrer eu acho que eu fui fazendo uma capacitação mais específica de transformação dentro da área e concomitante, eu só não tive sorte eu acho que há muitos anos atrás a Pucc investiu muito nisso. Depois nós fizemos todos os cursos que posteriormente eles foram ministrados, com pessoas que eram referência na área da educação, tudo investindo na capacitação, naquele momento eu não sei se a gente queria muito ou era obrigado, enfim a gente fazia todos os que apareciam inclusive nos sábados. Eu sei que estes cursos contribuíram muito para atividade docente, nós fomos trabalhando eu fui trabaIhando, fui ganhando experiência, amadurecimento também, aliada a formações que a gente vai tendo, vai dando uma aprimorada neste fazer. Depois ainda eu fui fazer mestrado em educação e que foi uma escolha bem intencional; naquele momento eu não queria fazer na mesma área de atuação que achava que já tinha experiência e que o meu fazer era de docente eu precisava de mestrado na área de educação, sabe foi aquela coisa que eu quis muito e pesquisei, não foi por facilidade ou de localização, fui buscar na área de educação porque eu quis e acho que foi fundamental porque daí a gente vai entrando em contato com um conhecimento específico enquanto docente e foi possível amarrar o que a gente tinha de bom, aliar novos aspectos no nosso fazer e... me lembro com muito carinho por essa vivencia do mestrado, achei que foi muito bom em termos de formação para o que é uma profissão de ser educador, quer dizer, tenho uma formação básica em enfermagem, mas a minha profissão, eu sou docente eternamente trabalhei assim. Acho que tem uma leitura hoje do processo educacional muito diferente, muito mais amplo do papel do professor, do que se espera do aluno. Acho que essas competências por mais que a gente ache que já adquiriu, muitas delas a gente tem essa habilidade para usar com grupos menores, em campos de estágio, em pequenos grupos; daí você é o professor com mais competências, da leitura do que 0 aluno diz, da solicitação do papel que você espera dele como um elemento mais ativo na construção do conhecimento, então, se eu fosse me ver em termos de competências, eu vejo assim, dividido: 0 professor do pequeno grupo e o professor da sala de aula. 0 professor da sala de aula, por mais eu sei 0 que seria bom para ele, não me sinto competente para desenvolver bem isso. Me sinto perdendo do que eu sei que consigo fazer num pequeno grupo, que é ter objetivos, que eu acho que são concernentes a uma leitura do papel do educador hoje e que consigo fazer bem isso, no campo de estágio, num grupo de 10, 15 alunos ou até 20 , mas, com 80 eu não tenho esta competência.

\section{3-Como você pensa que deva ser a continuidade desta capacitação e quais competências julga que ainda deva desenvolver?}

Capacitação é a tal da coisa inconstante...não só para docente, para área especifica, enfim estamos num mundo em movimento e movimento rápido, então acho que as pessoas aprendem a ser desse jeito, vivem fazendo buscas, hoje quer dizer, sou uma pesquisadora eu tenho que fazer pesquisa, hoje quase na terceira idade (risos) eu acho como já te falei, a maturidade te dá uma condição de buscar outra ordem, outro tipo de literatura, então, eu acho que agente está em continua capacitação dada às transformações a gente tem de vivenciar coisas novas, um jeito novo de ser e quando se dá conta, surpreendentemente, vagarosamente, você mudou, cresceu; mas a gente tem que continuar, então, eu acho que é continuo não tem muito que pensar a idéia da capacitação para qualquer atividade, então, é para sempre essa capacitação. 0 que eu precisaria desenvolver talvez, seria mesmo competência para lidar com grandes grupos que eu ainda não sei e é por muito tempo, que eu aprendo coisas teóricas, cursos, leituras e acho que elas não me dão essa proteção, não é esse conhecimento que me dá essa habilidade. 
ANEXO 8

TRATAMENTO DAS FALAS DAS ENTREVISTAS - 1 
CATEGORIA - A TEMPORALIDADE NA CAPACITAÇÃO DOCENTE: O PASSADO

SUB-CATEGORIA - A TRAJETÓRIA PROFISSIONAL

\begin{tabular}{|c|c|c|}
\hline $\begin{array}{l}\text { ENTRE- } \\
\text { VISTA }\end{array}$ & UNIDADES DE SIGNIFICADO & PONTOS RELEVANTES \\
\hline E-01 & $\begin{array}{l}\text { 1.1.01 - Não houve uma capacitação formal. } \\
\text { 1.1.02 - Eu acho que vamos experimentando durante a nossa formação algumas aproximações com o ensinar e aprender. } \\
\text { 1.1.03 - Com transmissão de conhecimento por mais conservadora que seja a formação da Enfermagem, ela propicia essa capacitação. } \\
\text { 1.1.04 - Nunca fui uma aluna que foi monitora e nunca tive iniciação científica } \\
\text { 1.1.05 - Como aluna, eu tive em alguns estágios a possibilidade de trabalhar com temas de educação e saúde, principalmente na área da } \\
\text { saúde coletiva que sempre foi o meu eixo maior, o meu interesse maior durante a formação, então trabalho voluntário em comunidade, } \\
\text { em escola porque eu gostava de estar junto da população carente e mais os estágios que também ajudavam, então não houve uma ca- } \\
\text { pacitação formal houve essa aproximação dessa forma, muito incipiente, mas muito significativa. } \\
\text { 1.1.06 - Agora que você está me perguntando ela foi muito significativa, essa forma de trabalhar com o conhecimento a partir, ou por meio } \\
\text { dessas experiências com educação e saúde. } \\
\text { 1.1.09 - Eu considero que as competências desenvolvidas foram: a comunicação, a percepção de algumas variáveis que fazem parte do } \\
\text { processo de ensinar e aprender tais como histórias de vida, exemplos vividos profissionalmente, situações vivenciadas em estágios com } \\
\text { alunos e levadas para a sala de aula para outros alunos, compartilhamento de emoções, lições de vida, alteração dos julgamentos pré- } \\
\text { estabelecidos e que diante de uma situação que você jurava que agiria de tal forma, você se depara agindo de outra e isso é bom, pode } \\
\text { se rever, alterar coisas e modos de pensar. }\end{array}$ & $\begin{array}{l}\checkmark \text { Não havia capacitação formal } \\
\checkmark \text { Experiências vivenciadas durante a } \\
\text { graduação } \\
\checkmark \text { Experiências vivenciadas no cotidiano } \\
\text { profissional } \\
\checkmark \text { Capacitação desenvolvida: educação } \\
\text { em saúde, percepção de variáveis do } \\
\text { processo de ensinar e aprender; lições } \\
\text { de vida, vivências profissionais, com- } \\
\text { partilhamento de emoções, alteração } \\
\text { de julgamentos; comunicação, atenção } \\
\text { à saúde, relacionamento interpessoal. } \\
\checkmark \text { Aspectos facilitadores para a docência: } \\
\text { vivência, monitoria, iniciação científica, } \\
\text { estágios. }\end{array}$ \\
\hline $\mathrm{E}-02$ & $\begin{array}{l}\text { 2.1.02 -. Quando eu estava no colegial e no ginásio, eu trabalhava como docente, não de enfermagem, mas dando aula particular para } \\
\text { vestibulinho, curso de admissão e para entrar no colegial. } \\
\text { 2.1.04 - Eu não tive capacitação pedagógica, porque eu não fiz licenciatura. } \\
\text { 2.1.05 - Eu entrei aqui e eu nem sabia fazer um planejamento didático. Eu aprendi aprendendo. } \\
\text { 2.1.10 - Foi de uma maneira completamente empírica que eu aprendi a ser professora. } \\
\text { 2.1.13 - Na modalidade de estágio, eu tinha um maior preparo, você tem que estudar mais, as dificuldades que se apresentam essa rela- } \\
\text { ção professor/aluno no cotidiano, ela envolve algumas coisas que você deve aprender, mas eu tinha mais facilidade, talvez alguma difi- } \\
\text { culdade na hora de fazer avaliação, de eleger critérios subjetivos. }\end{array}$ & $\begin{array}{l}\checkmark \text { Não havia capacitação formal } \\
\checkmark \text { Experiências vivenciadas no cotidiano } \\
\text { profissional } \\
\checkmark \text { Experiências vivenciadas ministrando } \\
\text { aulas particulares } \\
\checkmark \text { Capacitação desenvolvida: planeja- } \\
\text { mento, preparo profissional, avaliação. } \\
\checkmark \text { Aspectos facilitadores para a docência: } \\
\text { preparo profissional para a prática } \\
\checkmark \text { Aspectos dificultadores para a docên- } \\
\text { cia: não saber fazer planejamento, difi- } \\
\text { culdade em eleger critérios subjetivos } \\
\text { para avaliação. }\end{array}$ \\
\hline
\end{tabular}


E-03 $\quad$ 3.1.01 - Eu certamente preciso fazer quase que uma revisão histórica mesmo, quer dizer, como que eu chego na enfermagem, como eu consigo pegar talvez um primeiro contato com essa idéia de docente e que certamente tem muito a ver com o estar hoje na docência.

3.1.02 - Eu fiz o técnico de enfermagem.

3.1.06 - Eu fui fazer o técnico porque à época, no país tinha um incentivo a fazer o curso técnico, como está hoje novamente, até por conta da falta de...certeza de que você ia fazer um curso de graduação e por eu não ter esta certeza, optei por fazer um curso técnico. Eu queria colocar então aí, acho que um marco dessa trajetória.

3.1.13 - Então quando vinha grupo novo de internos, um grupo novo de residentes, a gente tinha esse papel de passar todas as questões, fazer as trocas, delinear e eles chamavam com muita tranqüilidade todo o tempo foi um processo de compartilhamento, que dizer do que eu sabia até então e a isso eu atribuo que era toda uma forma, não que eu estivesse já com uma idéia de que eu iria vir para uma área de ensino, mas certamente estava muito embutido, muito inserido em mim porque eu tinha esse processo com muita tranqüilidade, talvez como se eu estivesse me preparando.

3.1.14 - Eu acabei trabalhando nessa área na unidade de internação e na seqüência fui trabalhar na comissão de controle de infecção hospitalar e aí abriu um leque enorme, porque vi me relacionando com vários outros profissionais que eu não tinha um contato mais próximo, como o serviço de higiene, o serviço de lavanderia, com o serviço de laboratório; o que acabou acontecendo, isso ampliou muito a minha visão e os meus contatos e o foco era o papel educativo, na comissão do controle de infecção.

3.1.15 - Eu estava fazendo paralelamente o curso de administração hospitalar, que previa que a gente tivesse contato com todos os serviços então, ampliou mais ainda, pois eu fui até para o serviço de prontuário de paciente, fui fazer contato com o serviço social enfim, era como se eu conseguisse visualizar aquela estrutura de uma outra forma e conseguisse atuar muito nesta questão educativa.

3.1.16 - Depois eu fui propor um processo de integração com a faculdade de enfermagem, eu e uma professora montamos a proposta para o setor de educação continuada que ainda não tinha. Esse foi um processo mesmo de seleção que houve no hospital e eu passei. Então o meu vínculo com a escola sempre foi muito grande. E com esse projeto de educação continuada e eu vou cada vez mais me aproximando desse processo de ensino/aprendizagem.

3.1.17 - Eu fui então convidada a trabalhar no gerenciamento do serviço de enfermagem, a escola tinha essa proposta de integração, colocou alguém junto, uma docente para poder assessorar diretamente e para poder desenvolver esse processo comigo e me preparar para isso; me vejo envolvida em reuniões com a escola, para poder discutir também como que o serviço contribuiria com a formação, enfim, continuo envolvida com as questões do ensino por traz disso.

3.1.18 - Depois de dois anos surge uma oportunidade na escola, na área de administração de enfermagem, havia uma exigência que tivéssemos e eu já tinha uma especialização, mas o ideal seria que eu estivesse inserida em um curso de pós-graduação ou de mestrado.

3.1.19 - Estava começando um curso de mestrado em educação e entendi que teria que fazer em educação, pensei como eu vou para área de docência, eu tinha licenciatura que fiz durante a faculdade, mas era insuficiente, fui fazer minha inscrição, ao mesmo tempo que eu estava sendo selecionada aqui pra escola eu estava sendo selecionada no curso de mestrado, eu entendi que ele iria me ajudar muito, como me ajudou, ampliou muito minha visão, de ver um contexto porque a área de concentração é de ensino superior (...) para trabaIhar com planejamento em educação, porque até então eu sabia trabalhar planejamento em serviço, não para educação, então foi muito rico, sinto que foi um momento importante para a minha capacitação, porque agora sim eu iria me formar docente de um curso de graduação, então passei pela seleção acabei sendo aprovada nos dois porque a escola entendeu que eu já estava na verdade buscando. $\checkmark$ Capacitação formal na graduação e após inserção a na docência

$\checkmark$ Experiências vivenciadas na academia

$\checkmark$ Experiências vivenciadas no cotidiano profissional

$\checkmark$ Capacitação desenvolvida: ampliação de visão, planejamento em educação, atividades técnico-científicas, assistenciais, gerenciais e educativas.

$\checkmark$ Aspectos facilitadores para a docência: experiência de monitoria, trabalho em hospital escola, capacitação formal na área da educação, oportunidades de trocas, informações, compartilhamento com grupos de alunos, experiência assistencial para um possivel futuro profissional na área da docência, relacionamento multiprofissional, vivenciou 0 papel educativo do enfermeiro em comissão de controle de infecção hospitalar, ampliação de visão nos contatos com outros Serviços do hospital, relação do curso de administração hospitalar com o cotidiano profissional, integração com o ensino quando fez uma proposta de um setor de educação continuada, experiência de vínculo com a escola, assessoria da escola no gerenciamento do serviço. 
3.1.20 - Quando eu fui prestar o doutorado, a banca fez uma análise do meu currículo olhando para isso, desde o técnico eu já participava de todos os eventos que eu podia e durante a faculdade, depois que eu fui para o serviço, era um contínuo não havia quebras e lógico que voltado a cada momento do que eu estava fazendo eu ia me capacitar naquilo que estava trabalhando mais de perto, me lembro que foi feita uma análise e é interessante que você mesma nem percebe, porque se torna tão cotidiano você procurar essas coisas.

3.1.21 - A minha capacitação para docente de enfermagem, quando chego para a docência ela tem esse marco no técnico essa continuidade na faculdade, uma vida profissional em um hospital universitário que me exigia esse tipo de coisa, e que para mim era uma exigência prazerosa, pois eu tinha prazer em fazer isso, então o marco mesmo da capacitação no mestrado na área de educação especificamente reconheço que me capacitei muito para isso.

3.1.22 - Na continuidade eu fui depois fazer o doutorado eu tinha um desejo de voltar para a área da enfermagem, hoje acho que é importante não me arrependo e que devia ter voltado mesmo, achei que foi importante porque comecei ver vinculada essa questão do ensino dentro da área que eu escolhi, que eu gosto e tenho certeza era o que eu tinha que fazer.

3.1.23 - Fiz meu doutorado, tudo isso me capacitando, eu me torno docente de enfermagem, o doutorado vem já enquanto docente, na seqüência, embora o mestrado paralelo também.

3.1.24 - Naquele momento desenvolvi competências técnico-científicas relativas à área de enfermagem em aspectos não só assistenciais, mas gerenciais e educativos, sendo que estes últimos certamente promoveram a condição para na seqüência, desenvolver junto à equipe de enfermagem questões educativas, bem como a presença de alunos de graduação da área da saúde também estimularam o colocar em prática este aspecto educacional.

4.1.01 - A capacitação docente ocorreu posteriormente, quando eu já era docente.

4.1.5-eu acho que desenvolvi a competência da interação aluno/professor, a competência do uso de novas estratégias para levar o aluno a uma reflexão holística do paciente no que diz respeito não só da parte biológica, mas também a parte social e política, acho que consegui a competência de estimular o aluno à produção do saber, desenvolvi a competência da pesquisa e da observação.

4.3.15 - o que eu sinto é o seguinte: no início da profissão, quando comecei, estava muito estimulada, eu fiz habilitação em médicocirúgica, especialização em enfermagem do trabalho, terminei e fiz administração hospitalar, depois vieram esses cursos aqui, que estavam oferecendo, com o passar do tempo houve uma acalmia, a gente deixa acalmar os ânimos.

4.3.16 - só depois que comecei o curso de mestrado em educação, que fui me sentir motivada novamente.

5.1.01 - eu percebo dois momentos bem distintos um do outro, quando comecei a me ver como docente.

5.1.06 - eu não tinha um saber que me sustentava.

5.1.08 - Isso era o meu patamar, era como eu me via fazendo e foi assim que eu me fiz docente, praticamente repetindo esses modelos, procurando um conhecimento bastante grande da área, que eu queria colocar, era bastante fechada na enfermagem mesmo, e a busca de uma clareza da exposição dos conceitos, de exemplificação, etc.

5.1.11 - eu comecei, tanto no mestrado e depois no doutorado, a buscar uma interface entre as questões do ensino da enfermagem e a alguns aspectos polêmicos da prática pedagógica, buscar entender, aprofundar. $\checkmark$ Capacitação formal após inserção na docência

$\checkmark$ Experiências no cotidiano profissional

$\checkmark$ Capacitação desenvolvida: interação professor/aluno, uso de novas estratégias para reflexão, estímulo para produção do saber, pesquisa e observação.

$\checkmark$ Aspectos facilitadores para a docência: estímulo para a docência, capacitação em área afim.

$\checkmark$ Capacitação formal após inserção na docência;

$\checkmark$ Experiências no cotidiano profissional

$\checkmark$ Capacitação desenvolvida: conhecimento, ampliação de visão, entendimento da relação entre área específica e ensino. 
5.1.12 - Fiz isso no mestrado, na própria enfermagem; foi um caminho interessante, mas insuficiente.

5.1.14 - no começo da minha prática pedagógica, eu era tida como uma boa professora pelos alunos, dentro do perfil considerado competente, técnico, e aí, era curioso, porque é uma coisa que eu não entendia de onde vinha, porque eu tinha um reforço positivo dos alunos, eles gostavam do jeito que eu dava aula.

5.1.15 - à medida que eu fui começando a estudar e a entender isso, eu comecei a perceber que um monte de coisa que nos livros não traziam, nos livros de enfermagem, ou mesmo algumas práticas que eu reproduzia, tinha uma dimensão do humano, das relações que permitiam que eu pudesse me comunicar melhor e comunicar melhor os conteúdos que à época eu queria estar trabalhando.

5.1.16 - Interessante como muda essa concepção do que seria um bom docente, por um primeiro enfoque, quando eu percebo que aquele modelo que eles celebravam, na realidade ele era limitante e é como se eu fizesse muito mal aos alunos, na medida em que eu estreitava a possibilidade deles verem além.

5.1.17 - eu começo a arriscar apoiada nesses outros referenciais, na outra prática de docência em enfermagem, que não é tão exitosa, na medida em que ela não é reconhecida pelos alunos, como aula.

5.1.18 - eu gostava de ver cada vez mais a docente em que estava me transformando e, eu era cada vez menos popular. Era um trabalho muito assim...sofrido porque...parecia que o tempo não tinha sincronia, meu tempo e no tempo deles e isso é quase que um convite a voltar para a prática antiga, mas que resvala na sua outra forma de entender o teu papel.

5.1.20 - A gente vai descobrindo na medida em que começa a prestar atenção, atenção primeiro nas pessoas e o retorno imediato que elas me davam e depois comecei a pensar num retorno a médio e longo prazo e aí eu comecei a entender que não é só o aqui e agora, aquela festa, aquela vitória de momento; eu queria outras coisas, passou a ser um desafio.

5.3.37 - Como eu fiquei mais hoje professora universitária do que enfermeira, passou a ser um instrumento de trabalho a reflexão sobre essa prática pedagógica, que eu produzo, enquanto aprendo.

5.2.29 - eu tive momentos de práticas que eu amei profundamente ter feito e o retorno não foi bom e quando eu voltei no semestre seguinte já não estava tão entusiasmada em tornar a aplicá-los. Sabe quando você pensa o tempo inteiro: o que é certo o que é errado, para onde que eu vou?

E-06 6.1 .01 - a capacitação foi ocorrendo com a própria trajetória profissional, acho que é difícil separar as duas coisas.

6.1.02 - não me formei para ser professora, na verdade aconteceu, eu não tive uma formação na época, a gente tinha licenciatura, mas eu não fiz.

6.1.03 - fiz a graduação e fui fazer residência em enfermagem

6.1.05 - Sempre o que me guiou foi realmente a parte do cuidado, então eu fui buscar a competência para esta prática.

6.1.06 - enfoque educacional foi surgindo durante a residência, você acaba tendo que fazer trabalho, aula e socializar todo esse conteúdo, então foi uma coisa que começou a surgir naturalmente.

6.1.07 - na residência tinha um enfoque para educação continuada do hospital e comecei a me identificar muito com o ensino, nessa fase com o ensino de funcionário.

6.1.11 - Comecei com o estágio, depois aos poucos fui assumindo a teoria e fui gostando muito.
Aspectos facilitadores para a docência: capacitação formal, estudo, percepção da dimensão humana, capacitação técnica, dimensão do humano na prática docente, mudança de concepção do ser bom docente, desafio para mudanças, reflexão sobre prática pedagógica.

$\checkmark$ Aspectos dificultadores: formação tecnicista; falta de conteúdos pedagógicos.

$\checkmark$ Não havia capacitação formal

$\checkmark$ Experiências no cotidiano profissional

$\checkmark$ Experiências em pós-graduação na modalidade residência em enfermagem

$\checkmark$ Capacitação desenvolvida: supervisão de estágio e ministrar aulas teóricas, cuidado, política, ética

$\checkmark$ Aspectos facilitadores para a docência: elaboração de trabalhos, aulas e socialização do conteúdo em pós- 
6.1.12 - não tive uma capacitação formal ela foi se dando pela prática mesmo, com a vivência.

6.1.16 - as competências que desenvolvi, acho que teve a competência técnica, acho que fui desenvolvendo bastante a competência política mesmo, do aluno, trabalhando com aluno, é a função educativa do enfermeiro, com o paciente de como a gente pode fazer essa interface, acho que isso aconteceu e lógico está junto toda a competência ética, a gente vai tentando.

6.2.17 - Eu acho que saí de uma competência, não sei se posso chamar assim, mas uma competência positivista, do próprio sistema de avaliação, isso está errado, vai recuperar, mas o que é essa recuperação, exame.

6.2.19 - eu vim com uma competência no início e acho que a gente foi aprendendo, foi crescendo e foi vendo essa condição um pouco mais humanista, de tentar entender o aluno, de compreender esse nosso aluno trabalhador, de ver onde a gente pode motivar, ao invés de cobrar.

E-07 7.1.01 - capacitação é um processo em construção, ninguém é docente de um dia para o outro, a gente se forma enfermeira e a enfermeira tem uma conotação essencial, mais técnica, mais voltada para a parte do cuidar.

7.1.02 - Quando a gente vai entrando em contato com o aluno, é um processo de construção, devagar, que não acaba nunca.

7.1.03 - Nós somos seres inacabados, então eu acredito que a gente sempre vai estar aprendendo. Então essa capacitação tem ocorrido no transcorrer dos meus anos.

7.2.11 - você é um indivíduo em construção e aí começa a perceber que a sua capacitação hoje é contínua. Se não tiver uma capacitação continuamente, você para no espaço.

7.3.17 - o processo educacional é um processo de transformação que a gente almeja, quando se fala em continuidade, é ter essa autonomia intelectual para dar alguns lampejos de luz e para gente construir em conjunto.

7.1.05 - Quando você começa, você pensa que sabe tudo e com o decorrer do tempo, você também pensa que não sabe nada, então por isso que é um processo.

7.1.06 - essas capacitações que têm sido de metodologia do ensino superior e o próprio mestrado, que te dá uma bagagem para entrar como educador, isso têm sido momentos ímpares que contribuíram no meu crescimento como docente.

7.1.09 - Essa transformação que o próprio aluno propicia, eu acho que é o processo educativo do enfermeiro, que não é que vai virar docente, mas ele continua sendo um professor em construção.

7.2.10 - Eu tenho dois momentos aqui, para comentar com você, o primeiro momento eu achava que eu era uma professora assim... 0 máximo, porque eu conseguia dar todos os meus conteúdos, achava que sabia tudo e eu me achava o máximo; sempre achei que tinha uma bagagem muito boa, eu gosto de estudar, de ir a congressos, só que depois você tem uma queda, você começa a olhar e percebe que não sabe

7.2.12 - aquele conteúdo que eu achava maravilhoso, tudo sobre fisiopatologia, o que você me perguntasse eu sabia, mas eu vejo que não é nada comparada com o vínculo que você faz com o aluno no ensino/aprendizagem. Porque é esse cuidar, é esse vínculo que transforma o enfermeiro não em docente, mas que dá brechas, alguns focos para ele começar a construir a sua identidade como docente.

7.2.15 - nós não somos páginas em branco, com certeza alguma coisa a gente consegue passar, de experiência até de vida. Então a capacitação ocorreu. graduação na modalidade residência em enfermagem, vivências na educação continuada de funcionários, entendimento do aluno, compreensão sobre aluno trabalhador, transformação da docência "positivista"

$\checkmark$ Capacitação formal após inserção na docência.

$\checkmark$ Experiências no cotidiano profissional

$\checkmark$ Capacitação desenvolvida: metodologia de ensino, conhecimento, interação professor/aluno, autonomia intelectual

$\checkmark$ Aspectos facilitadores para a docência: capacitação formal em metodologia do ensino superior e doutorado, participação em eventos científicos; transformação propiciada pelo aluno, gostar de estudar, experiência de vida. 
8.1.02 - a minha inserção na área do ensino não foi uma opção, acho que foi decorrência da minha presença aqui no hospital, no trabalho como enfermeira dos ambulatórios e por esse vínculo que existia da Escola com o Serviço; eu acabei sendo chamada para desenvolver o trabalho mesmo, com os alunos.

8.2.12 - comecei a assumir disciplina que era bem da educação, que era a didática na área da enfermagem ou ações educativas para o enfermeiro.

8.1.03 - Acho importante fazer essa retomada para eu me rever nessa trajetória de ensino de 24 anos.

8.1.04 - Eu comecei na escola sem nenhuma formação pedagógica específica e acho que era fruto da época, as pessoas tinham que ter um domínio técnico, um conhecimento científico, isso que era valorizado para o trabalho do enfermeiro e eu poderia te dizer, até da docência na área; era você ter conhecimento específico daquela área que você ia atuar, porque a idéia era passar o conhecimento, transmitir aquilo que você sabia. Então acho que isso era um predomínio da própria pedagogia da década de 70, 80.

8.1.08 - Acho que até por essa razão acabei buscando a capacitação de mestrado na área de Educação, eu acho que o professor em que pese toda a necessidade de domínio da área específica dele, de atuação, ele precisa ter alguma formação na área de educação; não é uma coisa que é mágica; você deixa de ser profissional para ingressar no mundo da docência.

8.2.11 - acabei fazendo a trajetória específica da minha área que era o doutorado na área da saúde coletiva e eu senti que me distanciei um pouco dela enquanto espaço mais formal, de estudos, de aprofundamento, porque eu fiquei por um tempo ligada na área de educação.

9.1.01 - Não existe uma capacitação propriamente dita, antes de eu concluir a graduação fui trabalhar em uma área que não é de interesse de muitas pessoas.

9.1.02 - Por haver sido convidada pela diretora para compor o quadro de docente durante a graduação nós tivemos sorte em fazer a licenciatura e logo que eu conclui e fui fazer a residência em Ribeirão Preto dentro da área especifica daí que eu comecei a dar aula.

9.1.03 - a minha capacitação para a docência não tinha nada de especifica, não existiu capacitação efetivamente.

9.1 .04 - poderia falar de muitas coisas, até que eu já tivesse uma uniformidade de compreensão do que seria competência, mas pegando coisas simples, eu consideraria, conseguir estar na frente de uma classe e estar tranqüila e isso não ser uma coisa que te atemoriza, é uma competência e ela é boa, é imprescindível para o início do seu fazer.

9.1.05 - competência que já desenvolvi, acho que de uma visão educacional diferente, que ela me é funcional.

9.2.09 - fomos trabalhando eu fui trabalhando, fui ganhando experiência, amadurecimento, aliada às formações que a gente vai tendo, vai dando uma aprimorada neste fazer.

9.2.10 - eu fui fazer mestrado em educação e foi uma escolha bem intencional; naquele momento eu não queria fazer na área de atuação que achava que já tinha experiência e que o meu fazer era de docente, eu precisava de mestrado na área de educação, eu quis muito e pesquisei, não foi por facilidade ou localização, fui buscar na área de educação porque quis e acho que foi fundamental porque a gente vai entrando em contato com um conhecimento específico enquanto docente e foi possível amarrar o que a gente tinha de bom, aliar novos aspectos no nosso fazer.

9.2.11 - me lembro com muito carinho essa vivencia do mestrado, achei que foi muito bom em termos de formação para o que é uma profissão de ser educador. docência

$\checkmark$ Experiências no cotidiano profissional

$\checkmark$ Capacitação desenvolvida: domínio técnico, conhecimento científico, transmissão de conhecimento.

$\checkmark$ Aspectos facilitadores para a docência: formação na área de educação, vínculo do serviço com a escola, atuação como docente em disciplina de didática e em ações educativas com o enfermeiro.

$\checkmark$ Aspectos dificultadores: afastamento da área de formação.

$\checkmark$ Capacitação formal na graduação e após inserção na docência;

$\checkmark$ Experiências no cotidiano profissional

$\checkmark$ Experiências em após graduação na modalidade residência em enfermagem;

$\checkmark$ Capacitação desenvolvida: segurança em sala de aula, aprimoramento visão educacional;

$\checkmark$ Aspectos facilitadores para a docência: capacitação específica na área de educação experiência profissional. 


\section{CATEGORIA - A TEMPORALIDADE NA CAPACITAÇÃO DOCENTE: O PASSADO \\ SUB-CATEGORIA - A INFLUÊNCIA DAS CARACTERÍSTICAS PESSOAIS}

\begin{tabular}{|c|c|c|}
\hline $\begin{array}{l}\text { ENTRE- } \\
\text { VISTA }\end{array}$ & UNIDADES DE SIGNIFICADO & PONTOS RELEVANTES \\
\hline E-01 & $\begin{array}{l}\text { 1.1.07 - Quando eu estava na faculdade, as minhas colegas gostavam de estudar comigo, porque eu tinha uma facilidade de reprisar ou } \\
\text { revisar a matéria com elas e geralmente elas tiravam notas muito boas. } \\
\text { 1.1.08 - Eu tenho uma certa facilidade, eu acho, não dá para ignorar, uma certa facilidade de comunicação, de falar }\end{array}$ & $\begin{array}{l}\checkmark \text { Facilidade de revisar matérias } \\
\checkmark \text { Facilidade de comunicação, de falar. }\end{array}$ \\
\hline E-02 & $\begin{array}{l}\text { 2.1.01 - Eu vim da USP Ribeirão para a PUC. Lá, já notaram que eu tinha uma vocação para a docência. } \\
\text { 2.1.08 - Eu comprei livros de didática. } \\
\text { 2.1.11 - Mas muito eu já tinha de vocação. } \\
\text { 2.1.12 - Eu seria professora em qualquer profissão que eu tivesse. }\end{array}$ & $\begin{array}{l}\checkmark \text { Vocação } \\
\checkmark \text { Interesse em material de didático } \\
\checkmark \text { Convicção de ser professora }\end{array}$ \\
\hline E-03 & $\begin{array}{l}\text { 3.1.04 - Já aí me interessei por essa questão de poder compartilhar aquilo que já tinha passado, me capacitado de alguma forma; para } \\
\text { mim este é um ponto principal que me trouxe possivelmente agora, estar na docência em enfermagem. } \\
\text { 3.1.08 - Quando me formei eu tinha um desejo grande de ficar em um hospital universitário, um hospital-escola, até por conta de poder } \\
\text { verdadeiramente ficar vinculada a essa coisa de sempre estar em movimento com o aprendizado. } \\
\text { 3.1.10 - Eu fui trabalhar numa área de moléstias infecto-contagiosas e não me sentia preparada para uma área tão específica, eu lembro } \\
\text { que a gente tinha primeiro os próprios alunos graduandos de enfermagem que passavam com a professora e a gente tinha uma boa re- } \\
\text { lação, eu tinha uma boa relação com a professora, a gente trocava muito quando ela chegava ao campo, quer dizer quem que você a- } \\
\text { cha que poderia...estar interessante para os alunos e você acabando quase que ajudando nesse processo também, embora tendo a } \\
\text { responsabilidade da unidade. } \\
\text { 3.1.11 - Essa área ela reunia uma equipe de profissionais médicos e eles tinham muita clareza dessa necessidade da gente se inter- } \\
\text { relacionar, quer dizer cada um no seu aspecto profissional, as visitas que a gente fazia diariamente, era o médico, a enfermeira, tinha } \\
\text { um nutricionista e um farmacêutico, e a gente passava visita e havia exigência, que era você dar a conduta da tua área e foi quando eu } \\
\text { me vi com a necessidade imensa de estudar, de me aprofundar nas questões. } \\
\text { 3.1.12 - Eu voltei algumas vezes para a sala de aula tanto do curso de enfermagem, quanto do curso de medicina, porque a médica res- } \\
\text { ponsável era uma pessoa muito aberta e me convidava inclusive, para ir trocar experiências com os alunos da medicina. }\end{array}$ & $\begin{array}{ll}\checkmark & \text { Vivência como capacitação } \\
\checkmark & \text { Disposição para o aprendizado } \\
\checkmark & \text { Boa relação com docente da área } \\
\checkmark & \text { Relacionamento multiprofissional } \\
\checkmark & \text { Necessidade de trocar experiências }\end{array}$ \\
\hline E-05 & $\begin{array}{l}\text { 5.1.02 - Eu sempre gostei de ensinar na época de estudante, eu vivia ensinando alguém, sendo professora. } \\
\text { 5.1.04 - continuei com a vontade de ser docente e meio que na imitação dos meus professores, aqueles que eu considerava bons e eu ia } \\
\text { construindo uma referência do que era um bom professor e aí, praticamente este foi um primeiro modelo. } \\
\text { 5.1.05 - uma questão intuitiva, de repetição, como eu acho que acontece com a maior parte das pessoas. } \\
\text { 5.1.09 - À medida que isso foi avançando, eu fui percebendo que tinham elementos que eu não sentia segurança, embora eu tivesse sem- } \\
\text { pre um espírito aventureiro de arriscar a fazer coisas, mas eu sentia muito medo de não ter base. } \\
\text { 5.1.10 - eu comecei a me interessar, por conta de algumas leituras, meio que um autodidatismo, comecei a ler coisas sobre educação e a } \\
\text { pensar como é que isso poderia ser aplicado na minha área; isso foi aumentando à medida em que eu assumi a direção do curso, onde }\end{array}$ & $\begin{array}{ll}\checkmark & \text { Gostar de ensinar } \\
\checkmark & \text { Construção do modelo docente } \\
\checkmark & \text { Intuição, repetição } \\
\checkmark & \text { Espírito aventureiro } \\
\checkmark & \text { Insegurança, medo de não ter conhe- } \\
& \text { cimento. } \\
\checkmark & \text { Autodidatismo } \\
\checkmark & \text { Leitura sobre questões de educação }\end{array}$ \\
\hline
\end{tabular}


questões pedagógicas pareciam ser importantes e eu percebi que eu tinha uma ignorância ali perigosa ela era boa para mim, ela só encobria minhas necessidades, mas parecia perigosa em relação ao grupo que eu tinha que coordenar, empurrar para algum lado e eu tive...comecei a ter medo.

5.1.13 - no doutorado, eu fui mesmo para a área da educação e nesse lócus, eu comecei uma nova aventura: lendo, estudando me interessando e aí eu penso que isso me ajudou muito e dentro do ponto de vista formal. Uma fase que é bastante intuitiva, de reprodução, outra hora que eu me dou conta de que isso não é suficiente, especialmente quando percebo que isso prejudica ou interfere na vida de muitas pessoas e isso me faz pensar também na relação com os alunos.

5.1.19 - você tem que continuar buscando uma competência também para poder tornar aquilo possível para eles.

E-06 $\quad 6.2 .19$ - eu vim com uma competência no início e acho que a gente foi aprendendo, foi crescendo e foi vendo essa condição um pouco mais humanista, de tentar entender o aluno, de compreender esse nosso aluno trabalhador, de ver onde a gente pode motivar, ao invés de cobrar.

E-07 7.1.07 - Outra coisa que também considero importante que faz com que você se capacite, é o autoconhecimento e a autonomia intelectual.

E-08 8.1 .05 - a gente mesmo vai percebendo a necessidade de se capacitar, de se preparar, tanto na área específica, como trabalhar as questões da Educação. $\checkmark$ Estudo na área de educação

$\checkmark$ Interesse pela área de educação

$\checkmark$ Busca de competência

$\checkmark$ Disposição para entender o aluno

$\checkmark$ Compreensão em relação ao aluno trabalhador

$\checkmark$ Motivação

$\checkmark$ Auto-conhecimento

$\checkmark$ Autonomia intelectual

$\checkmark$ Percepção da necessidade de capacitação e preparo na área específica e da educação

\section{CATEGORIA - A TEMPORALIDADE NA CAPACITAÇÃO DOCENTE: O PASSADO}

SUB-CATEGORIA - A INFLUÊNCIA DA UNIDADE DE ENSINO

\subsubsection{6 - Não havia quem nos ensinasse aqui dentro.}

2.1.07 - Essa escola na época, tinha algumas assessorias, às vezes vinha professor dar didática que vinha de fora e eu me lembro que a Maria Eugênia foi uma figura muito importante para nós na ocasião, a própria D. Leonizia que era Diretora, que tinha algum conhecimento.

2.1.09 - A PUC oferecia cursos, porque era época de discussão do projeto pedagógico da universidade, a gente foi fazer o curso de capacitação pedagógica e eu entrei aqui dando aula em educação e saúde; aí que eu fui me aproximar desse processo de como aprender e como ensinar e de algumas práticas pedagógicas.

2.1.16 - Eu acho que nem o meu mestrado, nem o meu doutorado me ensinaram a dar aula e nem a escola contribui para isso, eu acho que a escola não me ajuda a fazer isso, a Instituição não me ajuda.

2.3.26 - A minha escola era muito retrógrada, mas eu acho que isso é um desafio que ficou aí para nós.

2.3.28 - Na minha escola existia uma apostila e é verdade eu não estou mentindo, todo o ensino de enfermagem fundamental era estudo

\section{PONTOS RELEVANTES}

$\checkmark$ Aspectos facilitadores para a docência: recebeu assessoria didática para professores, fez curso de capacitação pedagógica.

$\checkmark$ Aspectos dificultadores para a docência: não contribuição da pósgraduação para ensinar a dar aula, exigências desestimulantes da escola na época da graduação, inserção rígida em campo de estágio na época da 
dirigido; então se fazia aquela apostila e era para uma determinada aula. Tinha uma apostila que era para ditar como se portar, ou seja, a cor da unha a cor do esmalte, a cor da calcinha, a largura das pernas das calças, o comprimento do avental, a barra da calça para 0 sapato, e isso ficou muito pesado para mim, foi uma vivência muito pesada; eu tinha vontade de sair da escola diariamente.

2.3.30 - O processo de inserção no hospital foi muito sofrido, era muita rigidez, muita braveza, agente não podia sequer conversar com um médico na hora do intervalo.

E-03 3.1 .03 - Eles davam oportunidade para a gente, quando você estava no terceiro ano do colégio, tinha a possibilidade de fazer monitoria com os alunos do segundo ano, junto com o professor, acompanhando em campo, estágio, em laboratório o desenvolvimento das habilidades dos alunos.

3.1.07 - Quando vim fazer minha graduação, eu novamente me inseri numa monitoria.

3.1.09 - A gente tinha ainda aquela modalidade de habilitação médico-cirúrgica, que deve ter um sentido de qualificação.

E-04 4.1.02 - Eu já trabalhava na faculdade e depois de uns três anos, a PUC começou a oferecer alguns cursos de aprimoramento aos docentes, nos quais eles ensinavam os professores a elaborar, planejar, elaborar provas, desenvolver o senso de observação, se relacionar em equipe, então eu lembro que fiz vários desses cursos que eram de curta duração, mas foram muito importantes e me lembro que foram ministrados por docentes da educação da própria PUC

4.1.03 - isso foi muito importante, pois nos deu subsídios para que pudéssemos enfrentar a sala de aula.

4.1.04- porque a gente começou a dar aula sem nenhum preparo, depois que a gente foi se aprimorando.

E-05 5.1 .07 - Era mesmo uma questão de reprodução de práticas que eu achava interessantes, que à época, essas práticas me impressionavam muito pelo rigor técnico, pela clareza didática de explicar os conceitos.

E-06 6.1 .08 - minha vinda para a docência acabou sendo ao acaso, acabei saindo do hospital e vim para a escola pedir uma orientação profissional.

6.1.13 - aqui tinha capacitações docentes, tinha um grupo, tinha orientação pedagógica interessante, muita reflexão, então tinha alguns momentos que a gente foi revendo o processo de ensino então eu fui aprendendo com a prática e com esses momentos a gente foi crescendo muito.

6.1.14 - eu fiz o meu mestrado na área de educação, fui ver a função educativa do enfermeiro, com muitas leituras do aprendizado do adulto, da própria pedagogia e leitura de literatura para a própria tese, fui chegando, fui me enxergando, fui me encontrando e fui me capacitando através disso.

6.1.15 - No começo foi muito difícil, porque era uma outra área, mas me ajudou muito, com as disciplinas, foi muito bom para a minha capacitação.

6.2.18 - eu vim de uma escola muito positivista.

E-08 8.1 .06 - na Faculdade de Enfermagem, nós tivemos uma trajetória muito interessante, acho que tem que retomar o nome da professora Mara que ficou à frente da direção por 8 anos consecutivos e nessa época, coincidiu também com uma época muito fértil na Universidade, em que se trabalhou muito a temática da Educação, dos temas da Educação, do que é ser um professor, do que é uma educação graduação.

Aspectos facilitadores para a docência: fez monitoria em curso técnico profissionalizante e na graduação, qualificação na área específica na modalidade habilitação.

$\checkmark$ Aspectos facilitadores para a docência: curso de aprimoramento: planejamento, elaboração de provas, desenvolvimento de senso de observação, relacionamento em equipe, subsídio para enfrentar a sala de aula.

$\checkmark$ Aspectos facilitadores para a docência: reprodução de práticas consideradas interessantes pelo rigor técnico e clareza didática.

$\checkmark$ Aspectos facilitadores para a docência: busca de orientação profissional, grupos de capacitações docentes, recebeu orientação pedagógica, reflexão e revisão do processo de ensino e do desenvolvimento do próprio profissional, capacitação de mestrado na área de educação.

$\checkmark$ Aspecto dificultador para a docência: teve formação inicial: positivista.

$\checkmark$ Aspectos facilitadores para a docência: vivenciou discussões na Universidade sobre educação, ser professor, educa- 
transformadora.

8.1.07 - embora não existisse uma formação formal porque nós não éramos pedagogos, educadores na formação básica, nós tivemos a oportunidade de fazer essa discussão, a Universidade, a escola trazia uma série de palestristas, pessoas de renome Terezinha Rios, Paulo Freire, então a gente teve contato com pessoas de expressão no cenário nacional e até internacional na área de Educação. Isso contribuiu muito, isso foi dando um embasamento da área da Educação que a gente não tinha.

8.1.09 - Acho que tem que ter um preparo, uma discussão, é preciso que você conheça as propostas pedagógicas do seu curso, da instituição onde você está vinculado, projeto político pedagógico da instituição e entenda um pouco da Educação, das várias modalidades, das várias possibilidades de ensinar, de avaliar, que é uma temática bem polêmica, complexa a questão da avaliação, então, eu acho que precisa ter esse domínio.

E-09 9.2.06 - Nesse transcorrer eu acho que eu fui fazendo uma capacitação mais específica de transformação dentro da área e concomitante eu só não tive sorte, há muitos anos atrás a PUCC investiu muito nisso.

9.2.07 - nós fizemos todos os cursos que foram ministrados, com pessoas que eram referência na área da educação, tudo investindo na capacitação.

9.2 .08 - estes cursos contribuíram muito para atividade docente. ção transformadora, participou de palestras com profissionais da área de educação - embasamento da área da educação, conhecimento: projeto político pedagógico, propostas pedagógicas, modalidades de ensinar, avaliar.

Aspectos facilitadores para a docência: Investimento na capacitação específica, Fez cursos com profissionais de referência da área da educação, contribuindo para a atividade docente.

\section{CATEGORIA - A TEMPORALIDADE NA CAPACITAÇÃO DOCENTE: O PRESENTE SUB-CATEGORIA - A TRAJETÓRIA PROFISSIONAL}

\begin{tabular}{|c|c|}
\hline $\begin{array}{l}\text { ENTRE- } \\
\text { VISTA }\end{array}$ & UNIDADES DE SIGNIFICADO \\
\hline E-03 & $\begin{array}{l}\text { 3.2.28 - Por meio dos Congressos descobri o seminário nacional de ensino das diretrizes de ensino de enfermagem SENADEN, lá é o fó- } \\
\text { rum, lá é o espaço onde acontecem algumas discussões importantes para área do ensino. } \\
\text { 3.2.30 - Continuam as capacitações em termos de eventos que eu vá, direcionadas. } \\
\text { 3.2.31 - Participação em reuniões de escolas de enfermagem, porque é aí que se discute a questão de ensino de enfermagem, eu vejo } \\
\text { isso como uma capacitação, uma questão importante para continuidade ou para como minha capacitação ocorre hoje a própria questão } \\
\text { de estar na docência. } \\
\text { 3.3.47 - Eu nunca fui no evento da Rede Unida mas é um evento super importante que discute a questão da área de formação de profis- } \\
\text { sional da área da saúde que discute essa vinculação do Sistema Único de Saúde e acho que é uma coisa que a gente tem que ter cla- } \\
\text { reza, inclusive desse papel nosso de cidadão, de docente, como temos passados isso para nossos alunos, a quantas anda o compro- } \\
\text { misso social da enfermagem. } \\
\text { 3.3.49 - Acho que devemos repensar muita coisa..... competências que tem se discutido tanto, nós ainda estamos muito vinculado à uma } \\
\text { competência muito técnica que acho que tem toda sua importância não quero subestimar isso, mas tem outras questões a serem traba- } \\
\text { lhadas e principalmente essa coisa mesmo da articulação que o aluno tem que fazer com as questões, então eu acho que fica muito es- } \\
\text { vaziado eu acho que até temos uma proposta bem definida, importante mesmo para a formação, mas temos conseguido pouco alcançar }\end{array}$ \\
\hline
\end{tabular}

\section{PONTOS RELEVANTES}

$\checkmark$ Capacitação desenvolvida: aprimoramento específico na área de educação, práticas pedagógicas, avaliação, auto-avaliação, habilidade de compartiIhamento.

$\checkmark$ Aspectos facilitadores para a docência: educação continuada, aproximação ensino-serviço, participação em evento científico específico sobre ensino de enfermagem, reuniões de escolas de enfermagem. 
isso.

3.3.51 - Julgo que desenvolvi as competências de aprimoramento no campo específico da educação, em continuidade às questões relativas às práticas pedagógicas e avaliação, aprimorando neste segundo aspecto a auto-avaliação e também a habilidade em compartilhar a avaliação junto àqueles que têm recebido os alunos em campo de estágio.

E-04 4.3.24 - a gente vê que precisa crescer mais e a gente cresce todo dia.

E-05 5.2 .22 - Hoje, como tudo na educação é um processo; não poderia te dizer agora eu consigo, eu estou satisfeita com isso.

5.2.26 - eu percebo que eu começo a me perguntar: será que eu estou ensinando? Será que de fato eles estão aprendendo? Será que é um sonho muito longe do que é possível? Será que para o momento e agora também, eu não estou me excedendo?

5.3.33 - estou numa fase, no momento da curvatura da vara: voltando, mas voltando diferente, para um lugar que eu também não quero habitar do mesmo jeito.

5.3.34 - Acho que essa competência de uma transposição didática daquilo que permita, daquilo que eu sonho e que é muito amplo e é fluído para eles, de uma forma que eles sintam segurança e vão rompendo no limite deles aquilo que sei lá em quantos anos de profissão eu consegui fazer; eu acho que tenho que dosar isso. Acho que é essa competência que eu estou tentando. Como que estou fazendo? Experimentando.

5.3.40 - Acho que para o professor está mais difícil dele encontrar respaldo para essas práticas e o aluno, tem momentos que se surpreende com esse acolhimento, com essa disposição, com essa entrega que é a competência. A competência, sabe o que é? É entrega mesmo, está posta no outro, está no desejo que o outro e'... como posso te dizer... te faça de alguma forma, permanecer, quando tudo já passou.

E-06 6.2.20 - acho que essa competência, que estou desenvolvendo é muito voltada para essa outra visão não tanto positivista, mas, de construir, de dividir as responsabilidades, de trabalhar com ele, a gente vai amadurecendo: o quê que eu quero para essa vida, para esse profissional, que sensibilidade eu quero que ele tenha, como é que eu posso querer que ele seja um profissional dessa forma se eu não for assim com ele! Tentar mostrar também essa outra visão. Acho que seria uma visão qualitativa, integral, acho que uma visão holística.

6.2.21 - A capacitação hoje, tem ocorrido com a experiência também, acho que estou aberta para novos aprendizados, acho que prestando um pouco de atenção na prática da gente, porque só assim que a gente consegue melhorar, modificar.

6.3.26 - a gente já tem uma competência mais tecnológica, porque é um linguajar diferente, os jovens de hoje vem com outras exigências com outra experiência, de estar usando essa experiência deles no momento atual, o acesso à Internet, a informação tão rápida, qual que é a qualidade dessa informação? Como a gente pode usar isso, em benefício daquele conteúdo que a gente está ministrando, então, eu acho que teve essa competência que tem hoje e que não havia antigamente, do acompanhar essa tecnologia e o desafio é como a gente atrela tudo isso, lembrando que não é só a competência técnica, tem a crítica e como fazer isso.

$\checkmark$ Aspecto facilitador pra a docência: constatação da necessidade de crescer

$\checkmark$ Aspectos facilitadores para a docência: capacitação processual, reflexões sobre a prática profissional, vivência prática, vivências didáticas vinculada à idéia de acolher e reconhecer o desejo do outro.

Aspectos facilitadores para a docência: amadurecimento profissional, experiência, experiência profissional, abertura para novos aprendizados, avaliação da prática, divisão de responsabilidades, interação com aluno, visão qualitativa da prática profissional, atualização tecnológica e o uso dela. 


\begin{tabular}{|c|c|c|}
\hline & $\begin{array}{l}\text { 6.3.27-Que difíil! Porque é o antes, o agora e o depois! Fica um emaranhado porque você vai mudando e você não consegue mais saber } \\
\text { como é que você era antes, fica diferente esse olhar porque parece que você já era assim. }\end{array}$ & \\
\hline E-07 & $\begin{array}{l}\text { 7.1.04 - para ajudar essa capacitação, com certeza alguns cursos têm ajudado, que eu colocaria para você como aprimoramento e esse } \\
\text { seria através de um curso de especialização que o de metodologia do ensino superior que foi ministrado pela universidade, para todos } \\
\text { os docentes novos, dando algumas dicas de como deveríamos utilizar algumas estratégias em sala de aula, que era isso que nos dei- } \\
\text { xava mais assustadas no início. } \\
\text { 7.1.08 - acredito que o aluno ajuda a construir o seu conhecimento; esse é um vínculo que você estabelece e esse vínculo que faz com } \\
\text { que você cresça ou fique estagnado. } \\
\text { 7.2.14 - estou em um momento de achar que estou ainda neste processo de ensino/aprendizagem. } \\
\text { 7.3.16 - a capacitação ela vem sempre e sempre vai se processar com o outro. Não é uma coisa solitária, eu acho que essa capacitação é } \\
\text { uma autonomia tua, mas sempre vinculada a um grupo, uma coletividade, ao aluno, ao grupo de docentes, a própria ideologia que você } \\
\text { tem, de pensar que você quer realmente que se processe uma capacitação de ensino / aprendizagem que você queira realmente uma } \\
\text { coisa melhor para o aluno. }\end{array}$ & $\begin{array}{l}\checkmark \text { Capacitação desenvolvida: desenvol- } \\
\text { vimento de estratégias de ensino } \\
\checkmark \text { Aspectos facilitadores para a docência: } \\
\text { trabalho coletivo, ideologia do docente, } \\
\text { Capacitação para o ensi- } \\
\text { no/aprendizagem, aprimoramento so- } \\
\text { bre metodologia de ensino. }\end{array}$ \\
\hline E-08 & $\begin{array}{l}\text { 8.2.10 - A minha capacitação nos dias de hoje, dando continuidade na capacitação, na formação acadêmica foi o mestrado na área de e- } \\
\text { ducação. } \\
\text { 8.3.23 - fico pensando nas competências para ser professor, acho que a gente tem que estar atualizada, tem que estar antenada com tudo } \\
\text { que está acontecendo no mundo, tem que estar informado sobre tudo que está acontecendo na profissão. } \\
\text { 8.3.25 - é um papel de muita responsabilidade que a gente tem e para isso valer, tem que discutir com os pares, se posicionar, fazer a crí- } \\
\text { tica do momento atual, daquilo que está ocorrendo, isso dá um diferencial importante para uma educação que você não pretende que } \\
\text { seja só uma repetição, uma transmissão do conhecimento; que seja mesmo numa linha de promover uma autonomia intelectual para o } \\
\text { aluno, de contribuir para que o aluno seja realmente produtor de seus conhecimentos e seja alguém que vai fazer a transformação des- } \\
\text { sa sociedade, alguém que vai fazer a diferença, inserido naquele trabalho, naquela comunidade, acho isso fundamental. }\end{array}$ & $\begin{array}{l}\checkmark \text { Continuidade na capacitação: mestra- } \\
\text { do na área de educação } \\
\checkmark \text { Capacitação desenvolvida: promoção } \\
\text { de autonomia intelectual, atualização, } \\
\text { contribuição de conhecimentos, trans- } \\
\text { formação da sociedade. }\end{array}$ \\
\hline E-09 & $\begin{array}{l}\text { 9.2.13 - tem uma leitura hoje do processo educacional muito diferente, muito mais amplo do papel do professor, do que se espera do alu- } \\
\text { no. }\end{array}$ & $\begin{array}{l}\checkmark \text { Continuidade na capacitação: leitura } \\
\text { diferenciada do processo educacional }\end{array}$ \\
\hline
\end{tabular}

\section{CATEGORIA - A TEMPORALIDADE NA CAPACITAÇÃO DOCENTE: O PRESENTE SUB-CATEGORIA - A INFLUÊNCIA DAS CARACTERÍSTICAS PESSOAIS}

\begin{tabular}{c|c|c}
\hline $\begin{array}{c}\text { ENTRE- } \\
\text { VISTA }\end{array}$ & UNIDADES DE SIGNIFICADO & PONTOS RELEVANTES \\
\hline E-01 & $\begin{array}{c}1.2 .14 \text { - Eu verdadeiramente quero acreditar que o meu agir como professora, carregado de intencionalidade de transformação, possa es- } \\
\text { tar propiciando o desenvolvimento do compromisso com a transformação social, que possa estar convencendo os alunos que devemos }\end{array}$ & $\begin{array}{c}\text { Crença num mundo possível da trans- } \\
\text { formação social }\end{array}$ \\
\hline
\end{tabular}


colocar nosso trabalho a serviço do outro e que esse trabalho é uma prática social, da qual, os primeiros beneficiários devam ser aqueles excluídos da sociedade, estão mergulhados em sofrimento, seja este de que ordem for, mas que expressa o sofrimento de uma sociedade que clama por profundas transformações.

1.2.15 - Acho que a competência que estou desenvolvendo seja a de acreditar que outro mundo é possível.

1.3.16 - Eu não sei, acho que estou vivendo um momento ímpar da docência e não sei como ela deva ser, estou gostando como ela está sendo agora, sem muita preocupação com a minha performance, sem muita preocupação de que forma o aluno vai entender a minha figura ali, sem muita preocupação também se eu sou uma autoridade ou não, mas eu estou querendo estabelecer pela docência uma relação com conhecimento que necessariamente traga algo que eu acho essencial que é a ética no cuidado, isso para mim é o fundamental.

2.1.14 - Enfrentar uma classe de 80 alunos, como a gente faz aqui, tem que desenvolver certas competências, que eu não sei se são de professores, de um circense, de um juiz de um árbitro, eu não sei bem o que são! De um condutor de platéia, alguma coisa de domínio, de disciplina, de disciplinador, não bem de professor; de disciplinador.

2.1.15 - Saber como lidar, sem desrespeitar o modo que a gente acredita que seja o ensino, respeitoso para com o aluno e o ensino transformador verdadeiramente, trazendo esse aluno cada vez mais difícil, que não aprende limite na própria casa, nas outras que freqüentou e etc. Essas, eu acho que nenhuma escola ensina.

2.2.18 - Minha capacitação hoje, é de dois jeitos: a pessoal, é muito por interesse intelectual

2.2.19 - Existe a internet, formas de acesso, banco de dados, consultas on-line, muita informação. Então essa informação, ela vem até você, quer você queira, quer você não queira. Então hora ou outra você se depara com alguma coisa para ler, com alguma coisa para fazer, para escrever, o modelo de escola, até de novas metodologias de ensino, ou coisas da minha área ou coisas da minha profissão, de política, isso tudo te faz professor: filmes que você vai ver, música que você vai ouvir, conversas que você tem...

2.2.22 - eu me sinto muito instigada, mas eu nunca sei o que estou desenvolvendo, é muito estilo isso, não sei se estou desenvolvendo uma dada competência. Agora eu sei fazer isso, agora eu sei fazer aquilo. Para algumas coisas, sim é óbvio. Eu memorizei.

2.2.23 - é muito intuitivo, eu não sei que adquiri tal competência, mas eu sei quais competências meus alunos estão adquirindo noto no dia a dia ou no final do semestre, isso para mim é muito gratificante, principalmente porque eu tenho a felicidade de lidar com alunos de quarto ano; isso é uma experiência muito feliz.

2.3.25 - Competência... você acha que paciência é competência? Acho que paciência, o exercício da paciência, o exercício da alteridade, o exercício cada vez maior da paciência porque lidar com o jovem, para mim, é cada vez mais difícil; eu não tenho dificuldade de geração, não me sinto uma pessoa velha criticando a nova geração, até porque um dia eu fui a nova geração que estava lá numa escola completamente retrógrada.

E-03 3.2.25 - A capacitação hoje, embora não seja de maneira tão formal, é diferente você estar em uma estrutura formal, você fez uma especialização, faz um mestrado, faz um doutorado, eu falo que a gente fica meio órfã, é como se, agora você se tornou independente e eu vejo que é um desafio para você continuar fazendo alguma coisa. $\checkmark$ Intencionalidade de transformação

$\checkmark$ Crença da ética no cuidado

$\checkmark$ Não preocupação com status profissional

$\checkmark$ Ter domínio de grandes grupos de aluno

$\checkmark$ Disciplina

$\checkmark$ Ser disciplinador

$\checkmark$ Lidar com respeito o aluno e acreditar em ensino transformador.

$\checkmark$ Interesse pessoal e intelectual

$\checkmark$ Memorização

$\checkmark$ Intuição

$\checkmark$ Paciência

$\checkmark$ Alteridade $\checkmark$ busca de capacitação

$\checkmark$ medo de ficar desatualizada

$\checkmark$ busca de conhecimento 
3.2.26 - Tenho muito medo de ficar desatualizada, de repente uma professora que não sabe nem o que está acontecendo.

3.2.27 - Na medida do possível continuo saindo, eu comecei nos Congressos Brasileiros de Enfermagem a delinear o que eu ia fazer e ia nas reuniões das escolas, para ir ver os trabalhos de cenas maiores e o que estivesse voltado à educação é o que sempre me chama, afinal estou na área de ensino e aí tenho que estar.

3.2.39 - Percebo que a minha capacitação hoje ocorre por todos esses estímulos que eu continuo tendo e mais o desejo e a clareza da necessidade disso.

3.2.41 - Penso que nesta etapa tenho realizado auto-avaliação constante do meu trabalho e a busca de aprimoramento na área educacional elou de enfermagem, quer por meio de participação em eventos científicos internos ou externos à Universidade, têm proporcionado a aproximação com a questão de práticas pedagógicas e avaliação de ensino-aprendizagem.

3.3.42 - Estou num momento da minha vida que é pessoal também e tem a ver profissionalmente não se separa essas coisas, eu estou em uma fase muito especial sinto que é do amadurecimento, é um marco, tem uma coisa diferente. Inicialmente no campo profissional o que eu tenho feito aqui na escola que é o meu lugar maior de trabalho, sinto que na minha capacitação a continuidade se deu e vai continuar se dando enquanto tiverem essas pessoas no grupo ou em capacitação ou com essa vontade e desejo de também continuar se atualizando e vendo que isso é de suma importância para a docência, mas paralelamente eu tenho um momento que é um momento de querer mesmo ver nessas pessoas, a continuidade, eu não estou me achando velha e nem amadurecida, mas precisando fazer algumas outras coisas.

3.3.43 - Eu sou muito centralizadora, sistemática com as coisas.

3.3.44 - Eu acho esse amadurecimento importante....... para outras capacitações, sabe quando você se sente com a possibilidade de compartilhar outras coisas talvez em outros focos.

3.3.45 - Eu vou me capacitar em uma outra coisa, eu sempre tive o desejo e tenho tido dificuldade por ter que trabalhar muito, a gente trabalha demais.......... e eu preciso dessa capacitação, dessa qualificação de socializar um conhecimento que eu vejo que vou acumulando, acumulando e não que eu me ache com muito conhecimento, mas eu tenho um acúmulo em algumas coisas que eu precisava socializar e não tenho encontrado espaço para isso, para esse caminho, então isto é o que eu vou continuar fazendo, poder me capacitar nessa outra questão que é de produzir conhecimento.

3.3.48 - Tenho me questionado muito, o que a gente tem feito enquanto docente, bem ou mal quantos alunos passam pela gente, como temos discutido essas questões com os alunos.

E-04 $\quad 4.2 .6$ - minha capacitação hoje ocorre através do empenho pessoal, através de participação em cursos na minha área, participação em congressos, através de leituras e através dos cursos que a própria PUC oferece.

4.2.12 - eu tenho dúvidas e eu não tenho muito com quem trocar.

4.3.25 - Hoje, desenvolver a competência para o uso da informática por exemplo, é necessário e eu tenho muita dificuldade ainda e muitas vezes eu tenho que pedir ajuda para meus filhos, eu tenho dificuldade, mas acho que tenho que ter o domínio mesmo. $\checkmark$ desejo e clareza da necessidade de capacitação

$\checkmark$ auto-avaliação

$\checkmark$ busca de aprimoramento na área educacional

$\checkmark$ participação em eventos científicos internos e externos à Universidade

$\checkmark$ amadurecimento

$\checkmark$ desejo de coisas novas

$\checkmark$ centralizadora

$\checkmark$ sistemática

$\checkmark$ auto-questionadora $\checkmark$ empenho pessoal

$\checkmark$ participação em eventos científicos

$\checkmark$ leituras

$\checkmark$ Reconhecer dúvidas

$\checkmark$ Desenvolvimento de outras capacitações 

gada, respeitosa, ética, e que algumas vezes me leva ao limite quase de ficar frouxo, sem limites, porque eu quero apostar que os alunos aprenderão, então, eu não preciso de recursos mais autoritários, mais diretivos.

5.2.25 - Embora eu perceba o esforço enorme de estar cumprindo as competências e alargar horizontes, estabelecer conexão de informações, de conteúdos, estabelecer os diálogos com as diversas áreas, a dificuldade que eu tenho para fazer isso.

5.3.30 - hoje o meu desejo seria manter essa linha que eu acredito, trabalhar muito na base dos valores, da ética, do compromisso, de uma aplicação eu diria mesmo edificante dos conhecimentos para gerar atitudes, profissionais mais responsáveis, mais posicionados, mais comprometidos e a possibilidade de uma organização didático-pedagógica que permita que a gente faça isso e que tanto a eles quanto a mim dê a segurança de que alguma coisa aconteceu.

5.3.31 - estou entrando numa fase que estou tentando colocar um pouco mais de sistematização, para mim e para eles, principalmente para mim.

5.3.32 - se não tivesse a graduação, em classes grandes, em classes de meninos que não estão muito motivados, ou nem sabendo exatamente do que eu estou querendo falar e porque a minha urgência em falar dessas coisas, me causa um pouco de risco, então eu acho que preciso temperar um pouco.

E-07 7.2 .13 - agora eu percebo que não sou tão petulante e antes sim me achava o máximo e isso era muito confirmado esse máximo através de títulos, de ser paraninfa, etc.

E-08 8.3.20 - fiz a minha pesquisa e minha investigação por causa do doutorado, mas agora sinto que tenho esse compromisso com a continuidade de investigação científica.

E-09 $\quad 9.2 .12$ - tenho uma formação básica em enfermagem, mas a minha profissão, eu sou docente eternamente trabalhei assim.

$\checkmark$ Vontade de não ter regras

$\checkmark$ Prática docente dialogada, respeitosa, ética.

$\checkmark$ esforço

$\checkmark$ Critério para estabelecimento de informações, conteúdo.

$\checkmark$ Estabelecimento de diálogo

$\checkmark$ Sistematização no trabalho.

\section{CATEGORIA - A TEMPORALIDADE NA CAPACITAÇÃO DOCENTE: O PRESENTE SUB-CATEGORIA - A INFLUÊNCIA DA UNIDADE DE ENSINO}

\begin{tabular}{|c|c|c|}
\hline $\begin{array}{c}\text { ENTRE- } \\
\text { VISTA }\end{array}$ & UNIDADES DE SIGNIFICADO & PONTOS RELEVANTES \\
\hline E-01 & $\begin{array}{l}\text { 1.2.10 - Sem dúvida nenhuma o conhecimento, o estudo, o meu aprimoramento pessoal e profissional de certa forma foi dirigindo para um } \\
\text { determinado tema, me aprofundando numa determinada área de conhecimento. É um elemento facilitador, porque eu posso transitar } \\
\text { nessa área com muito mais facilidade sem dúvida alguma. } \\
\text { 1.2.11 - Tem uma coisa na docência que ela é além do que o conhecimento pode trazer, ela passa por outra dimensão que também não } \\
\text { sei dizer qual é... dessa interação, desse posicionamento em sala, dessa relação com o conhecimento, com momentos de tolerância } \\
\text { com momentos de exigências eu acho que é uma coisa para ser vivida mesmo, não sei se existe um modelo, não sei se existe uma pré- } \\
\text { determinação, porque a gente acaba também vivendo a docência com muita ressonância daquilo que a gente está naquele dia, porque }\end{array}$ & $\begin{array}{l}\text { Aspectos facilitadores para a docência: } \\
\text { obter conhecimento, estudo como ati- } \\
\text { vidade, condições para aprimoramento } \\
\text { pessoal e profissional, possibilidade de } \\
\text { aprofundamento do conhecimento em } \\
\text { área específica, interação em sala de } \\
\text { aula, posicionamento pessoal em sala, }\end{array}$ \\
\hline
\end{tabular}


nós somos gente como qualquer outro que tem dificuldades, alegrias, amores e dissabores como qualquer outro e que em algum momento interfere numa aula melhor.

1.2.12 - Existe algo na nossa profissão que ajuda muito na docência, nós temos uma vivência prática e esta vivência possibilita transitar entre a teoria e a prática e fazer estas ligações, e a prática alimenta teoria e alimenta aqueles exemplos e aquelas vivências e eu acho isso muito bom e ao contar essa vivência para os alunos, trazê-las com as emoções vividas e não apenas como mais um episódio que aconteceu na vida da gente como enfermeiro, mas, quais foram os sentimentos, as sensações, as dificuldades vividas naquele momento, e acho que isso faz com haja uma aproximação nesse momento do aluno quando ele pode olhar para a gente e falar assim: ela já cresceu e também tem dificuldade, ela já andou alguns quilômetros rodados e ela também tem medos, ela já se aprimorou formalmente com títulos e etc e também se vê em situações difíceis.

1.2.13 - A nossa profissão é uma profissão difícil, complexa, bela e eu acho que essa dimensão, essa coisa ampla faz com que nossos alunos consigam fazer uma parceria com a gente, e eu tenho percebido isso e tem sido muito melhor.

1.3.19 - O espaço da docência trás uma autonomia por mais que a instituição possa fazer amarras, quando você fecha a porta da sala de aula, ali não tem ninguém que roube as suas idéias, não tem ninguém que roube os seus princípios, ninguém faz isso nem é capaz de controlar, esse é o maior prazer que tenho de saber que não fui totalmente capturada.

E-02 2.2.20 - o campo de estágio suscita que você procure adquirir competências para poder ensinar os alunos; é discussão de caso, problemas que aparece para você, complexidade da realidade, do cotidiano, isso te instiga demais.

2.2.21 - tem uma coisa muito desanimadora que você não pode se deixar levar: outro dia na classe uma aluna não sabia o que era diletante; parece que eles não têm a curiosidade que a gente tem, ou que deveriam ter.

3.2.29 - Hoje até priorizo em relação ao próprio congresso, até porque às vezes não é possibilitado você sair, ou com as reposições que tem que fazer ou economicamente às vezes não é tão possível.

3.2.32 - 0 próprio aluno te instigando, a todo o momento, te perguntando, e hoje um aluno muito diferente com uma abertura outra, às vezes abre a Internet e vê uma coisa e quer compartilhar com você, ele também provoca essa capacitação contínua, aliás, ele é um teste.

3.2.33 - Outra questão é fazer parte de uma comissão de avaliação de projetos pedagógicos dentro da escola é uma coisa que exige muito de você estar mesmo inteirado com tudo que está acontecendo e não é só na área de ensino de enfermagem, é na área educacional até porque a gente começa a conviver com outras comissões de outros cursos da área da saúde nessa tentativa de tornar as questões mais coletivas, mais socializadas, isso acaba te estimulando tendo que buscar e você acaba muito atenta à todas questões inclusive de capacitação pedagógica.

3.2.35 - Muitas vezes há dificuldade de sair, mas sempre encontro um jeito, reponho ou faço de outra forma e também internamente a faculdade tem oferecido.

3.2.36 - Um ponto eu atribuo com muita importância. A importância de ter no grupo que você trabalha mais de perto que é a disciplina de administração de gerenciamento..... capacitação, então me vejo trabalhando com três pessoas, uma no mestrado e duas no doutorado, viver momentos de tolerância nas relações, viver momentos de exigências nas relações, reconhecimento do professor como pessoa com alegrias, amores e dissabores, vivência prática com expressão de sentimentos, sensações, dificuldades, parceria professor e alunos, autonomia em sala de aula.

$\checkmark$ Aspecto facilitador para a docência campo de estágio suscitando a aquisição de competências.

$\checkmark$ Aspecto dificultador para a docência: 0 não saber do aluno como algo desanimador.

$\checkmark$ Aspectos facilitadores para a docência: participação em comissão de avaliação de projeto pedagógico, convivência com docentes de outros cursos: socialização, coletividade, capacitação pedagógica, oferecimento de eventos internos da Universidade, programa institucional de iniciação científica, aluno instigando o professor, capacitação formal compartilhada com colegas, motivação para a busca, busca de capacitação, espaço universitário com recurso de biblioteca, orientação de 
então é assim, a todo momento estou recebendo; li esse artigo achei interessante, teve uma aula, as pessoas querendo compartilhar e eu fico pensando que preciso também ler isso, preciso me aproximar e sempre com a sensação que estou ficando atrasada e acho isso tudo estimulante, é na verdade o que mobiliza internamente, que te motiva a estar buscando.

3.2.37 - Eu não consigo te dizer de forma quadradinha como ocorre sua capacitação, porque do ponto de vista formal eu não sou vinculada a um curso único, tenho feito curso de extensão, mas tenho visto em todas essas coisas que se acontece agora, todo um processo que tem me capacitado ou que tem dado facilidade à minha busca de capacitação.

3.2.38 - E uma outra questão, desde que terminei o doutorado é que estou continuando com o meu projeto, de iniciação científica, nós temos o programa institucional de iniciação científica, porque como eu não sou professora de regimes de dedicação eu não tenho como fazer o pedido para órgão........ mas internamente a universidade tem esse programa e eu tenho conseguido manter por também ter alunos, que é outro estímulo.

3.2.40 - Ainda bem que estamos no ensino o tempo inteiro com a possibilidade de ir à biblioteca, vai com o aluno e aproveita também

3.3.46 - Eu vejo que tem muita coisa que você vai estudando, às vezes aqui na escola você orienta inclusive trabalho que não é da área de gerenciamento, então você vai aprendendo muita coisa, você busca até naquilo, o que tem lá de gerenciamento e é interessante porque os alunos ficam altamente envolvidos com essa possibilidade e também querem encontrar.

E-04 4.2.9 - acho que já desenvolvi o problema do trabalho em equipe que eu acho difícil e eu acho que isso iria facilitar para mim na sistematização da assistência, acho que é um desafio.

4.2.11- gostaria muito que na faculdade tivesse um órgão de apoio nesse sentido, um facilitador para isso, que dissesse; isso está adequado, isso esta errado, se seu objetivo está batendo com a introdução, não está batendo.

4.3.21 - O nosso tempo é muito restrito e a gente quer ler quer produzir e como não tem tempo isto frustra muito o professor, porque se ele não está na carreira docente, se ele não procurar por si mesmo produzir, ele vai ficando a parte.

4.3.22 - Como você vai achar tempo para produzir, publicar... porque a carga horária não permite, aqui, se a gente é contratado por 30 , trabalha por 45.

E-05 5.2.24 - percebo que em alguns momentos eu ensaio práticas inovadoras, eu ensaio processos de avaliação mais emancipatórios, eu entendo que chega num ponto em que os alunos não estão aparelhados para isto.

5.2.27 - muitas vezes os próprios alunos me fizeram rever, quando eles realmente pediam um pouco mais de organização, um pouco mais de controle, é como se eles quisessem ser controlados, por um modelo que eles dominavam melhor.

5.2.28 - essa coisa (prática inovadora) que podia me entusiasmar muito, porque eu podia viajar, eu podia ir longe, era muito desestabilizadora para eles e eles não reconheciam, eles não se sentiam seguros de que iam pelo caminho certo.

5.3.35 - estou na fase que o referencial teórico me dá tranqüilidade, ler, estudar, tudo isso é muito interessante, mas eu acho que estou naquela fase de experimentar na prática para ver onde vai dar. Brincar e fazer sempre a reflexão sobre isso. trabalhos científicos instigam a busca, 0 estudo.

$\checkmark$ Aspectos dificultadores para a docência: dificuldade de sair para eventos científicos, devidos falta de ajuda de custo e reposição dos dias afastados.

$\checkmark$ Aspecto facilitador para a docência: trabalho em equipe.

$\checkmark$ Aspectos dificultadores par a docência: falta de órgão de apoio para produção científica, tempo restrito para ler, produzir artigos.

$\checkmark$ Aspectos facilitadores para a docência: ensaio de práticas inovadoras, ensaio de processos de avaliação emancipatórios, revisão de organização e controle por ser instigada por alunos, experimentação, trabalho e encanto na atuação em pós-graduação, reflexão da prática, aprendizagem

5.3.36 - para mim não é muito difícil esse processo, porque ele gera sempre um trabalho no campo que estou fazendo hoje, que é a dis- 
cussão da docência.

5.3.37 - Como eu fiquei mais hoje professora universitária do que enfermeira, passou a ser um instrumento de trabalho a reflexão sobre essa prática pedagógica, que eu produzo, enquanto aprendo.

5.3.38 - Eu percebo hoje, numa fase em que eu volto a ser docente, docente no chão da fábrica, você está ali na sala de aula, saindo de uma pós-graduação, voltando para a graduação, eu posso dizer mesmo, sem medo de errar que é um lugar que eu voltei a me encantar, com a possibilidade que você tem nesses pequenos grupos de jogar com alguma coisa.

5.3.39 - eu diria, porque eu fiquei muito ligada a funções administrativas, que talvez a semente mais fértil ainda seja os alunos, porque por meio do que você investe neles, o retorno tem potencial, é uma promessa e eu percebo às vezes que muito do que você fala, faz sentido, não da forma homogênea, mas, faz sentido para alguns deles, diferente do que você as vezes vê, quando você está muito distante daquilo, você fala mas parece que é um discurso que cai no vazio.

E-06 $\quad 6.2 .22$ - acho que poderia ter uma capacitação hoje, uma troca maior, a gente não tem conseguido. Acho que como tivemos nos moldes anteriores, oficinas, os seminários que a universidade propunha e desenvolvia.

6.2.23 - Hoje a gente percebe assim, caminha e às vezes volta e retoma em alguns temas e fala: isso eu já ouvi há 15 anos, não é novo... e a gente percebe na enfermagem especialmente, a gente tem um grupo que tem uma história muito forte e que caminhou dessa forma. Então, às vezes a gente ouve sobre avaliação e todo mundo fica alvoroçado e nós da enfermagem já tivemos, já discutimos avaliação há muito tempo, nós já tivemos um ganho, um crescimento e a gente percebe outros pares quando a gente tem esse eventos que parece que é tudo tão novo e a gente já vem fazendo isso.

6.2.24 - eu gostaria dessa capacitação hoje, mais essa troca esse, caminhar conjunto, até uma análise, eu enxergo assim, mas será que é dessa forma? Como é que a gente pode estar trocando.

E-08 $\quad$ 8.2.13 - o que eu procuro fazer hoje para me desenvolver enquanto docente, é me inserir nos grupos de discussão que a universidade promove, participar de palestras da área, cursos de capacitação que a universidade hoje está oferecendo, fazer algumas leituras da área.

8.2.14 - tem outra questão que me preocupa, que é a forma como o jovem chega na universidade e como hoje a sociedade está valorizando o jovem com acesso ao mundo da informática, eu vejo que a gente compete um pouco a atenção dele, aquelas aulas por mais que você queira avançar e tudo mais, a competição com o mundo da Internet, as informações, a questão da agilidade de conhecimento e tudo, é difícil.

8.2.15 - o que atrai mais? são quatro horas sentado num banco escolar ou quatro horas na frente da Internet navegando acessando uma série de sites, se comunicando com o mundo. Então, eu acho que é um desafio que está colocado para o professor hoje e para as escolas.

8.2.16 - Como é que a gente consegue acompanhar isso, mas mantendo o nosso ensino, os conteúdos que tem que ser trabalhados e induzidos, mantendo a preocupação com a produção dos conhecimentos para esse aluno, que pode ser de repente por Internet uma série de trabalhos que pode ser um corta e cola ? Prontinho, sem ter feito uma leitura, uma crítica, então... são riscos do mundo atual que

$\checkmark$ Aspecto facilitador para a docência: grupo da enfermagem com trajetória em desenvolvimento de recursos humanos.

$\checkmark$ Aspecto dificultador para a docência: falta de cursos, oficinas, seminários para capacitação

$\checkmark$ Aspectos facilitadores para a docência: participação em eventos que a Universidade oferece, leituras sobre a área., acompanhamento de desenvolvimento tecnológico, compromisso com a formação contextualizada.

$\checkmark$ Aspectos dificultadores para a docência: falta de condições para pesquisa carreira docente, competitividade e desafio frente ao ambiente virtual junto ao jovem. 
a gente tem que enfrentar.

8.3.19 - a gente tem poucos professores em carreira, poucos professores fazendo pesquisa.

8.3.24 - nós temos esse compromisso de situar o aluno na profissão que ele abraçou, que ele escolheu, situar essa profissão na sociedade, contextualizar na sociedade em que a gente vive, num mundo contemporâneo.

E-09 $\quad$ 9.2.14 - essas competências por mais que a gente ache que já adquiriu, muitas delas a gente tem habilidade para usar com grupos menores, em campos de estágio, em pequenos grupos; daí você é o professor com mais competências, da leitura do que 0 aluno diz, da solicitação do papel que você espera dele como um elemento mais ativo na construção do conhecimento.

9.2.15 - em termos de competências, eu vejo assim, dividido: o professor do pequeno grupo e o professor da sala de aula.

9.2.16 - O professor da sala de aula, por mais eu sei o que seria bom para ele, não me sinto competente para desenvolver bem isso. Me sinto perdendo do que eu sei que consigo fazer num pequeno grupo, que é ter objetivos, que eu acho que são concernentes a uma leitura do papel do educador hoje e que consigo fazer bem isso, no campo de estágio, num grupo de 10, 15 alunos ou até 20, mas, com 80 eu não tenho esta competência.

$\checkmark$ Aspectos facilitadores para a docência: atividade profissional em estágios, pequenos grupos, experiência positiva do professor com pequenos grupos, experiência do professor em sala de aula.

\section{CATEGORIA - PERSPECTIVAS E INCERTEZAS: O FUTURO}

ENTRE-

VISTA

1.3.17 - A docência para mim é uma ferramenta, quantas vezes eu precisar mudá-la eu vou mudar para fazer com que esse princípio da ética do cuidado caiba nela.

1.3.19 - Lá na frente eu não sei como será, o que não posso é perder o eixo fundamental que é a ética do cuidado, eu não sei como ela vai acontecer, pois ela simplesmente está acontecendo.

1.3.21 - Eu não consigo ver competências individuais, acho que as competências coletivas são aquelas que melhor representam o pulsar dos sonhos, desejos, crenças, projetos e habilidades.

1.3.22 - Não sinto necessidade de desenvolver habilidades individuais, sinto necessidade de desenvolver habilidades coletivas, integradoras, complementares, com cumplicidade.

E-02 2.3 .24 - Eu gostaria futuramente de dar aula num curso de pós-graduação.

2.3.27 - Então como é que a gente vai inventar o ensino que vai suscitar o desejo de aprender nessa juventude que vem aí.

2.3.35 - Acho que a gente teria que desenvolver como competência, poder estar ensinando de forma mais aprazível, poder estar ministrando de forma mais aprazível eu tenho pensado muito nisso, ensinar dessa forma em qualquer nível. Agora para essa competência eu não sei.

\section{PONTOS RELEVANTES}

$\checkmark$ Perspectivas: mudanças contínuas para preservação da ética no cuidado, competências e habilidades coletivas, integradoras, complementares e com cumplicidade.

$\checkmark$ Incertezas: não se sabe como será o futuro.

$\checkmark$ Perspectivas: dar aula num curso de pós-graduação, ensinar de forma mais aprazível.

$\checkmark$ Incertezas: como inventar o ensino que suscite o desejo de aprender na juventude

$\checkmark$ Perspectivas: continuidade de ofere- 
dagógica, mas eles já tem oferecido algumas coisas e dentro do possível tenho participado, então vou, já fui em congresso, em curso de capacitação para docente, pedagógico, então aproveito.

3.3.50 - Quando você começa a vida você vai para todos os cantos e vai ficando mais seletivo, mas não seletivo no sentido de ficar de criar espaços diferentes, mas seletivo no sentido de direcionar o que você tem que fazer. Então eu acho que a minha capacitação nesse momento que eu vejo que é maior que eu tenha que fazer, é dar continuidade ao que eu tenho feito na minha área de atuação, mas eu preciso socializar.

E-04 4.2 .10 - Eu gostaria de desenvolver a competência de ter mais facilidade para redação, tenho um pouco de dificuldade em escrever um trabalho científico, de escrever, de colocar as palavras adequadas.

4.3.20 - acho que precisa a Instituição investir mais no docente porque acho muito difícil, não o fato de você. ter que pagar o curso que vai fazer, mas o que me deixa muito chateada é a dificuldade que a gente tem de sair para fazer esses cursos, para trazer o que é bom para aluno, e quando chega aqui não só tem que repor tudo, mas é muito burocrático, o negócio é muito burocrático, parece que ele não favorece nada ao docente e isto é muito desestimulador.

4.3.23 - Eu acho que a gente está sempre precisando desenvolver nossas competências, só sabe das competências que a gente não desenvolveu, quando se depara com situações.

E-05 $\quad 5.3 .30$ - hoje o meu desejo seria manter essa linha que eu acredito, trabalhar muito na base dos valores, da ética, do compromisso, de uma aplicação eu diria mesmo edificante dos conhecimentos para gerar atitudes, profissionais mais responsáveis, mais posicionados, mais comprometidos e a possibilidade de uma organização didático-pedagógica que permita que a gente faça isso e que tanto a eles quanto a mim dê a segurança de que alguma coisa aconteceu.

E-06 $\quad 6.3 .25$ - A continuidade, acho que seria nessa linha mesmo, acho essa última pergunta mais difícil de responder porque, que competências que a gente acha que deve desenvolver, a gente só sabe o que deve desenvolver se a gente tiver consciência delas então acho que o que desenvolver já está tentando.

E-07 7.3.17 - o processo educacional é um processo de transformação que a gente almeja, quando se fala em continuidade, é ter essa autonomia intelectual para dar alguns lampejos de luz e para gente construir em conjunto.

7.3.18 - acredito muito que a construção da capacitação deva ser interdisciplinarrmente; se você não tiver essa coisa interdisciplinar, sozinha com meu conteúdo não vou conseguir construir muita coisa nem me capacitar muito.

7.3.19 - com o seu conteúdo, com o conteúdo da outra professora, a gente vai juntando, formando um ser humano um pouquinho melhor.

E-08 8.3.17 - Eu sou defensora daquela idéia de que a gente tem que estar a vida inteira aprendendo. Aprendendo profissionalmente, pessoalmente. 3

8.3.18 - uma área que eu precisaria me dedicar mais, seria a área da pesquisa. Eu acho que isso poderia inclusive, qualificar meu trabaIho, permitir a inserção de mais alunos no projeto de pesquisa, no projeto de iniciação científica dentro da escola, então a gente é um cimento pela Universidade de capacitação pedagógica, socialização de conhecimentos.

Perspectivas: competência para redação, incentivo da escola para participação em eventos externos, desenvolver nossas competências.

$\checkmark$ Perspectivas: trabalhar tendo como base, valores, ética, compromisso, aplicação de conhecimentos gerando atitudes profissionais comprometidas com a organização didático-pedagógi$\mathrm{ca}$

$\checkmark$ Perspectivas: conscientização das competências que necessitam de desenvolvimento

$\checkmark$ Perspectivas: ter autonomia intelectual, construção conjunta e interdisciplinar.

$\checkmark$ Perspectivas: estar continuamente aprendendo, dedicação na área da pesquisa e da iniciação científica, investir na questão da publicação a partir de 
pouco tímida ainda nisso.

8.3.21 - preciso trabalhar a questão de publicação, acho que é uma área muito frágil, na minha vivência, na minha trajetória profissional e que eu preciso investir nisso. Acho que isso é bom para mim, para a escola.

8.3.22 - na questão da publicação, acho que começar a documentar, a gente ter preocupação com o registro com o trabalho que a gente faz. A gente passou, evoluiu bastante, mas a gente ainda trabalha bastante e registra pouco o que faz.

E-09 9.3.17-Capacitação é a tal da coisa inconstante... não só para docente, para área especifica.

9.3.18 - estamos num mundo em movimento e movimento rápido, então acho que as pessoas aprendem a ser desse jeito, vivem fazendo buscas.

9.3.19 - hoje sou uma pesquisadora, tenho que fazer pesquisa, acho como já te falei, a maturidade te dá uma condição de buscar outra ordem, outro tipo de literatura, então, eu acho que a gente está em continua capacitação.

9.3.20 - dada às transformações a gente tem de vivenciar coisas novas, um jeito novo de ser e quando se dá conta, surpreendentemente, vagarosamente, você mudou, cresceu.

9.3.21- A gente tem que continuar, então, eu acho que é continuo não tem muito que pensar a idéia da capacitação para qualquer atividade, então, é para sempre essa capacitação.

9.3.22 - O que eu precisaria desenvolver talvez, seria mesmo competência para lidar com grandes grupos que eu ainda não sei e é por muito tempo, que eu aprendo coisas teóricas, cursos, leituras e acho que elas não me dão essa proteção, não é esse conhecimento que me dá essa habilidade. registros da nossa prática.

$\checkmark$ Perspectivas: contínua capacitação, vivência de coisas novas, desenvolver competência para lidar com grandes grupos.

$\checkmark$ Incertezas: capacitação como algo inconstante 


\section{ANEXO 9}

TRANSCRIÇÃO DAS FALAS DO GRUPO FOCAL - 2ª FASE 
Grupo Focal 28/04/2006.

Início: 11:30 h

Término: $13: 00 \mathrm{~h}$

Número de participantes: 06

1 Facilitadora (pesquisadora)

1 Observador (professor do curso de Enfermagem)

O grupo recebeu informações sobre a técnica de grupo focal, assinou o Termo de Consentimento Livre e Esclarecido e foi registrada a caracterização dos sujeitos participantes.

A explicação e orientação dada foi a de que deveriam elaborar um constructo coletivo segundo o entendimento dos significados aprendidos a partir da leitura individual da síntese apresentada, resultante da análise das falas resgatadas nas entrevistas com os docentes, na primeira fase da pesquisa. Para este momento coletivo, foram utilizados retalhos de tecidos, cola, cartolina e tesouras.

Após a reunião do grupo focal, foi realizada a transcrição, na íntegra, das falas dos sujeitos, e foram incluídos os gestos, as emoções e outros elementos que foram captados pela facilitadora e pelo observador, que aparecem no texto entre parênteses, observando-se que os nomes das participantes do grupo focal foram substituídos por nomes fictícios.

O grupo desenvolveu a tarefa mantendo a temporalidade segundo as vivências do passado e do presente e a perspectiva do futuro.

\section{O Passado}

Rosa retira os retalhos de tecido de dentro da caixa e diz: eu preciso ver tudo senão como é que eu vou né? Seguido de risos do grupo.

Rosa encontra um tecido preto e diz: nossa! Tem até um preto aqui!

Violeta responde: é...é o início de tudo!

Lírio fala: eu queria colocar o que significa isso para mim. Eu vejo que quando se começa a atividade docente, é tudo muito pequeno, você é pequena e com o tempo você vai crescendo, você vai construindo. É um fio só, é uma coisa que você vai trilhando, você vai juntando e vai evoluindo. Quando você inicia, esse caminho é muito estreito e com o tempo vai se abrindo, vai se alargando. No início é estreito e meio preto mesmo, você nem sabe para onde ir. Isto tem muito significado.

Violeta pergunta para o grupo se este seria o início da construção coletiva.

Rosa responde: não dá para fechar, esta é uma idéia dela (lírio) eu sugiro que cada um possa falar sobre o passado e fazer a representação com os retalhos. A não ser que este já seja um início.

A facilitadora intervém perguntando ao grupo se é senso comum que a representação do passado inicia com um caminho estreito.

Estrelitza responde: não sei! Para mim não! \{desde que foi oferecido os retalhos esta foi a única que se deslocou do lugar, permaneceu em pé, escolheu um retalho nas cores branca e rosa e trabalhando nele, transformou-o em um laço\} Inicia sua fala: eu era uma garotinha tão bonitinha, tão dengosa, de laço de fita entendeu?! E quando eu comecei, eu tinha todas \{ênfase nas fala\} as possibilidades. Então, eu vejo assim com carinho, com a alma. Não havia problema, havia ingenuidade, havia eu comigo e meus desejos.

Miosótis diz: eu estava aqui escolhendo um retalho e assim: começar a dar aula sempre foi o quê sempre quis, era o que me excitava profundamente, eu não tinha medo não! Eu queria fazer laços \{pausa\} fazer laços, não imaginava como. Era legal naquela época quando comecei aqui, porque acho que ninguém sabia direito como é que era, talvez como a Lírio falou, mas eu cheguei onde queria.

Lírio interrompe Miosótis e diz: sabe o que é, talvez eu não tenha me explicado bem, mas na época, eu vim para o Brasil debaixo de um golpe militar no Chile, e é um momento de muito \{pausa\} muitas marcas, de sofrimento e eu saí correndo, não foi fugida, nada disso, mas é lógico que é uma coisa muito sofrida porque era uma coisa que te impunha, uma situação diferente, então, por isso o caminho estreito. Então comparado com o início da Estrelitza que foi muito legal, mas o meu foi muito sofrido.

Rosa diz: Eu peguei um tecido aqui, bem colorido, porque agora vendo a síntese, me fez recordar, porque eu fui entrevistada também. Quando houve a entrevista eu peguei meu percurso desde o técnico, passando pela experiência como enfermeira em uma unidade de internação, com um momento rico de compartilhar com alunos, professores e também num momento de explodir mesmo, em conhecimento e veio mesmo a chance oficial, concreta, então, para mim 
também foi muito bom poder iniciar e colocar em prática tudo aquilo que eu já acreditava e que vinha da minha experiência do hospital universitário. Bom, depois a gente vê o presente, mas o passado é algo muito mesclado e muito colorido. \{risos do grupo\}.

Margarida diz: quando eu comecei, quando me formei, eu tinha uma visão muito ampla, eu achava que tinha que buscar residência, buscar pós-graduação, especialização em obstetrícia, UTI, fui para Unicamp como aluna especial na enfermagem, na medicina, eu achava que tinha que saber tudo. Então foi um caminho de busca e que a contribuição foi importante, mas, você tem que afunilar isso e até entender isso, eu demorei muito; então meu tecido aqui, é este, bem longo.

Violeta diz: no meu caso, tenho dois momentos de docência: um começa na graduação quando eu era monitora e que naquela época a gente tinha uma responsabilidade que é muito diferente de hoje, antes, a gente dava aula. Você imagina eu com 19 anos dando aula para uma sala de alunos da graduação? Nossa! Hoje, eu fico imaginando o que foi esse momento, a gente não tinha a menor noção do que se sabe hoje. Depois, quando eu vim para cá, que era uma coisa que eu queria sim, era algo muito escuro, eu não sabia e nem queria repetir aquilo que vivi aqui. Então docência era assim, tem luz aqui, mas eu não enxergo \{aponta para um retalho preto\}, eu não estava preparada, não tinha embasamento para fazer aquilo que eu achava certo, não me sentia segura.

Rosa retoma: interessante você falar isso porque me faz lembrar que eu também senti necessidade de buscar mestrado em Educação e era um momento de insegurança e muita angústia.

Estrelitza diz: Eu estou ouvindo vocês falarem e gostaria de dizer que este rosinha que aponto aqui \{no laço feito no retalho\} é a minha identidade como enfermeira e não como docente. Eu cheguei aqui na Universidade como enfermeira.

\{Miosótis retoma, pedindo à Rosa que ajude a encontrar um tecido bem desbotado\} e diz: eu queria passar uma coisa de medo e até de vergonha, que foi quando dessa coisa minha, acabou sendo de ser a diretora \{da faculdade de enfermagem\}. Porque aí fui me dar conta de que eu podia saber para mim, me achava desafiada, podia errar, acertar, de achar que era um problema meu, dos alunos, eu não tinha a real dimensão. Aí, quando apareceu essa coisa de ter que estar falando, eu sentia vergonha, porque não me sentia preparada, me sentia muito mal e, eu descobri que na verdade, eu não sabia, demorou isso, porque naquele momento não era moda, não tinha uma exigência de capacitação, você aprendia fazendo, mas quando você passa a perceber \{pausa\} Nossa! E agora? Eu me sentia sozinha, perdida, eu tinha medo.

Lírio diz: eu acho legal a Miosótis falar isso porque eu acho que sou a mais velha aqui, e me recordo que quando cheguei, eu me achava o máximo \{risos do grupo\} apesar de tudo que passei, o caminho estreito, eu me achava o máximo. Até cair a minha ficha, olha! Demorou!

A facilitadora intervém, perguntando se alguém quer colocar mais alguma coisa em relação ao que foi lido na síntese. Como não houve pronunciamento, a facilitadora pede para encerrar o momento do passado com uma frase ou palavra que representasse aquele momento e as palavras que surgiram foram: persistência, vida, felicidade e diversidade.

\section{O Presente}

A facilitadora continua com a intervenção propondo uma nova leitura da síntese no que diz respeito ao presente e mantém a consigna proposta no início da reunião, orientando ainda que se sintam à vontade em relação à disposição das cartolinas, retalhos e cola.

\{Após a re-leitura da síntese, o grupo desloca a cartolina contendo os retalhos com suas representações sobre o passado para uma extremidade da mesa e retomam as escolhas dos retaIhos, mas, de forma mais coletiva, analisando e escolhendo as cores e inclusive dividindo (cortando o tecido ao meio)\}

A facilitadora chama a atenção para este momento com a seguinte frase: Ah! Já estão começando a compartilhar no presente?

Estrelitza \{se levanta vai em direção à cartolina do passado e a recoloca no centro da mesa, próxima à cartolina que representa o presente\} diz: olha eu carregando todo mundo aqui outra vez!

Violeta pergunta: porque você trouxe o passado de volta?

Estrelitza responde: eu não consigo desvencilhar, olhar assim tão certinho até porque eu estou colada aqui \{risos do grupo, ressaltando que a Estrelitza foi a única que colou sua representação - o laço, na cartolina\}.

Rosa diz: eu vou continuar, essa é uma coisa que eu estava refletindo esses dias com uma pessoa, que eu vejo que permaneço com essa coisa muito mesclada até porque, do passado até o presente, essa busca de aprimoramento, a oportunidade que surgiu aqui, mas, eu queria acrescer esse daqui \{mostrando outro tecido\} por que assim, apesar de todas as dificuldades, 
eu preciso encontrar o prazer, senão não estou na minha, e, no trabalho que a gente vive tanto tempo e aí, para representar essa coisa de satisfação de felicidade, eu escolhi essa cor amarela, que eu gosto muito. Então quis carregar isso porque para mim tem a representação mesmo, que embora todos os empecilhos, porque eu acho assim, aí talvez entre como a Estrelitza falou, pega todo o passado com percalços e tudo, mas eu sinto que não consigo perder essa mescla de busca e essa felicidade, senão não estava aqui, porque eu preciso dessa felicidade desse prazer pra viver mesmo. Eu não vou por lá \{referindo-se à cartolina do passado\} mas vou por assim percorrendo \{dispondo o tecido entre as cartolinas do passado e do presente\}, porque é assim que está acontecendo.

Lírio diz: Eu acho que vou colocar, mas outra cor, porque a gente está sempre mudando e eu coloco o azul \{referindo-se ao tecido\} porque para mim representa a esperança, desafio, é aquela coisa da busca e o amarelo \{coloca outro tecido\} é a busca do brilho é com esse brilho que a gente se mantém viva, porque é tanta coisa obscura, escura, tormento, então tem que ter um momento de sol também, mas de repente, eu vejo tudo muito carregado e esse amarelo meio encoberto \{nesse momento Lírio colocou um tecido preto sobre o amarelo\}. É um momento meio nebuloso, de muitos desafios \{pausa\} não é muito, mas o sol continua aqui briIhando \{remove uma parte do tecido preto sobre o amarelo\}.

Margarida diz: eu coloco o azul porque eu continuo com a busca da capacitação, eu estou me capacitando, apesar de algumas inseguranças e o azul representa tranqüilidade de perspectivas e o grupo se ajudando, se comunicando \{pausa\}.

Miosótis diz; acho que essa mistura (refere-se a uma mescla de tecido vermelho e preto), esse caos \{pausa\} tem coisa do passado, tem um olhar, mas misturado acho que ainda tem um pouco dessa \{pausa\} o que é isto? Mas é interessante porque ao mesmo tempo eu acho que o presente me faz voltar à raiz das pessoas. \{após a última pausa, a fala foi embargada de emoção e choro; o grupo ficou sensibilizado, com alguns membros compartilhando o choro\}

Violeta diz: Então deixa eu colocar; é assim, eu coloca o azul também, porque para mim é tranqüilidade e os pontinhos pretos aqui em cima, são algumas dúvidas, algumas incertezas e acho que estarão sempre presentes, independentemente de estarmos sempre buscando, tentando, ousando e esta é uma palavra que aprendi com a Miosótis durante minha orientação e quem não ousa, não cresce, não faz nada, então, é uma que marcou muito e esses rosinhas \{referindo-se aos pedacinhos de tecidos recortados e sobreposto no tecido azul já com os tecidos pretos\}, são momentos de muita tranqüilidade, de certezas também de momentos legais.

A facilitadora faz uma intervenção com a fala: eu gostaria de saber deste grupo uma vez que vem aparecendo desde o passado e agora no presente, esses medos, essas incertezas, o que são? Sentimentos? Influências? É uma ameaça? De quê ou de onde?

Estrelitza diz: não sei, quando eu peguei esse passado \{referindo-se à cartolina\} e trouxe para cá \{refere-se ao presente\} eu era uma enfermeira, bonitinha, magrinha, quando eu vou virando uma docente, eu vou virando com um pouco de cada uma \{aponta para o grupo\}, porque eu vou vendo e ouvindo a Miosótis como diretora empurrando a gente: vamos estudar, vamos, então eu fui aprendendo muito, com um, com outro. Esse grupo era muito forte e fui aprendendo. Hoje, no presente eu sou tudo isso aqui \{aponta para a cartolina\} porque eu gosto de ser o que as pessoas me ensinaram a passar a ser. Eu não busquei uma capacitação formal. Hoje, não me acho a professora, nem quero mais ser o docinho. Eu utilizo dessa docência para defender a saúde pública, eu tenho uma relação muito clara com a minha docência, então eu continuo me sentindo..., por isso que estou presa aqui \{aponta para o passado na cartolina\} porque sou uma enfermeira de saúde pública e para fazer saúde pública eu uso a PUCC \{ênfase\}. Eu uso a PUCC para defender o SUS. Não estou interessada em ser reconhecida como a \{ênfase\} performance. Estou sendo super sincera gente, porque se não for sincera aqui não tem sentido. Acho que estou de bom tamanho para transmitir o que transmito.

Violeta solicita espaço ao grupo para perguntar se alguém não se sente enfermeira neste grupo.

Miosótis responde: não sei. Eu acho interessante porque atualmente eu me sinto cuidadora... é um conceito.

Violeta diz: nós somos docentes, estamos discutindo isto aqui e não dá para separar essas coisas. Quando está se orientando o aluno aqui de enfermagem, essa coisa da enfermeira não tem como separar. Então, é como você falou \{referindo à Estrelitza\} que você usa a PUCC para fazer saúde pública, a gente está aqui fazendo transformação social, não é isso? E defendendo o cliente cirúrgico, defendendo o outro, cada um no seu espaço.

Estrelitza intervêm: mas não consigo colocar numa ordem de grandeza. Porque é um lócus meu, minha primeira escolha foi aqui \{aponta para o passado na cartolina\}. Então, eu fico imaginando que eu fui melhorando, eu estou melhor hoje de que quando cheguei, mas melhorei por causa disso aqui \{aponta para toda a trajetória na cartolina\} e eu continuo aproveitando o 
que vocês produzem, do que vocês evoluem e, aí eu me incluo no bolo também. Não é uma coisa individualizada, entendeu? \{voz embargada pela emoção e choro\}. Então, não é que eu estou presa no passado, mas meu presente é tudo isso aqui \{novamente aponta para a trajetória na cartolina\}

Rosa diz: acho que quando você fez a pergunta facilitadora, da fala da Lírio, quer dizer, de onde vem essas incertezas, as angústias, eu acho que tem um fator muito importante que é a relação trabalho quando ele está institucionalizado e, nós todos somos institucionalizados. Aqui ou acolá e isto tem uma influência muito grande, você estar institucionalizado, porque assim, a vida acontece na relação com o trabalho e, você está dentro de uma instituição. Então acho que até neste momento, em que a Lírio diz desse ir e vir, ela está sendo influenciada no âmbito em que você convive, que é institucional, então, eu acho que até para você sobreviver aqui de maneira geral, quando você bate o olho, embora tenha os momentos mais obscuros e de maior indefinição, predomina a idéia da clareza da vontade do querer, entendeu? Quer dizer, a gente quase que resistindo e, como a Margarida fala, essa coisa da persistência.

\section{O FUTURO}

A facilitadora volta à síntese na tentativa de retomar as questões.

O grupo decide estender a cartolina para tratar do futuro.

Estrelitza diz: eu vou continuar empurrando daqui \{apontando para o passado\}. Não sei se quero me desenvolver mais, não tenho clareza disso; tive alguns momentos formais que a instituição promoveu, você vai captando, mas não consegui me sentir... plena de competência. Não é isso, mas não sei se há alguma competência, não sei dizer isso.

Facilitadora diz: você não sente necessidade de desenvolver outras competências?

Estrelitza diz: eu acho que sou boa professora, curto o que faço, adoro dar aula, mas eu não sinto formalismo nisso. Ele não se deu de forma formal, mas também não se deu de forma anárquica. Não foi!!

Violeta pergunta: então, mas é no futuro?

Estrelitza responde: no futuro..., olha vocês me desculpem falar, mas meu futuro é um futuro muito próximo. O futuro próximo, não sei, eu gosto disso aqui gente \{aponta para a trajetória\}. Eu tenho dificuldade de me desligar, acho que eu vou empurrando um pouco mais. Sabe o que acontece? Eu acho que tudo isso aqui é muito bom, até no presente. Nós produzimos coisas muito importantes, muito além do nosso tempo \{choro\}. Nós estávamos à frente da nossa época. Então, isso \{apontando para a trajetória\} é presente. Quando as pessoas estão pensando no presente Falo: gente, mas isso a gente já pensava lá atrás! A Miosótis já pinicava a gente, a gente já pensava isso. Eu olho e falo: meu Deus! Está tudo tão atual, esse passado e é isso que eu quero \{indicando as representações nas cartolinas\}. Porque o presente que se coloca aí, não é o presente que eu quero, não é o futuro que eu quero, sem perder isso aqui \{novamente indicando as cartolinas\}. Nós produzimos muito, é uma sensação que eu tenho.

Violeta intervém: não é sensação, é real, você não lembra da tese da Cris, o que foi falado na banca pelo povo da Unicamp? O que foi desenvolvido aqui? É de arrepiar não é?

Facilitadora intervém: Estrelitza! Dá vontade de voltar?

Estrelitza responde: Não! Eu vou levando tudo isso aqui, sabe por que? Por exemplo a Miosótis. A Miosótis estava aqui, eu não peguei esse começo, eu peguei uma parte, convivi um bom tempo; mas eu vou pegar a Miosótis que está mais distante, longe do meu cotidiano; aí aparece a Miosótis aqui \{aponta para o presente, representado na cartolina\} essa Miosótis continua presente na minha vida, pelas coisas que ela produz, pelas influências, pelas marcas e pela história que ela fez na escola e na instituição, então, eu sinto que estou bem representada aqui. A minha docência é muito bem representada. Acho que eu me integro ... desse jeito, eu acredito nela desse jeito. Agora, é com isso aqui \{indica o passado\}, nesse passado que eu vivo o presente e que levo para o futuro.

Rosa diz: bom, eu quero colocar o meu e agora, eu vejo um pouco mais suave, agora bastante alegres \{referindo-se aos tecidos escolhidos para representar o futuro\}, mas, mais suave e eu dei uma separadinha aqui \{ainda referindo-se aos tecidos\} porque eu acho que continua cheio de possibilidades mesmo. Eu vejo até nessas possibilidades muitas coisas que eu posso desenvolver. O tom suave é na idéia mesmo de desafio de querer fazer de maneira mais tranqüila, mais suave, pelo amadurecimento, de perceber que não precisa ser muito turbilhão, que o amadurecimento vai assim...não é só o profissional, mas é também o pessoal e sinceramente eu não sei sabe? Estrelitza, quando você do futuro, quando você falou isso: meu futuro é muito próximo \{pausa, voz embargada de emoção, choro\} daí fiquei pensando assim...não sei se é um futuro daqui, da vida terrena, mas eu sei que ensinar enfermagem você pode ... cuidar, cui- 
dar de tantas coisas e eu sinto que estou caminhando para uma outra vida que não é aqui, embora eu sinto e sei que tenho muita coisa para fazer, até espiritual mesmo.

Miosótis diz: eu nem sei se vou colocar alguma coisa aqui, \{risos no grupo\} eu não consigo, cada vez que... eu percebi que não dá para pensar no futuro; o futuro? Eu caio no presente.

Estrelitza diz: a segurança está no meu passado. Isso aqui é a minha história e é com isso aqui que eu quero levar para o futuro que não sei...

Violeta interrompe e diz: então gente! Nós não estamos falando do nosso futuro! Cada um que colocou aqui, não está falando como competência, nós estamos falando da possibilidade de como usar essa competência e é isso que assusta, é esse futuro que a gente não tem certeza, se é longe se é perto, se é aqui ou acolá, é isso que assusta, porque a competência, ela está sempre sendo formada, ela não vai parar nunca.

Rosa intervém e diz: mas, que está vinculado a tudo isso que a gente viu aqui \{aponta para a representação nas cartolinas\}.

Violeta responde: sim, mas que assusta. Por que a gente assusta? Porque eu não sei quanto tempo eu tenho.

Estrelitza diz: gente, eu continuo com a segurança de que a coisa ta indo por causa disso aqui \{indica as cartolinas\}

Miosótis diz: engraçado! Eu não tenho medo do futuro, eu tenho medo do presente...

Violeta diz: eu não! O presente, eu estou lidando com ele.

Miosótis diz: exatamente, uma coisa que tem me martelado muito no presente, porque isso aqui \{refere-se à representação nas cartolinas\}, futuro, depende muito disso aqui \{refere-se ao presente\} e isso aqui \{futuro\} para mim, no meu caso, está turbulento, está caótico, ta confuso, aí, não dá para pensar só a docência porque eu não sou só a docência, eu sou inteira e a pessoa que eu sou e que foi acompanhando, marcando a minha docência não descolou. Evidentemente tem coisas que eu posso até quando aparece aqui, questões de técnicas, estratégias, não é nesse sentido acho; parece que o conceito que vocês querem montar, que foi falado, ela é construída na vida, nas relações, não nos cursos; os cursos é uma outra forma, auxilia, mas não resolve. Não que eu seja contrária percebe? Acho que aquelas saídas: dar tiro para todo lado, não faz das pessoas bons professores; os cursos, os certificados que eles dão pedagogicamente. A docência se resolve nessa construção \{indica as cartolinas\} de vida que é também saber pedagógico. No problema que acontece daqui para frente, é porque houve momentos em que...eu achava de forma atrevida que a gente podia mais do que pode, então, nessa fase para mim, de vida docente profissional que se aproxima de um desenvestimento como é chamado na literatura né? A fase de vocês é essa. Eu estou pensando, bom, como é que vai ser esse desenvolvimento, como é que você sai dessa cena, como é que você vai levar para o bastidor, mas não é assim...amargo. Como é que você vai olhar isso? O que é que eu preciso para olhar isso \{refere-se às cartolinas\}, sem me incomodar, daquilo que eu não consigo fazer, sabe? Perceber; esse foi o meu começo, porque eu vim primeiro. Agora o meu receio Miosótis, que está aqui comigo, está muito marcado pelo lugar onde eu trabalho; isso me incomoda.

Facilitadora intervém perguntando: a instituição?

Miosótis responde: sim esse lugar, a história é dessa instituição, mas a gente não conhece só ela, e a força como ela está impregnada aqui \{refere-se às cartolinas\} é muito forte e começa a influenciar na tua vida. É um negócio muito doido e esse é o medo, porque ele entrou um dia e lá \{aponta para o passado\} um dia aqui e acaba no presente. Tem uma frase muito marcante, acho que é do Rappa (grupo musical) é uma frase da música que fala isso: "paz, paz sem voz" é esse negócio de olhar neutro, então, é assim, pôxa!! Eu quis tanto paz, que qual é a paz que eu não quero conseguir, para tentar ser feliz. Então, acho, teve muita época \{aponta para as cartolinas\} que queria paz, agora ninguém quer mais paz. A minha paz hoje é à custa de um só pensamento. Eu não quero essa paz. Então, me fizeram nesse espaço senil entendeu? Eu não gosto muito. Eu quero romper \{indica as cartolinas, choro\} esse medo para seguir o futuro em paz entendeu?

Estrelitza diz: posso só falar uma coisa? Porque a Rosa falou da institucionalização e agora a Miosótis ta continuando, porque querendo ou não querendo, você está institucionalizada. Eu não sei se é um mecanismo pronto da gente, também não quero saber, mas, eu não consigo me descapturar. Não me libertar! Mas descapturar dessa institucionalização, que não aprisiona, porque você pode ser aprisionado, amarrado, amordaçado e tudo mais. Talvez porque a minha conjuntura de vida faça com que eu tenha outras linhas de escape, mas vamos pegar só na relação enfermeiro/docência aqui; quando eu falo que eu vou para a saúde pública aqui, que eu volto aqui \{indica as cartolinas\} aqui eu consigo me descapturar, eu acho. Agora, sofrimento? Tem claro! Mas tem linhas de fuga e sofrimento também porque o cenário aqui não é nada agradável também né? Mas aqui é...eu consigo fazer isso, talvez eu esteja me dando um tempo maior de sobrevivência nesta instituição. 
Rosa intervém: e eu fico pensando né? Estrelitza, que pode estar, porque por exemplo quando você está aí \{refere-se ao campo de estágio na saúde pública\} que é a hora que você pode estar na sala de aula, ou aí ou um outro espaço, numa relação muito boa, de independência, possivelmente de autonomia com o aluno,não nesse sentido "aluno", mas daquele que virá a ser, que vai ocupar os espaços futuros e que você tenha nesse amadurecimento nessas coisas que você já viu e aí eu concordo com você, é o grande momento que se dá a docência sabe? Porque aí você está mesmo lógico, ainda institucionalizado, mas talvez essa tua fala seja bastante expressiva; você consegue se descapturar.

Estrelitza diz: É verdade, eu me sinto mais professora quando estou atuando do que quando estou em sala de aula. Essa diferença de contextos, espaciais, territoriais, que para mim tem um significado também.

Rosa diz: Até por que você está numa relação com o aluno lá, numa coisa que é real, que é concreta, que você pode ou não, daí dependendo da sua ação, transformar.

Violeta diz: quando você estava falando isso (refere-se à Estrelitza) eu estava pensando exatamente isso, porque a hora que eu sinto meu melhor momento de docência com a competência docente, é esta fase, no corredor, sentada com o aluno fora daquela...do formal, porque a classe é aquela coisa meio teatral, com um monte de aluno em que um sai outro entra um presta atenção outro não, aquela coisa. Mas no momento em que você está com eles ali, meia dúzia de alunos, é outra coisa.

Estrelitza diz: Olha! Eu tenho uma coisa a declarar: vocês querendo ou não querendo, eu vou carregar vocês por um bom tempo (aponta para as cartolinas, risos no grupo). Eu sou...fortinha. Margarida diz: Bom, sabe o que eu queria falar agora? Eu vou colocar esse tecido longo aqui, rosa e azul, porque as coisas começam daqui (refere-se ao passado). Como a fala de todo mundo e eu acho que para o futuro tem que ter tranquilidade e persistir e para mim, sabe? Eu aprendi a ser docente com vocês entendeu? Apesar de estar longe da Miosótis, da Lírio, mas longe que eu digo, em unidades diferentes, mas vocês para mim são exemplos, então, eu estou me capacitando, mas...

Rosa intervém: Todas nós estamos nos capacitando (grupo muito emocionado)

Margarida diz: Então, não percam a esperança e nem a persistência, porque não é só do aluno que depende sabe? Vocês também são espelho para mim. Por isso coloco (refere-se ao retalho de tecido) muito longo, eu tenho que caminhar muito ainda, mas se eu tenho um mínimo de condição para estar aqui, é graças à vocês.

Rosa diz: Sabe, eu estou curiosa, até porque a Lírio é uma pessoas sempre muito observadora e eu confesso que estou incomodada e se você não se importasse eu te ouvir um pouco.

Lírio diz: Sabe o que é? Eu tenho uma admiração pelo Miosótis, que já é de muitos anos, e quando ela colocou essa coisa da paz sem voz, silenciosa, acho que mexeu comigo. Essa paz, esse medo, porque a gente acaba recolhendo um pouco, depois acabe conquistando de novo. Isso mexe muito comigo, porque eu acho Miosótis que você falou tão bonito (risos no grupo) porque eu acho que foi tão pertinente o que ela colocou, que a gente tem um pacto do silêncio, desse famoso pacto e eu acho que estou conseguindo superar esse pacto talvez pela própria atividade que estou vivendo agora e isso aí foi uma conquista, mas, mesmo assim como a Estrelitza fala, ainda esse pacto continua, eu não consigo separar esse medo, a instituição te aprisiona, te aprisiona, a gente não sabe como sair disso aí. Talvez na saúde pública você consiga se desvencilhar plenamente, mas esse medo ainda permanece e a gente vive parece, sempre a se permitir à essa pressão, à esse medo. Como que a gente consegue superar isso? (silêncio)

Facilitadora intervém: Como? Esta é uma pergunta que eu gostaria de fazer para o grupo, mas não necessariamente, ou exatamente de como superar o medo, mas que caminhos esse grupo pensa para encontrar prazer na docência, a readquirir segurança, as certezas, se isto é possível de alguma forma...

Lírio diz: acho que a probabilidade, a união, a integração ainda é para mim a fortaleza, porque se não houver união, quebra qualquer estratégia que a gente possa tentar. Se a gente conseguir manter uma integração com respeito, eu falo sempre das antigas né? (refere-se às docentes mais antigas) Agora você é antiga né? Margarida! Mas, as antigas eu acho que a gente possa caminhar um pouco, um pouquinho mais com esperança, porque a gente está muito desesperançosa...essa é a palavra, com medo de falar... com a Flor de Lis a gente teve um momento de paz e de repente novamente a gente está exposta a uma pessoa mais autoritária, então, acho que a gente só se firmaria com...união, respeito.

Violeta diz: Olha Lírio, eu sou nova aqui, então tem muitas coisas que vocês passaram aqui, que eu não passei. Eu acredito sim na união, mas não como uma forma de resultado, mas sim como uma forma de suportar o tempo, porque eu não vejo como mudar, eu não sei. 
Estrelitza diz:: Eu acho que o enfrentamento está se dando gente! De uma forma ele está se dando porque esse lance do Presente aqui também é muito forte. Hoje, qualquer gestor, seja ele mais medíocre ou mais aberto ou mais inteligente, que assumisse a direção da nossa escola, assumiria com tranqüilidade, porque nosso passado é muito forte e agente continua fazendo coisas muito importantes, no sentido de especialização, agora a residência, um trabalho que não é justo porque ele é sempre mais além, com compromisso. Acho que a primeira coisa é não ter vergonha desse passado; não é vergonha, é lembrar desse passado, não achar que é um passado e que a gente não cabe mais nele, que ele passou! Ele não passou, é muito presente nas nossas vidas por isso eu tenho a tendência de carregar, eu carrego o passado e carrego as pessoas junto. Acho que porque já nasci acompanhada, fui para a saúde pública, faço sindicalismo, eu acho que estou acostumada a essa coisa do coletivo, com muita facilidade, então, a primeira coisa é a seguinte: mesmo eu estando sozinha, porque esse passado aqui é um presente, com pessoas, com histórias e com idéias, então, as idéias estão presentes, então, não consigo ficar solitária, eu sempre acho que estou acompanhada e que uma hora aparece; eu não preciso estar com as pessoas, existe uma sintonia nesse grupo, é um grupo maior que não está aqui agora, também tem sintonia, então eu acho que a primeira coisa é essa, nós não seremos os primeiros a abandonar isso aqui. A outra coisa que é, uma forma de resistência, não poderia deixar de falar, a forma melhor de resistência é relembrar o passado. Uma delícia repetir como o passado era bom: - Mas isso nós já fizemos, isso é maravilhoso, isso a gente já fez como ninguém como ninguém fazia. Então, adoro, adoro torturar pelo passado. Adoro! Entendeu? Acho que essa é uma forma e a outra, gente, eu não sei se é empurrando o tempo, esperando o tempo passar, mas enfim, temos que caminhar.

Miosótis diz: Eu concordo com essa questão mesmo, como isso vai deixando marcas (aponta as cartolinas). Eu percebo que hoje as ações na transição do presente para o futuro, eu acho que só estou conseguindo agir no plano local, no individual, por enquanto entendeu? Acho assim, se eu trouxer isso aqui, (pega o tecido representado por ela no presente e coloca no futuro) em outro lugar, como diz a Violeta, eu quero continuar, ser no presente com olhar para o futuro, mas por hora eu só consigo fazer isso individualmente, neste momento, sabe? Vai ter outros laços para juntar, para estas questões individuais, mas por hora, uma coisa que me mantém, a minha esperança é nesse espaço (indica a representação do tecido dela) porque nele eu não tenho amargura, nele eu sou forte, só aqui (indica a representação do tecido dela) que é a sala de aula e a sala de aula a gente não vai entrar nos conceitos. Então, é nessa aposta que é como se eu dissesse: bom, eu tenho que construir outros laços, laços que vão... é a aposta que eu faço neles, neles eu aposto o futuro entendeu? Não é o que eu queria. Eu queria na linha mais que ela colocou (refere-se à margarida) vamos, vamos tudo junto, mas eu sinto aí um corte e só tenho assim, essa segurança de dizer: que bom que tenha uma ação local e, nessa ação local, que eu sou dona, tenho meu canto, que eu faço o que eu quero, falo o que quero, o que acredito e aqui eu sou a mudante e lá (refere-se ao passado) esse ninguém tira.

Rosa diz: Eu acho que pegando o caminho que a Lírio falou da união, muito do que a Estrelitza e o Miosótis acabou falando, eu acho que esses laços talvez eu usasse a expressão, porque eu ia usar a articulação, mas o laço, ele fica mais solidário. Acho que para criar esses laços, não existe forma ingênua; nós vamos ter que pensar em articulação que é de outra ordem, que é política. Política no sentido das relações e acho que até por conta desse desenvolvimento de competência política que parece importante não só para ter, mas como nesses espaços que você tem autonomia na sala de aula e tudo mais, que você consegue fazer. Agora, eu acho que até a gente não aprofundou, mas tentou iniciar uma reflexão de âmbito maior, de fazer eu acho que não é ingênuo, tem que ser político, mas ele tem que carregar essa coisa solidária, de estar fazendo, para você de fato fazer a transformação porque se você pegar o político, no meu entendimento, é só aplicar para fazer valer alguma coisa que a gente acredita, mas, se não for verdadeiramente solidário, a ponto de acreditar no outro e nas outras coisas, você também não vai conseguir transformar, a gente só vai viver períodos de menor possibilidade, daí eu fico imaginando, o que a gente fica esperando? Voltar a um período de possibilidade, tentar ajudar ou a gente pode ter ações e verdadeiramente tentar ajudar a transformar e transformar o outro mesmo porque eu não acho que o outro é impossível de ser transformado. Então eu vejo que não tem outro caminho, que é articulação mesmo, mas que não se dá, então, eu fico pensando nesses momentos, se a gente conseguisse, eu imagino né? Facilitadora, o sacrifício que foi conseguir reunir...meia dúzia de pessoas, mas eu fico imaginando, então, esse é um desafio grande porque também a instituição faz com que fiquemos muito separados, então, estas questões, elas não conseguem aparecer, eu mal encontro um chegando e outro saindo da sala...Para mim, o grande desafio hoje é você tentar buscar esta articulação, que não é ingênua, mas que tem quer ser solidária, se não você não transforma e, só vai dando uma maquiada e, quando vai ver ela está de volta, não tem jeito. 
Facilitadora: vocês acham que isso é possível, tentarmos esses encontros desta forma?!

Violeta diz: acho que é possível sim, muito possível, é uma questão de querer. Facilitadora, quando solicitado pra gente daqui a três horas, não ajunta todo mundo e faz!! Então porque não fazer esses encontros.

Rosa diz: a pergunta, não sei se é assim, se dá para fazer no aspecto de fazer. Acho que precisa haver outro significado, que é o desejo de se fazer este tipo de coisa, isso é uma coisa que pode iniciar um agrupamento, uma articulação, lógico aí vai ter acho, que efetivamente porque você não consegue, a gente não chora à toa, não sai chorando por aí. Então tem outra coisa que antecede, que é qual é a disposição das pessoas, porque mexe demais.

Facilitadora fala: que aparece muito nas entrevistas, uma questão da construção das competências coletivas e, como esse grupo vê essa possibilidade?

Estrelitza diz: eu fico pensando assim, em outros momentos como este, aqui, eu escolho as pessoas, porque eu não vou chorar para qualquer um. Eu acho talvez, que a gente pudesse pegar essa coisa da intencionalidade, porque não há ingenuidade eu acho, essa coisa você vai tocando aqui, não é tocar que nem barata tonta, tem uma intencionalidade nas coisas que a gente faz; se a gente quer recuperar a essência do passado, por exemplo, a gente pode reeditar as questões exatamente como foi, mas as idéias estão presentes como que intencionalmente ajuda na formação dessas outras pessoas, na construção coletiva dessa docência, que se dá na prática do cotidiano. Eu acho que talvez, usando de estratégias com temas e tudo mais, o coletivo pode facilitar, agrupando pessoas e criando essa cultura da gente fazer isso e ir pensando a docência, nossa prática e tudo mais. Agora, vou pedir um favor para vocês, eu não quero me reunir para expor todos os meus sentimentos para qualquer um.

Rosa: Então, talvez eu vejo a intencionalidade se ela começa, porque a construção coletiva, não acho que é isso agora de qualquer forma. Acho que pode ir começando em pequenos grupos, sendo desenvolvidos, que eles vão se fortalecendo e, logicamente que outros contatos existem que você vai fortalecendo os outros e é isso.

Facilitadora solicita que cada um possa encerrar sua fala, referindo uma expressão que signifique a experiência que o grupo vivenciou.

\{O grupo respondeu, paulatinamente, quase como sendo em ordem de posição à mesa, mas todas professoras concordando e realçando algumas falas:\}

ORGULHO, GRATIDÃO, ESPERANÇA, PERSISTÊNCIA, OUSADIA E CRESCIMENTO. 
ANEXO 10

TRATAMENTO DAS FALAS DO GRUPO FOCAL - 2 FASE 


\section{PASSADO}

1- Rosa encontra um tecido preto e diz: nossa! Tem até um preto aqui! Violeta responde: é...é o início de tudo!

2- Eu vejo que quando se começa a atividade docente, é tudo muito pequeno, você é pequena e com o tempo você vai crescendo, você vai construindo. É um fio só, é uma coisa que você vai trilhando, você vai juntando e vai evoluindo. Quando você inicia, esse caminho é muito estreito e com o tempo vai se abrindo, vai se alargando. No início é estreito e meio preto mesmo, você nem sabe para onde ir. Isto tem muito significado.

3- Violeta pergunta para o grupo se este seria o início da construção coletiva. Rosa responde: não dá para fechar, esta é uma idéia dela (Lírio) eu sugiro que cada um possa falar sobre o passado e fazer a representação com os retalhos. A não ser que este já seja um início.

4- Eu era uma garotinha tão bonitinha, tão dengosa, e quando eu comecei, eu tinha todas as possibilidades. Então, eu vejo assim com carinho, com a alma. Não havia problema, havia ingenuidade, havia eu comigo e meus desejos.

5-Começar a dar aula sempre foi o quê sempre quis, era o que me excitava profundamente, eu não tinha medo não! Eu queria fazer laços \{pausa\} fazer laços, não imaginava como. Era legal naquela época quando comecei aqui, porque acho que ninguém sabia direito como é que era.

6- Comparado com o início da Estrelitza que foi muito legal, mas o meu foi muito sofrido.

7- Para mim também foi muito bom poder iniciar e colocar em prática tudo aquilo que eu já acreditava e que vinha da minha experiência do hospital universitário. O passado é algo muito mesclado e muito colorido.

8- Quando me formei, eu tinha uma visão muito ampla, eu achava que tinha que buscar residência, buscar pós-graduação, especialização em obstetrícia, UTI, fui para Unicamp como aluna especial na enfermagem, na medicina, eu achava que tinha que saber tudo. Então foi um caminho de busca e que a contribuição foi importante, mas, você tem que afunilar isso e até entender isso, eu demorei muito.

9- Quando eu vim para cá, que era uma coisa que eu queria sim, era algo muito escuro, eu não sabia e nem queria repetir aquilo que vivi aqui. (refere-se ao momento como monitora) Então docência era assim, tem luz aqui, mas eu não enxergo, eu não estava preparada, não tinha embasamento para fazer aquilo que eu achava certo, não me sentia segura.

10- Eu também senti necessidade de buscar mestrado em Educação e era um momento de insegurança e muita angústia.

11- Eu estou ouvindo vocês falarem e gostaria de dizer que este rosinha que aponto aqui \{no laço feito no retalho\} é a minha identidade como enfermeira e não como docente. Eu cheguei aqui na Universidade como enfermeira.

12- Eu queria passar uma coisa de medo e até de vergonha, que foi quando dessa coisa minha, acabou sendo de ser a diretora \{da faculdade de enfermagem\}. Porque aí fui me dar conta de que eu podia saber para mim, me achava desafiada, podia errar, acertar, de achar que era um problema meu, dos alunos, eu não tinha a real dimensão. Aí, quando apareceu essa coisa de ter que estar falando, eu sentia vergonha, porque não me sentia preparada, me sentia muito mal e, eu descobri que na verdade, eu não sabia.

13- Naquele momento não era moda, não tinha uma exigência de capacitação, você aprendia fazendo, mas quando você passa

$\checkmark$ Trajetória profissional: algo "escuro", "pequeno", "estreito" possibilidade de crescimento construção, evolução; experiência anterior em hospital universitário; não estar preparada; necessidade de capacitação, desconhecimento do ser docente, busca de capacitação.

$\checkmark$ Características pessoais: parte do individual para o coletivo desejo de construir laços (relações interpessoais); vocação, sofrimento; passado é mesclado e colorido, insegurança, angús tia, ansiedade pela transformação da condição individual para a coletiva, medo, solidão.

$\checkmark$ Unidade de ensino: início genuíno, desconhecimento sobre a estrutura institucional, espaço para colocar em prática experiências já vivenciadas.

Construção de competências docentes: domínio de todo o conhecimento e habilidade; aprender-fazendo; 
a perceber \{pausa\} Nossa! E agora? Eu me sentia sozinha, perdida, eu tinha medo.

14- Apesar de tudo que passei, o caminho estreito, eu me achava o máximo. Até cair a minha ficha.

\section{PRESENTE}

15- Estrelitza \{se levanta vai em direção à cartolina do passado e a recoloca no centro da mesa, próxima à cartolina que representa o presente\} diz: olha eu carregando todo mundo aqui outra vez!

16- Violeta pergunta: porque você trouxe o passado de volta? Estrelitza responde: eu não consigo desvencilhar, olhar assim tão certinho até porque eu estou colada aqui.

17- Eu vejo que permaneço com essa coisa muito mesclada do passado até o presente, essa busca de aprimoramento, a oportunidade que surgiu aqui, apesar de todas as dificuldades, eu preciso encontrar o prazer, senão não estou na minha, e, no trabalho que a gente vive tanto tempo embora todos os empecilhos, pega todo o passado com percalços e tudo, mas eu sinto que não consigo perder essa mescla de busca e essa felicidade, senão não estava aqui, porque eu preciso dessa felicidade desse prazer pra viver mesmo; porque é assim que está acontecendo.

18- A gente está sempre mudando, é aquela coisa da busca é a busca do brilho é com esse brilho que a gente se mantém viva, porque é tanta coisa obscura, escura, tormento, então tem que ter um momento de sol também, mas de repente, eu vejo tudo muito carregado.

19- É um momento meio nebuloso, de muitos desafios.

20- eu continuo com a busca da capacitação, eu estou me capacitando, apesar de algumas inseguranças.

21- O azul (tecido que escolhe para representação do momento presente) representa tranqüilidade de perspectivas e o grupo se ajudando, se comunicando.

22- Acho que essa mistura (refere-se a uma mescla de tecido vermelho e preto), esse caos \{pausa\} tem coisa do passado, tem um olhar, mas misturado acho, que ainda tem um pouco dessa \{pausa\} o que é isto? Mas é interessante porque ao mesmo tempo eu acho que o presente me faz voltar à raiz das pessoas.

23- Eu coloco o azul também, porque para mim é tranqüilidade e os pontinhos pretos aqui em cima, são algumas dúvidas, algumas incertezas e acho que estarão sempre presentes, independentemente de estarmos sempre buscando, tentando, ousando e esses rosinhas \{referindo-se aos pedacinhos de tecidos recortados e sobreposto no tecido azul já com os tecidos pretos\}, são momentos de muita tranqüilidade, de certezas também de momentos legais.

24- Quando eu vou virando uma docente, eu vou virando com um pouco de cada uma \{aponta para o grupo\}, porque eu vou vendo e ouvindo a Miosótis como diretora empurrando a gente: vamos estudar, vamos, então eu fui aprendendo muito, com um, com outro. Esse grupo era muito forte e fui aprendendo. Hoje, no presente eu sou tudo isso aqui \{aponta para a cartolina\} porque eu gosto de ser o que as pessoas me ensinaram a passar a ser.

25- Eu não busquei uma capacitação formal. Hoje, não me acho a professora, nem quero mais ser o docinho. Eu utilizo dessa docência para defender a saúde pública, eu tenho uma relação muito clara com a minha docência, então eu continuo me sentindo..., por isso que estou presa aqui \{aponta para o passado na cartolina\} porque sou uma enfermeira de saúde pública e para fazer saúde pública eu uso a PUCC \{ênfase\}. Eu uso a PUCC para defender o SUS. Não estou interessada em ser reconhecida como a \{ênfase\} performance. Estou sendo super sincera gente, porque se não for sincera aqui não tem sentido. Acho que estou de bom tamanho para transmitir o que transmito.

26- Eu acho interessante porque atualmente eu me sinto cuidadora... é um conceito. $\checkmark$ Trajetória profissional: reconhecimento da influência do passado; aprendizado com o grupo; estar melhor hoje do que no passado; busca, possibilidade de mudança, busca de capacitação, influência das pessoas encontradas no passado; ser o que aprendeu com outras pessoas; a docência como identificação e atuação profissional; a capacitação específica ligada à docência; trabalho em equipe, coletividade.

Características pessoais: felicidade, prazer, obscuridade, tormento, nebulosidade, insegurança, dúvidas, tranquilidade, incertezas, certezas; ser cuidadora; ousar; resistência; persistência;

$\checkmark$ Unidade de ensino: a institucionalização do trabalho.

$\checkmark$ Construção de competências docentes: docente; ética; técnica; relacional; promover a transformação social; 
27- Nós somos docentes, estamos discutindo isto aqui e não dá para separar essas coisas. (refere-se à se docente ou enfermeiro).

28- Quando está se orientando o aluno aqui de enfermagem, essa coisa da enfermeira não tem como separar. Então, é como você falou \{referindo à Estrelitza\} que você usa a PUCC para fazer saúde pública, a gente está aqui fazendo transformação social, não é isso? E defendendo o cliente cirúrgico, defendendo o outro, cada um no seu espaço.

29- Não consigo colocar numa ordem de grandeza. Porque é um lócus meu, minha primeira escolha foi aqui \{aponta para o passado na cartolina\}. Então, eu fico imaginando que eu fui melhorando, eu estou melhor hoje de que quando cheguei, mas meIhorei por causa disso aqui \{aponta para toda a trajetória na cartolina\} e eu continuo aproveitando o que vocês produzem, do que vocês evoluem e, aí eu me incluo no bolo também. Não é uma coisa individualizada, entendeu? \{voz embargada pela emoção e choro\}. Então, não é que eu estou presa no passado, mas meu presente é tudo isso aqui \{novamente aponta para a trajetória na cartolina\}.

30- Quando você fez a pergunta facilitadora, da fala do Lírio, quer dizer, de onde vem essas incertezas, as angústias, eu acho que tem um fator muito importante que é a relação trabalho quando ele está institucionalizado e, nós todos somos institucionalizados. Aqui ou acolá e isto tem uma influência muito grande, você estar institucionalizado, porque assim, a vida acontece na relação com o trabalho e, você está dentro de uma instituição.

31- Até neste momento, em que o Lírio diz, desse ir e vir, ela está sendo influenciada no âmbito em que você convive, que é institucional, então, eu acho que até para você sobreviver aqui de maneira geral, embora tenha os momentos mais obscuros e de maior indefinição, predomina a idéia da clareza da vontade do querer, entendeu? Quer dizer, a gente quase que resistindo e, como a Margarida fala, essa coisa da persistência.

\section{FUTURO}

32- Eu vou continuar empurrando daqui \{apontando para o passado\}. Não sei se quero me desenvolver mais, não tenho clareza disso; tive alguns momentos formais que a instituição promoveu, você vai captando, mas não consegui me sentir... plena de competência. Não é isso, mas não sei se há alguma competência, não sei dizer isso.

33- Acho que sou boa professora, curto o que faço, adoro dar aula, mas eu não sinto formalismo nisso. Ele não se deu de forma formal, mas também não se deu de forma anárquica.

34- Futuro..., olha vocês me desculpem falar, mas meu futuro é um futuro muito próximo. O futuro próximo, não sei, eu gosto disso aqui gente \{aponta para a trajetória\}. Eu tenho dificuldade de me desligar, acho que eu vou empurrando um pouco mais. Sabe o que acontece? Eu acho que tudo isso aqui é muito bom, até no presente. Nós produzimos coisas muito importantes, muito além do nosso tempo. Nós estávamos a frente da nossa época. Então, isso \{apontando para a trajetória\} é presente. Quando as pessoas estão pensando no presente falo: gente, mas isso a gente já pensava lá atrás! O Miosótis já pinicava a gente, a gente já pensava isso. Eu olho e falo: meu Deus! Está tudo tão atual, esse passado e é isso que eu quero.

35- Porque o presente que se coloca aí, não é o presente que eu quero, não é o futuro que eu quero, sem perder isso aqui \{novamente indicando as cartolinas\}.

36- Eu vou levando tudo isso aqui, sabe por quê? Eu vou pegar a Miosótis que está mais distante, longe do meu cotidiano; aí aparece a Miosótis aqui \{aponta para o presente, representado na cartolina\} essa Miosótis continua presente na minha vida, pelas coisas que ela produz, pelas influências, pelas marcas e pela história que ela fez na escola e na instituição, então, eu sinto que estou bem representada aqui. A minha docência é muito bem representada. Acho que eu me integro... desse jeito, eu acredito nela desse jeito. Agora, é com isso aqui \{indica o passado\}, nesse passado que eu vivo o presente e que levo pa-

$\checkmark$ Trajetória profissional: Incertezas; influências do passado: no desenvolvimento do ser professor; no fortalecimento das relações interpessoais e do grupo de professores; na trajetória profissional e na maturidade profissional e pessoal; falta de investimento; construção da docência; autonomia docente independentemente da instituição; fortalecimento do grupo de professores e das relações interpessoais; comprometimento; individualidade; segurança.

$\checkmark$ Unidade de ensino: impotência; sentimentos de medo; sensação de aprisionamento, de 
ra o futuro.

37- Eu vejo um pouco mais suave, mas, mais suave porque eu acho que continua cheio de possibilidades. O tom suave é na idéia mesmo de desafio de querer fazer de maneira mais tranqüila, mais suave, pelo amadurecimento, de perceber que não precisa ser muito turbilhão, que o amadurecimento vai assim...não é só o profissional, mas é também o pessoal.

38- Eu nem sei se vou colocar alguma coisa aqui, eu não consigo, eu percebi que não dá para pensar no futuro; o futuro? Eu caio no presente.

39- A segurança está no meu passado. Isso aqui é a minha história e é com isso aqui que eu quero levar para o futuro.

40- Nós não estamos falando do nosso futuro! Cada um que colocou aqui, não está falando como competência, nós estamos falando da possibilidade de como usar essa competência e é isso que assusta, é esse futuro que a gente não tem certeza, se é longe se é perto, se é aqui ou acolá, é isso que assusta, porque a competência, ela está sempre sendo formada, ela não vai parar nunca.

41- Por que a gente assusta? Porque eu não sei quanto tempo eu tenho. (refere-se ao futuro).

42- Eu continuo com a segurança de que a coisa tá indo por causa disso aqui \{indica as cartolinas\}

43- Eu não tenho medo do futuro, eu tenho medo do presente...

44- O presente, eu estou lidando com ele.

45- uma coisa que tem me martelado muito no presente, porque isso aqui \{refere-se à representação nas cartolinas\}, futuro, depende muito disso aqui \{refere-se ao presente\} e isso aqui \{futuro\} para mim, no meu caso, está turbulento, está caótico, está confuso, aí, não dá para pensar só a docência porque eu não sou só a docência, eu sou inteira e a pessoa que eu sou e que foi acompanhando, marcando a minha docência, não descolou.

46- Parece que o conceito que vocês querem montar, que foi falado, ela é construída na vida, nas relações, não nos cursos; os cursos é uma outra forma, auxilia, mas não resolve.

47- Acho que aquelas saídas: dar tiro para todo lado, não faz das pessoas bons professores; os cursos, os certificados que eles dão pedagogicamente. A docência se resolve nessa construção \{indica as cartolinas\} de vida que é também saber pedagógico. No problema que acontece daqui para frente, é porque houve momentos em que...eu achava de forma atrevida que a gente podia mais do que pode, então, nessa fase para mim, de vida docente profissional que se aproxima de um desenvestimento.

48- Eu estou pensando, bom, como é que vai ser esse desenvolvimento, como é que você sai dessa cena, como é que você vai levar para o bastidor, mas não é assim...amargo. Como é que você vai olhar isso? O que é que eu preciso para olhar isso \{refere-se às cartolinas\}, sem me incomodar, daquilo que eu não consigo fazer, sabe? Perceber; esse foi o meu começo, porque eu vim primeiro. Agora o meu receio Miosótis, que está aqui comigo, está muito marcado pelo lugar onde eu trabalho; isso me incomoda.

49- Esse lugar, a história é dessa instituição, mas a gente não conhece só ela, e a força como ela está impregnada aqui \{referese às cartolinas\} é muito forte e começa a influenciar na tua vida. É um negócio muito doido e esse é o medo, porque ele entrou um dia lá \{aponta para o passado\}, um dia aqui e acaba no presente.

50- Me fizeram nesse espaço senil entendeu? Eu não gosto muito. Eu quero romper \{indica as cartolinas, choro\} esse medo para seguir o futuro em paz, entendeu?

51- querendo ou não querendo, você está institucionalizada. Eu não sei se é um mecanismo pronto da gente, também não quero dominação, de submissão; separação do grupo de docentes; incertezas; desafios.

$\checkmark$ Características pessoais: ter tranquilidade, persistência, esperança; união; integração; articulação política entre os docentes; desenvolvimento de competência política; acreditar no outro; exercer a solidariedade disposição, desejo de mudança; intencionalidade; envolvimento de docentes usando estratégias com temas específicos; não exposição de sentimentos junto ao grupo; desafio.

$\checkmark$ Construção de competências docentes: conhecimento; relacional; autonomia docente; política; educação permanente; reconhecimento da complexidade da competência; desenvolver a cultura da prática reflexiva. 
saber, mas, eu não consigo me descapturar. Não me libertar!, Mas descapturar dessa institucionalização, que não aprisiona, porque você pode ser aprisionado, amarrado, amordaçado e tudo mais. Talvez porque a minha conjuntura de vida faça com que eu tenha outras linhas de escape, mas vamos pegar só na relação enfermeiro/docência aqui; quando eu falo que eu vou para a saúde pública aqui, que eu volto aqui \{indica as cartolinas\} aqui eu consigo me descapturar, eu acho.

52- Quando você está aí é que é a hora que você pode estar na sala de aula, ou aí ou um outro espaço, numa relação muito boa, de independência, possivelmente de autonomia com o aluno, não nesse sentido "aluno", mas daquele que virá a ser, que vai ocupar os espaços futuros e que você tenha nesse amadurecimento, nessas coisas que você já viu, e aí eu concordo com você, é o grande momento que se dá a docência, você está ainda institucionalizado, mas talvez você consegue se descapturar.

53- Eu me sinto mais professora quando estou atuando do que quando estou em sala de aula. Essa diferença de contextos, espaciais, territoriais, que para mim tem um significado também.

54- Você está numa relação com o aluno lá (refere-se ao contado com o aluno), numa coisa que é real, que é concreta, que você pode ou não, daí dependendo da sua ação, transformar.

55- A hora que eu sinto meu melhor momento de docência com a competência docente, é esta fase, no corredor, sentada com o aluno fora daquela...do formal, porque a classe é aquela coisa meio teatral, com um monte de aluno em que um sai outro entra um presta atenção outro não, aquela coisa. Mas no momento em que você está com eles ali, meia dúzia de alunos, é outra coisa.

56- As coisas começam daqui \{refere-se ao passado\} como a fala de todo mundo e eu acho que para o futuro tem que ter tranquilidade e persistir.

57- Eu aprendi a ser docente com vocês entendeu? Apesar de estar longe da Miosótis, da Lírio, mas longe que eu digo, em unidades diferentes, mas vocês para mim são exemplos, eu estou me capacitando. Então, não percam a esperança e nem a persistência, porque não é só do aluno que depende sabe? Vocês também são espelho para mim.

58- Esse medo, porque a gente acaba recolhendo um pouco, depois acaba conquistando de novo. Isso mexe muito comigo, porque eu acho que a gente tem um pacto do silêncio, desse famoso pacto e eu acho que estou conseguindo superar esse pacto, talvez pela própria atividade que estou vivendo agora e isso aí foi uma conquista, mas, mesmo assim, ainda esse pacto continua, eu não consigo separar esse medo; a instituição te aprisiona, te aprisiona, a gente não sabe como sair disso aí. Mas esse medo ainda permanece e a gente vive, parece, sempre a se permitir a essa pressão, à esse medo. Como que a gente consegue superar isso?

59- Acho que a probabilidade, a união, a integração ainda é para mim a fortaleza, porque se não houver união, quebra qualquer estratégia que a gente possa tentar. Se a gente conseguir manter uma integração com respeito, eu falo sempre das antigas né? (refere-se às docentes mais antigas). Mas, as antigas eu acho que a gente possa caminhar um pouco, um pouquinho mais com esperança, porque a gente está muito desesperançosa... essa é a palavra, com medo de falar...

60- Com a Flor de Lis a gente teve um momento de paz e de repente novamente a gente está exposta a uma pessoa mais autoritária, então, acho que a gente só se firmaria com...união, respeito.

61- Eu sou nova aqui, então tem muitas coisas que vocês passaram aqui, que eu não passei. Eu acredito sim na união, mas não como uma forma de resultado, mas sim como uma forma de suportar o tempo, porque eu não vejo como mudar, eu não sei.

62- Eu acho que o enfrentamento está se dando gente! De uma forma ele está se dando porque esse lance do Presente aqui também é muito forte. Hoje, qualquer gestor, seja ele mais medíocre ou mais aberto ou mais inteligente, que assumisse a direção da nossa escola, assumiria com tranqüilidade, porque nosso passado é muito forte e a gente continua fazendo coisas muito importantes, no sentido de especialização, agora a residência, um trabalho que não é justo, porque ele é sempre mais 
além, com compromisso. Acho que a primeira coisa é não ter vergonha desse passado; não é vergonha, é lembrar desse passado, não achar que é um passado e que a gente não cabe mais nele, que ele passou! Ele não passou, é muito presente nas nossas vidas por isso eu tenho a tendência de carregar, eu carrego o passado e carrego as pessoas junto.

63- Mesmo eu estando sozinha, porque esse passado aqui é um presente, com pessoas, com histórias e com idéias, então, as idéias estão presentes, então, não consigo ficar solitária, eu sempre acho que estou acompanhada e que uma hora aparece; eu não preciso estar com as pessoas, existe uma sintonia e que esse grupo e um grupo maior que não está aqui agora, também tem sintonia, então eu acho que a primeira coisa é essa, nós não seremos os primeiros a abandonar isso aqui.

64- A outra coisa que é uma forma de resistência, não poderia deixar de falar, a forma melhor de resistência é relembrar o passado. Uma delícia repetir como o passado era bom: - Mas isso nós já fizemos, isso é maravilhoso, isso a gente já fez como ninguém como ninguém fazia. Então, adoro, adoro torturar pelo passado. Adoro! Entendeu?

65- Acho que essa é uma forma e a outra, gente, eu não sei se é empurrando o tempo, esperando o tempo passar, mas enfim, temos que caminhar.

66- Eu concordo com essa questão mesmo, como isso vai deixando marcas (aponta as cartolinas). Eu percebo que hoje as ações na transição do presente para o futuro, eu acho que só estou conseguindo agir no plano local, no individual, por enquanto entendeu? Acho assim, se eu trouxer isso aqui, (pega o tecido representado por ela no presente e coloca no futuro) em outro lugar, como diz a Violeta, eu quero continuar, ser no presente com olhar para o futuro, mas por hora eu só consigo fazer isso individualmente, neste momento, sabe?

67- Vai ter outros laços para juntar, para estas questões individuais, mas por hora, uma coisa que me mantém, a minha esperança é nesse espaço (indica a representação do tecido dela) porque nele eu não tenho amargura, nele eu sou forte, só aqui (indica a representação do tecido dela) que é a sala de aula.

68- Eu tenho que construir outros laços, laços que vão... é a aposta que eu faço neles, neles eu aposto o futuro entendeu?(refere-se aos alunos) Não é o que eu queria. Eu queria na linha mais que ela colocou (refere-se à Margarida) vamos, vamos tudo junto, mas eu sinto aí um corte e só tenho assim, essa segurança de dizer: que bom que tenha uma ação local e, nessa ação local, que eu sou dona, tenho meu canto, que eu faço o que eu quero, falo o que quero, o que acredito e aqui eu sou a mudante e lá (refere-se ao passado) esse ninguém tira.

69- Acho que pegando o caminho da união, acho que esses laços talvez eu usasse a expressão, porque eu ia usar a articulação, mas o laço, ele fica mais solidário. Acho que para criar esses laços, não existe forma ingênua; nós vamos ter que pensar em articulação que é de outra ordem, que é política. Política no sentido das relações e acho que até por conta desse desenvolvimento de competência política que parece importante não só para ter, mas como nesses espaços que você tem autonomia na sala de aula e tudo mais, que você consegue fazer.

70- Eu acho que a gente tentou iniciar uma reflexão de âmbito maior, de fazer eu acho que não é ingênuo, tem que ser político, mas ele tem que carregar essa coisa solidária, de estar fazendo, para você de fato fazer a transformação porque se você pegar o político, no meu entendimento, é só aplicar para fazer valer alguma coisa que a gente acredita, mas, se não for verdadeiramente solidário, a ponto de acreditar no outro e nas outras coisas, você também não vai conseguir transformar, a gente só vai viver períodos de menor possibilidade, daí eu fico imaginando, o que a gente fica esperando? Voltar a um período de possibilidade, tentar ajudar ou a gente pode ter ações e verdadeiramente tentar ajudar a transformar e transformar o outro mesmo, porque eu não acho que o outro é impossível de ser transformado.

71- Eu vejo que não tem outro caminho, que é articulação mesmo, esse é um desafio grande porque também a instituição faz com que fiquemos muito separados, então, estas questões, elas não conseguem aparecer, eu mal encontro um chegando e 
outro saindo da sala...

72- O grande desafio hoje é você tentar buscar esta articulação, que não é ingênua, mas que tem quer ser solidária, se não você não transforma e, só vai dando uma maquiada e, quando vai ver ela está de volta, não tem jeito.

73- Acho que é possível sim, muito possível, é uma questão de querer fazer esses encontros.

74- Não sei se é assim, se dá para fazer no aspecto de fazer. Acho que precisa haver outro significado, que é o desejo de se fazer este tipo de coisa, isso é uma coisa que pode iniciar um agrupamento, uma articulação, lógico aí vai ter, acho, que efetivamente porque você não consegue, a gente não chora à toa, não sai chorando por aí. Então tem outra coisa que antecede que é qual é a disposição das pessoas, porque mexe demais.

75- Eu fico pensando assim, em outros momentos como este, aqui, eu escolho as pessoas, porque eu não vou chorar para qualquer um. Eu acho, talvez, que a gente pudesse pegar essa coisa da intencionalidade, porque não há ingenuidade eu acho, essa coisa você vai tocando aqui, não é tocar que nem barata tonta, tem uma intencionalidade nas coisas que a gente faz; se a gente quer recuperar a essência do passado, por exemplo, a gente pode reeditar as questões exatamente como foi, mas as idéias estão presentes como que intencionalmente ajuda na formação dessas outras pessoas, na construção coletiva dessa docência, que se dá na prática do cotidiano.

76- Acho que talvez, usando de estratégias com temas e tudo mais, o coletivo pode facilitar, agrupando pessoas e criando essa cultura da gente fazer isso e ir pensando a docência, nossa prática e tudo mais.

77- Vou pedir um favor para vocês, eu não quero me reunir para expor todos os meus sentimentos para qualquer um.

78- Eu vejo a intencionalidade se ela começa, porque a construção coletiva, não acho que é isso agora de qualquer forma. Acho que pode ir começando em pequenos grupos, sendo desenvolvidos, que eles vão se fortalecendo e, logicamente que outros contatos existem que você vai fortalecendo os outros e é isso. 